\title{
PLANOS DE MANEJO INTEGRADO DE MICROBACIAS HIDROGRÁFICAS COM USO AGRÍCOLA: UMA ABORDAGEM HIDROLÓGICA NA BUSCA DA SUSTENTABILIDADE
}

\author{
ClÁUdia MiRA ATTANASIO
}

Tese apresentada à Escola Superior de Agricultura
"Luiz de Queiroz”, Universidade de São Paulo, para
obtenção do título de Doutor em Recursos Florestais,
com opção em Conservação de Ecossistemas
Florestais.

P I R A C I C A B A

Estado de São Paulo - Brasil

Agosto - 2004 


\section{PLANOS DE MANEJO INTEGRADO DE MICROBACIAS HIDROGRÁFICAS COM USO AGRÍCOLA: UMA ABORDAGEM HIDROLÓGICA NA BUSCA DA SUSTENTABILIDADE}

\section{ClÁUdia Mira ATtANASIO \\ Engenheiro Agrônomo}

Orientador: Prof. Dr. WALTER DE PAULA LIMA

Tese apresentada à Escola Superior de Agricultura
"Luiz de Queiroz”, Universidade de São Paulo, para
obtenção do título de Doutor em Recursos Florestais,
com opção em Conservação de Ecossistemas
Florestais.

P I R A C I C A B A

Estado de São Paulo - Brasil

Agosto - 2004 


\section{Dados Internacionais de Catalogação na Publicação (CIP) DIVISÃO DE BIBLIOTECA E DOCUMENTAÇÃO - ESALQ/USP}

Attanasio, Cláudia Mira

Planos de manejo integrado de microbacias hidrográficas com uso agrícola: uma abordagem hidrológica na busca da sustentabilidade / Cláudia Mira Attanasio. - -

Piracicaba, 2004.

193 p. : il.

Tese (doutorado) - - Escola Superior de Agricultura Luiz de Queiroz, 2004.

Bibliografia.

1. Agricultura sustentável 2. Bacia hidrográfica 3. Manejo integrado 4. Mata ciliar 5. Planejamento ambiental 6. Risco ambiental 7. Uso do solo I. Título

CDD 551.483

"Permitida a cópia total ou parcial deste documento, desde que citada a fonte - O autor" 


\section{Planeta Água}

Água que nasce na fonte serena do mundo

E que abre o profundo grotão

Água que faz inocente riacho e deságua

Na corrente do ribeirão

Águas escuras dos rios

Que levam a fertilidade ao sertão

Águas que banham aldeias

E matam a sede da população

Águas que caem das pedras

No véu das cascatas ronco de trovão

$\mathrm{E}$ depois dormem tranqüilas

No leito dos lagos, no leito dos lagos

Água dos igarapés onde Iara mãe d’ água

É misteriosa canção

Água que o sol evapora

Pro céu vai embora

Virar nuvens de algodão

Gotas de água da chuva

Alegre arco-íris sobre a plantação

Gotas de água da chuva

Tão triste são lágrimas na inundação

Águas que movem moinhos

São as mesmas águas

Que encharcam o chão

E sempre voltam humildes

Pro fundo da terra, pro fundo da terra

Terra planeta água...terra planeta água

Terra planeta água. (Guilherme Arantes)

Bendito sejais, ó Pai Providente, pelos rios e mares imensos,

pela bênção das chuvas, pelas fontes refrescantes

e pelas águas secretas do seio da terra” (Campanha da Fraternidade 2004 - CNBB).

Dedico

aos meus queridos pais Mario e Regina 


\section{AGRADECIMENTOS}

Ao Prof. Dr. Walter de Paula Lima, modelo de pesquisador brilhante, pela orientação, pela oportunidade de aprendizado e pela compreensão....muito obrigada!

À Maria José Brito Zakia (Zezé), pelas importantes contribuições e por me receber em sua casa quando cheguei em Piracicaba.

Ao melhor amigo e professor Sergius Gandolfi, pelo exemplo de pesquisador, professor, ser humano, pela generosidade, confiança, incentivo, companheirismo...minha eterna gratidão!

Aos queridos professores Ricardo Ribeiro Rodrigues, Oriowaldo Queda, José Teixeira Filho, pelo carinho, respeito, pelos ensinamentos e pelas contribuições valiosas.

Ao amigo José Carlos T. Veniziani Júnior, pela disposição em me ajudar a fazer as cartas temáticas deste trabalho usando Sistema de Informação Geográfica, pela solidariedade, gentileza e paciência infinita.

Aos meus companheiros catianos, João Brunelli, Maria Eugênia, Cristina, Dr. Martins e José Nildo, do Escritório de Defesa Agropecuária de Jaú, pela compreensão e pelo apoio fundamental na realização deste trabalho, e à outros que de alguma forma também muito me ajudaram, obrigada !

Ao grande pedólogo Hélio do Prado, pelo carinho, pela solidariedade e ajuda prestada na elaboração do mapa de solos da microbacia do Ribeirão São João, e ao Dr. Pedro Donzelli, por se disponibilizar a ajudar e a participar desta fase do trabalho.

Ao meu irmão Mario e minha cunhada Gabriela pela grande ajuda com as leis ambientais.

Aos funcionários da Casa da Agricultura de Mineiros do Tietê, Sandra e Seu Márcio, pelo fundamental apoio que possibilitou o desenvolvimento deste trabalho e pela amizade sincera. 
Ao querido Chico, do Departamento de Ciências Biológicas, por estar sempre pronto a ajudar.

Aos colegas do Laboratório de Hidrologia, Fernando, Carla e Paula, pela disposição e imprescindível colaboração.

Aos colegas Roberta, Luis e André (Cena) pelo auxilio no início do mapeamento.

Aos colegas de pós-graduação, Viviane, Noemi, Elisa, Lúcia, Marta, João Carlos, Cláudia (UNICAMP) e todos os outros, pelo convívio, alegrias e aprendizado compartilhados!

A amiga Maria Teresa Toniatto, pelos conselhos e pela constante disposição em ajudar.

Ao amigo Marcelo A. Silva, diretor de divisão da APTA- Regional Centro Oeste, pelo importante incentivo e colaboração.

Aos produtores rurais de Mineiros do Tietê, em especial da Microbacia do Ribeirão São João, pela inspiração, pela acolhida desde a minha chegada há 10 anos, pela rica experiência profissional e aprendizado da vida do campo que me proporcionaram e pela amizade que construímos juntos!

À UEL (Universidade Estadual de Londrina) e à ESALQ (USP) pela oportunidade de crescimento e de poder ver o mundo de forma diferente.

À CATI (SAA/SP) por me fazer íntima do meio rural e de minha própria profissão.

Àqueles que neste momento podem fugir à minha memória, mas que de alguma forma participaram do desenvolvimento deste trabalho, meu muito obrigada!

À minha família, meus irmãos, Mario e Marcos, e cunhadas, Gabriela e Lúcia, pela força e apoio e por nos darem o Marquinhos e a Mariana para alegrar a vida familiar.

Ao meu pai e a minha mãe, pelo amor incondicional, pela dedicação e esforço na formação de cada um dos filhos, com afeto, generosidade, pelo exemplo de dignidade, de luta e de postura diante da vida. Sem vocês eu jamais teria consegui chegar até aqui!!!

À natureza que ensina àqueles que a observam, o verdadeiro valor das coisas da vida...e deixa alegre o coração da gente.

A Deus, que me guia, me protege e me dá a vida! 


\section{SUMÁRIO}

Página

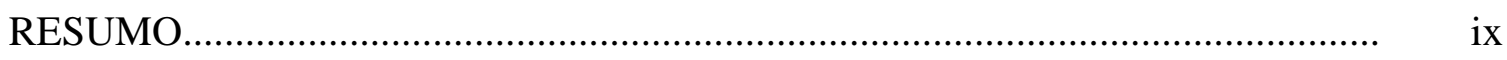

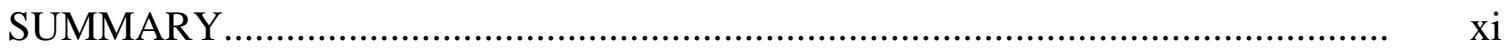

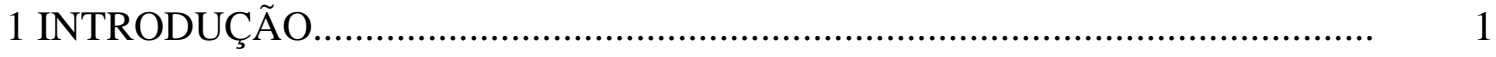

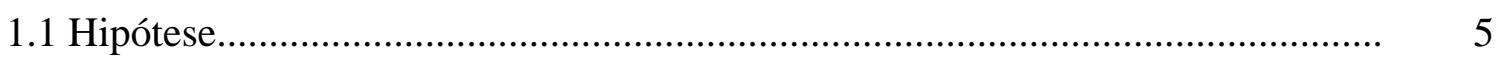

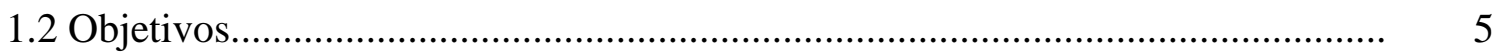

1.2.1 Objetivo geral....................................................................................... 5

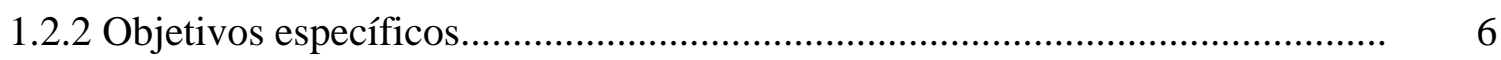

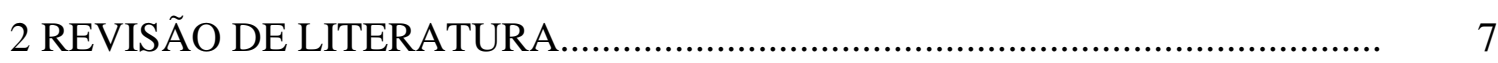

2.1 A agricultura sustentável.............................................................................. 7

2.2 A microbacia hidrográfica e os processos hidrológicos................................... 15

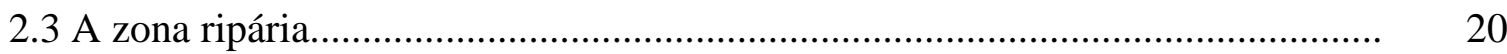

2.4 Monitoramento em microbacias hidrográficas................................................. 28

2.5 Construção de cenários e participação pública em planejamento ambiental........

2.6 Os programas de microbacias hidrográficas e a determinação dos riscos ambientais para o planejamento socioeconômico e ambiental da microbacia... $\quad 44$

2.7 O paradigma contemporâneo da ecologia......................................................... 49

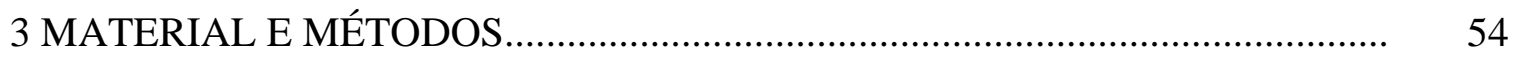

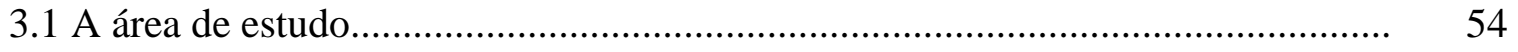

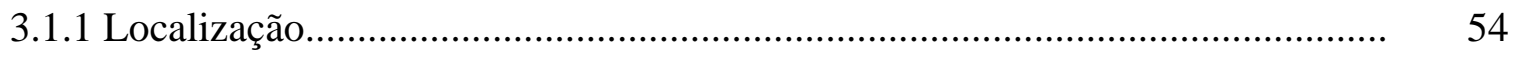

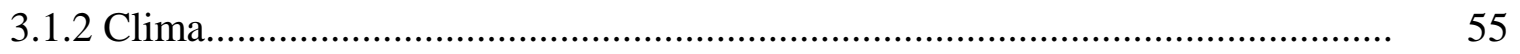

3.1.3 Caracterização socioeconômica, percepção da qualidade ambiental e manejo

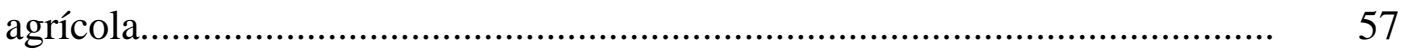

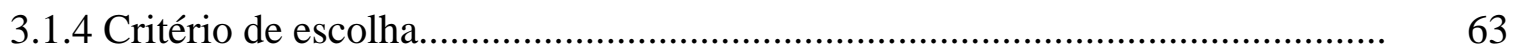




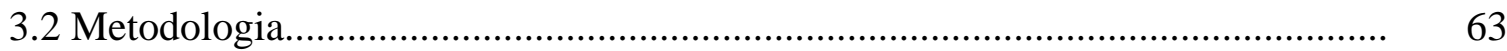

3.2.1 Base de dados descritivos dos aspectos agrícolas, ecológicos e socioeconômicos da microbacia do Ribeirão São João, necessários à composição dos cenários...................................................................................... 63

3.2.2 Integração dos dados para a composição dos cenários convencionais (sem inclusão da zona ripária) e alternativos (com inclusão da zona ripária) e comparação dos riscos estabelecidos a partir de cada cenário............................ 70

4 RESULTADOS E DISCUSSÃO.......................................................................

4.1 Base de dados descritivos dos aspectos agrícolas, ecológicos e socioeconômicos da microbacia do Ribeirão São João (Mineiros do Tietê, SP), necessários à composição dos cenários........................................................... 81

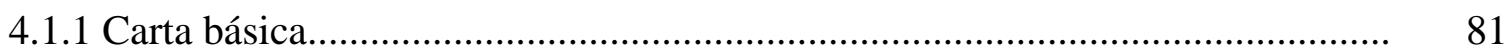

4.1.2 Tipos e associações de solos.............................................................................. 83

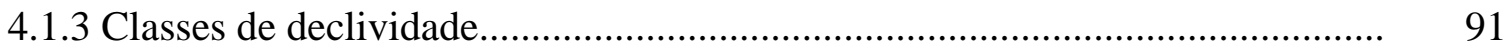

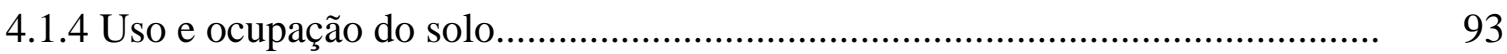

4.1.5 Vegetação e Áreas de Preservação Permanente.................................................. 96

4.1.6 Estrutura fundiária........................................................................................... 103

4.1.7 Diagnóstico e planejamento participativos....................................................... 104

4.2 Integração dos dados para a composição dos cenários convencionais (sem inclusão da zona ripária) e alternativos (com inclusão da zona ripária) e comparação dos riscos estabelecidos a partir de cada cenário

4.2.1 Composição dos cenários convencionais (sem inclusão da zona ripária)..........

4.2.2 Composição dos cenários alternativos (com inclusão da zona ripária).............. 126

4.3 Monitoramento sócio-ambiental da microbacia do Ribeirão São João.................. 162

4.3.1 Monitoramento da água..................................................................................... 163

4.3.2 Monitoramento do solo............................................................................. 166

4.3.3 Monitoramento da integridade da paisagem e da biodiversidade agroambiental............................................................................................. 171

4.3.4 Monitoramento socioeconômico........................................................................ 177

5 CONCLUSÕES..................................................................................... 180 


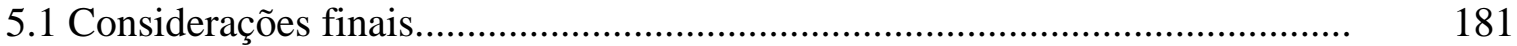

REFERÊNCIAS BIBLIOGRÁFICAS.............................................................. 184 


\title{
PLANOS DE MANEJO INTEGRADO DE MICROBACIAS HIDROGRÁFICAS COM USO AGRÍCOLA : UMA ABORDAGEM HIDROLÓGICA NA BUSCA DA SUSTENTABILIDADE
}

\author{
Autora: CLÁUDIA MIRA ATTANASIO \\ Orientador: Prof. Dr. WALTER DE PAULA LIMA
}

RESUMO

O objetivo deste trabalho foi comparar os cenários de inclusão e de não inclusão da delimitação da zona ripária da microbacia na determinação dos riscos ambientais, na adequação do uso do solo e conseqüentemente no planejamento sócio-ambiental, contribuindo com a elaboração e implementação dos planos de manejo integrado de microbacias com uso agrícola diversificado, considerando como premissas a busca da agricultura sustentável, a restauração do ecossistema ripário e o envolvimento social e econômico do produtor rural. Através de estudo de caso realizado na microbacia do Ribeirão São João (3.656 ha) no município de Mineiros do Tietê (SP), que faz parte do Programa Estadual de Microbacias Hidrográficas do Estado de São Paulo, foram feitas análises das suas condições sócio-ambientais que constaram de: a-) preparação de base cartográfica; b-) diagnóstico e planejamento participativos; c-) descrição de cenários convencionais e de cenários com inclusão da zona ripária para a adequação do uso do solo e caracterização dos riscos ambientais; d-) discussão sobre as relações entre o cenário que inclui a zona ripária e a legislação ambiental, a distribuição da estrutura fundiária, o uso e manejo agrícola e as estradas rurais e e-) proposta de um programa de 
monitoramento sócio-ambiental. O cenário com inclusão da zona ripária revelou que a microbacia possui 49,5 \% de sua área com uso adequado, 20,4 \% com sub utilização do solo e 1,9 \% com sobre utilização. Quanto aos riscos de erosão, 60,2 \% de sua área é considerada de baixo risco, 6,2 \% possui moderado risco e 5,4 \% compreende alto risco. Já o cenário convencional indicou que 59,0 \% da área estão ocupados com uso adequado, 28,2 \% com sub utilização, 2,6 \% com sobre utilização, 76, 9 \% da microbacia possui baixo risco de erosão, 11,0 \% moderado e 12,1 \% alto risco. Esta alteração induz o planejador a tomar medidas incompletas para a proteção das áreas que representam maiores riscos para a saúde da microbacia. Na microbacia estudada, 27,6 \% da zona ripária está inserida em Área de Preservação Permanente, portanto protegida pelas leis ambientais, e 72,2 \% estão sendo utilizados para agricultura, correndo risco de degradação. Em média, 26,1 \% das áreas das propriedades rurais da microbacia se encontram em zona ripária. Parte destas poderia ser protegida pela Área de Preservação Permanente e pelo estabelecimento das reservas legais. A porção da zona ripária que não estiver protegida pela legislação ambiental deveria ter um manejo diferenciado de acordo com seu uso. Em vários pontos as estradas rurais atravessam os rios e a zona ripária podendo ocorrer danos ambientais se medidas corretas de adequação de estradas não forem tomadas. O cenário alternativo proposto corresponde também aos principais anseios da comunidade da microbacia, isto é, a preservação dos recursos hídricos, detectados através do diagnóstico e planejamento participativos. Levando em conta as condições da microbacia, assim como evidências baseadas na revisão de literatura, a proposta inclui o monitoramento sócio-ambiental, compreendendo o monitoramento da água, do solo, da integridade da paisagem, da biodiversidade agroambiental e dos aspectos socioeconômicos. 


\title{
INTEGRATED WATERSHED MANAGEMENT PLANS: A HYDROLOGICAL APPROACH FOR SUSTAINABILITY
}

\author{
Author: CLÁUDIA MIRA ATTANASIO \\ Adviser: Prof. Dr. WALTER DE PAULA LIMA
}

\section{SUMMARY}

This work aims to compare the sceneries of including and not including the watershed riparian zone delimitation during the evaluation of the environmental risks in the land use planning, thus contributing for the implementation of integrated watershed management plans in the search of sustainable agriculture, based on the premises of riparian ecosystem restoration, as well as the direct participation of the land owners in the decision support process. A case study was developed in the São João creek Watershed, in the Municipality of Mineiros do Tiete, State of Sao Paulo. The case study included the preparation of the cartographic basis, diagnostic analysis and participative planning, description of conventional land use sceneries and alternative land use sceneries which include the delimitation of the watershed riparian zone, the comparison of the alternative sceneries in relation to the requirements of the Brazilian Forest Code in terms of stream buffer zone protection, as well as in relation to the watershed landownership structure, prevailing land use practices and rural roads design, and a proposition of an environmental monitoring program for the study watershed. The scenery that includes the riparian zone showed that $49,5 \%$ of the watershed total area has inadequate soil use, whereas $20,4 \%$ of the area with subutilization and $1,9 \%$ of the area with over-utilization. In terms of erosion risks, $60,2 \%$ of 
the watershed area can be considered with low erosion risk , 6,2\% has moderate risk and $5,4 \%$ with high risk of soil erosion. The conventional scenery indicated that $59 \%$ of the watershed area has inadequate land use, 28,2\% of the area is sub used, 2,6 \% of the land is over used, $76,9 \%$ of the land has low risk of erosion, $11 \%$ has moderated soil erosion risk and $12,1 \%$ of the total area has high risk of soil erosion. Around $27,6 \%$ of the riparian zone are located in the Forest Code stream protection area, and 72,2 \% of the area is prone to hydrological degradation due to inadequate land use practices. An average of $26,1 \%$ of the area of the watershed rural properties are located in the riparian zone. Part of this area should be protected according to the environmental law, or alternatively by the establishment of Legal Reserves. The portion of the riparian zone that is being used against the environmental law requirements should at least have a more conservative management approach. Rural roads cross the riparian zone in several locations and many of them cross the streams, which can pose hydrological risks. The proposed alternative scenery is in accordance with the main interests of the land owners, as detected in the participative planning, during which they raised concern about water resources conservation strategies. Considering the prevailing watershed conditions and also the information acquired in the literature survey, the study includes the monitoring of some water, soil, landscape integrity, biodiversity and socio-economic indicators. 


\section{INTRODUÇÃO}

Os sistemas convencionais de produção agropecuária são considerados grandes causadores de impactos ambientais, tais como, degradação do solo, poluição e assoreamento dos rios, destruição de vegetação nativa, perda de biodiversidade, e contaminação dos alimentos, o que conseqüentemente induz ao aparecimento de problemas sociais e econômicos.

Nos anos 80, a crescente preocupação com o meio ambiente e a qualidade de vida levou ao surgimento de um novo paradigma das sociedades modernas: a sustentabilidade.

Com o lançamento do Relatório Brundtland pela Comissão Mundial sobre o Meio Ambiente e Desenvolvimento em 1987, o ideal da sustentabilidade foi amplamente divulgado, surgindo, a partir de então, inúmeras definições para explicar o que se pode entender como agricultura sustentável. A maioria delas procura expressar a necessidade de estabelecimento de um novo padrão produtivo que não agrida o meio ambiente e que mantenha as características dos agroecossistemas (Ehlers, 1999).

Como ilustra o Plano de Ação do Banco Mundial "From Vision to Action in the Rural Sector” (Dumanski et al., 2000), há claramente uma demanda maior, a níveis nacional e global, para uma crescente produção e intensificação agrícola, mas o desafio é alcançar, conjuntamente, a manutenção da qualidade dos recursos naturais.

O termo agricultura sustentável passou a fazer parte das discussões relativas às atividades rurais e de quase todos os setores das sociedades. Entretanto, seu entendimento conceitual e operacional ainda não está claro (Quirino, 1999).

Mesmo diante de certas indefinições que este termo encerra, a inclusão da temática ambiental no contexto da produção agropecuária e tudo o que a ela se relaciona, 
como políticas públicas, planejamento do uso e manejo da terra, etc, é um avanço para a busca da sustentabilidade.

Segundo uma pesquisa realizada pela Embrapa, em que 135 especialistas foram consultados (Quirino, 1999), entre os métodos disponíveis de produção agropecuária há alguns que buscam a redução da degradação ambiental. Nos próximos dez anos, os mais importantes serão: a integração de diferentes sistemas de produção agrícola e pecuária com rotação de culturas e o manejo de microbacias hidrográficas.

A microbacia hidrográfica é a unidade básica de planejamento para a compatibilização da preservação dos recursos naturais e da produção agropecuária. As microbacias hidrográficas possuem características ecológicas, geomorfológicas e sociais integradoras, o que possibilita uma abordagem holística e participativa envolvendo estudos interdisciplinares para o estabelecimento de formas de desenvolvimento sustentável inerentes ao local ou região onde foram implementados.

Esta visão integrada, por parte dos planejadores, assim como dos produtores rurais, evidencia a lógica da interligação biofísica entre as ações desenvolvidas na microbacia e as reações do sistema. Por exemplo: alterações feitas por um agricultor nas práticas de manejo em determinadas áreas da microbacia, podem acarretar melhoria ou comprometimento da qualidade da água.

Para a manutenção da saúde ambiental de uma microbacia hidrográfica submetida à produção agrícola, as zonas ripárias, áreas saturadas da microbacia, encontradas tanto ao longo das margens da rede de drenagem, quanto em pontos mais elevados da encosta, exercem importante função do ponto de vista hidrológico, ecológico e geomorfológico.

O ecossistema ripário, que inclui a dinâmica da zona ripária, sua vegetação e suas interações, desempenha funções relacionadas à geração do escoamento direto em microbacia, à contribuição ao aumento da capacidade de armazenamento da água, à manutenção da qualidade da água na microbacia, através da filtragem superficial de sedimentos, e à retenção, pelo sistema radicular da mata ripária, de nutrientes liberados dos ecossistemas terrestres (efeito tampão), além de proporcionar estabilidade das margens, equilíbrio térmico da água e formação de corredores ecológicos. 
As florestas situadas em zonas ripárias são chamadas de matas ripárias.

As zonas ripárias são as áreas mais dinâmicas da paisagem, de direta interação entre o ecossistema terrestre e aquático (Gregory, 1991).

Todavia, estas áreas despertam interesses conflitantes. Por um lado, agricultores e pecuaristas a vêem com potencial produtivo ou como meio de acesso dos animais à água. Existem também interesses para a extração de areia, o corte seletivo de madeira, a mineração, a indústria, etc. Por outro lado, sua preservação e restauração, visando proteger suas funções hidrológicas, ecológicas e geomorfológicas, são essenciais na busca da sustentabilidade.

Mesmo diante do conhecimento atual sobre a importância da zona ripária e dos serviços ambientais que realiza, da constatação da degradação que estas áreas da microbacia vêm sofrendo e dos conflitos nela estabelecidos, a delimitação e o manejo sustentável da zona ripária não são considerados nos planejamentos agroambientais de microbacias hidrográficas realizados por governos estaduais, municipais e federal, além de outras entidades que também desenvolvem trabalhos em microbacias.

No Estado de São Paulo está sendo desenvolvido, desde 1997, o Programa Estadual de Microbacias Hidrográficas, proposto pela Secretaria de Agricultura e Abastecimento do Estado de São Paulo através de sua Coordenadoria de Assistência Técnica Integral (CATI), juntamente com o Banco Mundial, com o objetivo de promover o desenvolvimento rural do Estado visando a sustentabilidade socioeconômica e ambiental. Programa semelhante tem sido implementado a nível nacional e em vários Estados brasileiros (Santa Catarina, Paraná e Rio Grande do Sul), com grande efeito permanente e multiplicador no espaço.

Entretanto, mesmo tendo a microbacia como unidade de planejamento, estes programas não a consideram como unidade hidrológica ao não incorporarem os aspectos relacionados à zona ripária e ao deixarem de incluí-la como um instrumento do manejo sustentável.

Sendo a zona ripária fator essencial para a resiliência da microbacia, a estimativa dos riscos de degradação dos recursos naturais será, no mínimo, deficiente se não incorporar a manutenção da integridade do ecossistema ripário, comprometendo, desta 
maneira, um dos mais importantes serviços ambientais, a manutenção dos recursos hídricos, envolvendo a vazão, a qualidade da água, assim como do ecossistema aquático.

Para despertar a consciência sobre a importância da proteção e do gerenciamento da água doce no mundo e incentivar ações em nível internacional, nacional e regional em busca da sustentabilidade, a Conferência das Nações Unidas de 12 de dezembro de 2002 declarou 2003 o Ano Internacional da Água Doce. Assim também, a Conferência Nacional dos Bispos do Brasil (CNBB), ratificou como tema da Campanha da Fraternidade do ano de 2004, “Água, Fonte de Vida”, com o objetivo de trabalhar para garantir às gerações presentes e futuras o direito à água.

Para a avaliação dos resultados do plano de manejo sustentável do uso da terra e do alcance de seus objetivos pré-estabelecidos é imperativa a necessidade de implementação de um programa de monitoramento socioeconômico e ambiental para a microbacia.

Um agroecossistema, isto é, o local de produção agrícola visto como um ecossistema, pode ser dito sustentável se continua produtivo por um longo período de tempo, sem degradar as suas bases de recursos naturais. Mas quanto seria esse longo período, como determinar se houve degradação de recursos e como pode ser caracterizado um sistema sustentável se a prova da sustentabilidade está no futuro? Uma tarefa importante é identificar os parâmetros da sustentabilidade (características específicas dos agroecossistemas que constituam peças-chave em seu funcionamento) e determinar em que nível ou condição eles devem ser mantidos para que um funcionamento sustentável possa ocorrer (Gliessman, 2001).

Para tanto, a identificação de indicadores de sustentabilidade (condições específicas do agroecossistema necessárias para a sustentabilidade e indicadora dela) se torna fundamental.

Diante deste contexto e tendo como premissa a busca da sustentabilidade agrícola, o presente trabalho tem como objetivo apresentar uma proposta de inclusão dos aspectos relacionados à zona ripária, bem como de um programa de monitoramento na elaboração e implementação dos planos de manejo integrado de microbacias hidrográficas, por meio de um estudo de caso realizado na Microbacia Hidrográfica do 
Ribeirão São João (3.656 ha) no município de Mineiros do Tietê (SP), o qual faz parte do Programa Estadual de Microbacias Hidrográficas do Estado de São Paulo.

Para o alcance dos objetivos propostos, as análises desenvolvidas constaram da preparação de cartas temáticas referentes à caracterização agroambiental e hidrológica, do diagnóstico e planejamento participativos, da delimitação e avaliação, sob a ótica da hidrologia florestal, dos fragmentos florestais remanescentes da microbacia, das Áreas de Preservação Permanente e da zona ripária, assim como das relações desta com a legislação ambiental, a distribuição fundiária, o uso atual e o manejo agrícola e as condições das estradas rurais, relativamente à preservação dos valores ambientais da microbacia.

\subsection{Hipótese}

A inclusão do conceito de zona ripária na determinação da adequação do uso do solo e dos riscos de degradação ambiental em microbacias resulta numa caracterização diferente, relativamente ao que é observado nos métodos convencionalmente usados que não a consideram, acarretando diferenças no planejamento sócio-ambiental da microbacia.

\subsection{Objetivos}

\subsubsection{Objetivo geral}

Comparar a inclusão ou não da delimitação da zona ripária na determinação dos riscos ambientais, na adequação do uso do solo e conseqüentemente no planejamento sócio-ambiental da Microbacia Hidrográfica do Ribeirão São João no Município de Mineiros do Tietê (SP), uma microbacia com uso predominantemente agrícola onde está sendo desenvolvido um Plano de Manejo Integrado de Microbacias Hidrográficas vinculado ao Programa Estadual de Microbacias Hidrográficas da Secretaria de Agricultura e Abastecimento do Estado de São Paulo. 


\subsubsection{Objetivos específicos}

- Caracterizar os aspectos agrícolas, ecológicos, socioeconômicos da Microbacia Hidrográfica do Ribeirão São João (Mineiros do Tietê, S.P.).

- Descrever os cenários, convencionais e de inclusão da zona ripária, na determinação da adequação do uso do solo da microbacia.

- Caracterizar e comparar os riscos estabelecidos em cada cenário.

- Descrever as relações entre o cenário que inclui a zona ripária e a legislação ambiental (Áreas de Preservação Permanente, Reserva Legal), a distribuição da estrutura fundiária, o uso e manejo agrícola e as estradas rurais.

- Apresentar uma proposta, de planejamento ambiental com a intenção de proteger e recuperar o ecossistema ripário da microbacia.

- Propor um programa de monitoramento ambiental ao nível da microbacia, visando o manejo adaptativo. 


\section{REVISÃO DE LITERATURA}

\subsection{A agricultura sustentável}

Em escala global, a agricultura tem sido bem sucedida, satisfazendo uma demanda crescente de alimentos durante toda a última metade do século XX. O rendimento de grãos básicos aumentou, os preços dos alimentos caíram, a produção de alimentos, em geral, excedeu o crescimento populacional, e a fome crônica diminuiu em muitas regiões do mundo (Gliessman, 2001).

O aumento da produção de alimentos deveu-se principalmente ao desenvolvimento da pesquisa agropecuária e à introdução de um padrão produtivo, também chamado de "Revolução Verde”, gerado pela descoberta e uso dos fertilizantes químicos, dos agrotóxicos, do melhoramento genético e da motomecanização.

Entretanto, esse sistema de produção de alimentos está em um processo de minar a própria fundação sobre o qual foi construído, degradando os recursos naturais dos quais depende, representados pela degradação do solo, poluição da água e perda da biodiversidade, além de acarretar também graves problemas sociais (Gliessman, 2001) e econômicos.

Entretanto, como mostram os dados da Organização de Agricultura e Alimento das Nações Unidas - FAO (Gliessman, 2001), após apresentar uma tendência ascendente por muitos anos, a produção agrícola per capita estagnou nos anos 90.

Sob uma ótica global, nos países em desenvolvimento as pressões sobre os recursos naturais se originam no crescimento demográfico, no êxodo rural, nas mudanças dos hábitos de consumo. Na agricultura o uso das novas tecnologias para a produção é um fator determinante para o desenvolvimento econômico nestes países. Nos 
países desenvolvidos a agricultura intensiva, que leva a super-produção agrícola, está associada freqüentemente à contaminação e degradação do solo, da água e das florestas (El Bassam, 1999).

São muitas as maneiras, segundo Gliessman (2001), pelas quais a agricultura convencional afeta a produtividade ecológica futura, destacando-se:

- degradação do solo: pode envolver salinização, alagamento, compactação, contaminação por agrotóxico, declínio na qualidade da sua estrutura, perda da fertilidade e erosão;

- desperdício e uso exagerado de água: a agricultura é responsável por aproximadamente dois terços do uso global da água, sendo que em muitos locais não há nenhuma preocupação com o ecossistema aquático e ribeirinho e com a recarga dos aqüíferos;

- poluição do ambiente: a agricultura polui a água com agrotóxicos (inclusive herbicidas), fertilizantes (eutrofização) e sedimentos (assoreamento),

- a perda do controle local, pelas comunidades rurais, sobre a produção agrícola, provocada pela impossibilidade de reação da agricultura familiar frente a agricultura industrial,

- $\quad$ a dependência de insumos externo;

- a desigualdade global entre países desenvolvidos e países em desenvolvimento ou entre pequenos produtores rurais e grandes empresários;

- perda da diversidade genética: a base genética da maioria das principais plantas cultivadas torna-se cada vez mais uniforme, apenas 6 variedades de milho, por exemplo, são responsáveis por mais de 70\% da produção mundial de grãos.

Um problema grave da agricultura moderna é a perda da biodiversidade, que atinge formas extremas em monoculturas. A biodiversidade desempenha diversos serviços ecológicos nos sistemas agrícolas, sendo, portanto, fundamental a sua manutenção, restauração e seu incremento na paisagem agrícola. Dentre esses serviços estão, por exemplo, a reciclagem de nutrientes, o controle do microclima local, o controle dos processos hidrológicos, o controle da população dos organismos indesejáveis e a reversão de contaminação por substâncias químicas nocivas. Quando 
esses serviços ambientais são perdidos devido a uma simplificação biológica, os custos econômicos e ecológicos podem ser bastante significativos (Altieri, 2002).

Em sistemas complexos e diversificados, os produtores têm a sua disposição mais recursos para enfrentar os desafios que se apresentam, manejando apropriadamente seus componentes e interações, e conseqüentemente tornando a adição de insumos externos quase desnecessária. Por exemplo, as populações de pragas podem ser controladas por interações intencionalmente estimuladas do sistema (Gliessman, 2001).

Barbosa (2000) revela dados preocupantes de que 60 mil espécies vegetais, das cerca de 250 mil existentes no planeta, correm risco de extinção nos próximos 20 anos, devido à destruição de seus habitats. O processo de desmatamento nos trópicos, com a fragmentação das formações florestais, tem levado à extinção de muitas espécies vegetais e animais, apesar dos avanços nas leis que disciplinam a ação antrópica.

A degradação das formações vegetais, em especial as ciliares, não pode ser discutida sem considerar a sua inserção no contexto do uso e ocupação do solo, como fruto da expansão desordenada das fronteiras agrícolas (Rodrigues \& Gandolfi, 2000).

Nos anos 80, pesquisadores e produtores rurais, preocupados frente às evidências da degradação do meio ambiente e da ineficiência energética dos sistemas de produção, passaram a repensar as bases da agricultura, buscando caminhos para conciliar a preservação da natureza, a produção de alimentos e a viabilidade econômica. Além disso, houve aumento da pressão da sociedade sobre órgãos governamentais responsáveis pela inocuidade dos alimentos e pela defesa dos recursos naturais. Após a publicação, em 1987, do Relatório Brundtland, organismos internacionais como a ONU (através da FAO) e o Banco Mundial também apoiaram o novo ideal de sustentabilidade. Um grande número de definições sobre agricultura sustentável existe e todas elas incorporam os seguintes itens (Ehlers, 1999):

- manutenção a longo prazo dos recursos naturais e da produtividade agrícola;

- o mínimo de impactos adversos ao meio ambiente;

- retornos adequados aos produtores;

- otimização da produção das culturas com o mínimo de insumos químicos;

- $\quad$ satisfação das necessidades humanas de alimentos e de renda e 
- atendimento das necessidades sociais das famílias e das comunidades.

Em 1991, a FAO elaborou um documento chamado Declaração de Den Bosh, definindo agricultura sustentável: “O manejo e a conservação da base de recursos naturais e a orientação da mudança tecnológica e institucional, de maneira a assegurar a obtenção e a satisfação contínua das necessidades humanas para as gerações presentes e futuras. Tal desenvolvimento sustentável (na agricultura, no manejo florestal, na pesca, etc) deve resultar na conservação do solo, da água e dos recursos genéticos animais e vegetais, além de não degradar o ambiente, ser tecnicamente apropriado, economicamente viável e socialmente aceitável” (Quirino et al, 1999).

Diante de estudos sobre agricultura sustentável, Ehlers (1999) deixa claro que este novo paradigma está cercado por contradições e dúvidas. Para os mais conservadores bastariam simples ajustes no modo de produção convencional. Neste caso seria um objetivo de alcance a curto prazo. Para as tendências mais radicais, a agricultura sustentável requer mudanças mais profundas, transformações estruturais na economia, na sociedade e, passando pela pesquisa, pelos hábitos de consumo alimentar e pela revisão das relações entre os países desenvolvidos e em desenvolvimento.

Nesta mesma linha de críticas, Souza (1996), reforça o “caráter genérico e ambíguo do ponto de vista conceitual, que permite várias interpretações, servindo aos mais variados objetivos políticos-idiológicos”, além de destacar as dificuldades de operacionalização que as propostas de desenvolvimento sustentável encerra. Em seguida, refere-se às dificuldades de implementação das propostas de justiça social e desenvolvimento para as relações entre nações pobres e ricas.

O diálogo e a cooperação entre os países e comunidades, entre os diversos setores da economia, assim como, maiores investimentos em pesquisas, tecnologias e desenvolvimento são a base para superar um dos maiores desafios da humanidade que é garantir a sustentabilidade (El Bassam, 1999).

Para Souza (1996), as propostas referentes ao desenvolvimento sustentável, principalmente aquelas relacionadas à ordem mundial estabelecida, só serão implementadas quando ocorrer um debate político com a participação plena das populações organizadas e conscientizadas. Para este autor, mesmo com as polêmicas e 
críticas à respeito do conceito de desenvolvimento sustentável, houve um aumento da qualidade na concepção de desenvolvimento, quando se passou a incorporar as preocupações com ambiente, vinculando-as às questões sociais.

Pela primeira vez na história o manejo sustentável dos recursos naturais se mostra mais importante do que o suprimento de produtos para o desenvolvimento. Entretanto, a degradação ambiental e o manejo inadequado dos recursos naturais estão comprometendo as oportunidades e a flexibilidade para se potencializar os usos dos serviços ambientais, pois estão provocando crescimento nas necessidades de investimentos na conservação do solo e na reabilitação e restauração de áreas degradadas (Dumanski \& Pieri, 2000).

A sociedade deve redefinir suas expectativas e objetivos para que o manejo da terra possa alcançar a sustentabilidade ecológica e socioeconômica. Se a escolha for pelo manejo sustentável, então devemos aceitar restrições no manejo da terra (Montgomery et al.,1995).

Em resposta a uma visão unidimensional, Hurni (2000) enfatiza, também, no conceito de manejo sustentável, uma abordagem participativa dos vários grupos e categorias de pessoas que compartilham interesses na área em questão, uma avaliação do conhecimento local e uma pesquisa em várias escalas (Figura 1). Para este autor, é importante uma abordagem científica que combine a visão e percepção dos produtores rurais locais com o conhecimento dos pesquisadores, cientistas, administradores e políticos, isto é, que vá além da metodologia tradicional de interdisciplinariedade. Assim, ele propõe uma Avaliação de Desenvolvimento Sustentável cujo principal objetivo é abastecer um banco de dados a ser usado, através de um processo participativo, para promover o manejo e desenvolvimento sustentável. Esta metodologia envolve, como suporte, o monitoramento, a avaliação dos recursos, a experimentação, a informação e o treinamento. 


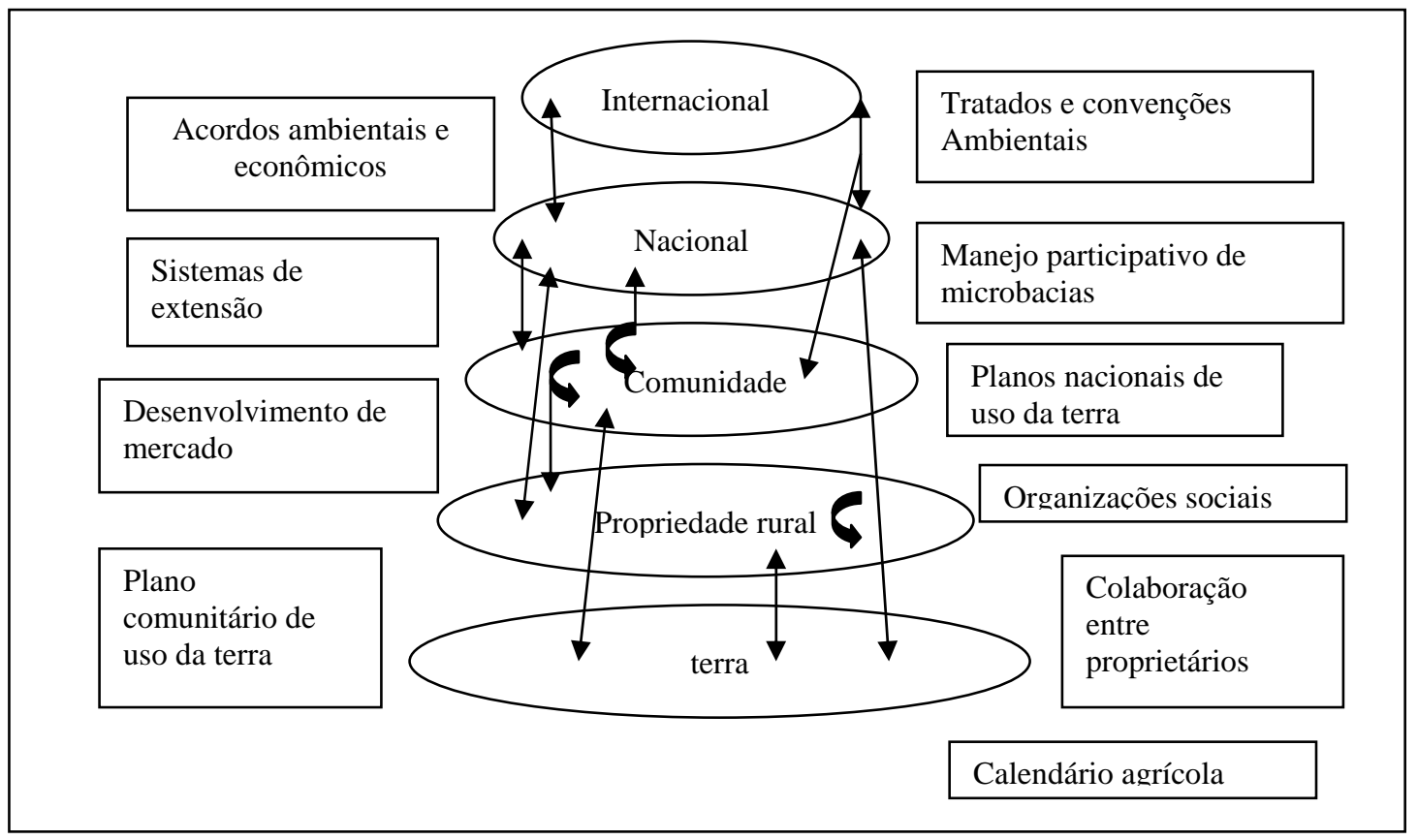

Figura 1 - Níveis de intervenções para um manejo sustentável (adaptado de Hurni, 1995)

A agricultura sustentável não constituirá um conjunto bem definido de práticas, como foi o chamado “pacote tecnológico” da Revolução Verde. Afinal, a interação com o meio ambiente e com a sociedade conduz à idéia de que cada agroecossistema tem diferentes características ambientais e sociais, exigindo, portanto, soluções específicas (Ehlers, 1999).

O agroecossistema é um local de produção agrícola (propriedade rural, por exemplo) compreendido como um ecossistema. Em análise aos aspectos estruturais dos ecossistemas (fatores bióticos, abióticos e relações mútuas) e aos seus aspectos funcionais (processos dinâmicos), os agroecossistemas são então descritos da mesma forma, em comparação aos ecossistemas naturais. A sustentabilidade pode ser considerada a qualidade emergente de uma abordagem ecossistêmica à agricultura (Gliessman, 2001).

Uma questão importante no desenho de agroecossistemas sustentáveis é a compreensão de que existem duas funções no ecossistema que devem estar presentes também na agricultura: a biodiversidade dos microrganismos, plantas e animais e a ciclagem biológica de nutrientes da matéria orgânica (Altieri, 2002). 
Gliessman (2001) sugere, para a identificação de elementos de sustentabilidade, estudos relacionados a ecossistemas naturais e agroecossistemas tradicionais. Os ecossistemas naturais possibilitam o entendimento dos fundamentos ecológicos da sustentabilidade; os agroecossistemas tradicionais guardam bons exemplos de práticas agrícolas realmente sustentáveis e da dinâmica dos componentes sociais (cultural, político e econômico) nos sistemas sustentáveis.

Segundo este autor, é impossível saber se determinada prática ou conjunto de práticas é realmente sustentável. Sendo a sustentabilidade aplicada ao conceito de produção sustentável, isto é, a condição de se colher biomassa perpetuamente de um sistema, considerando que sua capacidade de se renovar ou ser renovado não é comprometida, a prova da sustentabilidade permanece sempre no futuro. Contudo, é possível demonstrar que uma prática agrícola está se afastando da sustentabilidade.

Para Smith \& Thwaites (1998) é possível identificar, através do conhecimento científico ou tradicional do homem do campo, quais as práticas de manejo que ameaçam, a longo prazo, a produtividade agrícola e a integridade dos ecossistemas e assim evitálas.

E como saber se o atual manejo das terras está indo em direção à sustentabilidade?

A importância do desenvolvimento de programas para estabelecer indicadores de agricultura sustentável. A maior restrição, segundo ele, para o desenvolvimento e aplicação de indicadores de agricultura sustentável é a falta de base de dados satisfatório à nível nacional e global, levando ao requerimento de procedimentos de monitoramento para coletar esses dados, incluindo censo agrícola, sensoreamento remoto, pesquisas especiais e a combinação de todos eles. Indicadores são valiosos instrumentos para melhorar as decisões a serem tomadas, mas para serem realmente úteis devem estar inseridos dentro de programas que forneçam orientações diretas para políticas importantes (Dumanski \& Pieri, 2000).

É importante observar, diante destas considerações, que o conceito de sustentabilidade ainda encerra questões polêmicas e indefinidas, relacionadas à sua interpretação, metodologias de avaliação em situações concretas e a aplicação prática 
das propostas vinculadas a ele. Entretanto, o ganho com o estabelecimento desta discussão é inegável, pois apresenta a inclusão da temática referente ao ambiente, até então desconsiderada em políticas de desenvolvimento e pouco valorizada em planejamento convencional do uso da terra onde a capitalização da agricultura procura maximizar os lucros do capital, independente do impacto negativo sobre o meio ambiente.

A base teórica do presente trabalho de pesquisa está fundamentada neste conceito, que apesar de muitas vezes parecer utópico, representa o surgimento de um novo paradigma, uma nova visão do mundo, sistêmica, holística, balizadas em princípios de solidariedade entre nações e entre gerações, onde as propostas de desenvolvimento vêm acompanhadas da idéia de viabilidade ecológica e justiça social. Assim, mais importante do que apresentar definições genéricas do conceito, o que não será possível devido à grande diversidade que representa em diversos temas e locais, é produzir meios operacionais para sua implementação.

Segundo Ehlers (1999), um dos maiores desafios do século XXI será conciliar a segurança alimentar de uma população mundial, que em 2025 deverá atingir a casa dos 8,5 bilhões de habitantes, e a necessidade de conservar os recursos naturais, como exige o conceito de sustentabilidade. Para enfrentá-lo, será necessário unir o conhecimento científico da agricultura convencional ao conhecimento holístico da agroecologia. Em uma nova fase na história da dinâmica do uso da terra, o requerimento abusivo de insumos industriais e de energia fóssil deverá se substituído pelo emprego elevado de conhecimento ecológico.

Já se pode apontar alguns caminhos na busca da agricultura sustentável: estímulo à práticas que promovam a substituição das monoculturas por rotação e diversificação agropecuária, integração de sistemas agrícolas e pecuários, reorientação da pesquisa agropecuária para um enfoque mais sistêmico, a adoção de políticas públicas que promovam o fortalecimento e a expansão da agricultura familiar e manejo da produção com base em microbacias hidrográficas ( Ehlers, 1999; Quirino, 1999).

As microbacias hidrográficas são unidades espaciais e hidrológicas que possibilitam uma análise integrada dos recursos naturais, da produção agropecuária e do 
elemento humano, mais ainda quando o fator principal da análise é a água. Desta forma, o manejo integrado da microbacia pode ser um instrumento para a busca de uma agricultura sustentável.

\subsection{A microbacia hidrográfica e os processos hidrológicos}

O Brasil instituiu em 1934 o Código das Águas que, embora não tenha sido implementado de forma eficaz pela administração pública, representa um marco histórico no disciplinamento do uso e conservação de recursos hídricos, podendo ser considerado um dos primeiros e mais avançados instrumentos legais voltados ao gerenciamento da água no mundo moderno (Rocha et al., 2000).

Mais recentemente, a Lei Federal n 9.433/97 instituiu o Sistema Nacional de Gerenciamento de Recursos Hídricos, que elegeu a bacia hidrográfica como unidade territorial de atuação das políticas de recursos hídricos, planejamento e gerenciamento. Assim, a água passou a ser considerada um bem de domínio público, recurso natural limitado e dotado de valor econômico, que tem uso prioritário para consumo humano e dessedentação de animais em caso de escassez. Sua gestão deve proporcionar o uso múltiplo, ser descentralizada e participativa.

Com a Lei 9.984/2000, foi criada a Agência Nacional de Águas (ANA), e ampliada a composição do Sistema ao inseri-la no Sistema Nacional de Gerenciamento dos Recursos Hídricos, como entidade federal de implementação da política e de coordenação do Sistema.

O duplo domínio das águas levou os Estados a promulgarem suas respectivas políticas e a implantarem seus sistemas de gerenciamento de recursos hídricos, a partir do final de 1991. O Conselho Nacional de Recursos Hídricos aprovou a resolução 5/2.000, estabelecendo diretrizes para a formação e funcionamento dos Comitês de Bacia Hidrográfica, que constituem a base do sistema de gerenciamento, pois neles são promovidos os debates das questões relacionadas a recursos hídricos da bacia, articulada a atuação das entidades intervenientes e resolvidos, em primeira instância, os conflitos relacionados aos recursos hídricos (Thame, 2002). 
No caso específico do Estado de São Paulo, a Lei Estadual nº 7.663/91, anterior à Lei Federal, estabeleceu a Política e o Sistema Estadual de Gestão de Recursos Hídricos, instituindo a Política Estadual de Recursos Hídricos (PERH) e criando o Sistema Integrado de Gerenciamento de Recursos Hídricos. Entre os elementos básicos da PERH, que foram também implantados em nível federal, estão: o gerenciamento descentralizado e participativo, a cobrança pelo uso da água e a adoção da bacia hidrográfica como unidade de planejamento (Rocha et al., 2000).

A bacia hidrográfica é definida como uma compartimentação geográfica delimitada por divisores de água. Este compartimento é drenado superficialmente por um curso d’água principal e pelos respectivos afluentes (Fernandes, 1999).

Valente (1999) defende a bacia hidrográfica como unidade de planejamento por ser ela natural. Seus limites foram criados pelo próprio escoamento das águas sobre a superfície ao longo do tempo. É, portanto, resultado da interação entre a água e os outros recursos naturais.

Do ponto de vista hidrológico, as bacias hidrográficas podem ser classificadas em grandes e pequenas, não com base somente em sua superfície total, mas considerando os efeitos de certos fatores dominantes na geração do deflúvio. Em microbacias, devido sua grande sensibilidade tanto a chuvas de alta intensidade (curta duração) como também às diferenças de uso do solo, as alterações na quantidade e qualidade da água do deflúvio, são detectadas com muito mais facilidade do que em bacias grandes. Nestas últimas, o efeito do armazenamento das águas pluviais ao longo dos canais da rede de drenagem é tão pronunciado que a sensibilidade da bacia é menor aos fatores chuvas intensas e mudanças no uso do solo (Lima \& Zakia, 2000).

A microbacia constitui a manifestação bem definida de um sistema natural aberto e pode ser vista como a unidade ecossistêmica da paisagem, em termos da integração dos ciclos naturais de energia, de nutrientes e, principalmente, da água. Desta forma, ela apresenta uma condição singular e conveniente de definição espacial do ecossistema, dentro do qual é possível o estudo detalhado das interações entre o uso da terra e a quantidade e qualidade da água produzida pela microbacia (Lima, 1999). 
Estudos em microbacias fornecem metodologia para contribuir com a implementação do novo paradigma do manejo agrícola, que também pode ser chamado de manejo ecossistêmico. Para se implementar uma abordagem ecossistêmica nas tomadas de decisão sobre o uso e manejo da terra são necessários novos métodos que estabeleçam uma conexão entre a ciência e o planejamento. Essa integração é fundamental, pois para o uso sustentável dos recursos naturais é necessária uma conciliação entre os objetivos do manejo e a capacidade do ecossistema para responder a esses objetivos através do tempo. Para isso é importante identificar os impactos das ações humanas nos sistemas e processos ecológicos e, então, redefinir o manejo e uso da terra para minimizar esses impactos. Desse modo, são tratadas as causas e não apenas os impactos da degradação ambiental (Montgomery et al., 1995).

Segundo Black (1996) existem três objetivos gerais em manejo de microbacias hidrográficas:

1- reabilitação ou restauração de áreas alteradas, degradadas ou abandonadas, que produzem excesso de sedimentos, materiais poluentes, enxurradas, etc;

2- proteção de áreas sensíveis, o que pode significar a combinação de práticas de preservação com práticas de exploração buscando o desenvolvimento sustentável;

3- melhoramento das características dos recursos hídricos da microbacia através do manejo de uma ou mais elementos da microbacia que podem influenciar as funções hidrológicas ou de qualidade da água.

Esses três objetivos são apenas meios para classificar as metas do manejo. Na realidade uma dada prática pode se enquadrar em todas as metas ou em nenhuma, em diferentes locais e tempo.

Sendo a microbacia a unidade natural de planejamento do uso dos recursos naturais e considerando a água o agente unificador de integração no manejo de bacias hidrográficas, o conhecimento da hidrologia, bem como do funcionamento hidrológico da bacia hidrográfica, são fundamentais para o planejamento e manejo dos recursos naturais renováveis, visando o uso sustentável (Lima, 1996).

O ciclo hidrológico numa bacia hidrográfica envolve os seguintes processos: precipitação, evapotranspiração, deflúvio (precipitação nos canais, escoamento 
superficial, escoamento sub-superficial e escoamento base) e armazenamento de água no solo.

A quantidade de água produzida na microbacia (deflúvio) depende de sua área, enquanto que o regime de produção de água e a taxa de sedimentação estão sob a influência da forma e relevo da microbacia. A infiltração determina a fração da água de chuva que penetra no solo e consequentemente a que escoa superficialmente. A percolação é o movimento da água dentro do perfil do solo (Zakia, 1998). A água que infiltra e não retorna à superfície por evapotranspiração, percola até o aquífero.

Lima \& Zakia (2000) comentam que, desde os trabalhos pioneiros de Horton, publicados a partir de 1933, prevaleceu a teoria de que o escoamento direto era basicamente produzido pelo escoamento superficial que ocorre toda vez que a intensidade da chuva excede a capacidade de infiltração do solo, e que toda a água da chuva que se infiltra no terreno alimenta o lençol freático, para depois deixar a microbacia na forma de escoamento base. Mais ainda, segundo esta teoria o escoamento superficial assim gerado (hoje referido como escoamento superficial hortoniano) provinha de todas as partes da microbacia. Estes mesmos autores esclarecem, no entanto, que o modelo de Horton não funciona bem para quantificar o escoamento direto em microbacias florestadas de clima úmido, sendo mais adaptadas para microbacias do semi-árido, com solos rasos e desprovidos de vegetação. Em áreas com boas condições de cobertura vegetal, a ocorrência de escoamento superficial é rara ou mesmo ausente. Além disso, algumas áreas parciais da microbacia podem produzir escoamento superficial mesmo quando a intensidade da chuva é inferior à capacidade de infiltração. Estas áreas incluem:

- zonas saturadas que margeiam os cursos d’água e suas cabeceiras, as quais podem se expandir durante chuvas prolongadas (zonas ripárias);

- concavidades do terreno para as quais convergem as linhas de fluxo, como as concavidades freqüentemente existentes nas cabeceiras (também parte da zona ripária) e

- $\quad$ áreas de solo raso, com baixa capacidade de infiltração. 
Nas duas primeiras situações, o processo é denominado de “escoamento superficial de áreas saturadas”, o qual ocorre mesmo que a intensidade da chuva seja inferior à capacidade de infiltração do solo. Parte desse processo pode ocorrer na forma de interfluxo lateral e, portanto, não se trata de escoamento hortoniano. Na verdade, apenas parte da microbacia contribui, efetivamente, para o escoamento superficial de uma chuva. No início dos anos 60, o estudo de hidrogramas de microbacias florestadas experimentais permitiu o estabelecimento do conceito de "área variável de afluência” (A.V.A.) (Hewlett \& Hibbert, 1967).

O desenvolvimento desse conceito surgiu da constatação de que em microbacias com boa cobertura florestal o escoamento direto não é produzido ao longo de toda a superfície da microbacia. Pelo contrário, o escoamento direto, nestas condições, está sob a influência de uma área de origem dinâmica, uma vez que sofre expansões e contrações (daí o nome “área variável”), que comumente se constitui de uma fração pequena da área total da bacia, podendo variar de $1 \%$ a 50\%, dependendo da intensidade e quantidade da precipitação (Zakia, 1998).

Durante uma chuva, a área da microbacia que contribui para a formação do escoamento direto, é constituída dos terrenos que margeiam a rede de drenagem, pois nas porções mais altas da encosta a água da chuva tende principalmente a infiltrar-se e escoar até o canal mais próximo através do escoamento sub-superficial. Com o prolongamento das chuva estas áreas de origem tendem a se expandir, não apenas em decorrência da expansão da rede de drenagem, como também pelo fato de que as áreas críticas da microbacia, tais como áreas saturadas, áreas de solo mais raso etc, começam também a participar da geração do escoamento direto (Lima \& Zakia, 2000).

Assim o escoamento direto de uma chuva em microbacia com cobertura florestal, em condições de clima úmido é basicamente o resultado dos seguintes processos (Zakia, 1998):

- precipitação direta nos canais,

- escoamento superficial "hortoniano",

- escoamento superficial de áreas saturadas,

- escoamento sub-superficial e 
- expansão da área variável de afluência

Nas áreas saturadas da microbacia, tanto ao longo das margens da rede de drenagem, quanto nas cabeceiras e mesmo em manchas de áreas saturadas que podem ser encontradas até em locais mais elevados da encosta, o que prevalece é o escoamento superficial de áreas saturadas. Estas áreas ripárias desempenham, desta forma papel importante na resposta hidrológica da microbacia a um evento de chuva, e a vegetação ciliar a ela relacionada está intimamente vinculada com as condições do próprio curso d'água, numa cadeia de interrelações que tem sido denominada “ecossistema ripário” (Zakia, 1998).

Esta discussão sobre as questões hidrológicas relacionadas à microbacia permitem criar uma base teórica para a interpretação dos fenômenos e interações que nela ocorrem e fundamentar, desta forma, um plano de manejo que inclua entre suas prioridades a manutenção da zona ripária, objetivo central deste estudo.

\subsection{A zona ripária}

O primeiro nível de diagnóstico visando o estabelecimento de uma proposta sustentável de produção agrícola ao nível de microbacia hidrográfica seria a identificação destas zonas ripárias e a reconstrução dos serviços do ecossistema ripário.

Naiman et al. (1997), em uma ampla revisão bibliográfica, discutem as relações entre a zona ripária e os cursos d' água. Segundo esse trabalho, as interfaces entre sistemas ecológicos adjacentes possuem um conjunto de características próprias, isto é, atributos físicos e químicos, propriedades bióticas e fluxo de energia e de materiais definidos por uma escala de tempo e de espaço e pela forte interação entre esses sistemas.Essas interfaces podem ser comparadas a uma membrana semipermeável regulando o fluxo de energia entre os ambientes. As interfaces entre os ecossistemas terrestre e fluvial como, por exemplo, as florestas ripárias, as várzeas, as planícies de inundação, são particularmente sensíveis às mudanças ambientais. 
O fluxo lateral superficial da água nestas áreas é a força principal que organiza e regula as funções ripárias, incluindo o seu ciclo biogeoquímico e seu papel na paisagem, diferenciando os habitas ripários de outros (Malanson, 1995).

A zona ripária está localizada entre o nível mais baixo da água dos rios e o mais alto, e daí até as terras mais altas onde a vegetação ainda pode ser influenciada pela elevação do lençol freático ou pelas enchentes e pela capacidade do solo em reter água. Nas zonas ripárias, a variedade de distúrbios naturais cria um mosaico ambiental, do ponto de vista da escala de tempo e de espaço, com poucos paralelos em outros sistemas (Naiman et al., 1997).

Estas áreas são as mais dinâmicas da paisagem, tanto em termos hidrológicos, como ecológicos e geomorfológicos. As florestas que ocupam as zonas ripárias são chamadas de matas ripárias ou ciliares.

As funções hidrológicas do ecossistema ripário são, segundo Lima \& Zakia (2000):

- geração do escoamento direto em microbacia;

- contribuição ao aumento da capacidade de armazenamento da água na microbacia ao longo da zona ripária, contribuindo para o aumento da vazão na estação seca do ano;

- manutenção da qualidade da água na microbacia, através da filtragem superficial de sedimentos, diminuição significativa da concentração de herbicidas nos cursos d’água, retenção, pelo sistema radicular da mata ripária, de nutrientes liberados dos ecossistemas terrestres que chegam aos rios através de seu transporte em solução no escoamento sub superficial (efeito tampão).

A zona ripária desempenha o papel de controlar as fontes não pontuais de poluição por sedimentos e nutrientes nos cursos d’ água em microbacias agrícolas.

A zona ripária e o local principal para regulação e diminuição do transporte do nitrogênio inorgânico e do fósforo pelo escoamento subsuperficial para o rio. Sedimentos e poluentes transportados através do escoamento superficial são depositados na vegetação localizada nas margens dos rios (Naiman et al., 1997).

Para o manejo da zona ripária as características hidrológicas são as mais importantes. As zonas ripárias, funcionando como filtro, retêm poluentes presentes no 
escoamento superficial, devido sua capacidade de armazenamento e de infiltração. Elas interceptam o escoamento dominante da água que depende do tipo e permeabilidade do solo, uso da terra nas demais porções da microbacia, declividade, áreas com potencial de geração de runoff e sistemas de drenagem instalados. Para a remoção de nutrientes, como o nitrato, é necessário que a água se movimente superficialmente ou como escoamento subsuperficial passando pelas zonas biologicamente ativas do solo; já a remoção dos sedimentos requer que o escoamento superficial (runoff) não sobrecarregue a capacidade do sistema filtro da zona ripária. O crescimento da floresta ou a variação climática podem afetar o grau de saturação da zona ripária e a proximidade do lençol freático da superfície do solo, provocando alterações nesses processos de remoção (Naiman et al., 1997).

De acordo com dados experimentais citados por Naiman et al. (1997), as áreas ripárias removem 80-90 \% dos sedimentos oriundos das áreas agrícolas. Sedimentos finos carregam altas concentrações de nutrientes lábeis e poluentes adsorvidos e sua remoção pelo escoamento superficial ocorre em conseqüência de processos integrados de deposição e erosão, infiltração, diluição e adsorção/desorção reagindo com o solo florestal e a serrapilheira (Naiman et al., 1997).

Além dessa ação física de filtragem de nutrientes, as zonas ripárias podem também exercer uma filtragem biológica, através da captação de nutrientes pela floresta ou pela biota microbiana.

As florestas são importantes para interceptar e remover os nutrientes da zona ripária advindos das áreas agrícolas.

Elas o fazem pela acumulação desses nutrientes, através do aumento da transpiração, quando o fluxo de massa, para o sistema radicular, é estimulado ou através de adaptações morfológicas e fisiológicas de muitas espécies tolerantes a encharcamento, o que possibilita a captação de nutrientes sob baixa presença de oxigênio. Essa função da floresta ripária pode ser comprometida pela restrição das plantas ao acesso de água, pela variação, nas diferentes épocas do ano, da necessidade da planta, relacionada a sua fenologia, de captar e liberar nutrientes e pela diminuição da habilidade de seqüestrar nutrientes de florestas maduras. No que se refere à captação 
microbiana, o seu início se dá através do processo de imobilização de nutrientes dissolvidos, seguido pelo crescimento celular, morte, decomposição, e eventual liberação de nutrientes. O nitrogênio, que tem um caminho alternativo, e envolve outros processos, como a denitrificação, é o elemento mais importante para muitas florestas ripárias (Naiman et al.,1997).

Emmett et al. (1994) verificaram que a zona ripária ocupada com floresta reduziu em 38 \% a concentração de nitrogênio que chegou ao curso d’água, em 94 \% o fosfato e em 42 \% o fósforo dissolvido. Estes autores salientaram que a redução do nitrogênio foi um pouco abaixo do esperado, alertando para um limite na capacidade de imobilização deste elemento pela zona ripária.

Naiman et al. (1997), em análise a vários relatos experimentais, estimam a captação de nutrientes pela vegetação em 77 e $10 \mathrm{~kg} \mathrm{ha}^{-1}$ ano ${ }^{-1}$ de $\mathrm{N}$ e P, respectivamente. Potencialmente, as taxas de $\mathrm{N}$ podem ser maiores, como por exemplo, $213 \mathrm{~kg} \mathrm{~N} \mathrm{Na}^{-1}$ ano $^{-1}$ assimilados pelo Álamo (Populus nigra) quando fertilizados com efluentes ricos em nutrientes a uma taxa de $400 \mathrm{~kg} \mathrm{~N}$ ha $^{-1}$ ano ${ }^{-1}$ durante três anos.

A elaboração de planos de manejo adaptativo são necessários para enfrentar situações inesperadas relacionadas ao descontinuísmo ou ao sinergismo em zonas ripárias. O descontinuísmo em sistemas ripários ocorre quando a acumulação de nutrientes atinge um limiar e repentinamente transforma-se de deposito em fonte de poluentes. O sinergismo ocorre pelas interações entre dois tipos de stress crônicos (tais como carreamento de nutrientes e aquecimento global) ou entre um stress crônico e um agudo (como uma forte tempestade) (Naiman et al., 1997).

Um importante benefício econômico indireto das áreas ripárias é a manutenção da qualidade da água como um serviço ambiental. Benefícios econômicos diretos, tais como desenvolvimento de pecuária na zona ripária ou aproveitamento de madeira conflitam com as funções ecológicas destas áreas (Malanson, 1995).

A definição das áreas ripárias é um importante instrumento para manejo e monitoramento de microbacias hidrográficas. Também pode ser considerada mais um argumento forte para os produtores rurais, pois a manutenção das florestas estará sendo recomendada como prática de manejo mais adequada para determinados locais 
estabelecidos especificamente, para cumprir suas funções já descritas anteriormente. Além disso, servem como suporte para discussões sobre as bases técnicas da legislação e de políticas atuais.

O controle de fontes difusas de poluição pode apresentar melhores resultados se a poluição for controlada também pelo manejo agrícola adequado na microbacia. Essa associação de práticas agrícolas com a manutenção da zona ripária para a interceptação do escoamento subsuperficial pela vegetação em vários estágios da sucessão (que diferem na capacidade de absorção) é essencial para a manutenção, a longo prazo, da vitalidade da função de filtragem da zona ripária. As características do solo também influenciam a eficiência da zona ripária na filtragem de nutrientes e de agrotóxicos (Naiman et al., 1997).

Naiman et al. (1997) comenta que solos arenosos da zona ripária podem reter 32 \% do total de nitrogênio orgânico durante uma enchente, entretanto 70 \% pode ser retido em solos argilosos.

Outras funções importantes da mata ripária incluem (Lima, 1996):

- corredor ecológico;

- criação de microhabitats favoráveis para alguns organismos aquáticos;

- abastecimento do rio com material orgânico que serve de fonte nutricional à biota aquática;

- favorecimento do equilíbrio térmico da água em microbacia;

- estabilização da morfologia dos leitos dos rios.

Naiman et al. (1997) demonstram que as margens dos cursos d’água destituídos de vegetação são muito instáveis e sujeitas ao desbarrancamento, o que pode causar o assoreamento e alargamento do leito do rio em dezenas de metros anualmente. Os barrancos dos rios sem essa vegetação são 30 vezes mais susceptíveis à erosão do que aqueles vegetados.

Foi muito importante a mudança, em 1985, no texto do artigo $2^{\circ}$ do Código Florestal Brasileiro, que previa a largura mínima para matas ciliares de $5 \mathrm{~m}$ para cursos d’água de até 10 m de largura, passando para 30 m a largura mínima. 
$\mathrm{O}$ art. $2^{\circ}$ do Código Florestal Brasileiro, em seu caput, dispõe: “Consideram-se de preservação permanente, pelo só efeito desta lei, as florestas e demais formas de vegetação natural situadas:

a) Ao longo dos rios ou de qualquer curso d'água desde o seu nível mais alto em faixa marginal cuja largura mínima seja:

1- de $30 \mathrm{~m}$ (trinta metros) para os cursos d'água de menos de $10 \mathrm{~m}$ (dez metros) de largura;

2- de $50 \mathrm{~m}$ (cinqüenta metros) para os cursos d'água que tenham de 10 (dez) a 50 m (cinqüenta metros) de largura;

3- de $100 \mathrm{~m}$ (cem metros) para os cursos d'água que tenham de 50 (cinqüenta) a 200 m (duzentos metros) de largura;

4- de 200 m (duzentos metros) para os cursos d'água que tenham de 200 (duzentos) a 600 m (seiscentos metros) de largura;

5- de 500 m (quinhentos metros) para os cursos d'água que tenham largura superior a $600 \mathrm{~m}$ (seiscentos metros);

b) Ao redor das lagoas, lagos ou reservatórios d'água naturais ou artificiais;

c) Nas nascentes, ainda que intermitentes e nos chamados “olhos d'água", qualquer que seja a sua situação topográfica, num raio mínimo de $50 \mathrm{~m}$ (cinqüenta metros) de largura;

d) No topo dos morros, montes, montanhas e serras;

e) Nas encostas ou partes destas com declividade superior a $45^{\circ}$, equivalente a 100\% na linha de maior declive;

f) Nas restingas, como fixadoras de dunas ou estabilizadoras de mangues;

g) Nas bordas dos tabuleiros ou chapadas, a partir da linha de ruptura do relevo, em faixa nunca inferior a 100 m (cem metros) em projeções horizontais;

h) Em altitude superior a $1800 \mathrm{~m}$ (mil e oitocentos metros), qualquer que seja a vegetação.

Parágrafo único. No caso de áreas urbanas, assim entendidas as compreendidas nos perímetros urbanos definidos por lei municipal e nas regiões metropolitanas $e$ aglomerações urbanas, em todo o território abrangido, observar-se-á o disposto nos 
respectivos planos diretores e leis de uso do solo, respeitados os princípios e limite a que se refere este artigo".

Entretanto, o importante a considerar na definição da largura da faixa ripária é a manutenção do serviço ambiental realizado por ela, que por sua vez depende da manutenção da integridade do ecossistema ripário (Lima, 2003).

É conveniente deixar claro que as Áreas de Preservação Permanente estabelecidas pela legislação brasileira nem sempre correspondem às áreas ripárias da microbacia, que podem abranger trechos menos ou mais largos do que os 30 metros legais, ou ocupar áreas mais altas da microbacia como já mencionado. Em certas situações, a largura mínima estabelecida pela lei promove mais do que a proteção adequada, em outras não geram a proteção necessária.

Sparovek et al. (2002), em trabalho onde apresentaram uma metodologia para definição da largura ótima de florestas ripárias estimaram, através de Sistema de Informação geográfica (SIG), em estudo de caso desenvolvido em uma microbacia em Piracicaba (S.P), para a situação presente de uso atual do solo, tipos de solo e topografia, a largura ótima de 52 m, o que resultou em uma retenção de 54 \% do total de sedimentos produzidos.

Zakia (1998) identificou a zona ripária de uma microbacia de 62 ha em Arapoti (PR) através do modelo TOPMODEL e concluiu que esta ocupava 10,4 \% da microbacia e sua localização não era coincidente com a da mata ciliar estabelecida em lei.

A largura da zona ripária, a influência que a vegetação do canal tem sobre o ambiente do rio e a diversidade dos atributos funcionais (por exemplo, ciclos biogeoquímicos), são relacionados com o tamanho do rio, sua posição na rede de drenagem, o regime hidrológico e a geomorfologia do local (Naiman et al., 1997).

Nas condições ciliares, os fatores físicos do solo determinados diretamente pelo comportamento hidrológico local são os principais condicionantes da distribuição e composição de espécies, em contraste com os fatores químicos do sedimento que são determinados indiretamente pela dinâmica do rio (Rodrigues \& Shepherd, 2000). 
A estrutura, a dinâmica e a composição da vegetação ripária são influenciadas pelas complexas interações entre a hidrologia, a geomorfologia, a luz, a temperatura e o fogo característicos do local. A literatura sugere que a hidrologia e suas interações com a geologia é a mais importante delas (Naiman et al., 1997).

No contexto da paisagem regional, as formações ciliares estão sob condições muito específicas do ambiente, que acabam por diferenciá-las das formações do interflúvio. Muitas vezes essas diferenças se expressam apenas nos parâmetros quantitativos das populações e outras vezes até a fisionomia da vegetação é alterada (Rodrigues \& Nave, 2000).

Para o planejamento da restauração das florestas ripárias é necessário considerar todo o curso do rio para entender os vários aspectos da dinâmica da zona ripária, e assim restaurar a integridade do ecossistema dos rios e planícies de inundação. Onde essas áreas estiverem degradadas, com a vegetação removida, métodos existem para determinar o seu potencial de regeneração florestal (Naiman et al., 1997).

A delimitação da extensão das zonas ripárias, ecossistema extremamente dinâmico, complexo e com alta diversidade, é uma importante etapa para o planejamento das práticas de manejo integrado na microbacia. Este autor declara que para a proteção e restauração do ecossistema ripário, toda a sua integridade deve ser considerada, e não apenas alguns elementos isolados como, por exemplo, sua vegetação ou sua largura como previsto no Código Florestal. A zona ripária não apresenta limites simétricos e regulares ao longo da microbacia e a manutenção de sua integridade não será conseguida apenas pelo seu isolamento físico, mas vai depender da aplicação de práticas sustentáveis de manejo no seu entrono, ou seja, na escala da microbacia (Lima, 2002).

Montgomery et al. (1995) propõem um modelo para análise em microbacias baseado nas diferenças fundamentais entre as funções e os processos do ecossistema em áreas altas e em áreas baixas da microbacia, como por exemplo, aspectos relacionados a vegetação de locais sem influência fluvial e a vegetação ripária. Este modelo é baseado em uma abordagem guiada por questões relacionadas ao funcionamento dos ecossistemas, ao histórico dos impactos, às condições atuais da microbacia e às tendências de mudanças nos ecossistemas. A síntese das informações sobre a estrutura, a 
função, a dinâmica, o histórico, assim como as condições atuais do ecossistema e da microbacia, permite definir as áreas da microbacia e os elementos do ecossistema sensíveis à futuras alterações e identificar o potencial de resposta às atividades de manejo. Assim é possível estabelecer as condições futuras desejáveis e os passos necessários para alcançá-los.

Como visto, a floresta ripária ocupa as áreas mais sensíveis da microbacia, próximas aos cursos d’água, nascentes e áreas saturadas, desempenhando importantes funções como a filtragem superficial e subsuperficial do fluxo da água, a diminuição da ocorrência de escoamento superficial que pode causar erosão e carreamento de nutrientes e sedimentos, promovendo resultados visíveis na qualidade e quantidade da água do deflúvio. Entretanto, a presença da vegetação ciliar não é, por si só, em uma microbacia agrícola, garantia de proteção dos recursos hídricos e da zona ripária. Outras medidas integradas devem ser consideradas como aquelas relacionadas ao uso e manejo do solo, à adequação das estradas rurais, etc. para que não ocorra uma sobrecarga às florestas ciliares e assim a conseqüente degradação do ecossistema ripário.

É importante incluir a proteção e a manutenção da zona ripária, que envolve sua dinâmica e sua vegetação característica, no manejo de microbacias hidrográficas, que têm como objetivo a busca de uma agricultura sustentável, para em última instância, estabelecer a manutenção dos recursos naturais e, conseqüentemente, melhoria da qualidade de vida para a sociedade como um todo. Neste contexto, a implementação de um programa de monitoramento socioeconômico e ambiental, ao sinalizar as condições e tendências do ambiente causadas pelas atividades agrícolas, é indispensável na busca do manejo sustentável.

\subsection{Monitoramento em microbacias hidrográficas}

O monitoramento através de indicadores socioeconômicos e ambientais possibilita a contínua adequação do manejo agrícola, visando a manutenção da saúde da microbacia, fator chave da sustentabilidade. 
A noção de saúde da microbacia, um dos fundamentos do presente trabalho, é esclarecida por Walker et al. (1996). Segundo estes autores, saúde da microbacia implica numa condição viável, um estado sustentável compatível com o uso dos recursos naturais para a produção de bens demandados pela sociedade. Diferente do conceito de integridade da microbacia, que se refere a sua condição natural, decorrente dos processos evolutivos do ecossistema. Os valores sociais são parte da definição de saúde da microbacia e incluem a capacidade do sistema sustentar:

- a qualidade da água para uso doméstico e para armazenamento,

- a qualidade da água dos rios para preservar a biodiversidade e suas funções,

- a produtividade das terras para a manutenção da produção de alimentos e de sua viabilidade econômica,

- a biodiversidade para preservar as funções ecológicas dos ecossistemas,

- os valores estéticos da paisagem que contribuem para melhorar a qualidade de vida.

Uma microbacia saudável, embora submentida a uso intensivo, pode ainda se recuperar de perturbações naturais ou antrópicas (Walker et al., 1996).

Para se avaliar se as práticas agrícolas estão no caminho da sustentabilidade e se contribuirão para a manutenção da saúde da microbacia, é fundamental o desenvolvimento de um programa de monitoramento.

Um dos importantes aspectos relacionados a análises em microbacias é que ela possui limites bem definidos, permitindo entender as interações dos sistemas ecológicos e avaliar, através do monitoramento, se o plano de manejo do uso da terra está alcançando seus objetivos pré-estabelecidos. Estudos em microbacias possibilitam o estabelecimento das relações de causa e efeito entre as atividades de manejo e a degradação ambiental, considerando o fato de que, muitas vezes, a mesma ação quando implementada em vários pontos da microbacia pode resultar em impactos diferentes (Montgomery et al., 1995).

Monitorar os impactos da agricultura no meio ambiente é muito mais difícil que monitorar outros setores da sociedade. São muitos os proprietários rurais, pequenos e grandes, que usam os recursos da terra, e monitorar os impactos de suas decisões sobre 
uso da terra é um grande empreendimento. Embora individualmente os danos pareçam pequenos, vistos em escala regional e até global, os impactos ambientais advindos do manejo agrícola podem ter sérias conseqüências (Dumanski \& Pieri, 2000).

Para Montgomery et al. (1995), um plano de monitoramento de microbacias deve ter objetivos claros, ser baseado nas relações entre as mudanças observadas e os impactos esperados, ter uma estratégia de amostragem apropriada para detectar as mudanças, ter ferramentas para organizar, analisar, armazenar e restaurar dados do monitoramento, apresentar procedimentos para incorporação dos resultados do monitoramento em futuras tomadas de decisão e ser baseado em indicadores sensíveis das mudanças.

Um indicador pode ser uma variável mensurável, como por exemplo, a turbidez da água; um processo, como o balanço hídrico da microbacia; ou um conjunto complexo de variáveis múltiplas, um índice, incluindo inúmeras medidas tais como condutividade elétrica, sedimentos em suspensão, oxigênio dissolvido e outras.

Walker \& Reuter (1996) propuseram indicadores chave para a saúde da microbacia subdivididos e escolhidos de acordo com 11 critérios: facilidade para coletar dados, custo total / ha, disponibilidade de método padronizado para estimação, disponibilidade de critérios de interpretação, significância em escala da microbacia, baixo erro associado com a mensuração, reconhecível resposta ao impacto, estabilidade durante o período de mensuração, possibilidade de mapear, aplicação da informação de maneira genérica ou específica a respeito da saúde ambiental da microbacia e disponibilidade de dados.

Os indicadores de saúde da microbacia devem ter seus valores estabelecidos dentro de limites que representam o ponto no qual danos aos processos ecológicos podem ocorre ou, então, por níveis mínimos determinados pela comunidade local ou organizações governamentais. Os limites estabelecidos para os indicadores são geralmente baseados em conceito de condições “desejáveis”, como, por exemplo, os padrões de qualidade da água para consumo humano, e poucas vezes em amplos estudos ecológicos (Jones et al. ,1996). 
Para Walker et al. (1996) os indicadores para avaliação da saúde da microbacia são de dois tipos:

- indicadores de condição: são aqueles que definem o estado atual do sistema com relação a uma condição desejável;

- indicadores de tendências: são aqueles que medem como o sistema está mudando.

Para o uso desses indicadores é necessário considerar as informações tanto ao nível dos aspectos agrícolas pontuais (microescala) como ao nível da microbacia (mesoescala). Desta forma, estes autores sub-dividiram os indicadores de condição e de tendência em :

- indicadores da propriedade agrícola ou do agroecossistema: são aqueles relacionados principalmente aos atributos de saúde do solo. São úteis para mapear a distribuição espacial dos valores de cada atributo.

- indicadores de microbacia hidrográfica: são atributos que integram as respostas de toda a microbacia.Estes indicadores possibilitam uma resposta global ou dedução das respostas, entretanto não indicam a localização dos pontos mais sensíveis.

Diante do exposto, os aspectos de escala são importantes para o manejo sustentável. Lima (1999) esclarece que os processos que determinam a sustentabilidade operam em várias escalas e, assim, é importante haver diferentes indicadores para diferentes escalas. A microbacia constitui, neste aspecto, um elemento de escala especial, pelo fato de representar o elo entre a escala micro, correspondente às áreas onde são implementadas as práticas de manejo (propriedades rurais) e a escala macro, da paisagem, ou regional, ou nacional, onde são geradas as normas, a legislação e a política ambiental. Assim, a microbacia hidrográfica representa a escala do ecossistema para aferição tanto das imposições vindas da escala macro, quanto da implementação de práticas de manejo no campo, ou seja, na escala micro. Essa aferição é feita por meio de indicadores sistêmicos ou de processos do manejo sustentável.

No que se refere a escalas de análise da sustentabilidade, o agroecossistema representa a microescala. 
Análises em microbacias hidrográficas, isto é, de mesoescala, permitem avaliações específicas da paisagem e das interações entre seus recursos e processos físicos e biológicos. Em microescala fica difícil representar as relevantes conexões entre o que ocorre a montante e suas conseqüências a juzante na microbacia; por outro lado, numa macroescala, a interpretação e assimilação dos dados podem ser impraticáveis. As análises e decisões feitas em cada uma das escalas refletem informações e restrições herdadas de outros níveis da hierarquia. É fundamental conhecer as escalas temporais e espaciais sobre os quais os sistemas naturais operam, estabelecendo assim uma mudança no modo convencional de se planejar o uso da terra, baseado em unidades administrativas ou políticas, que desconsidera interações entre os seus elementos (ecológicos e humanos) e os seus processos (Montgomery et al., 1995).

A confirmação da sustentabilidade de um sistema está sempre no futuro. Para que seja possível prever se um determinado sistema pode, ou não, ser sustentável a longo prazo e desenhar agroecossistemas que tenham boas chances de se mostrarem sustentáveis é necessário conhecer os indicadores de sustentabilidade do sistema (Gliessman, 2001).

Os indicadores devem ser precisos e fiéis em descrever uma função específica do ambiente e devem servir para sinalizar as mudanças desejáveis ou indesejáveis que ocorrem ou podem ocorrer futuramente. Eles não podem ser entendidos com parâmetros ou variáveis para serem usados em modelagens, mas sim como atributos fundamentais que permitem a visualização das tendências e condições principais, e são baseados em componentes chaves do agroecossistema. Diferentes tipos de indicadores oferecem respostas para diferentes tipos de questões, em diferentes escalas e em diferentes níveis de complexidade (Walker et al., 1996).

Para Dumanski \& Pieri (2000), as características de indicadores para o monitoramento da agricultura sustentável incluem dentre outras:

- ser mensuráveis no espaço, isto é, ao longo da paisagem;

- refletir mudanças no tempo (5 a 10 anos);

- ser uma função de variáveis independentes e

- ser quantificáveis e muitas vezes adimensionais (estimativas de taxas). 
Vários pesquisadores têm trabalhado para categorizar os indicadores usados para o monitoramento ambiental. Uma das sugestões apresentadas por Walker et al. (1996) é a seguinte:

- indicadores de tendência: são aqueles que avaliam desvios com relação às condições previamente definidas ou aos limites aceitáveis.

- indicadores de diagnóstico: são aqueles que identificam a causa dos desvios com relação aos limites aceitáveis.

- indicadores de advertência: são aqueles que sinalizam um iminente declínio de determinadas condições.

Seguindo com a categorização de indicadores, estes mesmos autores apresentam uma subdivisão dos indicadores de tendência e de diagnóstico em três séries de especificidade baseadas em questões que orientam o monitoramento:

- série 1: Existem um problema?

- série 2: Que tipo de problema é este ?

- série 3: Qual é a causa específica deste problema?

Segundo Lima \& Zakia (1997) é consensual a possibilidade de se avaliar o uso, ou mau uso, da terra através do monitoramento de algumas propriedades da água superficial ou subsuperficial de uma microbacia. Os resultados de pesquisa de monitoramento ambiental de microbacias hidrográficas experimentais comprovam a eficiência do monitoramento de indicadores hidrológicos para se avaliar a saúde da microbacia, o que deixa claro a relação de causa e efeito entre os atributos (químicos, físicos e biológicos) e os impactos sobre a qualidade e quantidade (deflúvio) de água e o regime de vazão, sendo estes importantes indicadores para a análise da eficácia do manejo ambiental adotado na escala da microbacia (mesoescala da sustentabilidade). Para o planejamento de um programa de monitoramento é fundamental a identificação dos impactos sobre a qualidade da água decorrentes das atividades executadas na microbacia, o que permitirá uma correta seleção dos indicadores a serem monitorados e de sua periodicidade. 
Walmsley (2002) sugere em seu trabalho realizado na África do Sul uma estrutura que auxilia a identificação e o desenvolvimento de indicadores de sustentabilidade para manejo em microbacias. Neste contexto, o fator limitante é a água, portanto os indicadores estão relacionados aos recursos hídricos da microbacia. Esta estrutura é formada pelas seguintes categorias de indicadores:

1- Indicadores de força: refletem as condições naturais de uma microbacia (exemplo: clima) e o seu nível de desenvolvimento (exemplo:crescimento populacional, geração de efluentes e uso da terra);

2- Indicadores de pressão: refletem as pressões exercidas sobre os recursos hídricos de uma microbacia (exemplo: demanda ou poluição da água);

3- Indicadores de condição: avaliam o estado atual dos recursos hídricos no que se refere à qualidade e quantidade de água (exemplo: balanço hídrico, salinização, eutrofização e assoreamento);

4- Indicadores de impactos: incluem os principais impactos sobre a integridade do ecossistema (exemplo: diminuição da biodiversidade, perda da capacidade de resiliência, alteração do funcionamento do ecossistema, etc) e sobre o valor de uso da água (exemplo: aumento de ocorrência de doenças relacionadas à água, aumento dos custos da água, uso doméstico, recreação, restrição de água para o desenvolvimento econômico na agricultura, etc);

5- Indicadores de resposta: estão relacionados às respostas da sociedade através de políticas públicas, leis, programas, pesquisas, etc.

Esta estrutura identifica as relações de causa e efeito entre as categorias de indicadores para determinada microbacia, como mostra a Figura 2: 


\section{$\begin{array}{llll}\text { Forças } & \text { Pressão } & \text { Condição } & \text { Impactos }\end{array}$}

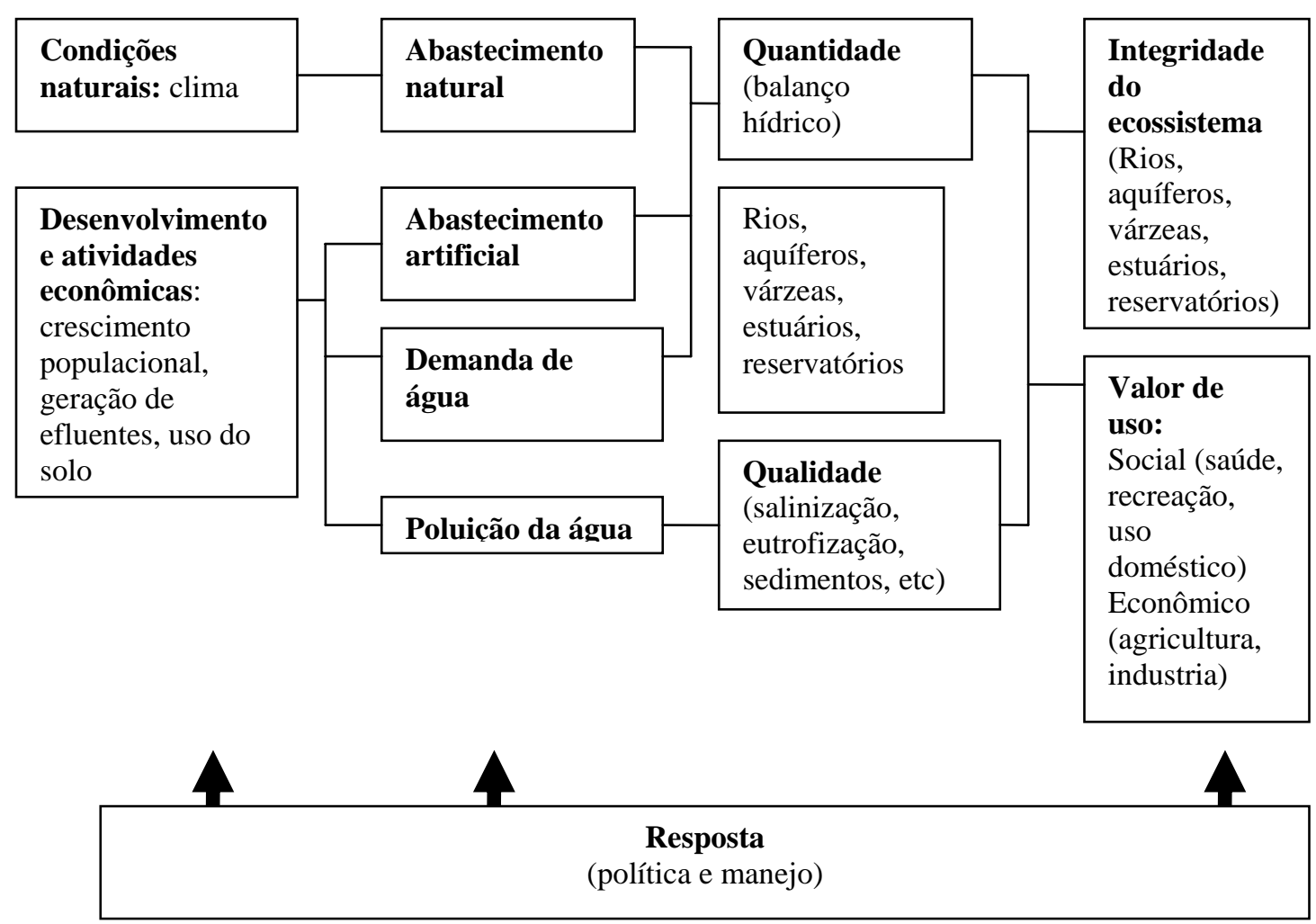

Figura 2 - Estrutura dos indicadores de sustentabilidade e as interrelações que ocorrem na escala da microbacia, considerando os recursos hídricos (Walmsley ,2002)

Os maiores problemas relacionados à qualidade da água são (Jolly et al., 1996):

- salinização: causada principalmente pela irrigação e solos descobertos. Pode afetar os rios, o solo e o lençol freático pela mobilização de sais, que ocorrem naturalmente no solo e nas camadas rochosas. Os principais indicadores sugeridos foram: condutividade elétrica da água, vazão, profundidade do lençol freático, consistência do solo e área descoberta.

- eutrofização: o aumento do nível de nutrientes nas águas dos rios causado pela descarga de esgoto, efluentes industriais e nutrientes vindos das áreas agrícolas (em 
especial o fósforo) provocam o aumento de algas tóxicas (cyanobactérias). Os indicadores propostos foram: concentração de fósforo e turbidez.

- turbidez: é causada pela erosão dos solos da microbacia, principalmente após uma chuva pesada, causando aumento de material em suspensão ou compostos solúveis, orgânicos e inorgânicos nas águas dos rios.Os indicadores sugeridos foram: medidas de turbidez, áreas com solos descobertos, consistência e uso da terra.

- poluição: ocorre pelo uso de agrotóxicos nas áreas agrícolas que são transportados pelas águas de irrigação ou das chuvas, podendo contaminar a água do solo ou diretamente os rios. Os indicadores propostos foram: consistência do solo e profundidade do lençol freático por serem de fácil mensuração.

- acidificação: a lixiviação e o escoamento superficial em solos ácidos reduzem o pH das águas superficiais ou subterrâneas. O indicador proposto é o pH.

- poluição biológica: resultado do lançamento de esgoto nos rios, podendo contaminar as pessoas através da prática de irrigação dos produtos agrícolas. O indicador proposto é a concentração de Coliformes fecais (E. coli).

As respostas da microbacia inteira se refletem no sistema aquático, pois os fluxos da água de uma microbacia fazem esta integração. Portanto as informações obtidas em um único local de monitoramento resumem toda a microbacia (Cranston et al.,1996).

Um programa de monitoramento sócio-ambiental para uma microbacia deve levar em consideração as interações que ocorrem dentro de seus limites e abordar os elementos, sociais e ambientais, que possuem esta relação de inter-dependência.

Segundo Cass et al. (1996), em trabalho sobre os indicadores para monitoramento do solo, a qualidade física do solo é importante para a saúde da microbacia devido à relação entre estas propriedades físicas e os processos hidrológicos na microbacia (infiltração, escoamento superficial, drenagem e erosão) e também por exercer um papel importante no suprimento e armazenamento de água, nutrientes e oxigênio para as plantas. As relações entre os processos hidrológicos e físicos são importantes para a produtividade agrícola, ou podem também resultar em degradação dos recursos naturais, através da erosão, salinização, acidificação e perda de nutrientes. 
Brown Jr. (2000) explica em seu trabalho sobre insetos indicadores da história, composição, diversidade e integridade de matas ciliares que os indicadores para monitoramento da riqueza e saúde dos sistemas ecológicos devem ser fiéis em acumular qualquer modificação de estrutura, diminuição de fluxo de matéria e energia, ou restrição de recursos, e rápidos em anunciar tendências de degradação, regeneração, ou recuperação de ambientes.

Neste caso, ele cita alguns grupos de insetos de grande mobilidade e ciclo curto de vida que, por serem elementos especializados da fauna, são importantes no reconhecimento, avaliação e monitoramento rápido e contínuo do complexo de microambientes e da heterogeneidade relacionada à fisionomia vegetal, solos, topografias e regimes hídricos das matas ciliares. Este trabalho é importante, pois o monitoramento da integridade das matas ciliares permite inferir sobre a saúde da microbacia.

Para Jones et al. (1996) é importante que os produtores rurais saibam o estado e as alterações dos componentes e padrões da paisagem, tanto em microescala, isto é, aquela associada diretamente aos seus interesses e problemas, quanto em mesoescala, a escala da microbacia. O que ocorre em determinada escala pode influenciar a outra. Por exemplo, os agricultores devem estar cientes do risco que representa os distúrbios na microbacia (enchentes, fogo, assoreamento, etc) na sustentabilidade das condições ambientais das quais a produção local depende. Por outro lado, as ações antrópicas na microbacia podem causar significantes alterações nos padrõres da paisagem e nos processos ecológicos, como por exemplo, distúrbios no regime de vazão dos rios da microbacia.

Segundo estes mesmos autores alguns indicadores da integridade da microbacia são mais úteis para estabelecer as condições e tendências da microbacia, outros são mais apropriados para diagnosticar as causas dessas condições. Nem todas as mudanças relevantes para o produtor rural ou para toda a comunidade da microbacia podem ser detectadas pelas alterações das características da paisagem. A poluição no rio, por exemplo, ou a introdução de espécies exóticas em substituição à espécies nativas podem causar pouca ou nenhuma mudança nos patrões e composição da paisagem. Por isso, 
para uma avaliação completa da microbacia o monitoramento da paisagem deve estar integrado aos indicadores da escala do agroecossistema, isto é, ao nível das propriedades e comunidades rurais.

Um programa recomendado por especialistas internacionais empenhados em selecionar indicadores de agricultura sustentável para uso nacional e internacional, mostra que indicadores robustos e confiáveis podem ser desenvolvidos através de ampla análise dos complexos sistemas a serem descritos e monitorados, que importantes questões de como integrar dados sócio-econômicos com informações biofísicas e de como agregar indicadores de nível local para escalas regionais, nacionais e globais devem ser consideradas. A qualidade ambiental deve ser avaliada pelos tipos de uso e manejo da terra e pelas condições das diferentes zonas agroecológicas ( unidade espacial para identificação e aplicação das opções de manejo, derivada das informações sócio econômicas e biofísicas geo-referenciadas ) de um país (Dumanski \& Pieri, 2000).

Walker et al. (1996) sugerem etapas para se alcançar o sucesso de um programa de monitoramento (Figura 3).

É importante realizar as análises dos indicadores não de maneira isolada, mas dentro do contexto do uso e manejo das terras em determinado local. Além dos indicadores de qualidade da água, o balanço de nutrientes, a intensidade e a diversidade do uso da terra, aspectos da cobertura vegetal e saúde do solo, a degradação do ambiente, podem também se constituir em bons indicadores.Atualmente, o manejo sustentável está comprometido pela falta de indicadores disponíveis para monitorar o modo como os produtores rurais estão manejando os recursos naturais, os impactos das políticas e programas relacionados ao manejo agrícola e os impactos dos diferentes cenários (relação entre causa e efeito) sobre a agricultura sustentável. Assim, pela falta de indicadores para monitorar as mudanças do uso da terra, as tomadas de decisões apropriadas sobre degradação ambiental, por exemplo, não possuem ainda uma orientação segura (Dumanski \& Pieri, 2000). 


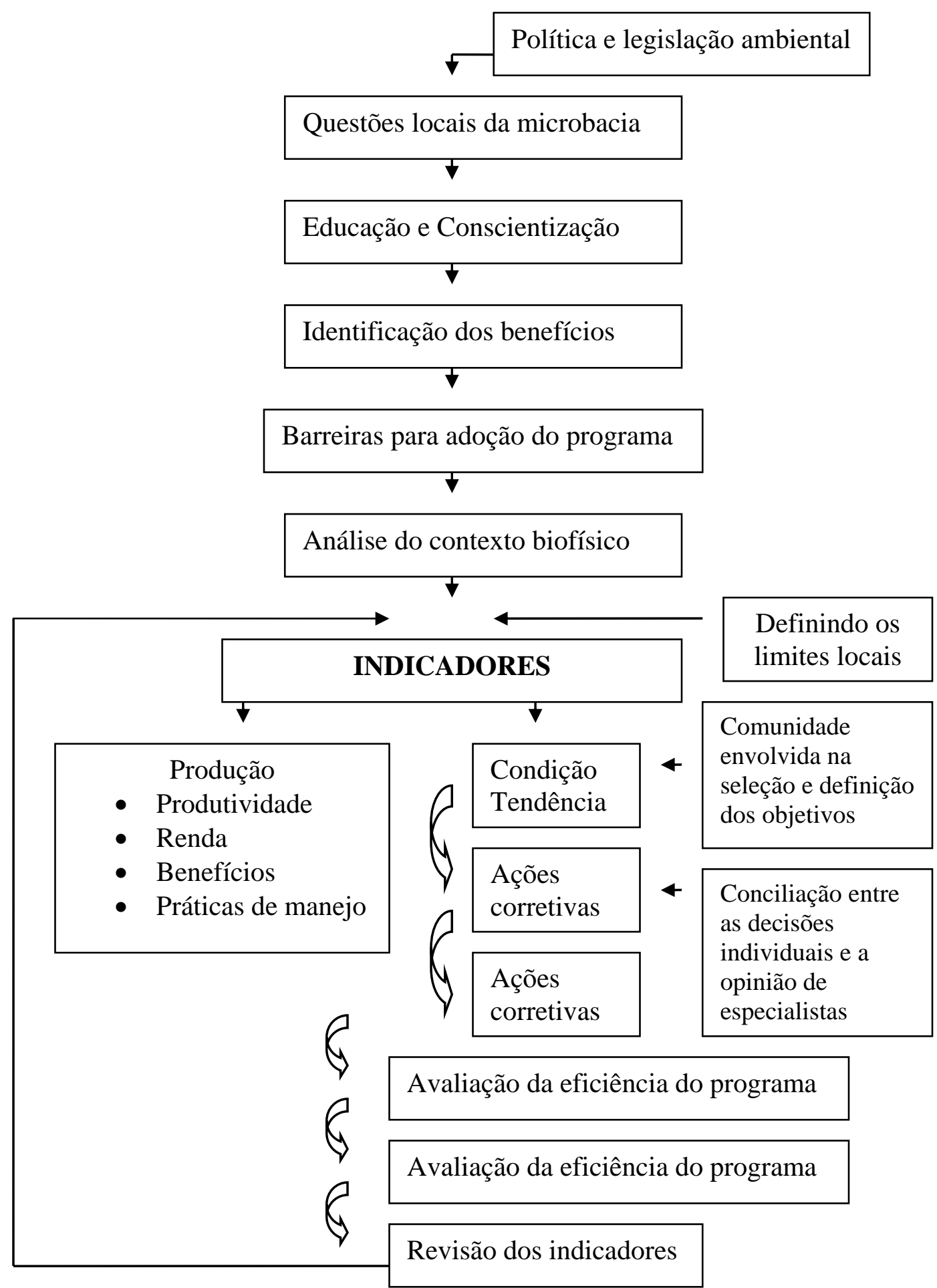

Figura 3 - Etapas necessárias para o sucesso de um programa de monitoramento (Walker et al.,1996) 


\subsection{Construção de cenários e participação pública em planejamento ambiental}

O planejamento ambiental em microbacias hidrográficas, com base em preceitos da agricultura sustentável e incorporando as ações do monitoramento, se fundamenta na interação e integração dos sistemas socioeconômicos e ecológicos que compõem o ambiente, trabalhando para que não apenas no presente, mas também no futuro, os recursos naturais estejam disponíveis para responderem às necessidades da sociedade.

O planejador interessado em trabalhar sob esta ótica deve considerar as relações entre os sistemas ecológicos, as necessidades socioculturais e os interesses econômicos da sociedade, mantendo uma visão holística e sistêmica, mesmo tendo que compartimentar o espaço, durante a análise, para depois integrá-lo. Deve estimular a participação da sociedade e trabalhar orientado pelo potencial e limites que o meio apresenta e não pela demanda estabelecida por uma gestão política administrativa equivocada (Santos, 2003). Este é um trabalho bastante complexo, nem sempre alcançado na prática.

Os cenários podem auxiliar os planejadores na análise da dinâmica dos elementos da microbacia e dos problemas ambientais decorrentes, sob o ponto de vista da sustentabilidade.

Wollenberg et al. (2000) destacam uma vantagem na utilização de cenários em planejamento que é o “encorajamento do pensamento crítico" sobre os riscos e relacionamentos do sistema, pois os cenários introduzem possibilidades hipotéticas e ajudam os participantes do planejamento a lidar com a incerteza, não a suprimindo, mas enfocando-a para entender a amplitude das implicações associadas.

Wilson (2000) sugere a importância dos cenários como ferramenta de manejo quando usada para aperfeiçoar a qualidade das tomadas de decisão e afirma que cenários não são um fim em si mesmos, somente são válidos quando seus resultados e implicações são incorporados aos planos de ação.

Assim como a escala espacial, já discutida anteriormente, a escala temporal em planejamento ambiental também é importante para a análise, situando o presente, o passado e o futuro da área estudada. 
A escala temporal pode ser representada por cenários, que devem ser construídos não somente a partir de diagnósticos da realidade técnica, mas também das propostas governamentais e dos conhecimentos e da cultura do homem do local (Santos, 2003).

O cenário pode ser estruturado, segundo esta mesma autora, a partir de uma perspectiva histórica, atual ou futura. Os cenários históricos, ao analisar a evolução de uma paisagem ao longo do tempo, permitem compreender o presente e indicar tendências de transformações futuras no meio. A construção de cenários atuais vai além de um simples diagnóstico do sistema e quando bem elaborados permitem identificar os conflitos entre as perspectivas técnicas, legais, institucionais e da sociedade. Os cenários futuros são medidas do tipo e do tempo de resposta possíveis a partir de propostas e ações humanas.

Ávila \& Santos (1989) esclarece que “cenários não são e não devem ser entendidos como prognósticos. Representam apenas uma forma de aumentar a compreensão das conseqüências de eventos potenciais e políticas de longo prazo”.

Os cenários são caracterizados por um conjunto de variáveis, as quais representam categorias de situações ou estados, podendo ser internas, isto é, estar sob o comando do planejador, ou externas, aquelas sobre as quais o planejador não tem controle. O estado de cada variável pode ser determinado por um ou mais indicadores e a posição em que o cenário futuro estará em relação ao presente dependerá do comportamento destes indicadores, que influem na conformação de cada variável ou a determinam (Ávila \& Santos,1989). É possível concluir então que os programas de monitoramento da microbacia estarão apoiando a construção dos cenários.

Na área ambiental vários são os exemplos do uso de cenários em tomadas de decisão. Johnson et al (1995) desenvolveram um estudo para determinar os efeitos da redução do potencial de deflúvio no médio Rio Snake, onde existe uma grande demanda de água para irrigação, sobre a vegetação ripária. Esta pesquisa foi dividida em vários subprojetos, incluindo: estudos florísticos e vegetacionais da mata ripária, modelagem hidrológica e a integração dos resultados da vegetação e da modelagem hidrológica com os mapeamentos feitos através de Sistema de Informações Geográficas. Os possíveis efeitos da redução do deflúvio sobre a extensão e distribuição espacial da zona ripária 
foram examinados através do uso de cenários que mostrou que a redução da zona ripária é comparável à redução do nível médio mínimo do rio.

Sparovek et al. (2002) ilustraram, através da metodologia dos cenários, a utilização de uma estrutura conceitual para definição da largura ótima de florestas ripárias. Czajkowski (2004) em sua pesquisa sugeriu como alternativas metodológicas ao Roteiro Metodológico para Planejamento de Unidades de Conservação de Uso Indireto adotado pelo IBAMA, dentre outras, o uso de cenários.

Wollenberg et al. (2000) utilizou o método de cenários no contexto das florestas tropicais com presença humana num enfoque participativo e adaptativo, confirmando que os cenários contribuem para a aquisição rápida de conhecimento, intercâmbio de idéias e entendimento compartilhado, além da tomada de consciência dos riscos.

Segundo Ávila \& Santos (1989) as vantagens que o uso da técnica de cenários traz são: a-) os planos resultantes do uso desta metodologia são mais flexíveis do que aqueles concebidos a partir de premissas rígidas, pois consideram o fato de que o futuro não pode ser exatamente conhecido: b-) estimula a absorção de pontos de vista diferentes e a criatividade; c-) incentiva o desenvolvimento de um sistema para monitorar tendências e eventos importantes; d-) ajuda a identificar o ponto no qual decisões importantes terão que ser tomadas no futuro.

Para Coates (2000) a principal vantagem do uso de cenários é que podem ser considerados como instrumento educacional, pois integram o que, de outro modo, estaria desconexo ou segmentado, e a integração é um grande passo para o entendimento.

Santos (2003) apresenta vários caminhos metodológicos para a construção de cenários, entre eles a modelagem, expressa em equações matemáticas; a simulação através de árvores de decisão, estruturando o problema e suas soluções; os Sistemas de Informações Geográficas, sobrepondo imagens ou mapas, etc. Esta autora cita o exemplo de construção de cenários a partir de informações sobre o território, sobre a legislação e sobre os interesses e expectativas dos atores sociais.

A metodologia dos cenários compartilha características importantes com as técnicas de Avaliações Participativas Rápidas, que incentivam o público envolvido a uma visão de futuro (Wollenberg et al., 2000). 
Atualmente há concordância de que a participação pública nos planejamentos ambientais deva ser ampla e representativa da sociedade. "Participar, em planejamento, significa tomar parte, integrar-se pela lógica ou pelo sentimento, fazer saber, saber comunicar, reconhecer diferentes interesses, expectativas e valores, identificar analogias, debater, negociar, evidenciar pontos comuns, definir interesses, aliançar, promover ajustes e tomar decisões de consenso sobre aquilo que é do uso ou do direito de todos, na presença de todos” (Santos, 2003).

Para Santos (2003) impor uma ordem pré-estabelecida, determinada por especialistas estranhos ao coletivo do local é, no mínimo, criar um planejamento desenraizado dos seus próprios propósitos, gerando um documento com resultados vazios.

Czajkowski (2004) destaca a importância da participação, em revisão de literatura sobre planejamento e gestão de unidades de conservação, considerando que há consenso de que a participação em tomadas de decisão pode contribuir para o manejo sustentável dos recursos naturais, podendo levar a processos de manejo mais robustos, aumentando a autoconfiança enquanto mantém a integridade dos recursos.

Esta mesma autora reconhece que estão sendo implementadas medidas que vão ao encontro de reivindicações de governos e populações locais por maior participação na formulação de políticas e decisões, pois os governos centrais, conscientes de sua limitada capacidade de cobrir investimentos financeiros e despesas, gradativamente estão delegando elementos de sua autoridade e responsabilidade aos escalões mais baixos do governo, para manejo regional e municipal de bacias hidrográficas, às universidades para investigação científica dos ecossistemas e de tecnologias para a sustentabilidade, ás ONGs e setor privado, para educação ambiental e recreação respectivamente.

Além da sobreposição de mapas e da descrição de restrições biofísicas, os cenários reais devem retratar as preocupações prioritárias e os cenários futuros devem refletir os anseios, tanto sob o ponto de vista técnico-científico como da comunidade local. Algumas dificuldades para este tipo de representação, entretanto, aparecem pelo fato de que conceitos ambientais internalizados pelos vários agentes envolvidos no 
planejamento se baseiam em referenciais distintos. Muitas vezes também a unidade do planejamento, como uma bacia hidrográfica, não é claramente entendida, resultando em uma abordagem segmentada, pontual e com base no senso comum (Santos, 2003).

Muitas outras dificuldades ocorrem quando se pretende inserir a participação efetiva da comunidade local em todo o processo do planejamento, pois não há tradição neste tipo de procedimento. Muitas vezes a participação é passiva ou manipulada, em outras as lideranças não estão interessadas ou um grupo dominante subjulga os outros participantes e impõem suas próprias opiniões, ou então o próprio planejador pode inibir a participação (Santos, 2003; Czajkowski, 2004).

Contudo, esta problemática é superada através de técnicas e do amadurecimento do processo participativo e pelas vantagens que o envolvimento da comunidade local representa no planejamento, isto é, a inclusão de seu conhecimento acumulado sobre as questões sociais, econômicas e ambientais da região e a consolidação de um compromisso comum na implementação das metas traçadas em conjunto, contribuindo assim para a busca do desenvolvimento sustentável.

\subsection{Os programas de microbacias hidrográficas e a determinação dos riscos ambientais para o planejamento socioeconômico e ambiental da microbacia}

Diante do desafio de propor um novo padrão de desenvolvimento rural tendo como suporte o planejamento integrado de microbacias hidrográficas, o governo federal instituiu em 05 de março de 1987, através do decreto nº 94.076 o Programa Nacional de Microbacias Hidrográficas. Assim também, vários Estados brasileiros, como o Rio Grande do Sul, o Paraná, Santa Catarina e São Paulo, em parceria com o Banco Mundial, desenvolvem seus programas estaduais de manejo de microbacias hidrográficas.

Estes programas incorporam como premissas básicas estabelecer um aumento de produção e produtividade na agricultura, elevando o nível sócio econômico do homem do campo, buscando promover ao mesmo tempo, a preservação e recuperação dos 
recursos naturais, com a participação ativa das comunidades rurais (Programa Estadual de Microbacias Hidrográficas - Manual Técnico, 1997).

O Banco Mundial vem apoiando programas de gestão dos recursos naturais com base em microbacias nos três Estados da região Sul desde o final da década de 80. O primeiro e mais arrojado foi desenvolvido no Paraná, onde 2.433 foram trabalhadas por extensionistas da rede pública, técnicos de ONGs, de prefeituras e de cooperativas. Em Santa Catarina o programa difundiu-se em 520 microbacias e no Rio Grande do Sul em 240 microbacias. (Programa das Nações Unidas para o Desenvolvimento-PNUD, 1999).

A avaliação destes programas mostra que nem sempre cada um de seus componentes atinge completamente a meta estabelecida, entretanto promovem mudanças comportamentais tanto nos produtores rurais, quanto nos técnicos executores e instituições participantes.

Por exemplo, a avaliação do Projeto Microbacias do Estado de Santa Catarina realizada pelo Instituto de Planejamento e Economia Agrícola (CEPA/SC) mostrou que o impacto deste projeto na recuperação da fertilidade, manejo e conservação do solo foi bastante positivo, onde apresentou seu maior sucesso e, muito embora a produtividade tenha aumentado e os custos de produção diminuído, a renda do produtor não melhorou devido a fatores alheios ao seu desempenho. No que diz respeito a adequação das estradas rurais, mereceu destaque a boa qualidade técnica das obras e a satisfação da comunidade das microbacias trabalhadas (76 \% do total), embora algumas metas físicas, como o acesso a propriedades não tenham sido cumpridas integralmente. Para acompanhar a qualidade da água o projeto montou um sistema de monitoramento hídrico em 14 microbacias piloto em todo o estado, que mostrou uma nítida tendência de melhoria da qualidade da água, principalmente no que se refere ao material em suspensão transportado, indicando que a estratégia de controle da erosão foi eficaz. As mudanças comportamentais podem não ter ocorrido no grau e intensidade desejados, entretanto este projeto deu início a um processo sem volta de mudança de comportamento dos técnicos, agricultores e instituições diretamente envolvidos (Instituto de Planejamento e Economia Agrícola de Santa Catarina, CEPA/SC, 1999). 
O Programa Estadual de Microbacias Hidrográficas de São Paulo (PEMBH) foi criado pela Secretária de Agricultura e Abastecimento através do decreto 27.329, de 03 de setembro de 1987.

Em 1997, a Coordenadoria de Assistência Técnica Integral (CATI), da Secretária de Agricultura e Abastecimento, redefiniu e reorganizou o Programa Estadual de Microbacias Hidrográficas juntamente com o Banco Mundial. O objetivo geral deste programa passou a ser "propiciar o aumento do bem-estar das populações rurais, através da implantação de sistemas de produção agropecuário que garantam a sustentabilidade socioeconômica e ambiental, com plena participação e envolvimento dos beneficiários e da sociedade civil organizada“. A implantação do programa é feita em microbacias com área média de 3.000 ha, com 60 produtores rurais e visa abranger 1.500 microbacias e 90.000 produtores rurais em todo o Estado de São Paulo (Programa Estadual de Microbacias Hidrográficas - Manual Técnico, 1997).

Estes programas estaduais de microbacias muitas vezes não provocam todos os impactos e resultados esperados, não atingem todas as metas estabelecidas, algumas inovações tecnológicas são rapidamente absorvidas outras nem tanto. Os trabalham nas microbacia muitas vezes não são balizados pelo conceito de microbacia como uma unidade hidrológica, o que é imprescindível, contudo estabelecem mudanças relevantes tanto físicas como comportamentais, dando início a processos de transformações importantes no campo.

Assim como os governos federal e estaduais, alguns municípios, como é o caso do Programa Piloto de Manejo de Bacias Hidrográficas - Consórcio de Alimentação dos Municípios do Alto Vale - COMAV (Marcondes, 1999), instituições públicas como a Embrapa e as universidades, além de organizações não governamentais e empresas privadas, também desenvolvem programas em microbacias hidrográficas com o objetivo de resguardar os recursos naturais.

Sob a ótica do programa, o impacto mais visível da agricultura paulista é a erosão hídrica, que ao degradar o solo causa dificuldades que levam à baixa produtividade e ao empobrecimento do meio rural. Assim, os problemas de produção agrícola ou de água para uso múltiplo têm suas causas interligadas, sendo as principais, 
aquelas vinculadas ao uso, manejo e conservação do solo e suas conseqüências no processo erosivo (Programa Estadual de Microbacias Hidrográficas - Manual Técnico, 1997).

Para a avaliação dos aspectos relacionados à adequação do uso do solo e aos riscos ambientais conseqüentes, muitos dos programas de microbacias utilizam o método de definição das classes de capacidade de uso das terras no diagnóstico e no planejamento socioeconômico e ambiental.

A classificação da capacidade de uso do solo visa estabelecer bases para o melhor aproveitamento das terras e devem ser utilizadas possibilitando que os fatores econômicos e sociais sejam considerados na elaboração de modificações no uso do solo. Os aspectos físicos que maior influência têm sobre o uso da terra, isto é, a natureza do solo, a declividade, a erosão, o uso atual, serão interpretados em conjunto para a determinação das classes de capacidade de uso (Bertoni \& Lombardi Neto, 1990).

A metodologia que utiliza a definição das classes de capacidade de uso para o planejamento da microbacia é bastante difundida, sendo recomendada inclusive na lei estadual sobre o uso do solo e no Programa Estadual de Microbacias Hidrográficas do Estado de São Paulo.

Segundo o Artigo $4^{\circ}$ do Decreto Estadual No 41.719, de 16 de abril de 1997, que regulamenta a Lei $\mathrm{n}^{0}$ 6.171, de 04 de julho de 1988, alterada pela Lei $\mathrm{n}^{0}$ 8.421, de 23 de novembro de 1993 que dispõe sobre o uso, conservação e preservação do solo agrícola, a utilização e manejo do solo agrícola serão executados mediante planejamento embasado na capacidade de uso das terras, de acordo com as técnicas de conservação do solo agrícola correspondentes. No Parágrafo $1^{\circ}$ esclarece que os trabalhos de determinação das classes de capacidade de uso dos solos e de definição de tecnologia serão priorizados pela Secretaria de Agricultura e Abastecimento quando houver licitação formal do interessado ou quando for constatada, em inspeção, irregularidade no uso do solo agrícola.

No seu Parágrafo único do Artigo $3^{\circ}$, fica claro que a unidade de planejamento e ação a que se refere tal decreto pode ser a propriedade rural, a microbacia ou a região. 
O Programa Estadual de Microbacias Hidrográficas (PEMBH) de São Paulo utiliza as classes de capacidade de uso do solo na elaboração dos Projetos Individuais de Propriedades das microbacias (Programa Estadual de Microbacias Hidrográficas Manual Técnico, 1997).

Este tema é bastante desenvolvido em planejamento, porque fornece respostas básicas sobre o uso adequado, com práticas adequadas, ou a ocorrência de conflitos envolvendo o uso atual e o uso recomendável. Esta análise norteia muitas tomadas de decisão, tanto do ponto de vista da conservação ambiental, da vocação agropecuária, do risco de erosão, da produtividade, de controle de impactos ou da identificação de tecnologias adequadas (Santos, 2003).

De maneira geral, as terras podem ser definidas, segundo Bertoni \& Lombardi Neto (1990), nas seguintes categorias, nas quais as classes de capacidade de uso também se baseiam: a-) cultiváveis, b-) cultiváveis apenas em casos especiais de algumas culturas permanentes e adaptadas em geral para pastagens ou florestas, e c-) terras que não se prestam para vegetação produtiva.

Estes mesmos autores apresentam os critérios adotados para se proceder a classificação da capacidade de uso: os da estabilidade e produtividade do solo, o das obstruções contra o livre emprego de máquinas e o do ambiente ecológico.

As classes de capacidade de uso não fornecem todos os elementos necessários ao planejamento ambiental da microbacia. Embora considere alguns aspectos ecológicos, está fundamentada essencialmente sob uma visão econômica da produção agrícola.

Lepsch et al. (1991), no Manual para Levantamento Utilitário do Meio Físico e Classificação de Terras no Sistema de Capacidade de Uso, afirmam que usar a terra de acordo com sua capacidade de sustentação e produtividade econômica, colocando os recursos naturais à disposição do homem para seu melhor uso e benefício e preservandoo para gerações futuras, é o primeiro passo em direção à agricultura correta.

Entretanto estes mesmos autores consideram que "o sistema de classificação de terras em capacidade de uso foi elaborado primordialmente para atender a planejamentos de práticas de conservação do solo. Contudo, leva em conta outros fatores, além daqueles de exclusivo interesse às práticas de controle à erosão, tais como impedimentos 
à mecanização, produtividade dos solos, risco de inundação.... Admite-se, todavia, que mesmo nesses casos, outro sistema possa servir melhor aos propósitos visados, visto que as classificações técnicas, logicamente, atendem melhor a suas finalidades quando os objetivos para os quais foram elaboradas são os mais específicos possíveis.”

Outra metodologia bastante utilizada em manejo de microbacias para analisar o risco de degradação do solo é a avaliação do potencial natural de erosão e risco de erosão.

Ela estima o risco potencial de erosão de um solo, considerando não apenas suas propriedades intrínsecas, mas também as condições climáticas e topográficas às quais o solo está sujeito. Esta análise não considera a cobertura vegetal ou as práticas conservacionistas. É uma simplificação da "Equação Universal de Perdas de Solo (EUPS), onde os fatores considerados são: erosividade da chuva (R), erodibilidade do solo (K), fator comprimento de rampa (L) e fator grau de declive (S) (Brandão, 2001).

Esta avaliação expressa a susceptibilidade de determinada área à erosão, sem levar em consideração os fatores antrópicos. É bastante adequada ao planejamento ambiental, entretanto pode ser complementada com outras avaliações.

\subsection{O Paradigma Contemporâneo da Ecologia}

O manejo de ecossistema naturais ou antrópicos é feito com base em experiências historicamente acumuladas e em práticas oriundas de conceitos científicos, assim, partindo-se de diferentes abordagens científicas, diferentes resultados e objetivos podem ser alcançados.

Um paradigma é o modo de uma ciência ver o mundo. Envolve observações que levam a suposições empíricas, ditando os questionamentos e as abordagens científicas. Os paradigmas da ecologia têm sofrido grandes transformações que conseqüentemente implicam também em mudanças nas estratégias de manejo dos recursos naturais (Pickett \& Ostfeld, 1995).

É fundamental, portanto, esclarecer em que bases da teoria ecológica este trabalho foi desenvolvido e estabelecer as relações entre o novo paradigma da ecologia e 
o manejo ecossistêmico ou manejo adaptativo em microbacias hidrográficas (mesoescala) de uso agrícola.

Neste aspecto, é também interessante estabelecer algumas análises considerando os agroecossistema (microescala), já que este se baseia em princípios ecológicos e na compreensão dos ecossistemas naturais (Gliessman, 2001).

O paradigma clássico da ecologia considera a idéia do Balanço da Natureza, sugerindo que sistemas naturais são fechados e auto-reguláveis (Pickett \& Ostfeld, 1995).

A microbacia hidrográfica, componente da mesoescala, é um sistema natural aberto, que interage com agentes externos aos seus limites geográficos. Então, um estudo nesta área seria deficiente se conduzido por essas suposições. Existe na microbacia um fluxo interno e externo de energia, nutrientes, poluentes, organismos e materiais diversos, além de uma interação dos ciclos naturais. Por isso, não se poderia preservar a água e os recursos naturais de uma microbacia apenas isolando-a, pois o ciclo hidrológico, os processos físicos e químicos do solo, a dinâmica da flora e fauna sofrem influências de agentes controladores que muitas vezes estão além dos divisores de águas.

Da mesma forma ocorre com os agroecossistemas que fazem parte da microbacia e são também sistemas abertos, onde parte da energia recebida de diversas formas, inclusive pelo uso de insumos químicos, é levada para fora do sistema através das colheitas (Altieri, 2002; Gliessman, 2001).

O paradigma clássico enfatiza também o ponto de equilíbrio estável dos sistemas ecológicos e acredita na sucessão como processo determinístico (Pickett \& Ostfeld, 1995). Estudos, entretanto, demonstram que não há um único estado clímax, um estado estável para os sistemas naturais, por exemplo, para as formações vegetais, nem tampouco uma rota fixa para alcançá-lo em caso de ocorrer alguma mudança. Existe um mosaico de situações e estados naturais persistentes estabelecidos por acontecimentos históricos no interior ou entorno deles e os caminhos e fases da sucessão ecológica são específicos e individuais. 
Ainda contrariando premissas do paradigma clássico, a visão do novo paradigma da ecologia é de que as perturbações naturais não são eventos excepcionais e de que o homem não deve ser excluído enquanto fator ecológico normal (Pickett \& Ostfeld, 1995), o que também é confirmado pelos estudos dos processos naturais na microbacia hidrográfica.

Os distúrbios naturais são inerentes ao sistema e a ordem em que ocorrem determinam o estado, a composição, a estrutura dos recursos naturais da microbacia. A ação humana na microbacia hidrográfica e nos agroecossistemas é de grande importância, está inserida no sistema, e é representada, sobretudo, neste caso, através da prática da agricultura, portanto não pode ser excluída dele. A inserção da agricultura neste contexto reforça todos os aspectos já discutidos e refutados do paradigma clássico da ecologia. O uso dos recursos naturais para a produção de bens demandados pela sociedade potencializa os distúrbios e os fluxos de organismos (pragas e doenças, por exemplo) e compostos químicos (adubação, calagem, defensivos químicos, etc ).

É relevante também salientar que num Plano de Manejo Integrado de Microbacias Hidrográficas as perturbações naturais, tanto de origem interna como externa à microbacia, como cheias, secas, incêndios etc, devem ser previstas. Por exemplo, enchentes que podem prejudicar a passagem em estradas que, inadequadamente, atravessam cursos d' água ou a zona ripária; as ações para a preservação e a recuperação de áreas com vegetação natural precisam considerar a possibilidade de invasão de fogo, tradicionalmente usado em lavouras canavieiras. Além disso, é importante na recuperação da mata ciliar ser considerado o processo de sucessão, isto é, manejar e conservar os processos e a dinâmica da floresta.

As limitações do paradigma clássico clamam por um novo paradigma da ecologia, que é representado pela idéia de "Fluxo da Natureza". O termo fluxo destaca a variação, a fluidez e as transformações nos sistemas naturais.O novo paradigma da ecologia reconhece que os sistemas são abertos, regulados por eventos que podem ser originários no exterior dos seus limites, neles os pontos de equilíbrio estável são raros, são afetados por distúrbios naturais e incorporam as ações humanas e seus efeitos (Pickett \& Ostfeld, 1995). 
Desta forma, a elaboração de um Plano de Manejo Integrado de Microbacias Hidrográficas, que inclua o monitoramento ambiental, não pode ignorar o paradigma contemporâneo da ecologia para que seu direcionamento científico e suas estratégias de manejo não negligenciem a dinâmica, as conexões, os fluxos, as estruturas dos sistemas ambientais.

A idéia de fluxo natural tem sido sedimentada através do conceito de manejo adaptativo. Sob esta estratégia, as metas dos planos de manejo são articuladas através do uso de um modelo do sistema que deve incorporar os componentes, as interações, e as prováveis flutuações. Então, técnicas apropriadas são aplicadas ao sistema, os resultados monitorados, e as táticas, ou até mesmo as metas, são modificadas de acordo com as respostas do sistema. Em outras palavras, o manejo pode, como a ciência, ser usado para testar hipóteses. A diferença é que no teste das hipóteses do manejo, as propostas podem ser mudadas se forem consideradas irreais, ineficazes ou se opuserem à sobrevivência do sistema (Pickett \& Ostfeld, 1995).

Na busca da preservação do ecossistema, da proteção do solo, da moderação climática, da biodiversidade, da ciclagem de nutrientes, da qualidade da água e dos valores culturais e sociais, deve-se voltar a atenção para a introdução de um plano de manejo sustentável na microbacia hidrográfica que privilegie os processos naturais e o contexto social, ecológico, econômico, cultural no qual está inserida, compatível com o uso da terra pelo homem. A sustentabilidade pode ser definida como um alvo móvel, implicando em sua eterna busca, cujo rumo será mantido, ao longo do tempo, pelas informações obtidas pelo monitoramento dos indicadores de sustentabilidade (Lima, 1999).

O paradigma clássico da ecologia simplifica o mundo natural e a idéia do Balanço da Natureza é uma metáfora cultural, mal articulada, ao invés de um conceito científico (Pickett \& Ostfeld, 1995). Em consonância com o paradigma contemporâneo, mais do que a manutenção da integridade biofísica da microbacia é importante, num plano de manejo, prever a possibilidade de mudanças em seu estado original, desde que seja garantida a sua sustentabilidade (Lima, 1999). 
As mudanças de paradigmas sugerem mudanças também nos objetivos, nas práticas e nos métodos previstos em um plano de manejo para determinado sistema, além de ressaltarem também a importância da escala para a análise, como no caso, a microbacia hidrográfica, representando a mesoescala e os agroecossistemas nela inseridos, representando a microescala.

A essência do presente trabalho tem seus fundamentos nos novos paradigmas da ecologia e a idéia de fluxo da natureza apóia o esforço para a busca de um manejo sustentável. 


\section{MATERIAL E MÉTODOS}

\subsection{A área de estudo}

\subsubsection{Localização}

Este trabalho foi realizado na Microbacia Hidrográfica do Ribeirão São João, que possui área de 3.656 ha e está localizada no centro do Estado de São Paulo, no município de Mineiros do Tietê (Figura 4), entre os paralelos $22^{\circ} 22^{\prime}$ e $22^{\circ} 27^{\prime}$ Sul e os meridianos $48^{\circ} 22^{\prime}$ e $48^{\circ} 30^{\prime}$ Oeste. Integra a Bacia Hidrográfica do Rio Tietê e é formada

pelo Ribeirão São João e pelo Córrego do Borralho, estando inserida no perímetro da Área de Proteção Ambiental Corumbataí (APA Corumbataí). Faz parte da Unidade de Gerenciamento de Recursos Hídricos (UGRHI) Tietê - Jacaré.

Esta é uma das microbacias selecionadas pela CATI para compor o Programa Estadual de Microbacias Hidrográficas e onde está sendo desenvolvido o processo de monitoramento sócio-ambiental do referido programa. 


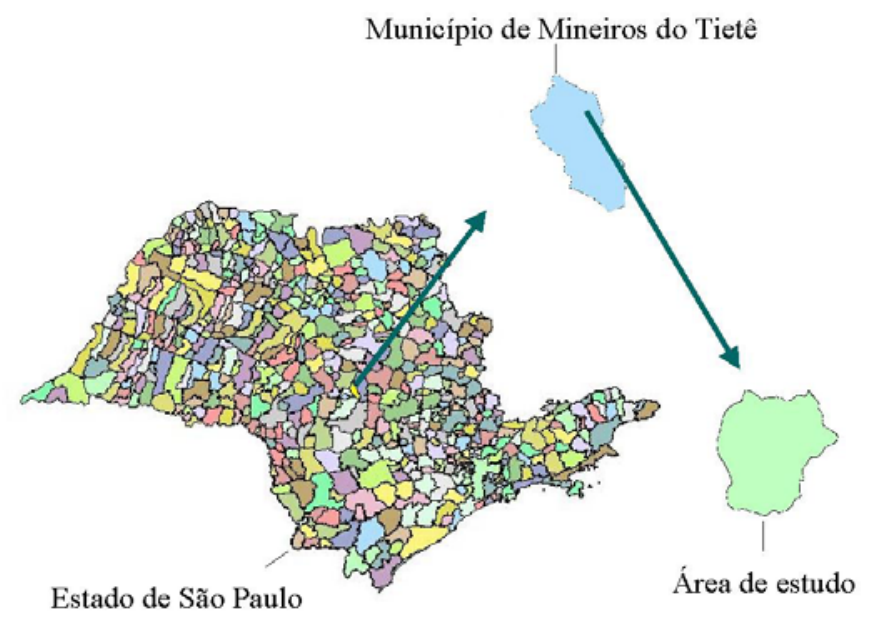

Figura 4 - Mapa do Estado de São Paulo mostrando a localização do município de Mineiros do Tietê e apontando o local aproximado da área de estudo

\subsubsection{Clima}

Segundo Setzer (1966), pela Classificação do Clima do Sistema Internacional de Koeppen, a Microbacia do Ribeirão São João apresenta tipo climático Cwa, isto é, quente com invernos secos. O total de chuvas do mês mais seco é menor que $30 \mathrm{~mm}$, a temperatura do mês mais quente está acima de $22^{\circ} \mathrm{C}$ e a do mês mais frio está abaixo de $18^{\circ} \mathrm{C}$.

A Figura 5 apresenta os dados pluviométricos registrados, nos últimos 30 anos (1974 a 2004), na Estação Experimental do Instituto Agronômico de Campinas (22 $17^{\prime} \mathrm{S}$ e $48^{\circ} 34^{\prime} \mathrm{W}$ ) localizada no município de Jaú a aproximadamente $30 \mathrm{~km}$ de distância da Microbacia do Ribeirão São João. Embora não sejam dados específicos da área de estudo, permitem a caracterização regional dos índices pluviométricos. A média da precipitação total anual, no período de 1974 a 2003 é de 1.474 mm, a maior precipitação observada neste período foi de $2.060 \mathrm{~mm}$ em 1983 e a menor $1.036 \mathrm{~mm}$ em 1984 . No entanto, dados disponíveis do período de 1942 a 2003 (62 anos) permitem observar que ocorreram anos mais secos como o ano de 1944 quando a precipitação anual atingiu apenas $718 \mathrm{~mm}$. 


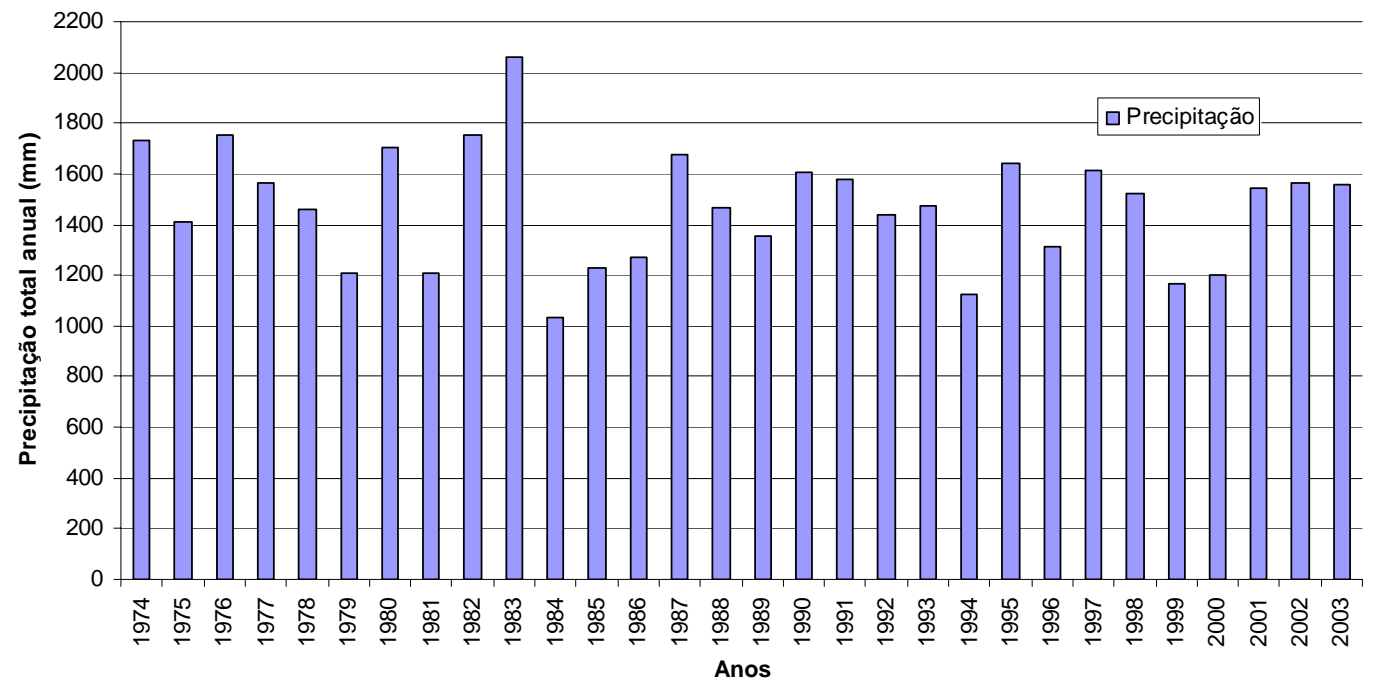

Figura 5 - Gráfico da distribuição da precipitação total anual $(\mathrm{mm})$ na Estação Experimental do Instituto Agronômico de Campinas (22 $2^{\circ} 7^{\prime} \mathrm{S}$ e $48^{\circ} 34^{\prime} \mathrm{W}$ ) localizada no município de Jaú, entre 1974 e 2003

O clima na região de Jaú apresenta um caráter estacional com um período quente e chuvoso, correspondente aos meses de novembro a março em que as precipitações médias são superiores à $150 \mathrm{~mm}$ mensais, podendo atingir mais do que $250 \mathrm{~mm}$, e um período mais frio e seco, de junho a agosto, em que as precipitações médias são iguais ou inferiores à $50 \mathrm{~mm}$ (Figura 6). 


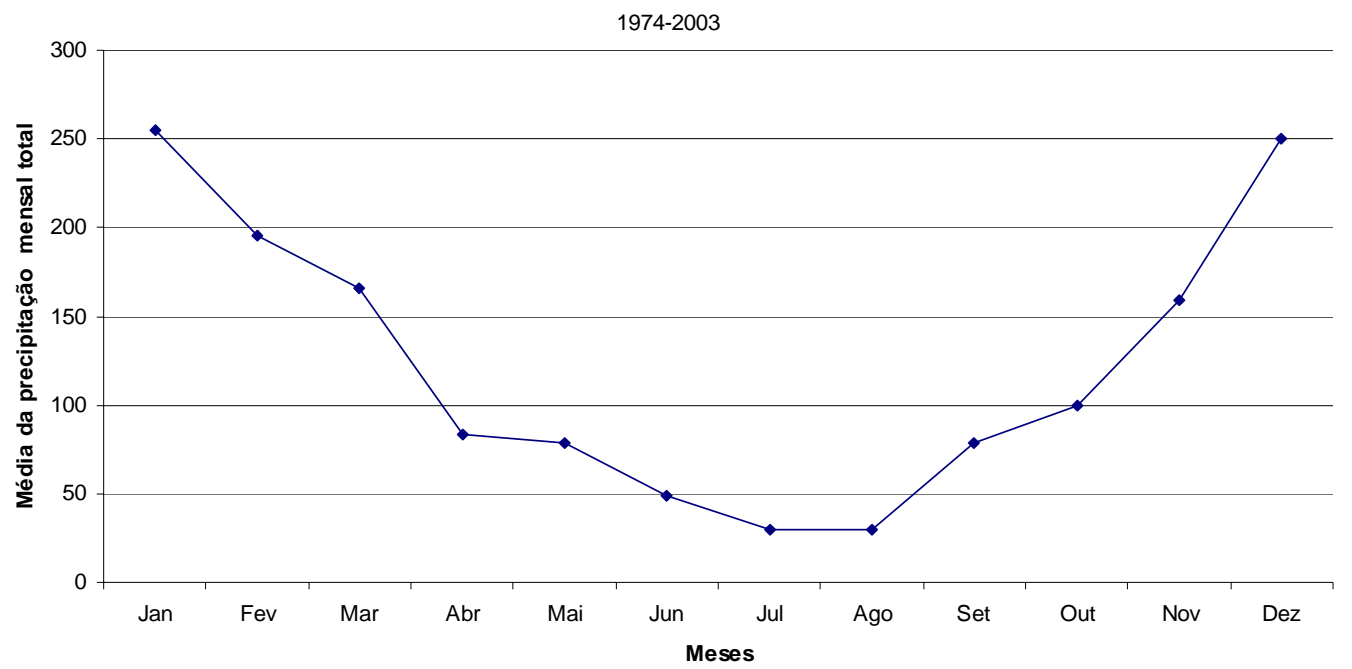

Figura 6 - Gráfico da distribuição das médias de precipitação mensal total $(\mathrm{mm})$ na Estação Experimental do Instituto Agronômico de Campinas (22 ${ }^{\circ} 17^{\prime} \mathrm{S}$ e $48^{\circ} 34^{\prime} \mathrm{W}$ ) localizada no município de Jaú, entre 1.974 e 2.003

\subsubsection{Caracterização socioeconômica, percepção da qualidade ambiental e manejo agrícola}

O levantamento socioeconômico e ambiental da microbacia do Ribeirão São João, realizado pela Casa da Agricultura de Mineiros do Tietê em 2002, cadastrou 153 unidades de produção agropecuária (UPA). Cada UPA corresponde à gleba explorada sob responsabilidade de um produtor rural (proprietário e arrendatário).

Assim, em vários casos, para cada propriedade rural, foram respondidos dois ou mais questionários, por se tratar de imóvel explorado pelo proprietário e por um ou mais arrendatários. Nesta microbacia foram identificadas 111 propriedades rurais, das quais $82,9 \%$ possuem áreas menores de 50 hectares (Quadro 1) e registrados 99 produtores (Quadro 2), sendo que 14 proprietários não exploram área alguma, isto é, suas propriedades estão totalmente arrendadas. Dessa forma, só foram respondidas as questões sobre manejo e percepção ambiental de 139 questionários (153 UPAs, excluindo 14 que não são exploradas pelos proprietários). 


\begin{tabular}{|c|c|c|c|c|}
\hline \multirow{2}{*}{ Estratificação } & \multicolumn{4}{|c|}{ PROPRIEDADES } \\
\cline { 2 - 5 } & $\mathbf{N .}^{\mathbf{0}}$ & $\mathbf{\%}$ & ha & \% \\
\hline ATÉ $\mathbf{1 0}$ ha & 28 & 25,2 & 182,8 & 5,0 \\
\hline $\mathbf{1 0} \rightarrow \mathbf{5 0}$ & 64 & 57,7 & $1.648,9$ & 45,1 \\
\hline $\mathbf{5 0} \rightarrow \mathbf{1 0 0}$ & 15 & 13,5 & 1001,7 & 27,4 \\
\hline $\mathbf{1 0 0} \rightarrow \mathbf{2 0 0}$ & 3 & 2,7 & 468,0 & 12,8 \\
\hline $\mathbf{2 0 0} \rightarrow \mathbf{5 0 0}$ & 1 & 0,9 & 354,6 & 9,7 \\
\hline TOTAL & 111 & 100,0 & 3656,0 & 100,00 \\
\hline
\end{tabular}

Fonte: Casa da Agricultura de Mineiros do Tietê (CATI/SAA-SP).

Quadro 1 - Estrutura fundiária da microbacia do Ribeirão São João

\begin{tabular}{|c|c|c|c|c|c|c|}
\hline \multirow{3}{*}{$\begin{array}{c}\text { Área } \\
\text { explorada } \\
\text { pelos } \\
\text { produtores } \\
\text { rurais }\end{array}$} & \multirow{3}{*}{$\begin{array}{c}\mathrm{N}^{\mathbf{0}} \text { de } \\
\text { produtores } \\
\text { rurais }\end{array}$} & \multirow{3}{*}{$\begin{array}{c}\text { \% sobre } \\
\text { o total }\end{array}$} & \multicolumn{4}{|c|}{ Condição de Uso da Terra } \\
\hline & & & \multicolumn{2}{|c|}{ Proprietários } & \multicolumn{2}{|c|}{ Arrendatário } \\
\hline & & & $\mathbf{N}^{\mathbf{o}}$ & $\begin{array}{l}\text { \% do } \\
\text { Total }\end{array}$ & $\mathbf{N}^{\mathbf{0}}$ & $\begin{array}{l}\text { \% do } \\
\text { Total }\end{array}$ \\
\hline$<50$ ha & 68 & 68,7 & 63 & 63,6 & 5 & 5,1 \\
\hline 50 - 200 ha & 18 & 18,2 & 16 & 16,2 & 2 & 2,0 \\
\hline$>200$ & 13 & 13,1 & 09 & 9,1 & 4 & 4,1 \\
\hline TOTAL & 99 & 100,0 & 88 & 88,9 & 11 & 11,2 \\
\hline
\end{tabular}

Fonte: Casa da Agricultura de Mineiros do Tietê (CATI/SAA-SP)

Quadro 2 - Caracterização dos produtores rurais da microbacia do Ribeirão São João quanto à área explorada e condição de uso da terra 
A classificação dos produtores rurais mostra que $68,7 \%$ dos produtores rurais da microbacia exploram área menor que 50 hectares (Quadro 2).

O levantamento sócio-econômico e ambiental fornece dados, obtidos como os produtores rurais, que permitem a identificação de problemas sociais, econômicos e dos sistemas de manejo empregados na produção agropecuária, além de possibilitar uma avaliação de como os produtores percebem as questões ambientais da microbacia.

Algumas informações mais importantes para o presente estudo estão a seguir.

No que diz respeito ao uso da água (Quadro 3), 49 produtores não usam a água do rio que passa pelas propriedades da microbacia. Vários agricultores e a Usina da Barra S/A Açúcar e Álcool, assim como outras propriedades sob sua direção, que exploram a cana de açúcar, possuem lugares apropriados para encher com água os tanques para diluição e aplicação dos agrotóxicos (herbicidas, principalmente). Entretanto, $52 \%$ utilizam, mesmo que raramente, as águas dos rios para abastecimento de equipamentos de pulverização. A água é utilizada para abastecimento humano (55 produtores), abastecimento de instalações animais (29 produtores), irrigação de culturas (32 produtores), por animais diretamente (39 produtores), para escoamento de resíduos orgânicos, residenciais ou animais ( 8 produtores) e energia elétrica ou hidráulica (8 produtores).

As questões sobre qualidade e quantidade de água foram respondidas por aqueles que a utilizam e por aqueles que possuem cursos d' água em suas propriedades ou nas proximidades (79 produtores ou 56,8 \%). A percepção desses produtores rurais indica que a qualidade da água não permite o seu uso (54\% dos produtores) e que ela é suficiente durante o ano todo $(85 \%)$.

Para as questões de solo e estradas rurais (Quadro 4), 94 \% dos produtores da microbacia concordam que há ocorrência de erosão em sua UPAs. Entre as práticas agrícolas indicadas, 35 produtores responderam que não há proteção conservacionista em suas UPAs, 79 responderam que usam práticas mecânicas, 4 responderam que usam práticas vegetativas e 53 produtores possuem mata ciliar em suas UPAs. 
Quanto a trafegabilidade das estradas que servem à propriedade, $4 \%$ dos produtores entrevistados consideram que as estradas apresentam problemas o ano todo, $60 \%$ deles julgam que não são trafegáveis na época das chuvas e $36 \%$ que são trafegáveis durante o ano todo.

As enchentes nos cursos d' água ocorrem todos os anos nas épocas de chuva, segundo $63 \%$ dos produtores rurais da microbacia.

\begin{tabular}{|c|c|c|}
\hline Uso da água do curso d’água & $\begin{array}{l}\mathrm{N}^{\mathrm{o}} \text { de } \\
\text { respostas }\end{array}$ & $\%$ \\
\hline \multicolumn{3}{|l|}{ 1- como utiliza a água do curso d' água * } \\
\hline a- Não utiliza a água do curso d' água & 60 & - \\
\hline b- Abastecimento humano & 55 & - \\
\hline c- Abastecimento de instalações animais & 29 & - \\
\hline d- Irrigação de culturas & 32 & - \\
\hline e- Por animais diretamente & 39 & - \\
\hline f- Para escoamento de resíduos orgânicos & 8 & - \\
\hline g- Energia (elétrica ou hidráulica) & 8 & - \\
\hline \multicolumn{3}{|l|}{$\begin{array}{l}\text { 2- quanto a sua qualidade, a água pode ser utilizada, } \\
\text { sem qualquer problema com que freqüência }\end{array}$} \\
\hline a- sempre pode ser utilizada & 17 & 22 \\
\hline b- raramente não pode ser utilizada & 19 & 24 \\
\hline c- nunca pode ser utilizada & 43 & 54 \\
\hline Total & 79 & 100 \\
\hline \multicolumn{3}{|l|}{$\begin{array}{l}\text { 3- com relação à quantidade, a água utilizada pode ser } \\
\text { classificada }\end{array}$} \\
\hline a- suficiente durante todo o ano & 67 & 85 \\
\hline b- insuficiente nos períodos de seca & 12 & 15 \\
\hline Total & 79 & 100 \\
\hline
\end{tabular}

* ao responder, o produtor rural poderia escolher mais de uma alternativa.

Fonte: Casa da Agricultura de Mineiros do Tietê (CATI/SAA-SP)

Quadro 3 - O uso da água pelos produtores rurais da microbacia do Ribeirão São João 


\begin{tabular}{|c|c|c|}
\hline Solos e estradas & $\begin{array}{l}\mathrm{N}^{\mathbf{0}} \text { de } \\
\text { respostas }\end{array}$ & $\%$ \\
\hline \multicolumn{3}{|l|}{ 1-quanto à ocorrência de erosão } \\
\hline a- há ocorrência de erosão & 131 & 94 \\
\hline b- não há ocorrência de erosão & 8 & 6 \\
\hline Total & 139 & \\
\hline \multicolumn{3}{|l|}{$\begin{array}{l}\text { 2- indique quais práticas conservacionistas estão presentes na } \\
\text { UPA* }\end{array}$} \\
\hline a- não há proteção conservacionista & 35 & - \\
\hline b- práticas mecânicas & 79 & - \\
\hline c- práticas vegetativas & 4 & - \\
\hline d- mata ciliar natural & 53 & - \\
\hline \multicolumn{3}{|l|}{$\begin{array}{l}\text { 3- Quanto a trafegabilidade das estradas que servem à } \\
\text { propriedade }\end{array}$} \\
\hline a- apresentam problemas o ano todo & 5 & 4 \\
\hline b- não são trafegáveis na época das chuvas & 84 & 60 \\
\hline c- são trafegáveis durante o ano todo & 50 & 36 \\
\hline Total & 139 & \\
\hline \multicolumn{3}{|l|}{$\begin{array}{l}\text { 4- Quanto às enchentes do curso d' água na propriedade, estas } \\
\text { ocorrem com que freqüência: }\end{array}$} \\
\hline a- todos os anos nas épocas das águas & 88 & 63 \\
\hline b- somente em anos de chuvas muito fortes & 26 & 19 \\
\hline c- não ocorrem enchentes & 25 & 18 \\
\hline Total & 139 & \\
\hline
\end{tabular}

* ao responder, o produtor rural poderia escolher mais de uma alternativa.

Fonte: Casa da Agricultura de Mineiros do Tietê (CATI/SAA-SP)

Quadro 4 - Conservação do solo e estradas da microbacia do Ribeirão São João 
Manejo: Os produtores, tanto os pequenos, quanto os médios e grandes, segundo os levantamentos da Casa da Agricultura do município, empregam na cultura de cana de açúcar, a principal atividade agrícola da região, o plantio convencional, isto é, aquele com maior mobilização do solo (operações de aração e gradagem, com inversão da leiva e nivelamento), utilizam-se de análises de solo e calagem, como tecnologias básicas recomendadas, além de adotarem como prática conservacionista, o terraceamento. Nesta cultura, também ocorre o emprego intensivo de herbicidas, que se encontram entre as faixas de toxidez II-amarela (altamente tóxica) e III-azul (medianamente tóxica). A colheita da cana de açúcar é feita entre abril e dezembro.

Em pastagens não é comum, a não ser em alguns poucos casos, o uso de análise de solo, de calagem e de agrotóxicos, nem a adoção de práticas conservacionistas mecânicas, como é o terraceamento, $\mathrm{O}$ mesmo acontece com a silvicultura.

Em culturas anuais (milho, arroz, feijão), cultivadas, de maneira geral, para o consumo próprio ou para as pequenas vendas locais, os produtores empregam o plantio convencional, sendo a análise de solo, a calagem e o uso de agrotóxicos práticas esporádicas, e a conservação do solo através do terraceamento, sem manutenção adequada. O controle das ervas invasoras é feito através de capinas manuais, principalmente. Na cafeicultura, também pouco representativa na microbacia, a análise de solo, a calagem, os agrotóxicos, o terraceamento são utilizados, mas muitas vezes sem um planejamento técnico adequado. Alguns agricultores plantam culturas anuais nas entre-linhas do café e o controle das ervas invasoras é feito através de capinas manuais, roçadeiras, gradagens ou aplicação de herbicidas. Nas culturas anuais e perenes os produtores não realizam o manejo integrado de pragas.

$\mathrm{Na}$ área urbana, que fica dentro dos limites da microbacia, ocorre um sério problema de falta de infra-estrutura adequada, principalmente no que diz respeito a captação das águas pluviais. Isso ocasiona processos erosivos nas áreas agrícolas marginais à cidade, devido ao grande escoamento superficial originário das áreas impermeáveis dos bairros periféricos. 


\subsubsection{Critério de escolha}

Coube ao Conselho de Desenvolvimento Rural da Regional de Jaú selecionar os municípios que apresentaram proposta de adesão ao Programa Estadual de Microbacias Hidrográficas, considerando, segundo o Manual do Programa, os seguintes parâmetros: explorações predominantes representadas por culturas anuais e de alimentos básicos, receptividade por parte do município, concentração de pequenos produtores rurais, ausência de trabalhos similar de microbacia, presença de Unidades de Conservação de Uso Indireto e áreas de entorno e áreas com maior uso de agrotóxicos.

No município, a priorização da microbacia a ser trabalhada pelo Programa Estadual de Microbacias Hidrográficas foi de responsabilidade do Conselho Municipal de Desenvolvimento Rural de Mineiros do Tietê, formado pelos representantes dos produtores rurais, que adotou, também, segundo o Manual do Programa, os seguintes parâmetros: nível de degradação ambiental, concentração de pequenos produtores, explorações predominantes representadas por culturas anuais e de alimentos básicos, presença de mananciais de abastecimento humano, receptividade por parte dos produtores, área da microbacia dentro ou próxima de Unidade de Conservação de Uso Indireto e maior porcentagem de Área de Preservação Permanente na microbacia.

A nível Estadual, a Microbacia Hidrográfica do Ribeirão São João está localizada na área de Prioridade 2, estabelecida pela sobreposição dos mapas de degradação erosiva dos solos do Estado de São Paulo e mapa de indigência (Programa Estadual de Microbacias Hidrográficas - Manual Técnico, 1997).

\subsection{Metodologia}

\subsubsection{Base de dados descritivos dos aspectos agrícolas, ecológicos e socioeconômicos da microbacia do Ribeirão São João, necessários à composição dos cenários}




\section{Base cartográfica}

A base cartográfica para caracterização agrícola e ambiental da microbacia do Ribeirão São João, para a construção dos cenários e determinação dos riscos ambientais, foi preparada com dados básicos extraídos das folhas topográficas, em escala 1 : 10.000, do Plano Cartográfico do Estado de São Paulo, Secretaria de Estado dos Negócios do Interior, Coordenadoria de Ação Regional - Instituto Geográfico e Cartográfico de 1980, enriquecidos com informações obtidas das fotografias aéreas, escala $1: 30.000$ do ano de 2000 e levantamentos de campo. O registro das informações foi realizado com o "software” ILWIS, usando a mesa digitalizadora.

Todos os arquivos de imagem foram construídos com pixels de $30 \mathrm{~m}$ x 30m, nas

direções $\mathrm{X}$ e Y. O tamanho do pixel pode, em alguns casos, comprometer o nível de detalhe da informação original, entretanto facilita a obtenção de arquivos de tamanho compatível para o sistema computacional.

- Carta base (escala 1:10.000): contém a rede hidrográfica, a malha viária e as isolinhas altimétricas (eqüidistantes verticalmente 5 metros), com visualização no SIG ENRI ArcView GIS 3.0 (Figura 5).

A partir da base cartográfica, foram gerados os seguintes mapas da microbacia:

- Carta dos tipos de solos: foi realizado um levantamento pedológico semidetalhado da área, como descrito em Gracia (2001), que constou das seguintes etapas:

- Obtenção de dados cartográficos e aerofotogramétricos da área.

- Fotointerpretação preliminar das formas de relevo e rede hidrográfica como estudo prévio para delimitar as unidades de mapeamento.

- Elaboração de um roteiro de campo de forma a observar todas as unidades fisiográficas. 
- Foram feitas observações de solos, mediante tradagem, dos horizontes superficial (0 $-20 \mathrm{~cm}$ ) e sub-superficial $(80 \mathrm{a} 100 \mathrm{~cm}$ ) em 31 pontos pré-definidos. Cada ponto foi georreferenciado com GPS, e caracterizado o relevo, uso, situação topográfica (topo, terço superior, médio ou inferior, baixada), a cor com uso da carta de cores de Munsell e outras características como teor de ferro e presença de rochas também foram anotadas.

- Interpretação dos resultados analíticos de acordo com EMBRAPA (1999).

- Fotointerpretação final.

- Confecção da carta de solos: os limites das unidades de solo mapeadas foram digitalizados em tela sobre o plano do mosaico formado pelas fotografias aéreas (2000), para constituir o plano de informação solo. Foi elaborado com visualização no SIG ENRI ArcView GIS 3.0.

- Carta de declividade (escala 1:10.000): corresponde aos valores do modelo digital de elevação (MDE) gerado por interpolação das isolinhas altimétricas e dos pontos cotados.

- Carta de uso e ocupação atual do solo (escala 1 : 10.000): elaborados através de informações adquiridas junto aos produtores rurais, levantamentos de campo e fotografias aéreas em escala $1: 30.000$ do ano de 2000. Os polígonos referentes aos diferentes usos do solo foram digitalizados diretamente na tela do computador sobre o mosaico formado com as fotografias aéreas, usando o SIG ENRI ArcView GIS 3.0.

- Carta da vegetação e carta de localização das Áreas de Preservação Permanente (APP) (escala 1: 10.000): foram analisados todos os remanescentes de vegetação natural presentes na Microbacia do Ribeirão São João, tanto em áreas de preservação permanente como fora delas.

Inicialmente foi realizada a digitalização de fotos aéreas obtidas em 2000 (BASE -levantamento aerofotográfico, escala 1:30.000, outubro / 2000). Posteriormente com o 
uso do Auto desk AUTOCAD 2000 as imagens digitalizadas foram analisadas para definição da localização, tamanho, forma e área de todos os fragmentos remanescentes de vegetação, sendo feita também uma separação dos fragmentos observados em grupos, de acordo com a textura e cor observada nas imagens (Rodrigues et al. 2001).

Em seguida, todos os fragmentos reconhecidos foram percorridos e, de acordo com procedimentos convencionais, foi feita a caracterização fisionômica da vegetação, permitindo assim identificar a qual formação vegetal ela pertence, de acordo com a classificação do IBGE (1992). Nessa fase foi feita uma comparação entre a classificação prévia dos fragmentos, baseada na textura e cor da imagem, e a classificação fisionômica, de maneira a permitir uma eventual compatibilização entre ambas, para a definição do mapa de vegetação atual da microbacia .

A etapa seguinte foi a correção da carta, que consistiu na elaboração da carta final de vegetação, utilizando o Auto desk AUTOCAD 2000. Após essa correção, os diferentes tipos vegetacionais foram convertidos para "Shapes" do SIG ENRI ArcView GIS 3.0, onde todas informações e detalhamentos obtidos pela fotointerpretação e checagem de campo foram analisadas.

Utilizando a carta de uso atual do solo e a carta de tipos vegetacionais foram delimitadas as Áreas de Preservação Permanente da microbacia, a partir do leito maior sazonal dos cursos d' água, considerando todas as cartegorias de APP abrangidas pelo artigo $2^{\circ}$ do Código Florestal Brasileiro. Com isso toda a Área de Preservação Permanente foi classificada nas seguintes categorias:

- $\quad$ Áreas a restaurar em APP;

- $\quad$ Remanescentes naturais em APP.

Os remanescentes naturais fora de APP também foram incluídos neste levantamento, pois representam a possibilidade de serem considerados reserva legal, sob o ponto de vista da microbacia (mesoescala) ou da propriedade rural (microescala).

Em seguida foi realizada a classificação das áreas em isoladas (distância $>50 \mathrm{~m}$ ) e não isoladas (distância $<50$ m) (Bertoncini, 2003) de fragmentos florestais.

Visando adequar-se às novas perspectivas de recuperação de áreas degradadas que consideram o paradigma do "Não Equilíbrio" (Pickett \& Ostfeld, 1995) foi feita a 
caracterização das Áreas de Preservação Permanentes para a definição e mapeamentos das áreas que se encontram preservadas e degradadas (Quadro 5), de acordo com a metodologia de Rodrigues et al (2001), que tem o objetivo de subsidiar as futuras prescrição das ações de recuperação a serem implementadas nas Áreas de Preservação Permanentes, de acordo com as propostas de Rodrigues \& Gandolfi (1998).

\begin{tabular}{|c|c|c|c|}
\hline Tipo de formação & $\begin{array}{c}\mathbf{N}^{\mathbf{0}} \text { de } \\
\text { estratos }\end{array}$ & $\begin{array}{c}\text { Estratos } \\
\text { contínuos }\end{array}$ & $\begin{array}{c}\text { Presença de lianas } \\
\text { em desequilíbrio }\end{array}$ \\
\hline Floresta muito degradada & 1 & não & Grande \\
\hline Floresta degradada & $>1$ & não & Média \\
\hline Floresta pouco degradada & $>1$ & sim & baixa \\
\hline
\end{tabular}

Quadro 5 - Critérios para classificação do estado de degradação dos fragmentos florestais da Microbacia do Ribeirão São João (Rodrigues et al., 2001)

A caracterização das Áreas de Preservação Permanente incluiu o seu mapeamento, de forma semelhante ao feito com os remanescentes de vegetação, a caracterização fisionômica da cobertura atual, a identificação e checagem de campo da localização, tamanho, fator e tipo de impacto.

- Carta de estrutura fundiária (escala 1 : 10.000): elaborada seguindo a mesma metodologia usada para gerar a carta de uso e ocupação do solo. Foram usados levantamentos de campo, informações junto aos produtores rurais e fotografias aéreas em escala 1: 30.000 do ano de 2000, sendo que os polígonos referentes às propriedades rurais foram digitalizados diretamente na tela do computador sobre o mosaico formado com as fotografias aéreas, usando o SIG ENRI ArcView GIS 3.0.

\section{Diagnóstico e Planejamento Participativos}

O planejamento do manejo integrado de microbacias hidrográficas, somente será completo se houver participação da população envolvida ou com interesses locais. 
Tendo como base os mapas produzidos, os dados socioeconômicos extraídos do Projeto LUPA (Levantamento Censitário das Unidades de Produção Agropecuária) e os dados do Levantamento Socioeconômico e Ambiental, juntamente com a comunidade, foram elaborados o diagnóstico e planejamento participativos, a partir do qual foi possível planejar, com a participação ativa da comunidade, as ações a serem implementadas na Microbacia Hidrográfica do Ribeirão São João.

Para isso, foram realizadas duas reuniões, sendo que na primeira, com a presença dos produtores rurais da microbacia e seus familiares, dos membros do Conselho Municipal de Desenvolvimento Rural de Mineiros do Tietê, do prefeito e vereadores e das professoras das escolas públicas municipais, o Programa Estadual de Microbacias Hidrográficas (PEMBH), isto é, seus objetivos, premissas, incentivos, estrutura e estratégias, foram apresentados de maneira detalhada, por um dirigente do programa. Em seguida, o Presidente do Conselho Municipal de Desenvolvimento Rural e também produtor da microbacia, apresentou um histórico da agricultura do local.

No dia seguinte, foi realizado um caminhamento pela microbacia com os produtores rurais, isto é, um compartilhamento visual ou leitura de paisagem, para se incentivar a visualização da dinâmica da microbacia, seus divisores de águas, suas nascentes, sua área e diferentes usos, os problemas associados e potenciais de desenvolvimento. Esta prática teve o objetivo de facilitar as discussões, a participação e a expressão dos produtores nas questões referentes ao seu ambiente.

$\mathrm{Na}$ segunda reunião, com a presença apenas dos produtores rurais da microbacia e seus familiares, foram elaborados o diagnóstico e o planejamento participativos. As pessoas foram organizadas em vários pequenos grupos, para cada um deles discutir um tema específico relacionado à microbacia: infraestrutura (escola, estrada, eletricidade, etc), produção agrícola (diversidade, produtividade, comercialização, etc), meio ambiente (preservação, impactos, degradação, etc) e aspectos sociais (saúde, educação, etc). Logo após, um grupo único com todos os presentes foi formado e, então, iniciada a discussão sobre os vários problemas identificados na microbacia, os anseios da comunidade, os fatores que facilitam ou dificultam as soluções, as ações e os 
responsáveis para o desenvolvimento das medidas determinadas pelos participantes para eliminar ou amenizar os problemas e alcançar a satisfação dos seus anseios.

Assim, foram elaborados o Diagnóstico e o Planejamento Participativos, que embora sejam atividades desenvolvidas normalmente pelas Casas da Agricultura dos municípios que implementam o Programa Estadual de Microbacias Hidrográficas, neste caso, foram realizados de maneira a seguir uma metodologia diferenciada para a obtenção de resultados esperados para este trabalho.

Essas práticas foram baseadas em recomendações de Geilfus (1997) para o "Projecto Regional de Desarrollo Institucional para la Producción Agrícola Sostenible em lãs Laderas de Centroamérica”.

Embora a participação da comunidade local seja uma questão vital para o planejamento ambiental, que o torna legítimo e com maiores possibilidades de sucesso, representando a garantia de que as medidas estabelecidas para o manejo agrícola e para a proteção e restauração ambiental sejam respeitadas, na prática sua inserção no processo representa um grande desafio. $\mathrm{O}$ amadurecimento da participação requer constantes encontros e técnicas para que ela seja realmente efetiva, espontânea e expresse o conhecimento, as experiências e os anseios da população local.

Existem vários graus e condicionantes para a participação. Os participantes podem tomar parte do processo desde uma foram aparente e superficial e até manipulada, sem poder real de decisão, até de uma maneira efetiva, com interatividade e automobilização. Quanto às condicionantes, é importante que a comunidade tenha um pré-entendimento dos objetivos, dos fatos, dos fenômenos e dos cenários; credibilidade no processo; condições de deliberação e escolha; consenso mínimo sobre conceitos específicos e representação social, para que no final ocorra reflexão coletiva consciente para os problemas que se apresentam (Santos, 2003).

O processo de diagnóstico e planejamento participativos para a Microbacia do Ribeirão São João ainda está em sua primeira fase, sem um amadurecimento ideal, entretanto seus resultados devem ser considerados para as próximas fases, além disso, podem validar a importância da construção do cenário alternativo, objetivo desta pesquisa. 


\subsubsection{Integração dos dados para a composição dos cenários convencionais (sem inclusão da zona ripária) e alternativos (com inclusão da zona ripária) e comparação dos riscos estabelecidos a partir de cada cenário}

Após a revisão bibliográfica baseada em preceitos de agricultura sustentável, a caracterização dos aspectos agrícolas, ecológicos e socioeconômicos da Microbacia Hidrográfica do Ribeirão São João e o diagnóstico e planejamento participativos, o objetivo deste trabalho foi o de oferecer uma proposta de adequação do uso do solo e caracterização dos riscos ambientais, por meio da apresentação de cenários.

A construção dos cenários foi desenvolvida em etapas, sendo iniciada com o diagnóstico da situação atual ou caracterização da área, análise das mútuas influências entre as variáveis ou temas analisados e montagem dos cenários alternativos, através da sobreposição das cartas temáticas elaboradas.

\section{Descrição dos cenários convencionais (sem inclusão da zona ripária)}

Foram construídos os cenários convencionais, isto é, os que consideram a adequação do uso do solo através de análise das classes de capacidade de uso e os que consideram o potencial natural de erosão e o risco de erosão para avaliação de áreas sensíveis ao desenvolvimento de processos erosivos em microbacias.

Para a construção dos cenários convencionais foram elaboradas as seguintes cartas temáticas com o diagnóstico da situação atual, caracterização da área e análise das relações entre os temas analisados e em seguida foram construídos os cenários:

- Carta de classes de capacidade de uso da terra (escala $1: 10.000$ ): as classes de capacidade de uso do solo da microbacia foram mapeadas com a utilização do software Idrisi, (Clark labs IDRISI 2 for Windows) através do cruzamento dos dados contidos nos planos de informação de solo e declividade. Para a determinação das classes de capacidade de uso, adotou-se o sistema de classificação convencional aceito universalmente e adaptado por Lepsch et al. (1983). 
Esta classificação é composta de oito classes distribuídas em três subdivisões (Lepsch, 2002; Bertoni \& Lombardi Neto,1990), que considera:

Grupo A - Terras próprias para todos os usos, incluindo cultivos intensivos:

1. Classe I: terras com pequenas limitações referentes à erosão, podendo ser cultivadas. Os solos são profundos, produtivos, fáceis de trabalhar e conservam bem a água. Os terrenos têm declividade suave, podendo ser cultivados sem práticas especiais de controle da erosão. Não são susceptíveis a inundações, mas estão sujeitos à lixiviação (movimento vertical da lavagem) e à deterioração da estrutura (compactação).

2. Classe II: terras com limitações moderadas de uso e que apresentam moderados riscos de degradação. Estão em áreas ligeiramente inclinadas, propensas à erosão ou naturalmente encharcadas. Podem necessitar de práticas simples de conservação como plantio em nível, plantas de cobertura ou métodos de cultivo especiais, como o plantio direto.

3. Classe III: terras também apropriadas para cultivos intensivos, mas que requerem práticas complexas de conservação.Apresentam áreas com declives mais acentuados, com maiores riscos de erosão e limitações edáficas.

4. Classe IV: terras onde não são recomendáveis cultivos regulares e as culturas anuais se tornam apropriadas apenas por curtos períodos, quando adequadamente protegidas. Possuem declividade íngrime, erosão severa, drenagem muito deficiente, baixa produtividade ou qualquer outra condição que a torna imprópria para o cultivo.

Grupo B - Terras impróprias para cultivos intensivos, a não ser em casos especiais de algumas culturas permanentes, mas aptas para pastagens e reflorestamento ou manutenção da vegetação natural: 
5. Classe V: terras que devem ser mantidas com pastagem ou reflorestamento, ou algumas culturas perenes. São terras praticamente planas, com problemas de encharcamento ou afloramento de rochas.

6. Classe VI: terras adaptadas à pastagem ou reflorestamento ou cultivos especiais de culturas perenes. Apresentam problemas de pouca profundidade do solo ou declividade excessiva. Quando usadas com pastagem requerem cuidados para evitar a erosão.

7. Classe VII: terras que apresentam severas limitações até mesmo para pastagens e reflorestamento. Requerem cuidados extremos para controle da erosão.

Grupo C - Terras impróprias para cultivos, recomendadas para proteção da fauna, flora, armazenamento de água ou recreação:

8. Classe VIII: São áreas muito áridas, declivosas, pedregosas, arenosas, encharcadas ou erodidas como, por exemplo, encostas com afloramentos rochosos, terrenos íngremes montanhosos e mangues.

- Carta de adequação do uso da terra (escala 1: 10.000): foi obtido a partir da combinação do plano de informação de uso e ocupação do solo com o de classes de capacidade de uso, com o objetivo de obter a relação entre o uso atual e a capacidade ambiental dos diferentes agroecossistemas da microbacia. Foram utilizadas três categorias, segundo Brandão (2001):

1. classe com uso adequado: equilíbrio entre o uso atual e as possibilidades e limitações da terra,

2. classe com subutilização: terras com uso atual abaixo da capacidade ambiental,

3. classe com sobreutilização: terras com uso atual acima da capacidade ambiental.

Assim, a subutilização, isto é, a ocupação de áreas de, por exemplo, classe de capacidade de uso I ou II, recomendadas para culturas anuais, estando usadas com 
pastagens, indicaria uma condição socialmente inconveniente. Da mesma forma, a situação oposta, indesejável do ponto de vista ecológico, é a utilização com lavouras de ciclo curto ou semi perenes de terras com indicação para uso com silvicultura ou pastagens.

- Carta de potencial natural de erosão e carta de risco de erosão (escala 1 : 10.000): o potencial natural de erosão, definido pelos fatores da Equação Universal de Perda de Solos que representam os parâmetros do meio físico (erosividade, erodibilidade e fator topográfico), é expresso pela fórmula:

$$
\mathrm{PNE}=\mathrm{R} \times \mathrm{K} \times \mathrm{LS}
$$

onde:

PNE $=$ Potencial natural de erosão

$\mathrm{R}$ = erosividade (fator $\mathrm{R}$ ), representa o potencial erosivo das chuvas para a microbacia e foi obtido segundo Lombardi Neto et al. (2000). Devido ao tamanho relativamente pequeno da microbacia, foi estimado um valor único de erosividade, que corresponde à $6865 \mathrm{MJ} \cdot \mathrm{mm} \cdot \mathrm{ha}^{-1} \cdot \mathrm{h}^{-1}$ para toda a sua área.

$\mathrm{K}$ = erodibilidade (fator $\mathrm{K}$ ), foi determinada para cada tipo de solo (Bertoni \& Lombardi Neto, 1990) e para cada associação de solos (Pereira, 2002; Lagrotti, 2000).

LS = fator topográfico, calculado pela equação desenvolvida por Bertoni \& Lombardi Neto (1990):

$$
\mathrm{LS}=0,00984 \times \mathrm{C}^{0,63} \times \mathrm{D}^{1,18}
$$

onde:

$$
\mathrm{C}=\text { comprimento de rampa (metros) e } \mathrm{D}=\text { declividade (porcentagem). }
$$

A declividade corresponde aos valores do modelo digital de elevação gerado por interpolação das isolinhas altimétricas e dos pontos cotados pelo "software" Surfer e posteriormente transformado em porcentagem utilizando o software Idrisi (Clark labs IDRISI 2 for Windows). Os valores para o comprimento de rampa foram obtidos pela 
aplicação da metodologia desenvolvida por Valeriano (1999), com o software Idrisi (Clark labs IDRISI 2 for Windows).

Depois de calculado o potencial natural de erosão foi realizada uma classificação de acordo com Gracia (2001), como exposto no Quadro 6.

\begin{tabular}{|c|c|}
\hline Classes & Valores (Mg.ha' ${ }^{-1} \cdot$ ano $^{-1}$ ) \\
\hline muito baixa & $<500$ \\
\hline baixa & $500-1000$ \\
\hline moderada & $1000-2000$ \\
\hline alta & $2000-5000$ \\
\hline muito alta & $>5000$ \\
\hline
\end{tabular}

Quadro 6- Classes do potencial natural de erosão da Microbacia do Ribeirão São João

(Gracia, 2001)

O risco de erosão, determinado com base no trabalho de Donzeli et al. (1992), considerou os valores de perdas toleráveis para cada unidade de solo e os valores do potencial natural de erosão para determinar as classes de uso-manejo permissível (condicionantes do risco de erosão) relacionadas à capacidade de uso das terras, e a prática mínima de plantio em nível $(\mathrm{P})$, conforme a equação:

$\mathrm{UMP}=\mathrm{T} / \mathrm{PNE} . \mathrm{P}$

sendo:

$\mathrm{UMP}=$ risco de erosão (capacidade de uso-manejo permissível);

$\mathrm{T}=$ perdas permissíveis para cada unidade de solo;

$\mathrm{PNE}=$ potencial natural de erosão;

$\mathrm{P}=$ práticas conservacionistas $(\mathrm{P}=$ plantio em nível, variável com a declividade $)$ (Quadro 7). 


\begin{tabular}{|c|c|}
\hline Declividade (S) & Valores de P \\
\hline $\mathrm{S} \leq 3 \%$ & 0,60 \\
\hline $3 \%<\mathrm{S} \leq 6 \%$ & 0,50 \\
\hline $6 \%<\mathrm{S} \leq 9 \%$ & 0,60 \\
\hline $9 \%<\mathrm{S} \leq 12 \%$ & 0,80 \\
\hline$>12 \%$ & 1,00 \\
\hline
\end{tabular}

Quadro 7- Dados de valores do fator P, conforme a declividade, considerando-se o plantio em nível

Depois de calculado o risco de erosão foi realizada uma classificação de acordo com Donzeli et al. (1992), como exposto no Quadro 8.

\begin{tabular}{|c|c|}
\hline \multicolumn{2}{|c|}{ Risco de erosão } \\
\hline Classes & Valor UMP $*$ \\
\hline Baixo & $>0,02$ \\
\hline Moderado & $0,02-0,01$ \\
\hline Alto & $<0,01$ \\
\hline
\end{tabular}

* Valores de uso manejo permissível, relacionados ao fator C da Equação Universal de Perdas de Solo para classificação de capacidade de uso das terras.

Quadro 8 - Classes de risco de erosão da Microbacia do Ribeirão São João (Donzeli et al., 1992)

- A construção dos cenários convencionais: após realizada a preparação das cartas temáticas de classes de capacidade de uso da terra, de adequação do uso incluindo a Área de Preservação Permanente prevista na legislação ambiental, de potencial natural de erosão e de risco de erosão, foram estruturados os cenários convencionais conforme mostra a Figura 7. 


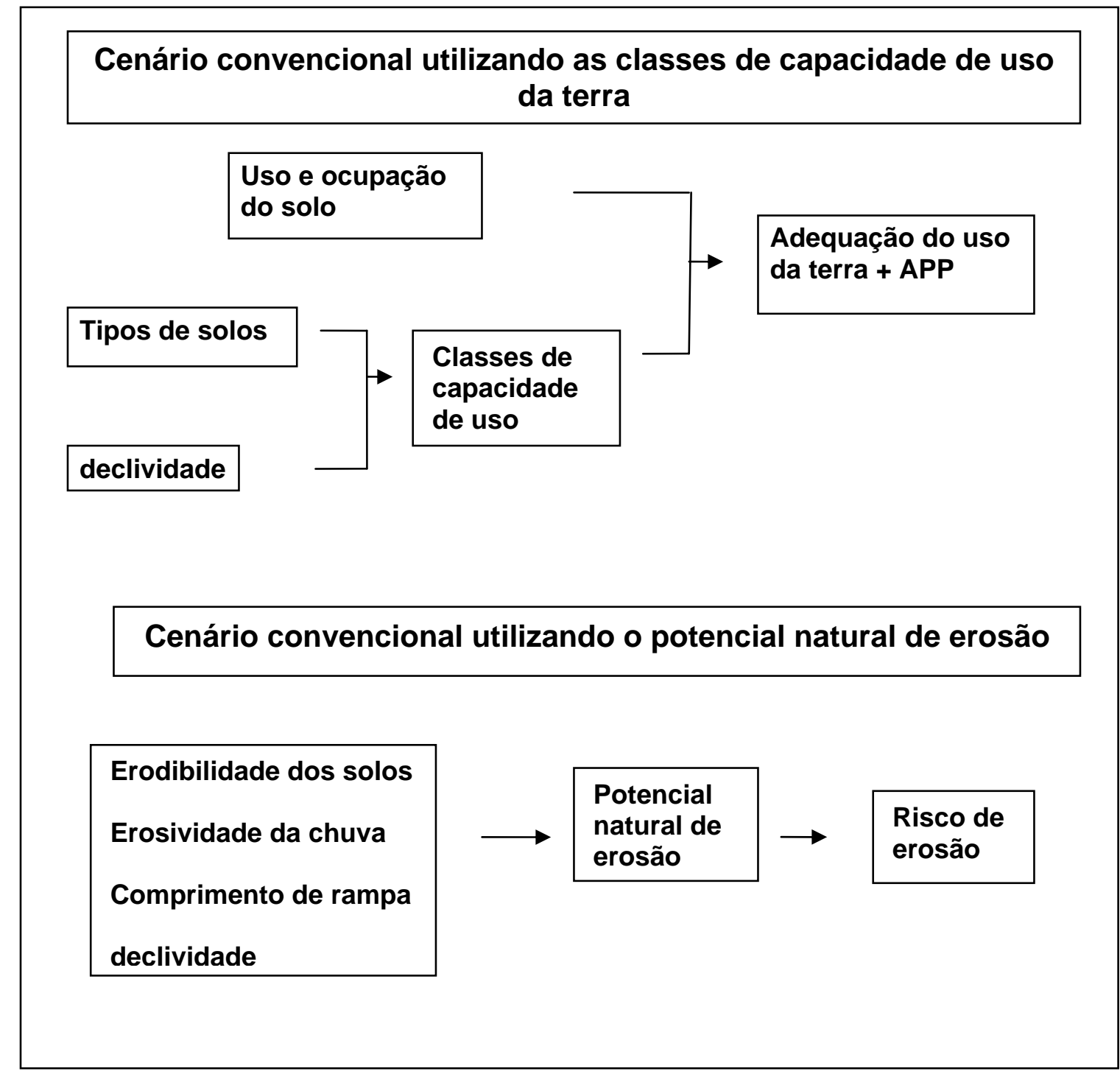

Figura 7 - Fluxograma básico para a construção dos cenários convencionais através da utilização das cartas de classes de capacidade de uso da terra e adequação do uso e das cartas de potencial natural de erosão e risco de erosão

\section{Descrição dos cenários alternativos (com inclusão da zona ripária)}

Os cenários que representam uma proposta alternativa para os planos de manejo integrado de microbacias, foram construídos através da inserção da delimitação e avaliação da zona ripária nos cenários convencionais, o que permite a identificação das 
áreas da microbacia que têm função de proteção e as áreas cujo manejo agrícola deveria ser diferenciado, sob a ótica da hidrologia. Para isto foi preciso a elaboração das seguintes cartas temáticas com o diagnóstico da situação atual, caracterização hidrológica da área e análise das relações entre as variáveis analisadas e, finalmente, a construção dos cenários alternativos:

- Carta de identificação das Áreas Variáveis de Afluência (escala 1: 10.000): está carta foi elaborada segundo metodologia descrita em Zakia (1998), conforme mostra a Figura 8. Em uma primeira etapa, foi elaborado o Modelo Digital do Terreno (MDT), pela interpolação das curvas de nível e pontos de cota pelo método TIN (Triangulated Irregular Network), utilizando o SIG ENRI ArcView GIS 3.0. Em seguida, o MDT restrito à área da microbacia foi exportado no formato ASCII, afim de preparar os dados para utilização no programa AVA.EXE. Foram usados o Word e o Excell para alterar o arquivo do cabeçalho. Após rodar no AVA.EXE, o arquivo AVA foi preparado para visualização no SIG ENRI ArcView GIS 3.0, com a utilização do Word para voltar o cabeçalho original. O arquivo foi importado no formato ASCII e, finalmente, foi estabelecida a delimitação da área variável de afluência, que é uma zona ripária, na microbacia. 


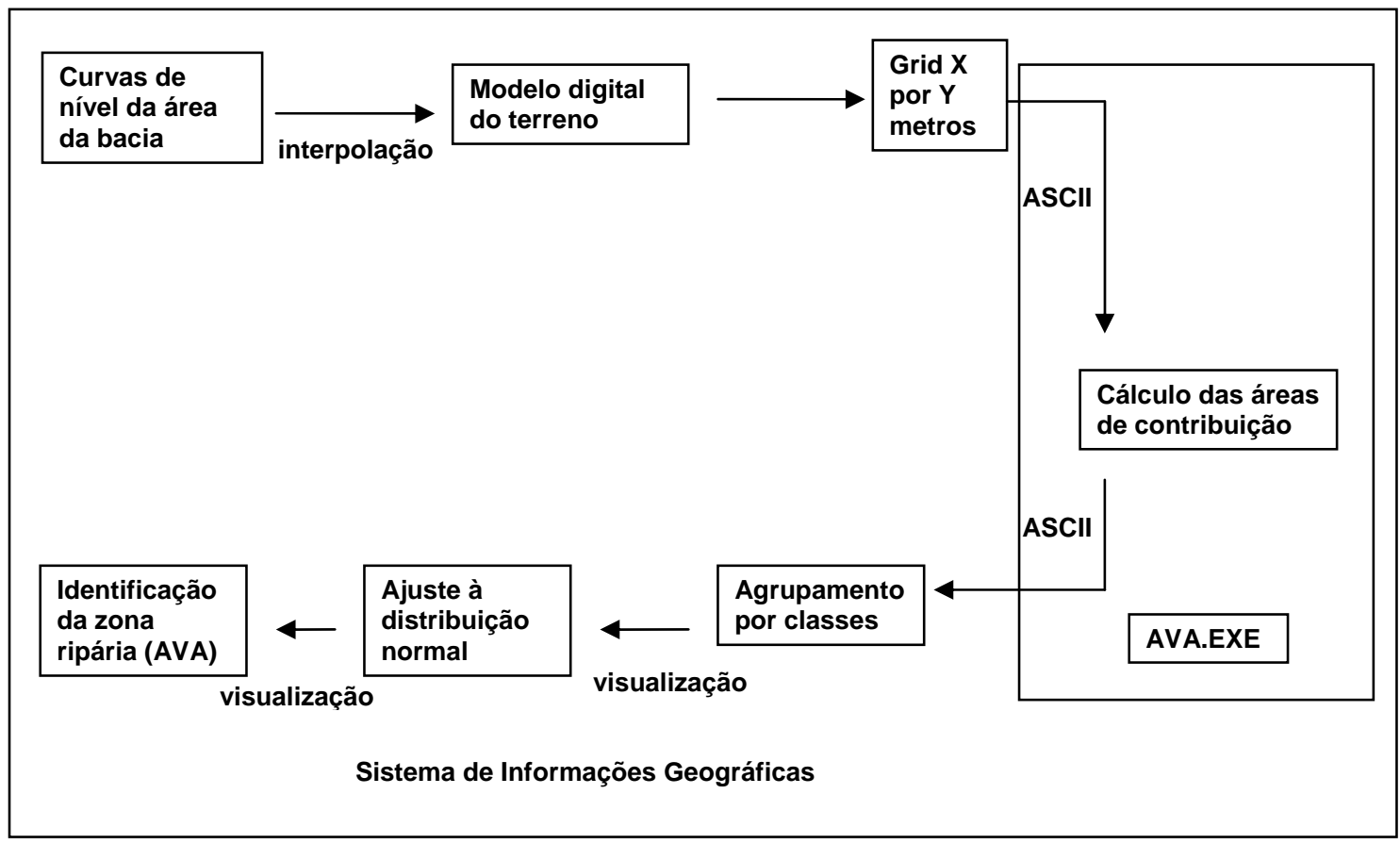

Figura 8- Metodologia desenvolvida / adaptada para a identificação da área variável de afluência (Zakia, 1998)

- Carta de Zona Ripária (escala 1: 10.000): a metodologia para identificação da AVA na microbacia, por ser baseada em acumulação de pixels, ou seja, cada célula da bacia possui uma área de contribuição drenando para aquele ponto, não é suficiente para delimitação da zona ripária em locais planos. Desta forma, o levantamento dos tipos vegetacionais ao identificar as várzeas, banhados e florestas paludosas, vegetações típicas de áreas planas e saturadas, auxilia na complementação de informações para a localização da zona ripária. A carta de zona ripária é, então o resultado da combinação dos planos de informação de Área Variável de Afluência, que representa a zona ripária em áreas declivosas, com o de vegetação considerando apenas as florestas com influência fluvial temporária ou permanente (Florestas Paludosas, as Florestas Ribeirinhas e os campos úmidos), presentes em áreas planas e reconhecidamente diferenciadas do ponto de vista hidrológico e vegetacional. 
- A construção dos cenários alternativos: representa a inclusão da zona ripária nos cenários convencionais, para a determinação da adequação do uso do solo e dos riscos ambientais na microbacia. Para isto, a carta de zona ripária foi sobreposta à carta de classes de capacidade de uso e à carta de potencial natural de erosão inserindo a Área de Preservação Permanente, para, em seguida, apresentar a análise de adequação de uso do solo e dos riscos de erosão, considerando a inclusão da zona ripária nesta análise, conforme estrutura mostrada na Figura 9.

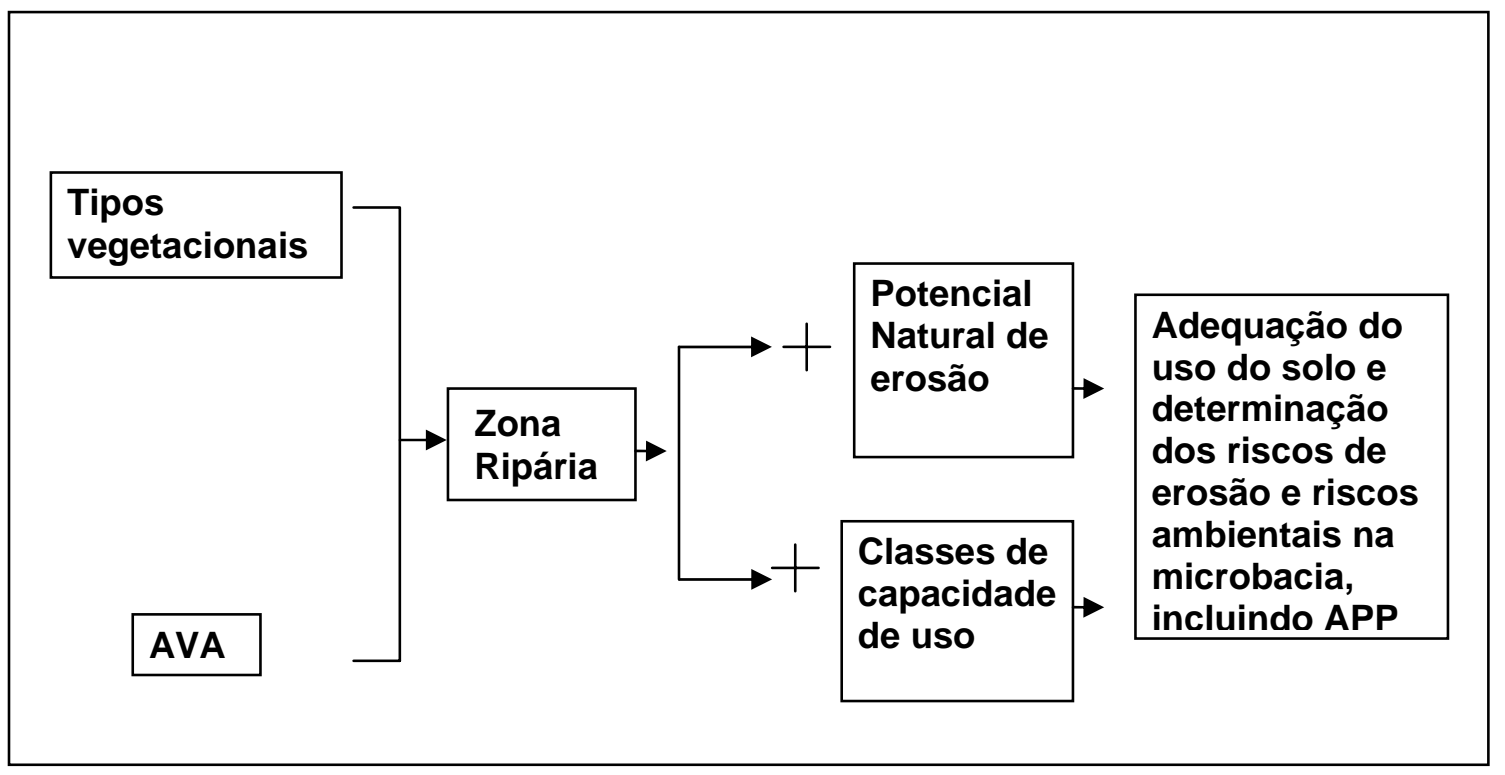

Figura 9 - Cenário alternativo mostrando a inclusão da zona ripária nas análises que utilizam as classes de capacidade de uso e o potencial natural de erosão, com a inserção da Área de Preservação Permanente, para a determinação da adequação o uso do solo, riscos de erosão e riscos ambientais na microbacia

Para discutir as relações entre o cenário que inclui a zona ripária e a legislação ambiental (Área de Preservação Permanente, Reserva Legal), a distribuição da estrutura fundiária e o uso e manejo agrícola, foram feitas as seguintes cartas e levantamentos correlacionando alguns temas: 
- Carta de zona ripária incluindo Área de Preservação Permanente e carta de zona ripária x vegetação: resultantes da combinação do plano de informação de zona ripária com o de Área de Preservação Permanente e o de tipos vegetacionais respectivamente, permitindo a discussão a respeito de aspectos relacionados à legislação ambiental e à proteção da zona ripária.

- Carta de zona ripária incluindo estrutura fundiária: elaborada a partir da sobreposição das cartas de zona ripária e de estrutura fundiária, com o objetivo de embasar questões com enfoque socioeconômicos e ambientais.

- Combinação de dados referentes à zona ripária, uso atual do solo e manejo agrícola na microbacia: possibilita o reconhecimento dos tipos de ocupação do solo em áreas de zona ripária, correlacionando o manejo das explorações agropecuárias e os riscos de degradação da zona ripária.

- Carta de zona ripária incluindo estrutura fundiária, curvas de nível e estradas rurais: elaborada através da combinação das cartas de zona ripária, estrutura fundiária, curvas de nível e estradas rurais para permitir estudo sobre a adequação da localização das estradas da microbacia, identificação dos trechos mal localizados, que atravessam a zona ripária, e apresentação de proposta de localização apropriada, considerando apenas os princípios hidrológicos. 


\section{RESULTADOS E DISCUSSÃO}

4.1 Base de dados descritivos dos aspectos agrícolas, ecológicos e socioeconômicos da microbacia do Ribeirão São João (Mineiros do Tietê, SP), necessários à composição dos cenários

\subsubsection{Carta Básica}

A Figura 10 apresenta a carta básica da Microbacia do Ribeirão São João, incluindo o limite de sua área (3.656 ha), a rede hidrográfica, as estradas rurais, a localização do município de Mineiros do Tietê e as curvas de nível com equivalência vertical de 5 metros. O perímetro da microbacia tem aproximadamente $33 \mathrm{~km}$ e a rede de drenagem $47 \mathrm{~km}$. 


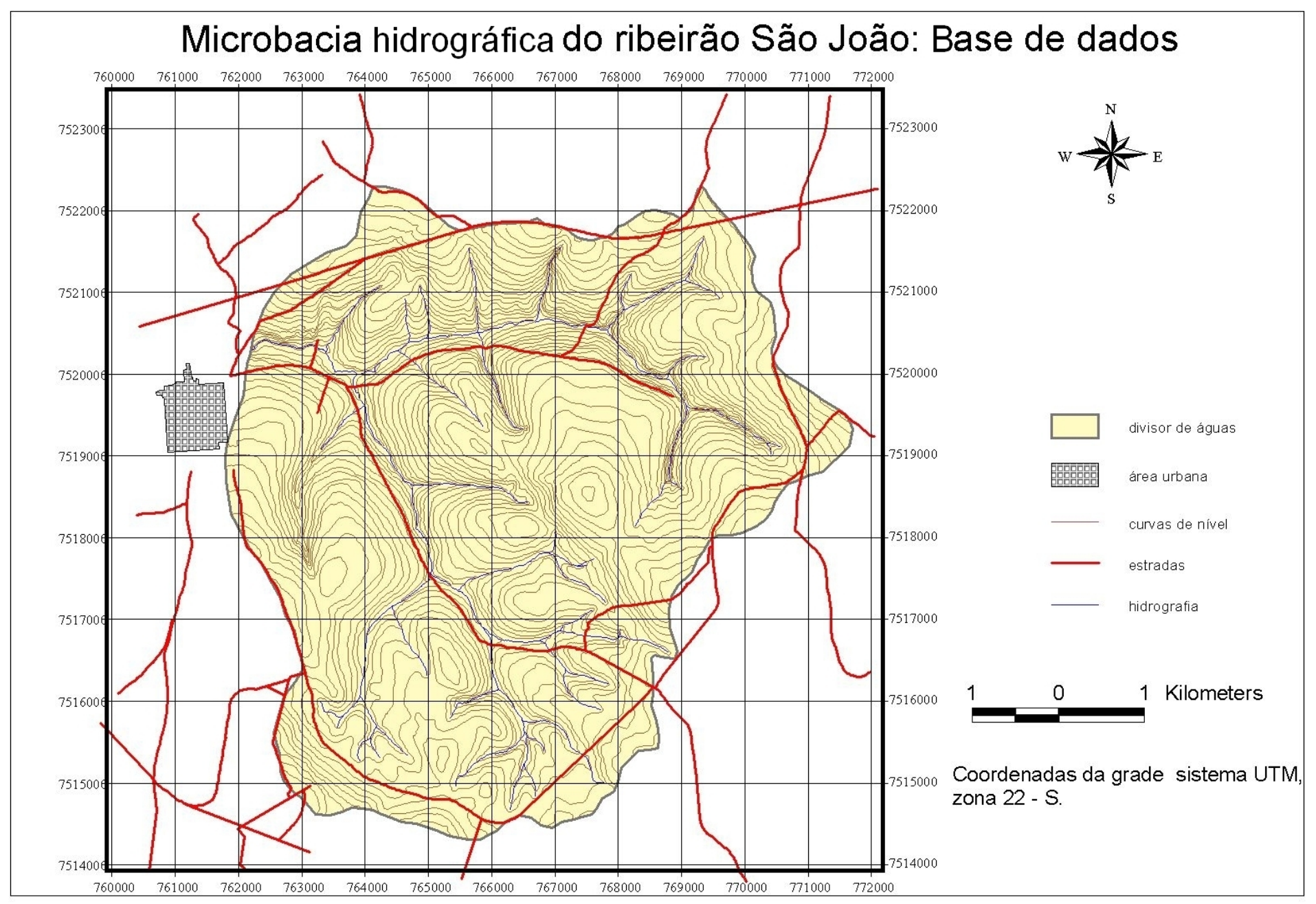

Figura 10 - Mapa base da microbacia hidrográfica do Ribeirão São João (Mineiros do Tietê, SP) formada pelo Córrego do Borralho (ao norte) e Ribeirão São João. Ano: 1980 


\subsubsection{Tipos e associações de solos}

A carta de solos foi obtida através do levantamento pedológico semidetalhado da microbacia do Ribeirão São João, o que proporcionou melhor qualidade e especificidade dos dados em relação às informações gerais encontradas no Levantamento Pedológico Semidetalhado do Estado de São Paulo realizado pelo Instituto Agronômico de Campinas (Almeida et al., 1981). Entretanto, este Levantamento Pedológico Semidetalhado se mostra bastante útil em situações onde não é possível a obtenção de informações mais detalhadas da área estudada.

O conhecimento sobre os solos da microbacia é a base para a confecção de outras cartas como, por exemplo, a carta de classes de capacidade de uso e de potencial natural de erosão, e para as recomendações de manejo agrícola.

O solo Latossolo Vermelho Amarelo (LV2) predomina na microbacia, ocupando 55,6 \% de sua área. No Quadro 9 estão descritas as associações e unidades de solo da microbacia e a área que ocupam e na Figura 11 sua distribuição espacial. 


\begin{tabular}{|c|c|c|c|c|}
\hline Solos & $\begin{array}{c}\text { Descrição } \\
\text { Camargo et al, } 1987\end{array}$ & $\begin{array}{c}\text { Descrição } \\
\text { EMBRAPA, } 1999\end{array}$ & $\begin{array}{l}\text { Área } \\
\text { (ha) }\end{array}$ & $\begin{array}{l}\text { Área } \\
(\%)\end{array}$ \\
\hline LVa & 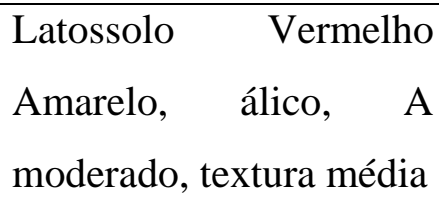 & $\begin{array}{l}\text { Latossolo Vermelho Amarelo } \\
\text { distrófico típico, álico, A } \\
\text { moderado, textura média }\end{array}$ & $2.032,7$ & 55,6 \\
\hline $\mathrm{LRe}+\mathrm{LRd}$ & $\begin{array}{l}\text { Latossolo } \\
\text { eutrófico, A moderado } \\
\text { ou chernozênico } \\
\text { Latossolo } \\
\text { distrófico, A moderado } \\
\text { ou proeminente }\end{array}$ & $\begin{array}{l}\text { Latossolo Vermelho } \\
\text { eutroférrico, A moderado ou } \\
\text { chernozênico + Latossolo } \\
\text { Vermelho distroférrico, A } \\
\text { moderado ou proeminente }\end{array}$ & 614,2 & 16,8 \\
\hline PVd & $\begin{array}{l}\text { Podzólico } \\
\text { Amarelo, argila de } \\
\text { atividade } \\
\text { distrófico, A moderado, } \\
\text { textura média ou } \\
\text { arenosa/média }\end{array}$ & $\begin{array}{l}\text { Argissolo Vermelho Amarelo } \\
\text { distrófico, A moderdo, } \\
\text { textura média ou } \\
\text { arenosa/média }\end{array}$ & 570,4 & 15,6 \\
\hline NVef & $\begin{array}{l}\text { Terra Roxa Estruturada } \\
\text { eutrófica A moderado } \\
\text { textura muito argilosa }\end{array}$ & $\begin{array}{l}\text { Nitossolo } \\
\text { eutroférrico A moderado } \\
\text { textura muito argilosa }\end{array}$ & 365,6 & 10,0 \\
\hline $\mathrm{GH}$ & $\begin{array}{l}\text { Glei Pouco Húmico } \\
\text { textura média }\end{array}$ & $\begin{array}{l}\text { Gleissolo Háplico textura } \\
\text { média }\end{array}$ & 73,1 & 2,0 \\
\hline TOTAL & & & 3.656 & 100 \\
\hline
\end{tabular}

Quadro 9 - Descrição das associações e unidades de solo presentes na microbacia do Ribeirão São João 


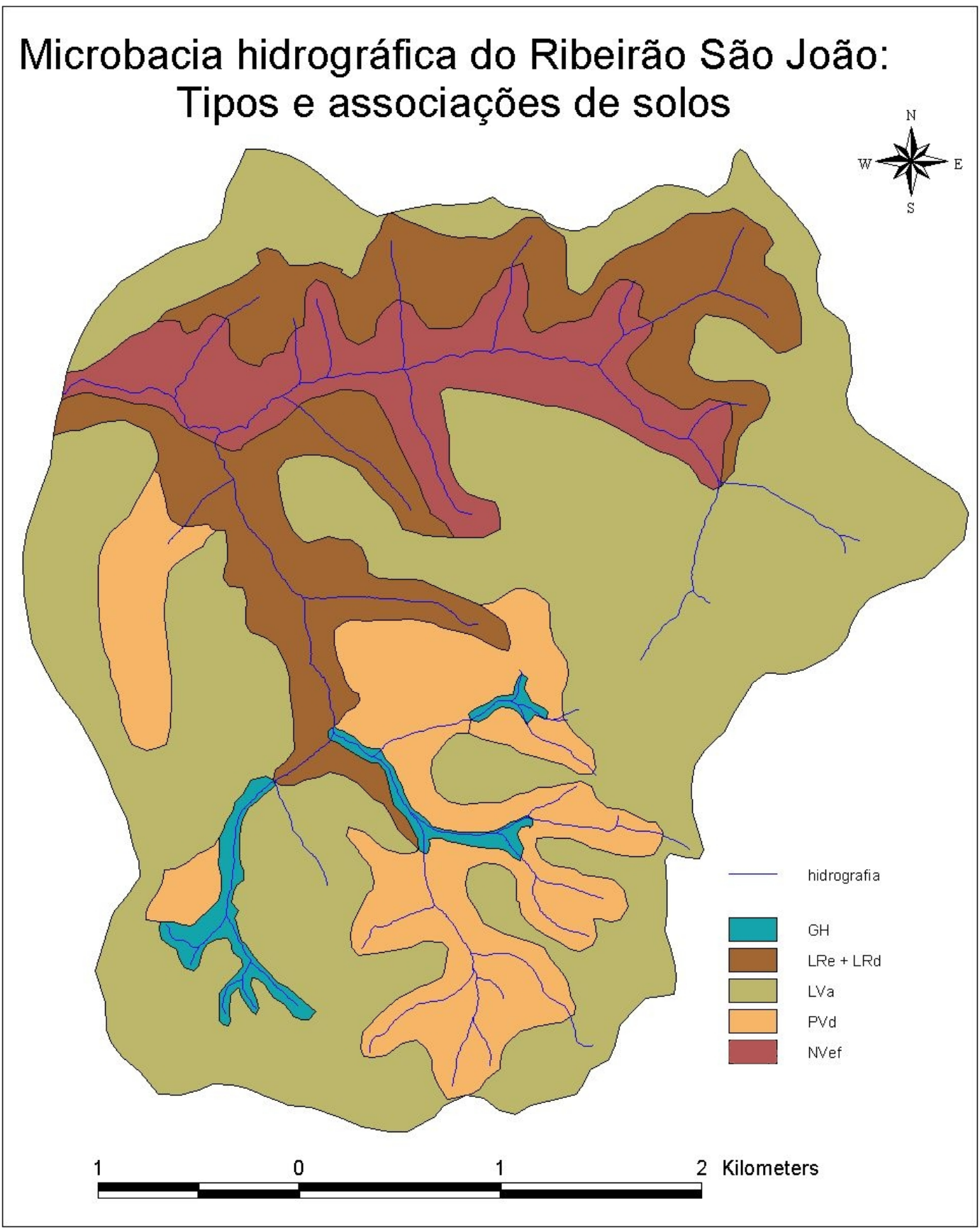

Figura 11 - Solos e associações de solos (Gleissolo Háplico, Latossolo Vermelho eutroférrico + Latossolo Vermelho distroférrico, Latossolo Vermelho Amarelo distrófico típico, Argissolo Vermelho Amarelo distrófico, Nitossolo Vermelho eutroférrico) da microbacia do Ribeirão São João (Mineiros do Tietê, SP). Ano: 2004 
Segundo Bertolini et al (1994), com o conhecimento dos solos de uma região é possível seu melhor aproveitamento e uma previsão de seu comportamento com relação ao manejo agrícola. Assim, esses autores descrevem as seguintes unidades de solo encontradas na Microbacia do Ribeirão São João:

- Latossolo Vermelho Amarelo (Latossolo Vermelho Amarelo): é um solo profundo, regular a agricultura, com problemas de erosão, embora não em grau elevado. Possui fertilidade baixa, exigindo a aplicação correta de fertilizantes e corretivos;

- Latossolo Roxo ( Latossolo Vermelho eutroférrico ou distroférrico): é muito bom para a agricultura, apresenta pequena restrição à mecanização, pouco perigo de erosão e normalmente boa fertilidade;

- Podzólico Vermelho-Amarelo (Argissolo Vermelho Amarelo): apresenta nítida diferenciação textural entre os horizontes A e B e baixa saturação em base. É considerado regular para agricultura, pois tem problemas de fertilidade, de erosão e mecanização. Por isso, é exigente em práticas conservacionistas, simples e intensivas. Quando sob pastagem, apresenta risco de ser erodido, dependendo da declividade do terreno.

- Terra Roxa Estruturada (Nitossolo Vermelho eutroférrico): sua textura é argilosa tanto no horizonte A como no B. Há abundância de minerais pesados que se depositam nos leitos de drenagem superficial, com aspecto de limalha de ferro. É considerado bom para agricultura, apresentando apenas problemas de erosão e, em alguns casos, impedimentos à motomecanização.

- Hidromórficos “Gleizados” (Gleissolo Háplico): esta unidade reúne solos minerais de várzeas, caracterizados pela saturação com água durante a maior parte do ano resultando em acúmulo de matéria orgânica no horizonte superficial e "gleização” nos horizontes subjacentes. Apresenta uso regular para agricultura, com problema de drenagem deficiente e risco de inundação, mas ao ser drenado, torna-se aproveitável, com restrição à fertilidade e ao uso de máquinas agrícolas. Embora não mencionado pelos autores, esses solos apresentam-se em Áreas de Preservação Permanente, sendo seu uso proibido pela legislação ambiental. 
Os solos álicos ocorrem em 55,6 \% da microbacia. São aqueles onde a saturação por alumínio é maior que $50 \%$, desde que $\mathrm{Al}=0,3$ a 4,0 cmol / kg, e pH menor que 5,0, o que deve ser levado em consideração no momento da recomendação de adubação, da correção da acidez do solo e de variedades adequadas aos produtores rurais dessas áreas.

Os solos eutróficos indicam alta saturação por bases (V\%), ou seja, o valor de V é maior que $50 \%$ na maior parte do horizonte $\mathrm{B}$. O pH (em água) é igual ou maior que 5,5 e, portanto, se não houver fatores limitantes ligados à física do solo, esta terra é bastante produtiva, pelo bom suprimento de bases e por não ter problemas de toxicidade de alumínio abaixo da camada arável. Os solos distróficos possuem saturação de bases (V\%) inferior à 50 \% e pH (em água) entre 5 e 5,5, o que pode conferir problemas com fertilidade.

Bertoni \& Lombardi Neto (1990) esclarecem que alguns solos são mais vulneráveis ou susceptíveis à erosão que outros, mesmo quando a chuva, a declividade, a cobertura vegetal e as práticas de manejo são as mesmas. Essa diferença, devido às propriedades inerentes do solo, é chamada de erodibilidade. Essas propriedades do solo, que infuenciam a erodibilidade pela água, são aquelas que afetam a velocidade de infiltração, permeabilidade e capacidade total de armazenamento de água. São também aquelas que resistem às forças de dispersão, salpicamento, abrasão e transporte pela chuva e escoamento. Todos os fatores como intensidade de chuva, manejo agrícola, cobertura vegetal e declividade podem, na verdade, influenciar a intensidade da erosão de uma área mais propriamente do que as características do solo.

Esses mesmos autores afirmam que a erodibilidade é mais influenciada pelo manejo do que por qualquer outro fator, e o melhor manejo do solo pode ser definido como aquele que promove o uso mais intensivo e mais produtivo do solo sem causar degradação.

Cerca de 82,4 \% dos solos da microbacia do Ribeirão São João apresentam valores de erodibilidade baixos, enquanto os restantes 17,6 \%, representados pelo Argissolo Vermelho Amarelo e pelo Gleissolo Háplico, possuem valores altos e muito altos deste fator (Quadro 10,11 e 12). 
A tolerância à perda de solo, outro fator relacionado à erosão, representa a quantidade de terra que pode ser perdida sem alterar o nível econômico de produtividade do solo e por tempo indefinido. Os níveis de tolerância não impõem restrições ao uso e manejo do solo, mas direcionam a escolha das técnicas a serem adotadas (Bertoni \& Lombardi Neto,1990).

Portanto, todas as áreas da microbacia, com seus diversos tipos de solo, irão sofrer degradação se o manejo agrícola não for adequado, possibilitando boa cobertura do solo e a aplicação de práticas reconhecidas como conservacionista. Essas práticas irão promover a infiltração da água da chuva e seu armazenamento no solo, diminuindo também o escoamento superficial. No entanto, o solo Argissolo Vermelho Amarelo, menos resistente á erosão e menos tolerante a perda de solo (Quadro 11), demanda mais atenção e cuidados.

Aquelas áreas que ficam sem proteção da vegetação durante as chuvas mais intensas deverão ser manejadas com práticas conservacionistas que impeçam os processos severos de erosão. Essas práticas conservacionistas podem ser de caráter vegetativo, edáfico ou mecânico e devem ser usadas simultaneamente para aumentar a resistência do solo ou diminuir as forças dos elementos causadores dos processos erosivos. As práticas vegetativas são as que utilizam as plantas ou resíduos vegetais para proteção do solo, como, por exemplo, cultura em faixas, plantas de cobertura, cordões de vegetação permanente, alternância de capinas, controle de ervas invasoras com roçadeiras em culturas perenes, cobertura morta, faixas de bordadura e quebra ventos. As de caráter edáfico são aquelas que se relacionam a fertilidade do solo, como o controle do fogo, a adubação verde, a adubação orgânica ou química e também a calagem. Por último, as práticas mecânicas de controle de erosão como o terraceamento, distribuição racional dos caminhos e o plantio em nível (Bertoni \& Lombardi Neto,1990).

Entretanto, segundo esses mesmos autores, a densidade da cobertura vegetal é o princípio fundamental de proteção do solo. Assim, apresentam dados sobre o efeito do tipo de uso do solo sobre as perdas por erosão, obtidos através de médias ponderadas para três tipos de solo do Estado de São Paulo. Para matas, pastagens e cafezal as perdas 
médias de solo arrastadas foram, respectivamente, 0,004 e 0,4 e 0,9 Mg.ha"-1 , e as perdas médias de água , 0,7, 0,7 e 1,1 \% da chuva caída anualmente. Em outro experimento, o efeito da cana de açúcar e do milho sobre as perdas por erosão, em declive entre 8,5 e 12,8 \% e $1.300 \mathrm{~mm}$ de chuva, foi de 12,4 e 12,0 t.ha $^{-1}$ respectivamente.

Segundo Ehlers (1999) o Instituto Agronômico de Campinas informou que o Brasil perde 25 toneladas de solo por ano por hectare cultivado, enquanto os valores

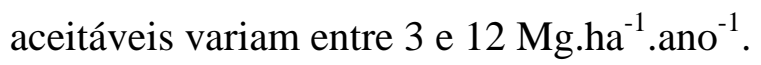

É bom lembrar que o cultivo intensivo do solo pode acarretar perda de matéria orgânica e conseqüentemente redução da fertilidade do solo e degradação de sua estrutura, compactação e erosão.Embora os fertilizantes possam repor temporariamente os nutrientes perdidos, eles não podem reconstruir a fertilidade e restaurar a saúde do solo (Gliessman, 2001).

Os quadros 10, 11 e 12 mostram as unidades de mapeamento dos solos com seus respectivos valores de erodibilidade, de tolorância de perdas e as classes de erodibilidade:

\begin{tabular}{|c|c|}
\hline Solos & $\begin{array}{c}\text { Erodibilidade } \\
\text { Mg.h.M. } \mathbf{H}^{\mathbf{1}} \mathbf{. m m}^{\mathbf{1}}\end{array}$ \\
\hline LRe+LRd & 0.0110 \\
\hline LV2 & 0.0132 \\
\hline PV3 & 0.0359 \\
\hline NVef & 0.0184 \\
\hline GH & 0.0586 \\
\hline
\end{tabular}

${ }^{1}$ Comunicação pessoal.

Quadro 10 - Tipos e associações de solos da Microbacia do Ribeirão São João e seus valores correspondentes de erodibilidade, segundo Lombardi Neto ${ }^{1}$ 


\begin{tabular}{|c|c|c|}
\hline Unidade de solo & Erodibilidade & Tolerância \\
\hline & Mg.h.M. $\mathbf{M J}^{-\mathbf{1}} \mathbf{m m}^{\mathbf{- 1}}$ & Mg.ha $^{\mathbf{1}}$ \\
\hline LRe & 0.0098 & 13.0 \\
\hline LRd & 0.0128 & 13.0 \\
\hline LV2 & 0.0132 & 14.2 \\
\hline NVef & 0.0184 & 13,4 \\
\hline PV3 & 0.0359 & 8.6 \\
\hline GH & 0.0586 & - \\
\hline
\end{tabular}

${ }^{1}$ Comunicação pessoal.

Quadro 11- Erodibilidade dos tipos de solo da microbacia hidrográfica do Ribeirão São João e a respectiva tolerância de perda de solo, segundo Lombardi Neto ${ }^{1}$

\begin{tabular}{|c|c|c|c|}
\hline Classes & Valores & \multicolumn{2}{|c|}{ Área } \\
\hline & Mg.h.MJ $\mathbf{. m m}^{-\mathbf{1}}$ & ha & \% \\
\hline muito baixa & $<0,010$ & - & - \\
\hline baixa & $0,010-0,020$ & $3.012,5$ & 82,4 \\
\hline moderada & $0,020-0,030$ & & 15,6 \\
\hline alta & $0,030-0,040$ & 570,4 & 2,0 \\
\hline muito alta & $>0,040$ & 73,1 & $\mathbf{1 0 0}$ \\
\hline Total & & $\mathbf{3 . 6 5 6}$ & \\
\hline
\end{tabular}

Quadro 12 - Distribuição das classes de erodibilidade da microbacia do Ribeirão São João 


\subsubsection{Classes de declividade}

A Microbacia do Ribeirão São João possui 77,6 \% de sua área com declividade menor do que 9\%, o que indica bom potencial para uso de mecanização; entretanto alternativas como o cultivo mínimo na cana de açúcar e o manejo racional das pastagens diminuiriam ainda mais as possibilidades de desencadeamento dos processos de erosão.

As áreas com maior declividade (9 a 18 \%) estão próximas aos cursos d’ água, principalmente do Córrego do Borralho, o que implica em adequação das práticas de manejo pelos produtores rurais para tal situação, como por exemplo, boa cobertura do solo durante todo o ano, terraceamento, adubação orgânica e outras práticas conservacionistas.

A Figura 12 apresenta a distribuição das classes de declive que ocorrem na microbacia e que estão quantificadas no Quadro 13.

\begin{tabular}{|c|c|c|}
\hline $\begin{array}{c}\text { Classes de declividade } \\
\text { (\%) }\end{array}$ & ha & Área \\
\hline$<3$ & 665,4 & 18,2 \\
\hline 3 a 6 & $1.272,3$ & 34,8 \\
\hline 6 a 9 & 899,4 & 24,6 \\
\hline 9 a 12 & 402,2 & 11,0 \\
\hline 12 a 18 & 321,7 & 8,8 \\
\hline$>18$ & 95,1 & 2,6 \\
\hline Total & $3.656,0$ & $\mathbf{1 0 0}$ \\
\hline
\end{tabular}

Quadro 13 - Distribuição das classes de declive das terras da microbacia do Ribeirão São João 


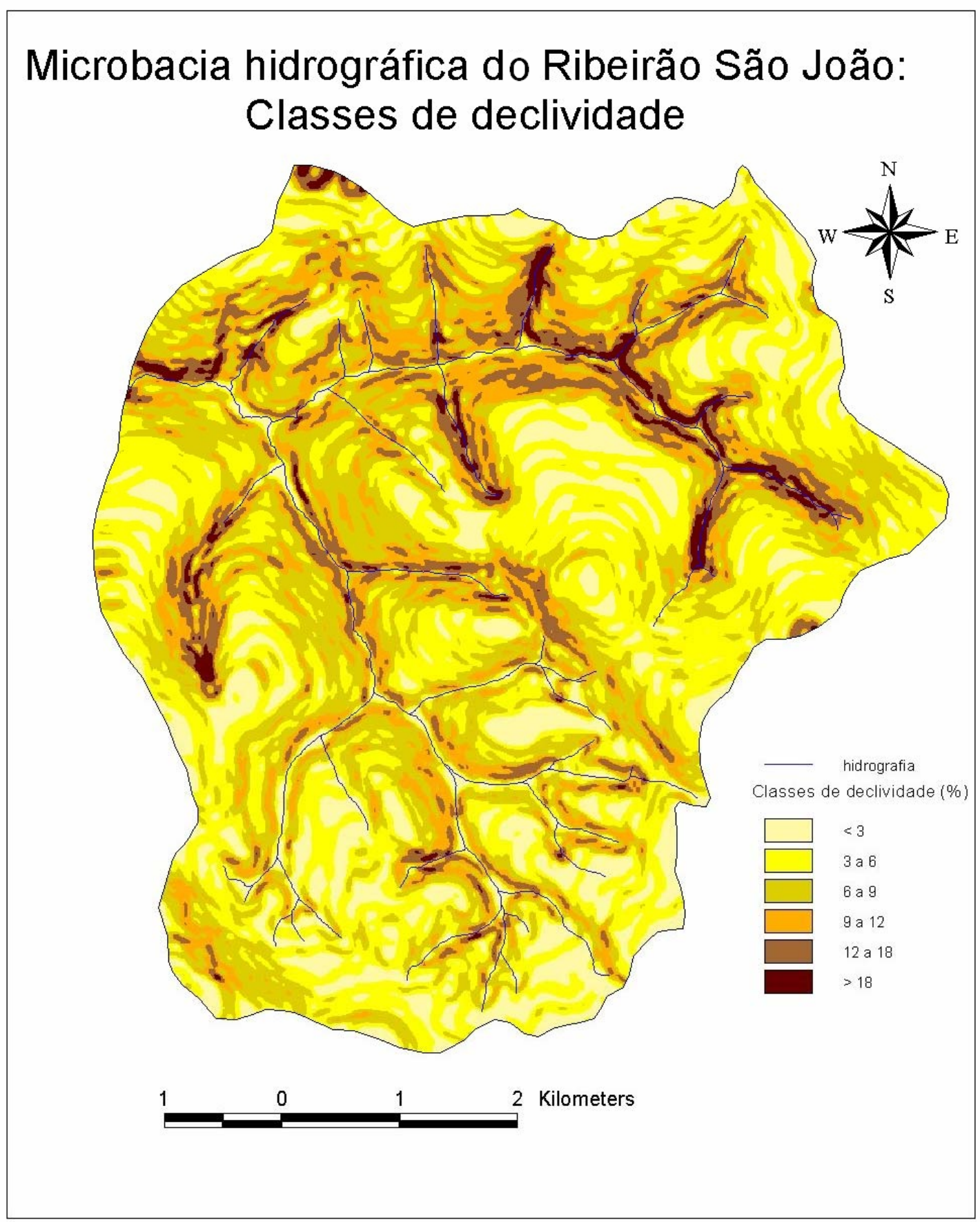

Figura 12 - Classes de Declividade da microbacia do Ribeirão São João (Mineiros do Tietê, SP). Ano: 2004 


\subsubsection{Uso e ocupação do solo}

O município de Mineiros do Tietê, com área de 19.800 ha e população de 11.603 pessoas, sendo 519 moradores da zona rural, localiza-se em região canavieira no centro do Estado de São Paulo.

A Microbacia Hidrográfica do Ribeirão São João possui 57,9 \% de sua área ocupados com a cultura da cana de açúcar e 21,6 \% com pastagem.

Os fragmentos de vegetação nativa remanescentes estão presentes em 8,7 \% da área da microbacia e as áreas em regeneração natural em 0,3 \%. Estes dados serão melhor discutidos adiante, ao serem relacionados às exigências da legislação ambiental brasileira (Áreas de Preservação Permanente e Reserva Legal) e à preservação do ecossistema ripário.

O reflorestamento, feito com eucalipto, aparece em pequena porção na microbacia (5,3\%), o que ocorre também com as culturas perenes (2,4\%), representadas principalmente pelo café e citrus, e com as culturas anuais (0,7 \%), como o milho, o arroz e o feijão.

Segundo os depoimentos dos produtores rurais da microbacia do Ribeirão São João, durante as reuniões para o diagnóstico e planejamento participativos, a cana de açúcar começou a ser introduzida na região a partir da década de 40 , simultaneamente à instalação das primeiras usinas de açúcar. Nesta época, a cultura do café ainda dominava as áreas agrícolas no centro oeste paulista, mas a partir das décadas de 1970 e 1980, com o lançamento do ProÁlcool (1975), começou a ceder espaço à cana de açúcar e à uma infraestrutura agrícola e industrial voltada à atividade sucroalcooleira.

A predominância da cana na região é uma conseqüência de fortes e persistentes fatores econômicos, como estes anteriormente citados, o que influencia os planos de manejo integrado das microbacias da região onde a monocultura canavieira está instalada.

O Quadro 14 mostra o uso e ocupação da terra na microbacia cuja distribuição espacial pode ser observada na Figura 13. 


\begin{tabular}{c|c|c|}
\hline Uso da terra & Área (ha) & Área (\%) \\
\hline Cana de açúcar & $2.116,8$ & 57,9 \\
\hline Pastagem & 789,7 & 21,6 \\
\hline Vegetação nativa & 318,1 & 8,7 \\
\hline Reflorestamento (eucalipto) & 193,8 & 5,3 \\
\hline Área urbana & 102,4 & 2,8 \\
\hline Cultura perene & 87,7 & 2,4 \\
\hline Cultura anual & 25,6 & 0,7 \\
\hline Área em regeneração natural & 11,0 & 0,3 \\
\hline Represas & 7,3 & 0,2 \\
\hline Olericultura & 3,6 & 0,1 \\
\hline Total & $\mathbf{3 . 6 5 6 , 0}$ & $\mathbf{1 0 0}$ \\
\hline
\end{tabular}

Quadro 14 - Uso e ocupação do solo na microbacia do Ribeirão São João 


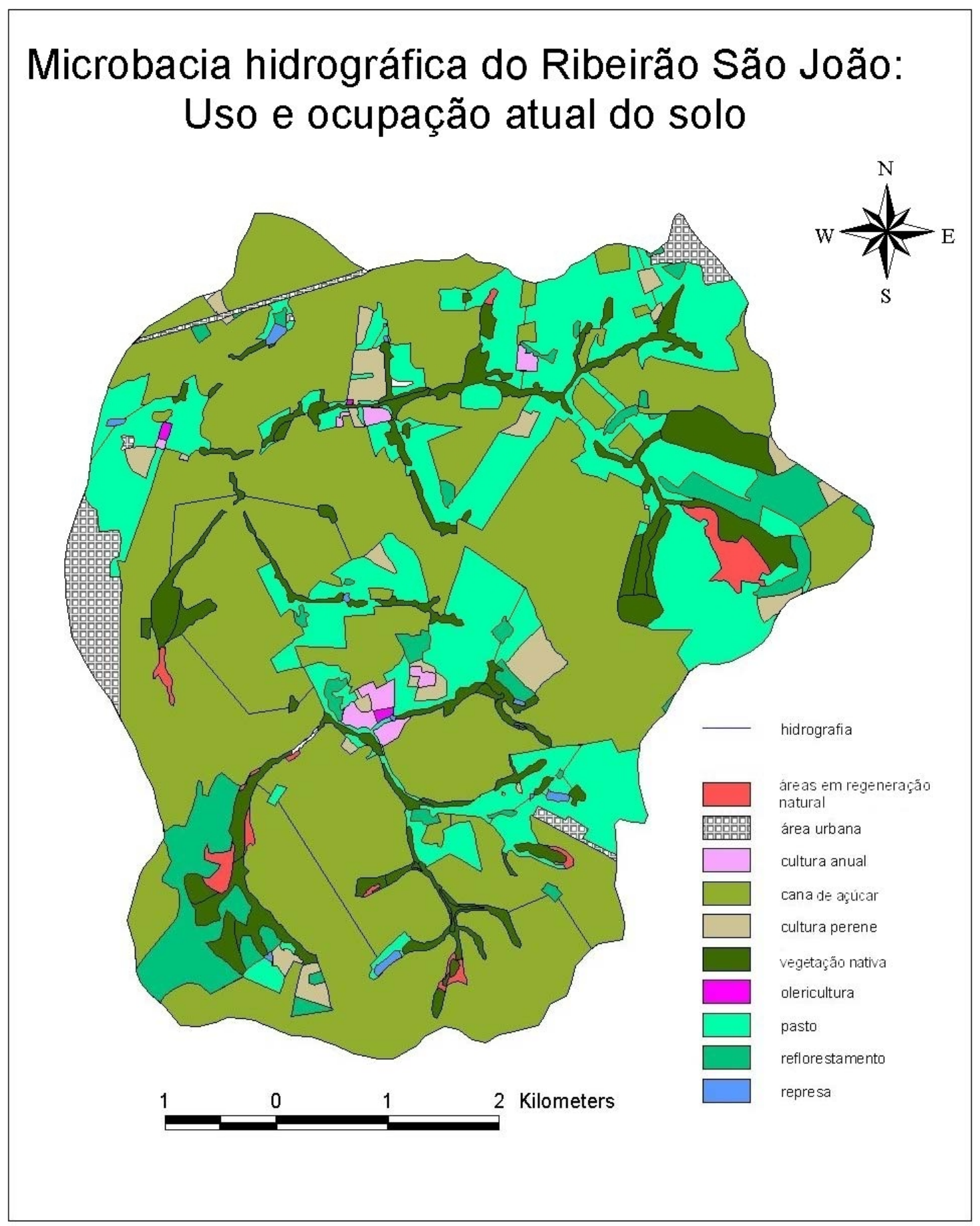

Figura 13 - Uso e ocupação atual do solo na microbacia do Ribeirão São João (Mineiros do Tietê, SP). Ano: 2000 


\subsubsection{Vegetação e Áreas de Preservação Permanente}

O manejo integrado de microbacias hidrográficas, tendo a água como enfoque central, implica numa abordagem ecossistêmica de manejo. Neste contexto a recuperação das vegetações ciliares, intimamente ligada aos valores hidrológicos e ecológicos da microbacia, assume papel fundamental.

A microbacia do Ribeirão São João, segundo o levantamento dos tipos vegetacionais e a delimitação das Áreas de Preservação Permanente, possui 372,9 ha de APP, seus trechos a serem restaurados, isto é, ocupadas com agricultura ou outros usos, correspondem a 5,3 \% da área da microbacia (193,7 ha) e 51,9 \% da própria Área de Preservação Permanente. A vegetação nativa que ocupa estas áreas, como exigido por lei, atualmente corresponde à 4,9 \% (179,2 ha) da microbacia e 48,1 \% da APP.

É possível também identificar algumas áreas mais favoráveis à localização das Reservas legais, tanto em macroescala, isto é, considerando a microbacia, quanto em microescala, tendo em vista a propriedade rural. Não somente aquelas áreas de remanescentes florestais fora de Áreas de Preservação Permanente, isto é 3,8 \% da área total correspondendo a 138,9 ha, representam a possibilidade de localização das Reservas Legais, mas também aquelas que, mesmo tendo outros usos, possuem características e potencialidades ambientais importantes, como será discutido a seguir.

A partir do levantamento dos tipos vegetacionais (Figura 14), que relacionou o estado de degradação, a localização dos fragmentos e o grau de isolamento, é possível observar que, em fragmentos florestais isolados em Áreas de Preservação Permanente o que predomina, como mostra o Quadro 15,, são as Florestas Paludosas degradadas (57,2 \%) e os Campos Úmidos Antrópicos (31,6 \%), tipos vegetacionais típicos de terrenos permanentemente encharcados. O mesmo ocorre em fragmentos não isolados em Áreas de Preservação Permanente, onde predomina as florestas ribeirinhas muito degradadas $(65,8 \%)$ as florestas paludosas degradadas $(12,4 \%)$ e as florestas ribeirinhas degradadas $(11,4 \%)$.

Os tipos vegetacionais com influência hídrica temporária ou permanente, isto é os campos úmidos, as florestas paludosas e as florestas ribeirinhas, constituem 67,3 \% 
de toda a área de vegetação nativa e 5,87 \% da área da microbacia, o que pode indicar um elevado potencial hídrico da microbacia do Ribeirão São João.

Em fragmentos fora de Área de Preservação Permanente, não isolados, prevalecem as florestas ribeirinhas muito degradadas (41,5 \%), as savanas florestadas (Cerradão) degradadas (35,0 \%) e muito degradadas (29,0 \%).

É fundamental a manutenção dos fragmentos de Cerradão, que ocupam 1,92 \% da área da microbacia e 22,7 \% da vegetação nativa presente, pois desempenham um papel ambiental importante, no que diz respeito á preservação de espécies florestais típicas deste tipo vegetacional muito degradado em todo o Estado de São Paulo e da fauna local. Estes fragmentos podem ser protegidos se considerados reservas legais, sob a ótica da microbacia ou das propriedades rurais.

O estabelecimento das relações do estado de degradação, da legislação ambiental e do grau de isolamento dos tipos vegetacionais, foi considerado para melhor caracterizar a vegetação da microbacia e para respaldar futuras intervenções de restauração das Áreas de Preservação Permanente e Reservas Legais. 


\begin{tabular}{|c|c|c|c|c|c|c|}
\hline \multirow{2}{*}{ Tipo vegetacional } & \multirow{2}{*}{$\begin{array}{c}\text { Localização } \\
\text { dos fragm. } \\
\text { com relação à } \\
\text { APP }\end{array}$} & \multirow{2}{*}{$\begin{array}{c}\text { Isolam. } \\
\text { dos } \\
\text { fragm. }\end{array}$} & \multicolumn{2}{|c|}{ Área } & \multirow{2}{*}{$\begin{array}{c}\begin{array}{c}\text { Área da } \\
\text { vegetação } \\
\text { Natural }\end{array} \\
(\%)\end{array}$} & \multirow{2}{*}{$\begin{array}{r}\begin{array}{r}\text { Área da } \\
\text { microb }\end{array} \\
(\%)\end{array}$} \\
\hline & & & (ha) & $(\%)$ & & \\
\hline Campos Úmidos antrópicos & \multirow{16}{*}{ Dentro de APP } & \multirow{5}{*}{ isolado } & 22,0 & 31,6 & 6,9 & 0,60 \\
\hline Floresta Paludosa degradada & & & 39,8 & 57,2 & 12,5 & 1,08 \\
\hline Floresta Paludosa muito degradada & & & 7,0 & 10,2 & 2,2 & 0,20 \\
\hline Floresta Paludosa pouco degradada & & & 0,7 & 1,0 & 0,2 & 0,02 \\
\hline subtotal & & & 69,5 & 100 & 21,8 & 1,90 \\
\hline Campos Úmidos antrópicos & & \multirow{11}{*}{$\begin{array}{c}\text { não } \\
\text { isolado }\end{array}$} & 3,3 & 3,0 & 1,0 & 0,10 \\
\hline Floresta Paludosa degradada & & & 12,4 & 11,3 & 3,9 & 0,34 \\
\hline Floresta Paludosa muito degradada & & & 1,9 & 1,7 & 0,6 & 0,05 \\
\hline Floresta Paludosa pouco degradada & & & 0,3 & 0,3 & 0,1 & 0,01 \\
\hline Savana florestada degradada & & & 5,6 & 5,1 & 1,8 & 0,15 \\
\hline Savana florestada muito degradada & & & 2,5 & 2,3 & 0,8 & 0,01 \\
\hline $\begin{array}{l}\text { Floresta Estacional Semidecidual } \\
\text { degradada }\end{array}$ & & & 5,7 & 5,2 & 1,8 & 0,15 \\
\hline $\begin{array}{l}\text { Floresta Estacional Semidecidual muito } \\
\text { degradada }\end{array}$ & & & 0,8 & 0,7 & 0,2 & 0,02 \\
\hline Floresta Ribeirinha degradada & & & 11,4 & 10,4 & 3,6 & 0,31 \\
\hline Floresta Ribeirinha muito degradada & & & 65,8 & 60,0 & 20,7 & 1,80 \\
\hline subtotal & & & 109,7 & 100 & 34,5 & 3,00 \\
\hline Savana florestada degradada & \multirow{7}{*}{ Fora de APP } & \multirow{7}{*}{$\begin{array}{c}\text { não } \\
\text { isolado }\end{array}$} & 35,0 & 25,2 & 11,0 & 0,96 \\
\hline Savana florestada muito degradada & & & 29,0 & 20,9 & 9,1 & 0,80 \\
\hline $\begin{array}{l}\text { Floresta Estacional Semidecidual } \\
\text { degradada }\end{array}$ & & & 17,4 & 12,5 & 5,5 & 0,47 \\
\hline $\begin{array}{l}\text { Floresta Estacional Semidecidual muito } \\
\text { degradada }\end{array}$ & & & 7,9 & 5,7 & 2,5 & 0,21 \\
\hline Floresta Ribeirinha degradada & & & 8,1 & 5,8 & 2,6 & 0,22 \\
\hline Floresta Ribeirinha muito degradada & & & 41,5 & 29,9 & 13,0 & 1,14 \\
\hline subtotal & & & 138,9 & 100 & 43,7 & 3,80 \\
\hline Total & & & 318,1 & 100 & 100 & 8,70 \\
\hline
\end{tabular}

Quadro 15 - Nível de degradação dos tipos vegetacionais encontrados na Microbacia do

Ribeirão São João (Mineiros do Tietê, SP), localização dos seus fragmentos florestais com relação à Áreas de Preservação Permanente (APP), isolamento destes fragmentos com relação à outros e área de cada fragmento em hectares (ha) e em porcentagem (\%), porcentagem de cada fragmento com relação à área total de vegetação nativa e à área da microbacia 


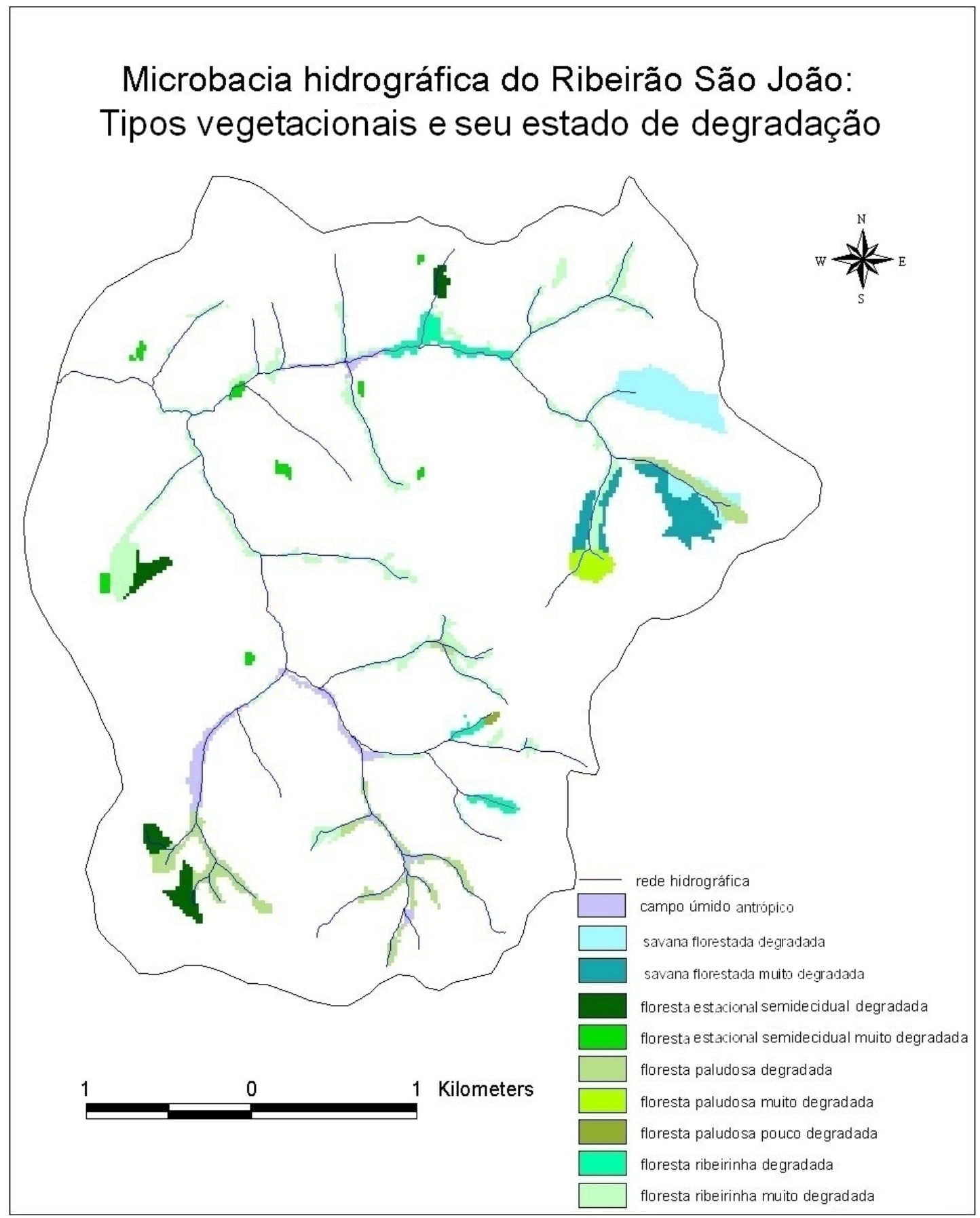

Figura 14 - Tipos vegetacionais dos fragmentos de vegetação nativa remanescentes da Microbacia do Ribeirão São João (Mineiros do Tietê, SP) e seu estado de degradação. Ano: 2004 
Os tipos vegetacionais encontrados na microbacia do Ribeirão São João podem ser descritos com base no trabalho de Rodrigues (1999) desenvolvido na região de Piracicaba. São eles:

Floresta Estacional Semidecidual: esta formação é caracterizada por apresentar um dossel irregular, entre 15 e $20 \mathrm{~m}$ de altura, com presença de algumas árvores emergentes de até 25 à 30 m de altura, sendo observada a deciduidade em algumas espécies típicas desta formação, na estação sêca. Este tipo florestal pode ocupar as mais variadas condições edáficas, aparecendo tanto em solos argilosos como em arenosos.

Muitas espécies que ainda podem ser encontradas no dossel dos fragmentos de florestas da microbacia do Ribeirão São João são afetadas pelo extrativismo seletivo, como por exemplo a peroba (Aspidosperma polyneuron Muell. Arg.), o guatambu (A. ramiflorum Muell. Agr.), o cedro (Cedrela fissilis Vell.), o pau marfim (Balfourodendron riedellianum Engl.), o jatobá (Hymenaea courbaril L.), o guarantã (Esenbeckia leiocarpa Engl.), a copaíba (Copaifera langsdorffii Desf.), etc.

Outras comuns nesta formação, em fragmentos menos degradados pela ação antrópica são: o araribá (Centrolobium tomentosum Benth.), a paineira (Chorisia speciosa St. Hil.), a mamica de porca (Zanthoxyllum spp.), a embira de sapo (Lonchocarpus spp.), o guaritá (Astronium graveolens Jacq.), etc. No sub-dossel e subbosque podem ocorrer o catiguá (Trichilia spp.), camboatã (Cupania vernalis Camb. e Matayba elaeagnoides Radlk.), sete capotes (Campomanesia spp.), chupa ferro (Metrodorea nigra St. Hil.), etc.

Os fragmentos florestais muito degradados da microbacia são caracterizados pela predominância de espécies dos estágios iniciais da sucessão como a crindiúva (Trema micrantha (L.) Blume), capixingui (Croton floribundus Spreng.), guaçatonga (Casearia sylvestris Sw.), embaúba (Cecropia spp.), açoita cavalo (Luehea divaricata Mart.), entre outras e alguns indivíduos dos estágios finais da sucessão.

Estas áreas degradadas apresentam ausência de dossel definido, grande abundância de lianas sobre os indivíduos remanescentes e por isso ocorrência de indivíduos mortos em pé. 
Floresta Estacional Semidecidual Ribeirinha: esta formação se apresenta ao longo dos cursos d’ água em duas situações distintas, ou sofre as interferências diretas da presença da água em algum período do ano, tanto na forma de enchentes como pela elevação do lençol freático ou não está sujeita às interferências causadas pela água. Na primeira condição, possui características florísticas e estruturais próprias, devido a uma seletividade das espécies, relacionada a adaptabilidade fisiológica de maneira a resistir a saturação hídrica do solo, mesmo por períodos curtos de tempo, sendo as espécies típicas destes locais as figueiras (Ficus spp.), o guanandi (Calophyllum brasiliensis Camb.),o ingá (Inga affinis DC. Hook et Arn.), o genipapo (Genipa americana L.), a pinha do brjo (Talauma ovata St. Hil.), etc.

Estas espécies são comumente encontradas nas florestas ribeirinhas da microbacia do Ribeirão São João.

Na condição onde a dinâmica é determinada por outros fatores que não a presença de água no solo a proporção de espécies típicas da floresta estacional semidecidual é maior.

Floresta Paludosa: são também chamadas de florestas de várzeas, florestas de brejo, florestas higrófilas em função de sua característica principal e seletiva de permanente encharcamento do solo, por isso apresentam características florísticas e estruturais próprias, que são distintas das florestas sobre a zona ciliar, em áreas com permanência temporária da água. Possuem distribuição naturalmente fragmentada, pois ocorrem apenas em solos com forte influência hídrica. Têm uma diversidade menor que as demais formações florestais do Estado de São Paulo, em função da presença quase permanente da água, agindo como fator limitante para a ocorrência das espécies.

As espécies mais comuns nestas formações, encontradas também nas áreas paludosas da microbacia, são: o guanandi (Calophyllum brasiliense Camb.), o almiscar (Protium almecega March.), a pinha do brejo (Talauma ovata St. Hil.), o marinheiro (Guarea kunthiana Adr. Juss.), a embaúba (Cecropia pachystachya Trécul), o pau de viola (Citharexylum myrianthum Cham.), a figueira (Ficus spp), maria mole (Dendropanax cuneatum Decne et Planch), etc. No sub-bosque, como espécie indicadora temos a palmeira Geonoma brevispatha Barb.Rodr., e nas bordas um arbusto muito 
comum é a Miconia chamissois Naud. Algumas espécies podem ocorrer tanto em matas de brejo quanto em florestas ribeirinhas, como a peroba d' água (Sessea brasiliensis Tol.).

Os campos úmidos antrópicos ou várzeas possuem fisionomia com predominância de vegetação herbácea, situando-se em áreas que provavelmente eram ocupadas originalmente por florestas paludosas. Estes campos se desenvolvem em locais hoje permanentemente encharcados, uma situação, em geral, determinada pela ação antrópica.

Savana Florestada ou Cerradão: o Cerradão apresenta algumas características semelhantes á Floresta Estacional Semidecidual devido ás condições ambientais coincidentes, como a fisionomia florestal, maior disponibilidde hídrica em relação ao cerrado “sensu stricto”, a ciclagem de nutrientes e restrição luminosa no sub-bosque, além de muitas espécies em comum, diferindo pela condição edáfica e de retenção de água no solo.

As espécies mais comuns encontradas nos fragmentos de cerradão da microbacia são: peito-de-pombo (Tapirira Guianensis Aubl.), óleo de copaiba (Copaifera langsdorfii Desf.), amendoim (Platypodium elegans Vog.), faveiro (Pterodon pubescens Benth.), canela (Ocotea spp.), pau de tucano (Vochysia tucanorum (Spreng.) Mart.), mamica de porca (Zanthoxylum spp.), angico (Anadenanthera falcata (Benth.)Spreng. e Anadenathera spp.), orelha de negro ou tamboril (Enterolobium gummiferum (Mart.) Macbr.), etc. 


\subsubsection{Estrutura Fundiária}

Na Microbacia Hidrográfica do Ribeirão São João existe 111 propriedades rurais, sendo que 82,9 \% delas possuem áreas menores de 50 hectares (Quadro 1). A elaboração desta carta (Figura 15) contou com a participação dos produtores rurais, principalmente os que estão há mais tempo no local e portanto conhecem melhor a microbacia e os limites das propriedades rurais.

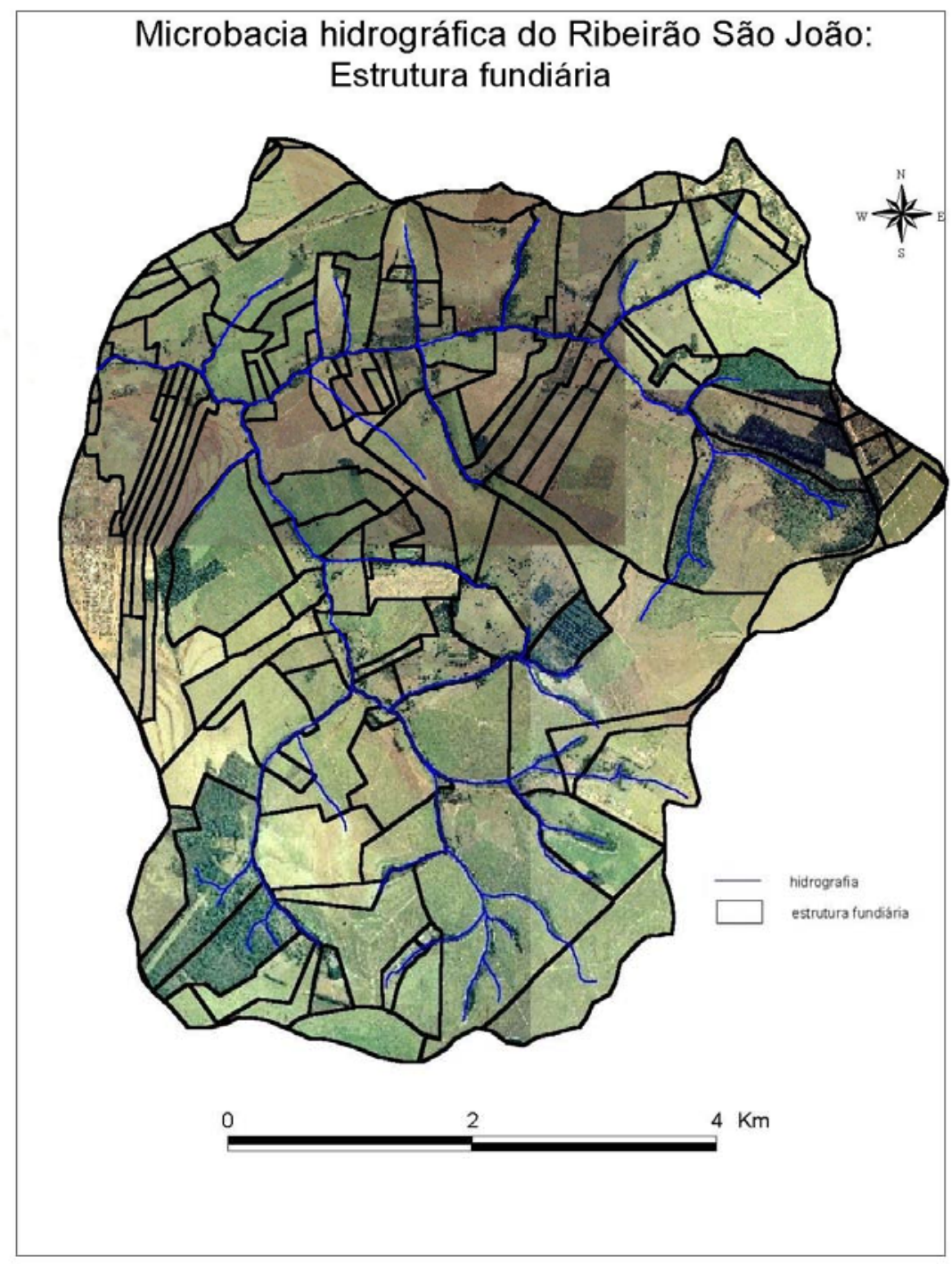

Figura 15 - Estrutura fundiária da microbacia do Ribeirão São João (Mineiros do Tietê, SP). Ano: 2002 


\subsubsection{Diagnóstico e planejamento participativos}

É importante em um plano de manejo integrado de microbacias, elaborado ou não com a inclusão do conceito de zona ripária, assegurar a participação pública tanto nos processos de análise quanto nos de tomada de decisões.

$\mathrm{Na}$ composição dos cenários alternativos (com inclusão da zona ripária) o envolvimento da comunidade é especialmente relevante para que esta nova proposta seja entendida, discutida e inserida no diagnóstico e no planejamento integrado da microbacia.

Segundo Montgomery et al. (1995) o sucesso da implementação do manejo em microbacias para a preservação da integridade do ecossistema requer conhecer e considerar não somente os aspectos físicos e biológicos, mas também o contexto social no qual as decisões serão tomadas, considerando além do nível local, o regional e o global.

A verdadeira visão interdisciplinar deve integrar o conhecimento empírico da comunidade rural com o conhecimento científico, num processo contínuo, é o que destaca Czajkowski (2004).

Gliessman (2001) afirma que os sistemas agrícolas desenvolvem-se como o resultado da co-evolução que ocorre entre a cultura e o ambiente, e uma agricultura sustentável valoriza o componente humano, assim como o ecológico, e as relações que ocorrem entre ambos. Portanto é necessário entender os agroecossistemas como sistemas socioecológicos considerando a importância do elemento humano para a produção e para o estabelecimento do manejo sustentável.

A tendência em buscar o envolvimento na comunidade no planejamento de áreas de seu interesse é recente e possibilita legitimar as ações e obter a cumplicidade dos produtores rurais e sua família na aplicação das metas decididas em conjunto.

O trabalho em microbacias favorece a organização e participação de produtores rurais. As contribuições da comunidade local podem ser inseridas aos interesses e questões regionais. 
Na microbacia do Ribeirão São João foram realizadas as primeiras reuniões e atividades relacionadas ao estímulo da participação da comunidade nas tomadas de decisão para o planejamento socioeconômico e ambiental, num ambiente em que este tipo de prática não é comum. Portanto muitos fatores podem ter influenciado, neste primeiro momento, a participação significativa e efetiva da comunidade e a aplicação dos princípios participativos, tais como, insegurança, falta de maturidade para o envolvimento neste tipo de processo, pré-entendimento não consolidado dos objetivos, etc.

Na verdade este é um processo de implementação a médio e longo prazos, onde a maturidade e a participação mais consistente serão alcançadas com o tempo, com a evolução do processo através de práticas que estimulem a participação interativa.

O diagnóstico e o planejamento participativos da Microbacia Hidrográfica do Ribeirão São João derivados da participação e envolvimento dos beneficiários, isto é, os produtores rurais e suas famílias, mesmo sem a apresentação do conceito de zona ripária, resultaram na seguinte priorização das ações a serem implementadas para a busca da sustentabilidade social, econômica e ambiental na microbacia:

1. criação de uma associação de produtores rurais, pois assim, coletivamente, segundo a comunidade, ficaria mais fácil alcançar os outros objetivos;

2. proteção dos cursos d' água através do plantio de mata ciliar, para evitar o assoreamento e poluição dos rios e nascentes;

3. proteção das matas ciliares, principalmente contra o fogo, durante a colheita da cana de açúcar, e outros fatores de impacto;

4. conservação do solo através de terraceamento e outras práticas recomendadas para cada situação;

5. adequação das estradas rurais;

6. incremento da patrulha agrícola, que serve os pequenos e médios produtores rurais, mediante o pagamento de baixas taxas, com serviços de preparo do solo;

7. construção de abastecedouros de água comunitários para propriedades que não possuem acesso fácil á água; 
8. incentivo à diversidade de culturas na microbacia, através de cursos, palestras e excursões;

9. planejamento para a implementação de uma agroindústria que possa respaldar a diversificação de culturas e agregar valor aos produtos.

Esses foram os anseios da comunidade expostos em reunião para o planejamento participativo da Microbacia Hidrográfica do Ribeirão São João, o que pode denunciar uma tendência para o despertar de uma visão coletivista e, principalmente para uma percepção ambiental dos produtores referente à proteção dos rios pela mata ciliar, assim com uma preocupação com a qualidade e quantidade de água. Por outro lado, estas perspectivas dos produtores rurais devem também, ou apenas, estar fortemente relacionados a uma pressão imposta pela legislação ambiental para a proteção das Áreas de Preservação Permanente e aos incentivos previstos no Programa Estadual de Microbacias Hidrográficas, como por exemplo, a doação de mudas para o plantio das matas ciliares e apoio, através de parcial amparo financeiro, às práticas de conservação do solo e à formação de associações.

As decisões referentes à proteção dos recursos naturais são afetadas por certas características de comportamento dos produtores rurais, como, por exemplo: a-) formam um grupo heterogêneo no que diz respeito ao acesso a informações, disponibilidade de recursos, etc; b- suas decisões são tomadas com objetivos a curto prazo, o que desencoraja investimentos em proteção ambiental; c-) os fatores econômicos definem o que é economicamente possível, mas os fatores culturais, pessoais e ambientais não devem ser esquecidos; d-) a adoção de mudanças em suas ações é lenta ( por exemplo o milho híbrido levou cerca de 9 anos para ser adotado nos EUA) e subestimam a severidade dos problemas ambientais em sua propriedade (OTA, 1990). Isso tudo deve ser considerado em planos que visem preservar ou recuperar os recursos naturais.

Azevedo (2000), após uma revisão bibliográfica para investigar os fatores que prevalecem nas decisões dos produtores rurais de várias partes do mundo quanto a preservação ambiental, concluiu que há concordância, entre todos os autores estudados, quanto à preponderância do fator econômico. Isto é, as decisões pelo produtor rural, 
relacionadas a preservação de determinado ecossistema, estão baseadas no pressuposto de que preservar implica em perda econômica, decorrente da desvalorização do capital (terra), da perda de rendimentos que seriam gerados com a exploração da área e de despesas com a sua manutenção, já que os danos ambientais, advindos da não preservação, não são contabilizados.

Por outro lado, Galjart (1979) sustenta que as questões relacionadas de maneira geral ao desenvolvimento agrícola podem ser classificadas em três itens:

1. “ignorância (o agricultor não sabe fazer outras coisas além daquelas que tem feito);

2. incapacidade (o agricultor sabe o que deveria fazer, mas é incapaz de fazê-lo, quer seja por motivos financeiros ou por outras razões);

3. desinteresse (o agricultor sabe o que deveria fazer e pode fazê-lo, mas prefere seguir outros valores).”

Esta classificação pode ser relacionada, dentro do contexto da presente discussão, aos aspectos que influenciam o produtor rural quanto à preservação ambiental. A ignorância seria referente ao desconhecimento das vantagens de se preservar a natureza ou das leis ambientais; a incapacidade implicaria em se ele é capaz financeiramente ou por diversas outras razões de implementar práticas de preservação ou restauração ambientais e o desinteresse representaria sua preferência em não fazê-lo, podendo ser influenciada por questões culturais.

A ignorância e o desinteresse podem ser combatidos com a difusão do conhecimento e o envolvimento dos aspectos culturais em trabalhos de extensão rural. A incapacidade pode ser minimizada com políticas públicas adequadas, crédito agrícola, incentivos como os oferecidos pelos programas estaduais de microbacias em parceria com o Banco Mundial, estruturação da comercialização da produção familiar, etc.

Na Microbacia do Ribeirão São João, apenas uma parcela insignificante dos produtores rurais desconhecem as leis ambientais, entretanto seu conhecimento sobre os benefícios dos serviços ambientais realizados pela mata ciliar, por exemplo, é superficial. Os produtores rurais são reticentes na recuperação das matas ciliares devido á responsabilidade de acompanhamento e manutenção das mudas durante os primeiros 
anos e pelas questões econômicas envolvidas (gastos com o plantio e manutenção, perda de área de plantio, etc). Entretanto, como mostra o resultado do diagnóstico e do planejamento participativos, os produtores estão dispostos a recuperar as matas ciliares da microbacia e a proteger os seus recursos hídricos, provavelmente com a intenção de se adequarem às leis ambientais através dos incentivos (doação de mudas de espécies nativas e apoio para construção de cercas para proteção da mata ciliar, por exemplo) oferecidos pelo programa de microbacias hidrográficas do Estado de São Paulo.

Esta é, entretanto, uma afirmação calcada basicamente sobre a experiência prática de convivência no meio rural, em informações secundárias, como o Levantamento Censitário das Unidades de Produção Agropecuária (LUPA - CATI), sem confirmação de dados estáticos, necessitando, portanto, de uma sistematização mais adequada de caráter exploratório.

O levantamento socioeconômico e ambiental da microbacia do Ribeirão São João, embora realizado através de questionários aplicados aos produtores, o que nem sempre resulta em informações puramente representativas da realidade, mas que apresenta uma tendência forte em determinada direção, demonstra a percepção dos produtores rurais quanto às questões sobre água e solo. Segundo este levantamento, 54 \% dos produtores responderam que a qualidade da água não permite o seu uso, 94 \% concordam que há ocorrência de erosão em sua propriedade e entre as práticas agrícolas indicadas, 35 produtores responderam que não há proteção conservacionista em suas terras, 79 responderam que usam práticas mecânicas, 4 responderam que usam práticas vegetativas e 53 produtores possuem mata ciliar em suas propriedades (o estado de degradação destes fragmentos foi descrito anteriormente).

Essa visão dos produtores indica uma percepção da degradação dos recursos naturais nas propriedades, o que pode gerar uma preocupação com o futuro daqueles mais sensíveis às questões ambientais, principalmente no que se refere aos recursos naturais intimamente relacionados à produção agrícola.

Ferretti (2000) desenvolveu um estudo com o objetivo de analisar o Programa de Fomento Florestal do viveiro de produção de mudas da CESP de Porto Primavera, identificar o que levou os produtores fomentados pelo viveiro a participar, ou desistir, do 
Programa de Fomento Florestal da Companhia, saber como este público avalia o Programa e registrar sugestões e reivindicações dos produtores.

Este autor verificou que os resultados obtidos com sua pesquisa não confirmaram a sua hipótese de que grande parte dos produtores aderiu ao Programa principalmente pelo fato de poder receber mudas e assistência técnica gratuitas, o que considerou tratarse de um incentivo necessário, mas não suficiente. Sua conclusão final foi de que a questão legal, aliada ao temor da ação das diversas instituições ligadas ao setor de meio ambiente, foi o motivo que levou os produtores rurais, que responderam ao questionário elaborado pelo autor, a participar do fomento florestal da CESP.

Contudo, Ferretti (2000) percebeu, ao mesmo tempo, que a conservação dos recursos hídricos e do solo também têm motivado produtores rurais ao plantio de espécies florestais nativas, indicando uma preocupação por parte dos produtores com a conservação dos recursos naturais, principalmente aqueles mais ligados à produção agropecuária, de suas áreas.

As recomendações deste autor foram de que o programa da CESP deveria se ater mais às ações de divulgação, sensibilização do produtor rural, e busca de alternativas que possibilitassem a presença do elemento arbóreo na propriedade agrícola, tanto como componente econômico quanto ambiental.

As conclusões deste estudo podem ser aplicadas ao Programa Estadual de Microbacias do Estado de São Paulo, que também tem dentro de suas previsões de incentivos, a doação de mudas e o acompanhamento técnica para o plantio da mata ciliar pelos agricultores das microbacias trabalhadas.

No entanto, este programa sendo desenvolvido pela Coordenadoria de Assistência Técnica Integral (CATI), órgão responsável pela extensão rural no estado, deve ter a possibilidade, a responsabilidade, a habilidade e o treinamento necessário para desenvolver atividades extensionistas de sensibilização do produtor rural para a proteção e restauração das matas ciliares, de difusão do conhecimento legal e técnico a respeito deste assunto, de busca de alternativas de caráter econômico, cultural e ambiental que predisponha os produtores em preservar e recuperar as florestas ripárias. 
Ainda com base no trabalho de revisão, Azevedo (2000) destaca a ação do poder público no que se refere à implementação de medidas para preservação em propriedades rurais, seja por meio da elaboração e aplicação de leis restritivas, como sugerido por alguns autores, seja definindo mecanismos de subsídios, como sugerido por outros, ou promovendo programas de extensão rural, como sugerido por alguns outros autores.

No Brasil, como será discutido adiante, as questões legais pertinentes às vegetações ciliares, consideradas Áreas de Preservação Permanente, às Reservas legais e aos incentivos para reflorestamento, através de deduções fiscais, foram regulamentadas pelo Código Florestal, que foi instituído em 1965, pela lei número 4.771/65 e, no Estado de São Paulo a Resolução 47, de 26 de novembro de 2003, orienta o reflorestamento heterogêneo de áreas degradadas.

No que se refere aos programas de extensão rural, como já discutido, assim como a pesquisa científica, estiveram, até recentemente, prioritariamente preocupados em aumento da produção e do rendimento agropecuários. Entretanto, atualmente, a degradação da natureza e a poluição ambiental têm provocado um redirecionamento das demandas da atividade agrícola.

Os trabalhos de extensão rural voltados à recuperação florestal estão hoje inseridos principalmente em programas de manejo integrado de microbacias hidrográficas, desenvolvidos tanto a nível nacional como estadual, como é o caso do Programa Estadual de Microbacias Hidrográficas da Secretaria de Agricultura e Abastecimento do Estado de São Paulo. A extensão rural pode, além de orientar as atividades de recuperação florestal, promover, através da educação ambiental do homem do campo e de sua família, mudanças consistentes na maneira que eles têm de se relacionarem com a natureza.

A possibilidade de apontar as prioridades do manejo na microbacia a partir das perspectivas dos produtores rurais delineou um apoio ao desenvolvimento da aplicação do cenário alternativo, aquele que considera a priorização dos aspectos hidrológicos da microbacia. 


\subsection{Integração dos dados para a composição dos cenários convencionais (sem inclusão da zona ripária) e alternativos (com inclusão da zona ripária) e comparação dos riscos estabelecidos a partir de cada cenário}

Os cenários foram construídos para expor a proposta de inclusão do manejo hidrológico em planos de manejo integrado de microbacias hidrográficas, principalmente os desenvolvidos através de programas de órgãos públicos estaduais, com grande potencial de se difundir no espaço e se perpetuar no tempo, como é o caso dos Programas Estaduais de Microbacias Hidrográficas dos Estados.

\subsubsection{Composição dos cenários convencionais (sem inclusão da zona ripária)}

O cenário convencional descreve as análises ambientais feitas com base nas classes de capacidade de uso, que representam uma abordagem com ênfase econômica, e no potencial natural de erosão, que evidenciam uma preocupação voltada às questões ambientais. As seguintes cartas foram construídas para comporem os cenários convencionais.

- Classes de Capacidade de Uso do Solo

As classes de capacidade de uso resultaram do cruzamento dos planos de informação de solo e de declividade.

A classificação da capacidade de uso da terra é importante para identificar o grau de risco de degradação dos solos e a indicação de seu melhor uso, tanto para uma propriedade agrícola, isto é, em microescala, como para um conjunto delas, isto é, para o planejamento do manejo integrado de uma microbacia, em mesoescala (Lepsch, 2002).

As classes de Capacidade de Uso devem ser consideradas em conjunto aos aspectos sociais, econômicos e ambientais (Bertoni \& Lombardi Neto,1990).

O Quadro 16 permite observar que a microbacia tem 46,0 \% de sua área classificada como classe de capacidade de uso III, isto é, terras cultiváveis, com culturas anuais ou perenes, mas com necessidade de implementação de práticas adequadas de 
conservação. A classe IV, que apresenta sérios problemas de conservação, abrange 43,7 $\%$, concentrados nas margens da rede de drenagem.

A classe $\mathrm{V}$, terras praticamente planas, com problemas de encharcamento ou afloramento de rochas, que devem ser mantidas com pastagem ou reflorestamento, ou algumas culturas perenes, ocupam 2,1 \% da microbacia, e estão presentes unicamente no Ribeirão São João, não ocorrendo no Córrego do Borralho.

As classes VI e VII ocupam 6,0 \% da área, possuem condições restritivas ao cultivo e de grande probabilidade de ocorrer erosão. Essas áreas estão localizadas ao longo dos cursos d' água da microbacia, o que representa um grande risco ambiental relacionado á contaminação e assoreamento das águas dos rios, caso seu uso e manejo não sejam adequados. A classe II representa apenas 2,2 \% da microbacia e se localiza principalmente próxima ao Córrego do Borralho.

Na Microbacia do Ribeirão São João, as classes de capacidade de uso se distribuem conforme a Figura 16.

Diante desse cenário, a classificação da capacidade de uso da microbacia possibilita o planejamento da utilização de técnicas integradas de conservação do solo e da água, o que inclui práticas vegetativas, edáficas e mecânicas de conservação do solo em toda a sua área cultivada.

\begin{tabular}{|c|c|c|}
\hline Classes de Capacidade de Uso & Área (ha) & Área (\%) \\
\hline Classe II & 80,4 & 2,2 \\
\hline Classe III & $1.681,8$ & 46,0 \\
\hline Classe IV & $1.597,7$ & 43,7 \\
\hline Classe V & 76,8 & 2,1 \\
\hline Classe VI & 212,0 & 5,8 \\
\hline Classe VII & 7,3 & 0,2 \\
\hline Total & $\mathbf{3 . 6 5 6 , 0}$ & $\mathbf{1 0 0}$ \\
\hline
\end{tabular}

Quadro 16 - Classes de capacidade de uso da microbacia hidrográfica do Ribeirão São João e as respectivas áreas 


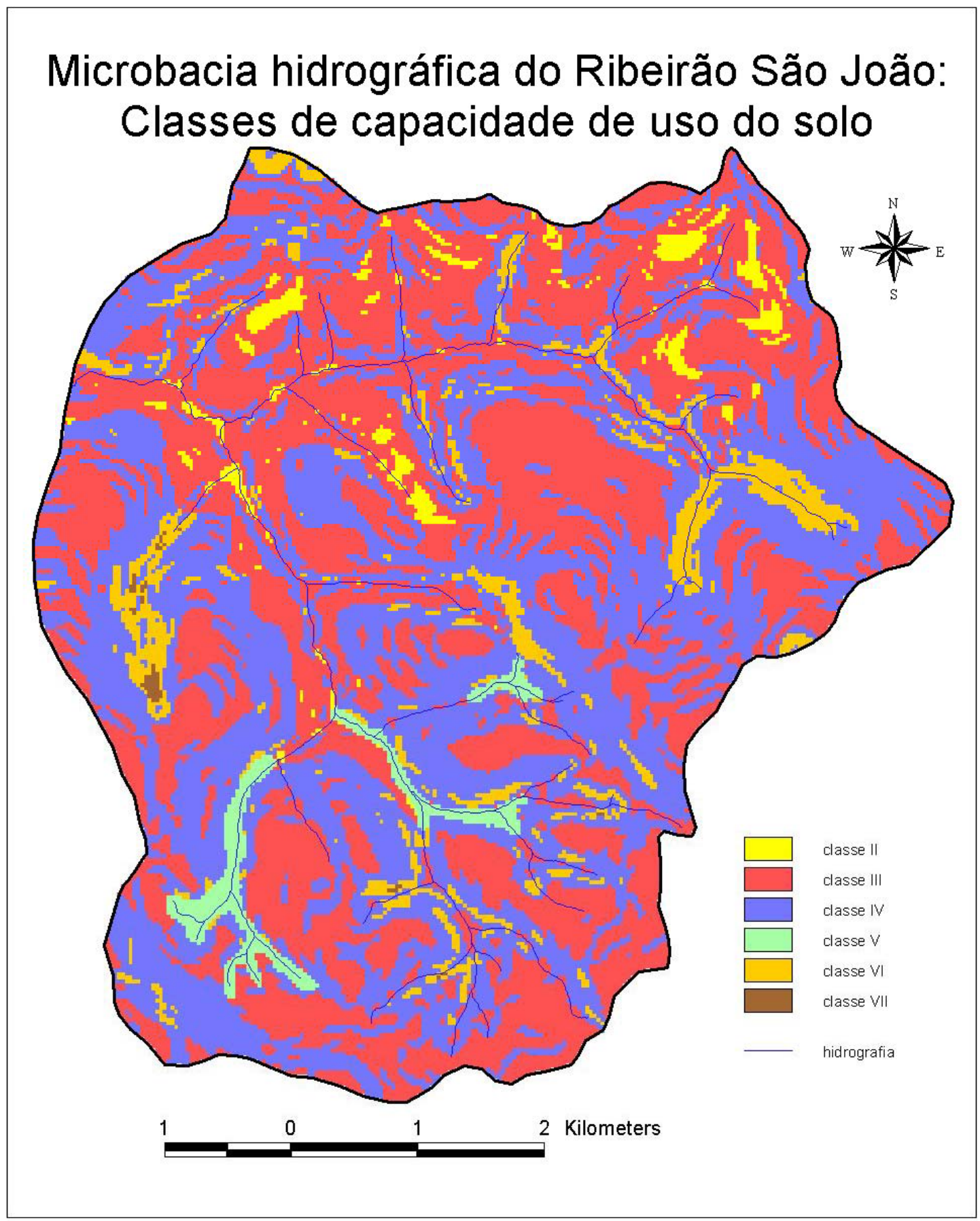

Figura 16 - Classes de capacidade de uso, segundo Lepsch et al. (1983), da microbacia do Ribeirão São João (Mineiros do Tietê, SP). Ano: 2004 


\section{- Adequação de Uso das Terras}

Para a obtenção do mapa de Adequação do Uso da Terra, foram sobrepostos os Planos de Informação de Classes de Capacidade de Uso do Solo e o de Uso Atual, cujos resultados são mostrados na Figura 17 e no Quadro 17.

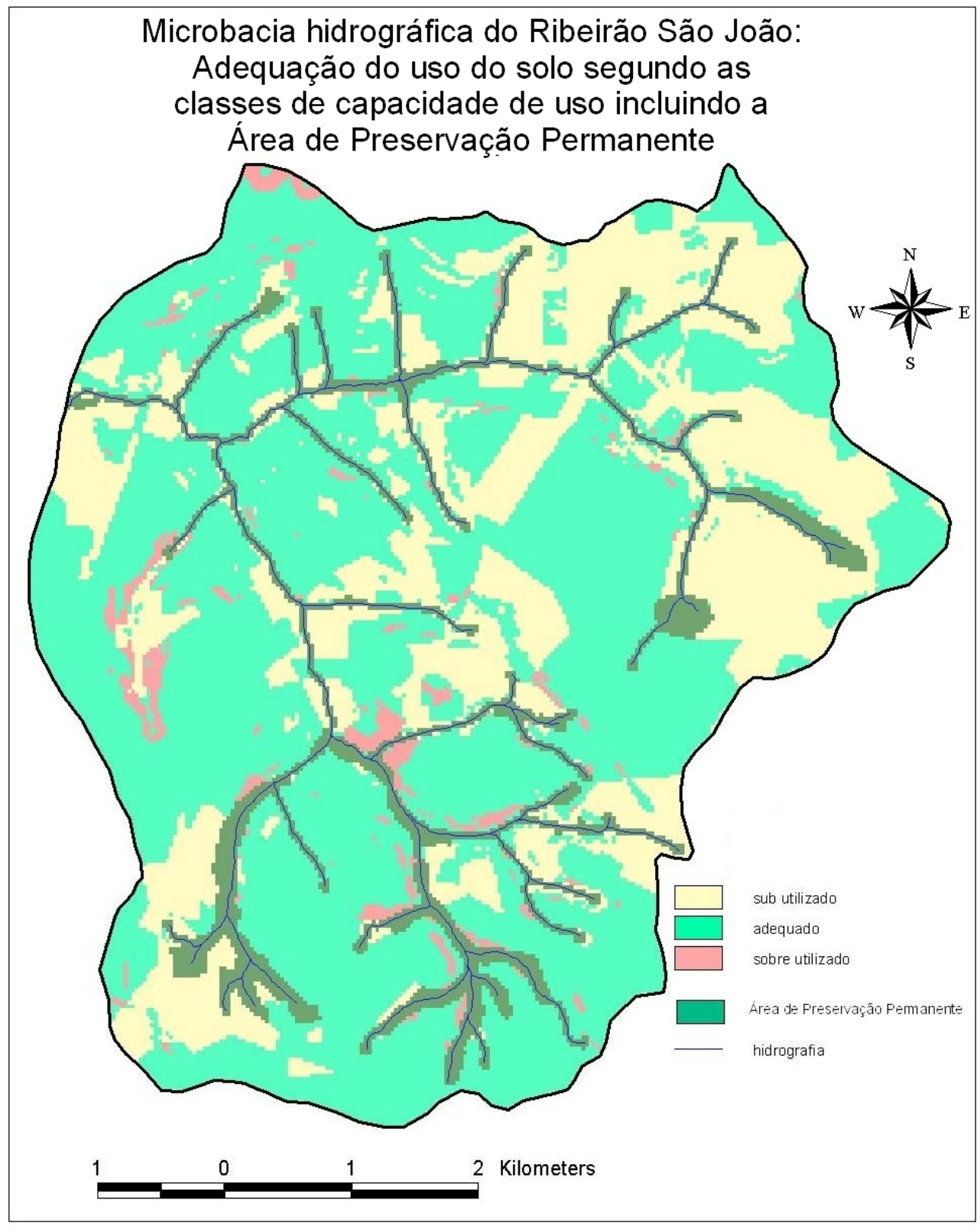

Figura 17 - Adequação de uso das terras destinadas à agricultura da microbacia do Ribeirão São João (Mineiros do Tietê, SP), com a delimitação das Áreas de Preservação Permanente. Ano: 2004 


\begin{tabular}{|c|c|c|}
\hline Categorias de Uso & Área (ha) & Área (\%) \\
\hline Sub-utilizado & $1.031,0$ & 28,2 \\
\hline Adequado & $2.157,0$ & 59,0 \\
\hline Sobre-utilizado & 95,1 & 2,6 \\
\hline APP & 372,9 & 10,2 \\
\hline Total & $\mathbf{3 . 6 5 6 , 0}$ & $\mathbf{1 0 0}$ \\
\hline
\end{tabular}

Quadro 17 - Adequação do Uso das Terras da microbacia do Ribeirão São João

No cenário convencional as Áreas de Preservação Permanente são consideradas no planejamento do uso da terra, entretanto foram discutidas separadamente, pois os critérios para a classificação do uso, em adequado ou não, consideram os fatores relacionados à legislação ambiental. As reservas legais, contudo, não foram inseridas no cenário convencional, embora estejam previstas no Código florestal (lei número 4.771/65), assim como as Áreas de Preservação Permanente, pois sua aplicação ainda não é vastamente respeitada nos planos de manejo integrado de microbacias .Este aspecto será melhor discutido mais adiante.

O uso das terras da microbacia hidrográfica pode ser considerado em 59,0 \% de sua área adequado, sob a ótica das potencialidades naturais da terra. Todavia, ocorre 28,2 \% de sub-utilização do uso e 2,6 \% de sobre-utilização. As porções da microbacia com subutilização do solo são representadas principalmente por terras com classe de capacidade de uso III utilizadas para pastagem e em menor proporção, para silvicultura (eucalipto) ou florestas nativas.

A elaboração desta carta não se mostrou suficiente para a classificação de adequação de uso de áreas da microbacia, pois não possibilitou uma avaliação realista de certas situações. Alguns exemplos são descritos a seguir. A área considerada subutilizada próxima às nascentes do Córrego do Borralho, como mostra a Figura 18, é ocupada por dois dos maiores fragmentos de vegetação nativa da microbacia. Esses fragmentos remanescentes de florestas estão localizados em uma propriedade pertencente à Prefeitura Municipal de Jaú, que tem como principal função a captação de água das nascentes do Córrego do Borralho para distribuição a população daquele 
município. Portanto, sob essa ótica, o uso do solo está adequado, pois a floresta tem a função de preservar a qualidade e a quantidade de água.

Um fragmento de Cerradão (Savana Florestada), que fica próximo (Figura 18) e ocupa toda a área de outra propriedade da Prefeitura de Jaú, está sendo preservado por também contribuir para a proteção dos recursos hídricos do local e por ser um tipo vegetacional especial, muito degradado em todo o Estado de São Paulo. Portanto, neste caso também o uso com vegetação nativa pode ser considerado adequado.

Outra situação semelhante ocorre em um fragmento de Floresta Estacional Semidecidual situado próximo a uma das nascentes que formam o Ribeirão São João (Figura 18), onde se pode observar algumas manchas de subutilização do solo. Esta mata ocupa uma área sensível, como demonstra o mapa de potencial natural de erosão, com afloramento do lençol freático. Dessa forma é possível concluir que a presença da vegetação nativa está adequada, pois essa área precisa estar adequadamente protegida, não podendo ser cultivada.

Os outros fragmentos florestais, fora de APP, que foram classificados como subutilização do solo, incluindo os já citados, na verdade poderão ser considerados parcialmente áreas de reserva legal, exigida pela legislação ambiental, que ainda não está sendo cumprida pelos produtores rurais da microbacia.

As áreas sobreutilizadas correspondem principalmente ao uso de terras classe IV, VI e VII com cana de açúcar, que ocorrem próximas aos cursos d’ água, agravando as possibilidades de degradação dos recursos naturais, em especial a água. 


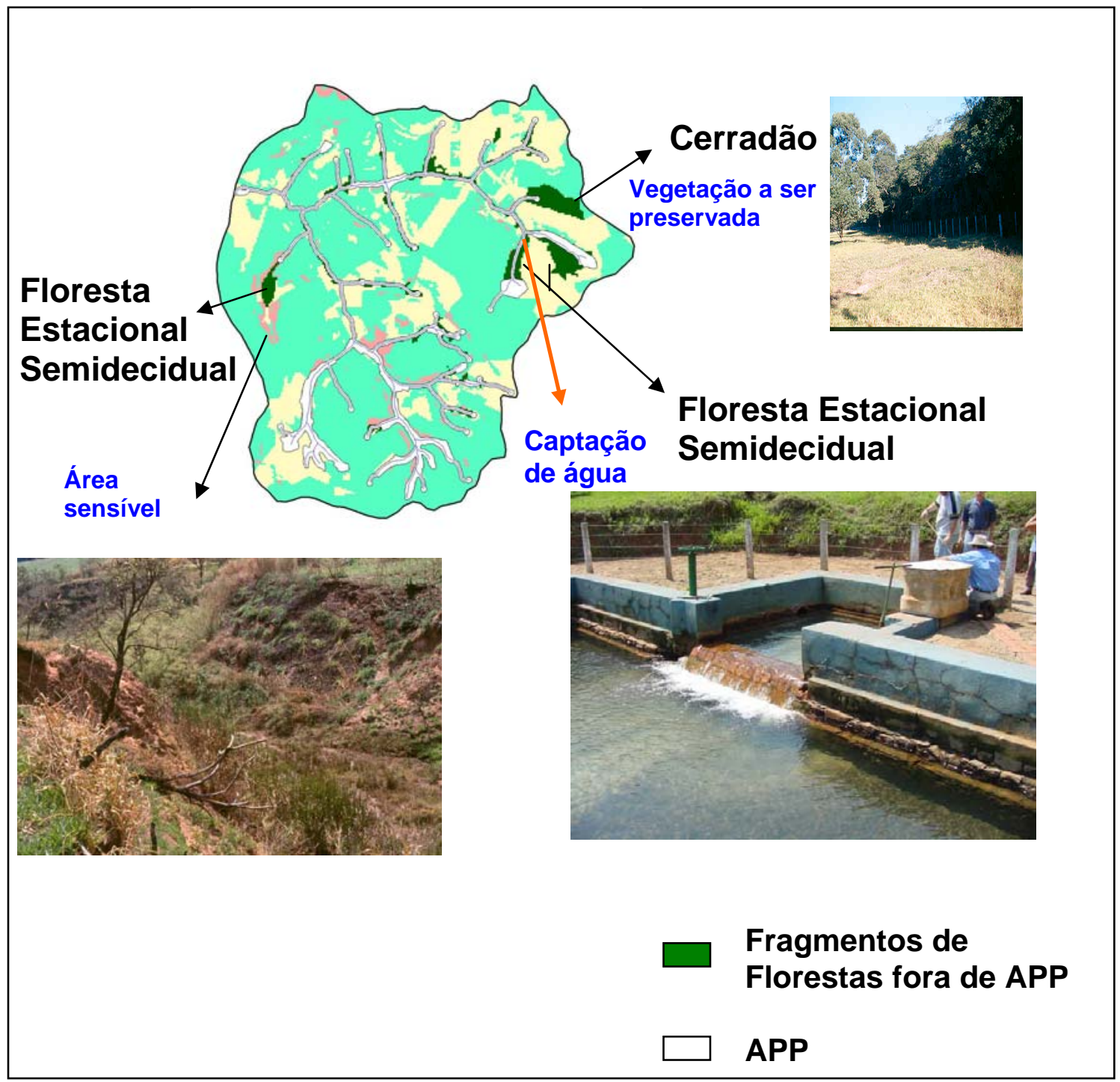

Figura 18 - Detalhe da localização e importância dos fragmentos florestais em alguns pontos da microbacia do Ribeirão São João (Mineiros do Tietê, SP) 


\section{- Potencial Natural de Erosão e Risco de Erosão}

O potencial natural de erosão foi calculado a partir da combinação dos planos de informação de erosividade da chuva, erodibilidade dos solos, comprimento de rampa e declividade. O risco de erosão foi obtido através de valores de perdas toleráveis para cada unidade de solo e os valores de potencial natural de erosão, considerando a prática mínima de plantio em nível.

Em análise ao Quadro 18 e à Figura 19, é possível concluir que a Microbacia do Ribeirão São João possui condições naturais de baixo potencial de perda de solo.

O potencial natural de erosão é muito baixo e baixo em 82,0\% da área, todavia os processos de erosão e de perda de solo são também influenciados, em grande parte, pelo manejo agrícola, que se não for apropriado pode também provocar perdas, mesmo que em menor quantidade.

As áreas com potencial natural de erosão moderado (11,6 \%) e alto e muito alto (6,4 \%), embora em pequenas proporções na microbacia, estão praticamente concentradas próximas aos cursos d' água, principalmente do Córrego do Borralho, o que intensifica a probabilidade de ocorrência de danos ambientais, principalmente de erosão das margens, reforçando a necessidade da completa proteção vegetal dessas áreas. São áreas sensíveis, que devido a fatores naturais, como solo e declividade, apresentam alto risco de erosão e conseqüentemente de comprometimento, principalmente da qualidade e quantidade das águas dos rios. Nesse caso, o uso das práticas incorretas de manejo agrícola e principalmente a ausência da mata ciliar podem acarretar impactos severos aos recursos naturais, em especial aos recursos hídricos da microbacia do Ribeirão São João. 


\begin{tabular}{|c|c|c|c|}
\hline \multicolumn{2}{|c|}{ Potencial natural de erosão } & \multicolumn{2}{c|}{ Área } \\
\hline Classes & Mg.ha $^{-1}$.ano & \\
\hline Muito baixo & $<500$ & 2306,9 & 63,1 \\
\hline Baixo & $500-1000$ & 691,0 & 18,9 \\
\hline Moderado & $1000-2000$ & 424,1 & 11,6 \\
\hline Alto & $2000-5000$ & 223,0 & 6,1 \\
\hline Muito alto & $>5000$ & 11,0 & 0,3 \\
\hline Total & & $3.656,0$ & 100 \\
\hline
\end{tabular}

Quadro 18 - Distribuição das classes do potencial natural de erosão da microbacia do Ribeirão São João 


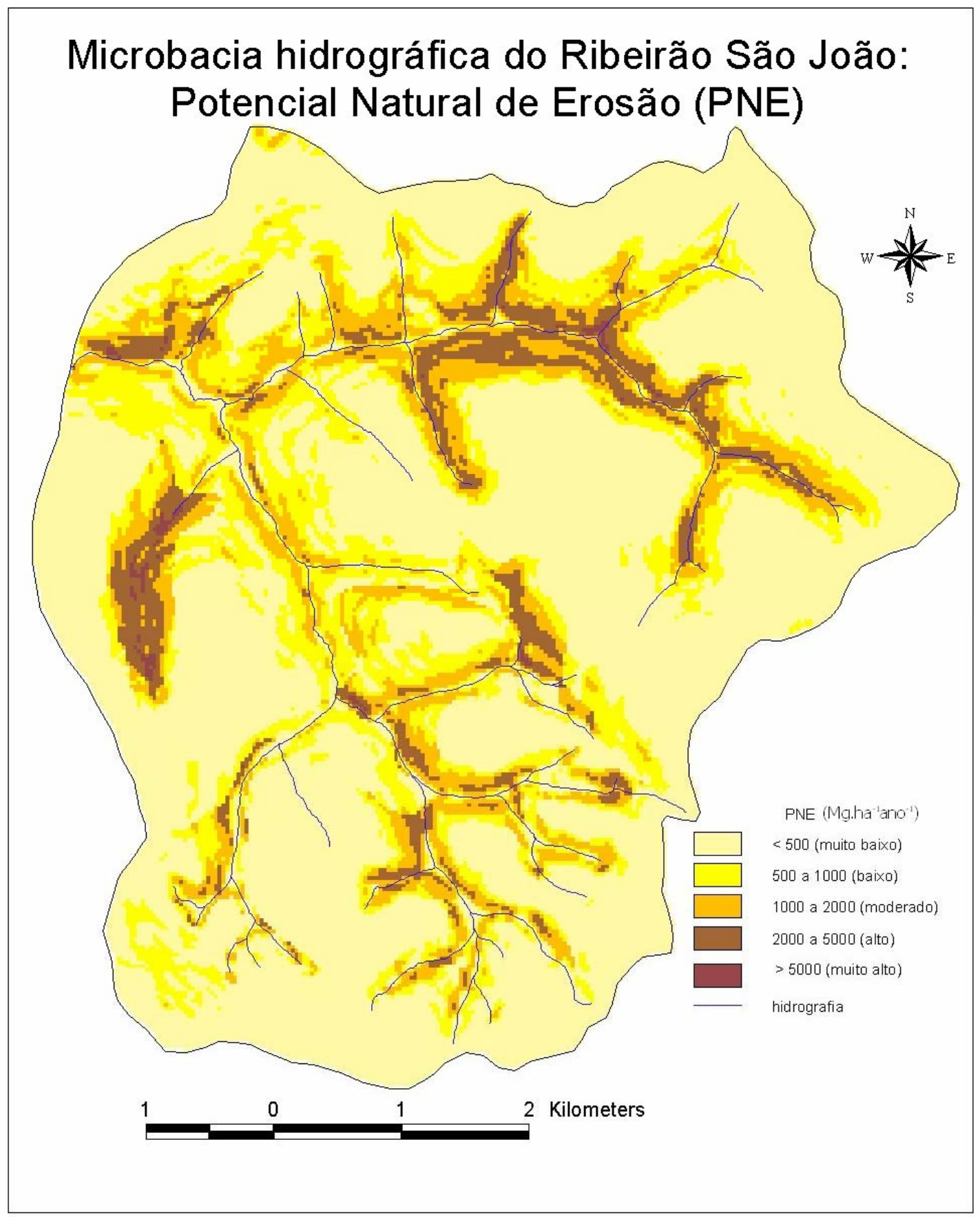

Figura 19 - Potencial natural de erosão da microbacia do Ribeirão São João (Mineiros do Tietê, SP). Ano: 2004 
O Quadro 19 e a Figura 20 apresentam a distribuição do risco de erosão da área de estudo mostrando que 76,9 \% da área apresenta risco de erosão baixo, ou seja, os valores de perda de solo são menores do que os valores de tolerância, portanto não apresentam probabilidade de ocorrência de graves impactos por erosão.

As classes de risco de erosão médio e alto representam uma área de 23,1 \%, distribuída homogeneamente por toda a microbacia, onde devem aparecer os problemas decorrentes da erosão, cujo custo para seu controle é muito elevado, sendo, portanto, áreas onde o uso atual deveria ser substituído por outros usos mais adequados, como a localização das áreas de reserva legal. As classes de risco de erosão baixo e moderado podem ser utilizadas com o uso atual, mas seu manejo deverá ser alterado visando reduzir as perdas de solo.

Na caracterização socioeconômica e no levantamento da percepção da qualidade ambiental da microbacia, 94 \% dos produtores rurais responderam que ocorre erosão em suas áreas. Estes dados comprovam a degradação do solo na microbacia, embora este processo erosivo pode estar acontecendo de forma suave em grande parte da área da microbacia, devido às características de baixo potencial de perda de solo e de risco de impactos por erosão. É possível também que o manejo agrícola, não considerado na metodologia de avaliação do potencial natural de erosão e do risco de erosão possa estar sendo inadequado, sob o ponto de vista das práticas conservacionistas. 


\begin{tabular}{|c|c|c|c|}
\hline \multicolumn{2}{|c|}{ Risco de erosão } & \multicolumn{2}{c|}{ Área } \\
\hline Classes & Valor UMP * & ha & $\%$ \\
\hline Baixo & $>0,02$ & $2.811,5$ & 76,9 \\
\hline Médio & $0,02-0,01$ & 402,2 & 11,0 \\
\hline Alto & $<0,01$ & 442,3 & 12,1 \\
\hline Total & & $\mathbf{3 . 6 5 6 , 0}$ & $\mathbf{1 0 0}$ \\
\hline
\end{tabular}

* Valores de uso manejo permissível, relacionados ao fator C da Equação Universal de Perdas de Solo para classificação de capacidade de uso das terras.

Quadro 19 - Risco de erosão na microbacia do Ribeirão São João (Mineiros do Tietê, $\mathrm{SP})$ 


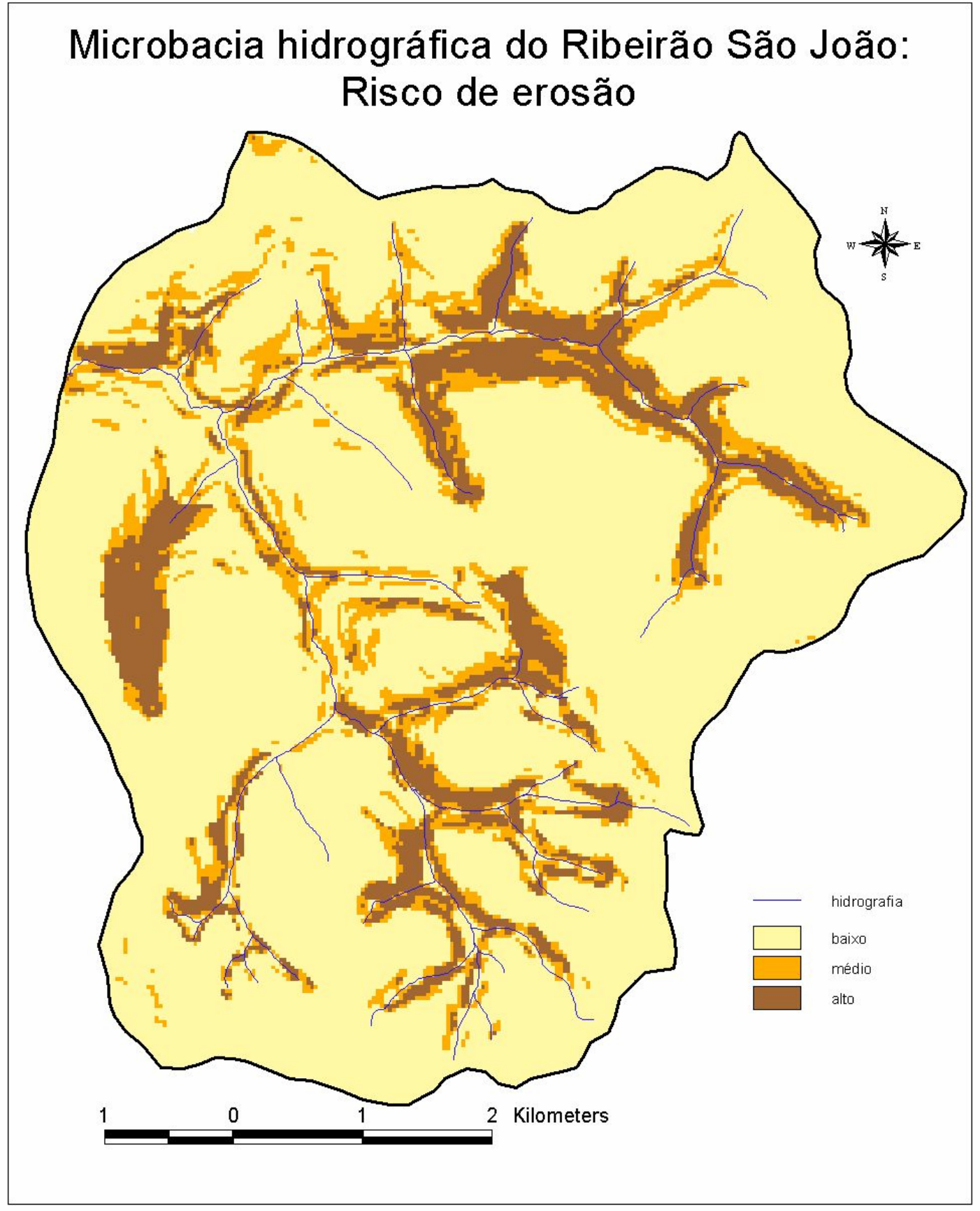

Figura 20 - Risco de erosão na microbacia do Ribeirão São João (Mineiros do Tietê, SP). Ano: 2004 
- Construção dos cenários convencionais (sem inclusão da zona

ripária): com a elaboração das cartas temáticas anteriores foi possível a representação dos cenários convencionais, aqueles largamente utilizados (como, por exemplo, nos programas estaduais de microbacias hidrográficas), que consideram as classes de capacidade de uso e o potencial natural de erosão, assim como a delimitação das áreas de preservação permanente, para o diagnóstico e o planejamento socioeconômico e ambiental da microbacia, destacando as áreas de risco e com maior sensibilidade, que requerem manejo diferenciado, conforme mostra as Figuras 21 e 22.

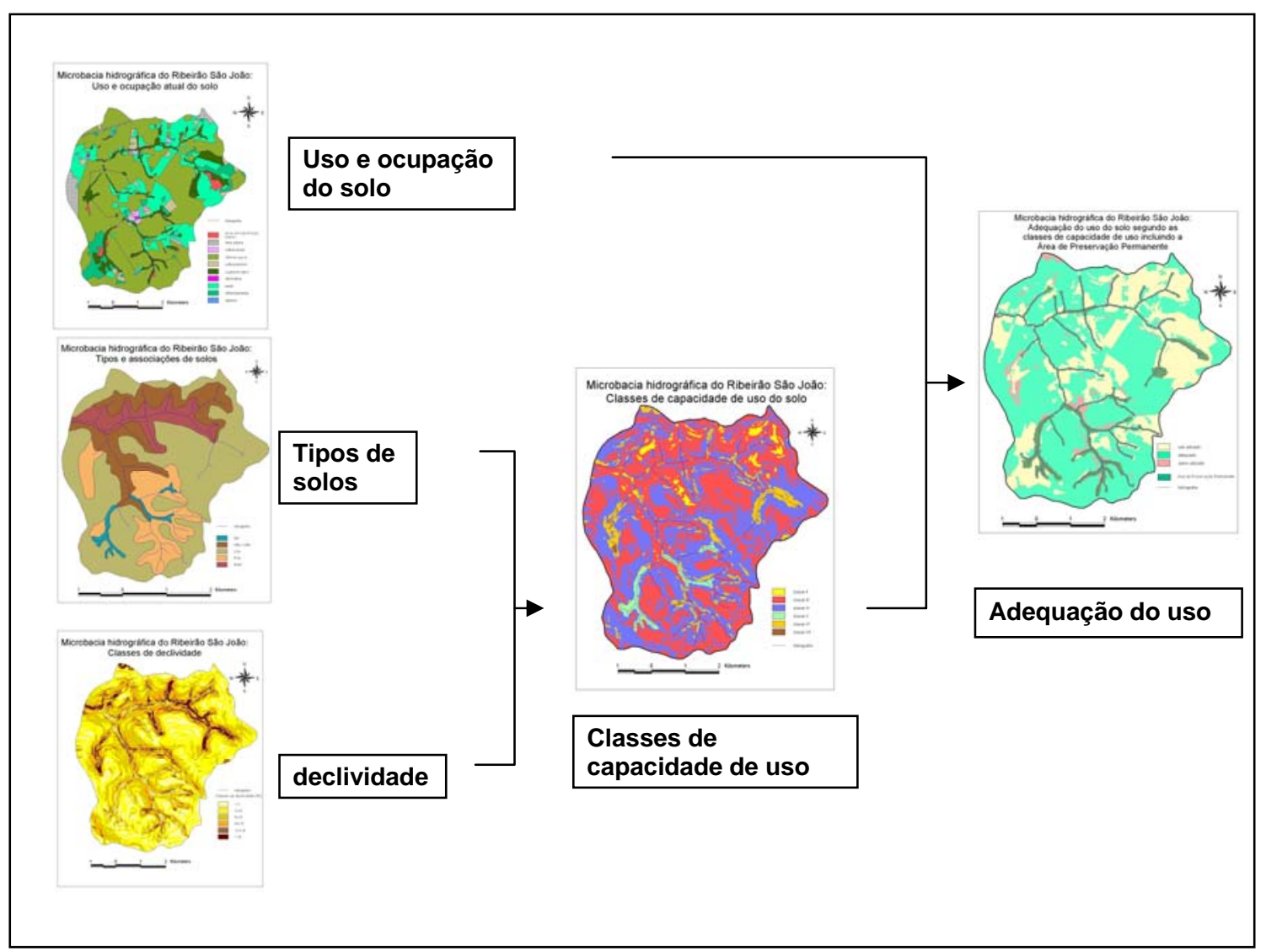

Figura 21 - Fluxograma ilustrativo da construção do cenário convencional que usa a determinação das classes de capacidade de uso para avaliação da adequação do uso do solo para a microbacia do Ribeirão São João (Mineiros do Tietê, $\mathrm{SP})$ 


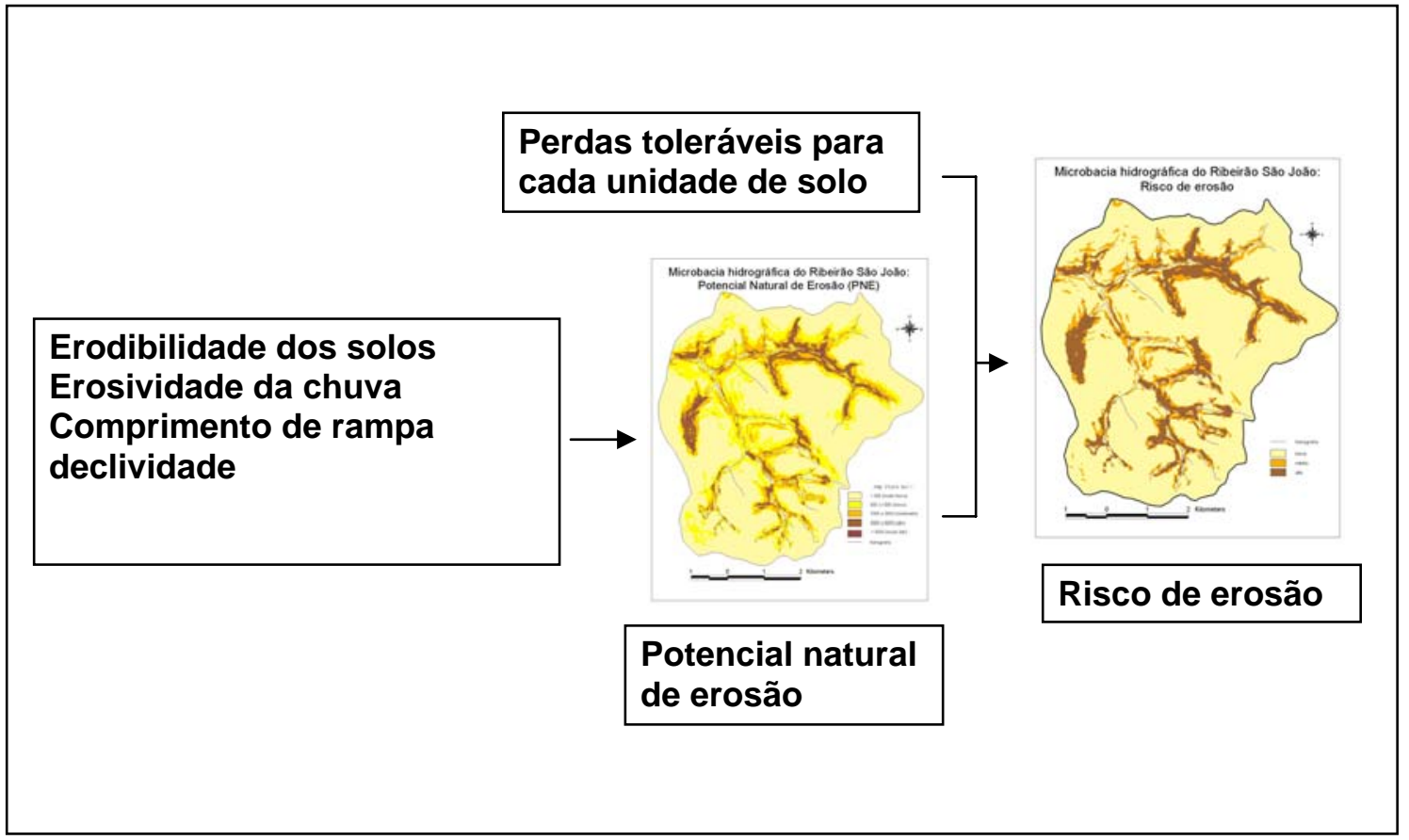

Figura 22 - Fluxograma ilustrativo da construção do cenário convencional que usa a determinação do potencial natural de erosão para avaliação das áreas de risco de impactos ambientais por erosão do solo para a microbacia do Ribeirão São João (Mineiros do Tietê, SP) 


\subsubsection{Composição dos cenários alternativos (com inclusão da zona ripária)}

Para a elaboração dos cenários alternativos ou propostos, podendo também serem chamados de cenários hidrológicos, isto é, aquele que considerada o manejo hidrológico e a inserção da zona ripária para análise e planejamento em microbacia, foi preciso gerar as seguintes cartas temáticas:

\section{- Áreas Variáveis de Afluência e Zona Ripária}

A Área Variável de Afluência (AVA) é uma zona ripária, porção saturada da microbacia que tem característica dinâmica devido à expansão e contração, dependendo da quantidade e intensidade das precipitações a qual está sujeita.

Nela prevalecem os processos de escoamento superficial de áreas saturadas durante a resposta hidrológica da microbacia a um evento de chuva. Em geral, encontram-se situadas ao longo dos cursos d’água e em suas cabeceiras, nas concavidades de terrenos para as quais convergem as linhas de fluxo e mesmo em porções de áreas saturadas encontradas em pontos elevados de encostas.

Em áreas planas, a zona ripária pode ser identificada através da presença de vegetação típica de terrenos que possuem temporária ou permanente influência hídrica, já que a metodologia para a delimitação das áreas variáveis de afluência se aplica a terrenos com declividade.

A vegetação ripária é o resultado da atuação diferencial da umidade e do encharcamento do solo na seletividade das espécies, como demonstram Rodrigues \& Shepherd (2000) em uma trabalho de revisão. Dessa maneira, a vegetação é indicadora das condições de saturação do solo e conseqüentemente da zona ripária.

Nas outras partes da microbacia, a água das chuvas tem a tendência de se infiltrar e assim formar o escoamento sub superficial, se o solo oferecer boas condições para que isso ocorra.

Na Microbacia do Ribeirão São João, os resultados obtidos mostram, conforme ilustrado na Figura 23, que a Área Variável de Afluência corresponde à 21,6 \% de toda sua extensão. 


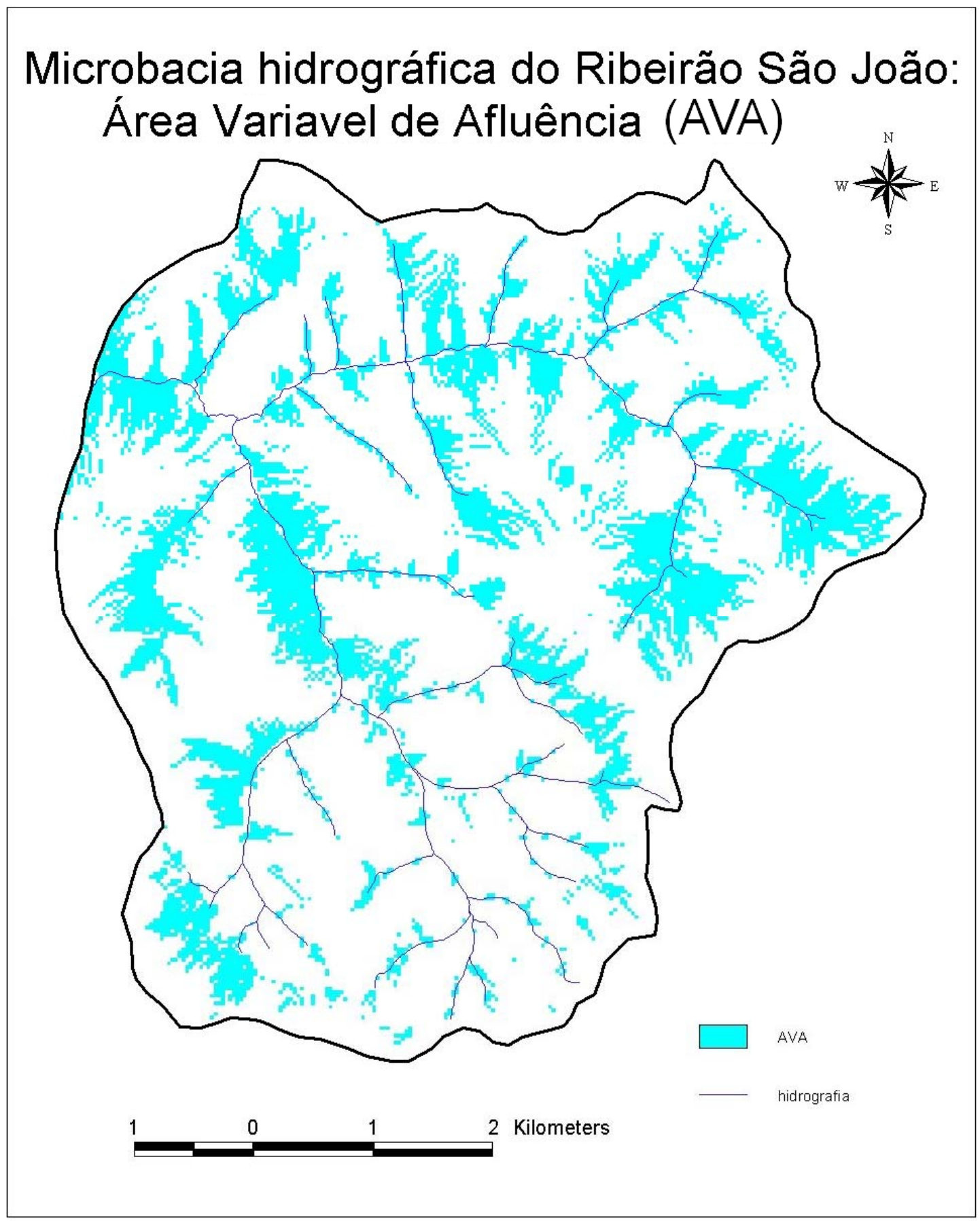

Figura 23 - Mapa de localização das áreas variáveis de afluência (AVA) que representam parte da zona ripária da microbacia do Ribeirão São João (Mineiros do Tietê, SP). Ano: 2004 
Com a realização do levantamento dos tipos vegetacionais dos fragmentos remanescentes da Microbacia do Ribeirão São João, foi possível o completo mapeamento da zona ripária (Figura 24). A zona ripária da microbacia, identificada através da localização das Áreas Variáveis de Afluência e da vegetação ripária possui área de 909,3 ha, o que corresponde à 24,9 \% da microbacia e está localizada conforme mostra a Figura 25.

O depoimento de 63 \% dos produtores rurais no levantamento socioeconômico e ambiental confirmando a ocorrência de enchentes nos cursos d’ água todos os anos nas épocas de chuva, evidencia a característica desta microbacia de possuir área ripária acima da média de $10 \%$ do total da bacia (Zakia, 1998).

Neste trabalho, a determinação da zona ripária foi feita utilizando-se Sistemas de Informações Geográficas para delimitação da AVA em análise conjunta da vegetação típica do ecossistema ripário.

Um aspecto prático desse zoneamento, além da demarcação precisa de áreas ripárias, consiste na possibilidade de se estabelecer manejo diferenciado em cada uma delas, visando diminuir impactos ambientais. As áreas ripárias são de nítida vocação de preservação ambiental para a proteção da qualidade da água.

Estudos com enfoque no ecossistema ripário oferecem informações úteis para respaldar o manejo integrado, incluindo a restauração das matas ciliares, com o objetivo de manter a saúde da microbacia hidrográfica, dentro das premissas da sustentabilidade.

A definição da localização da zona ripária é importante tanto do ponto de vista ecológico como de manejo. Restringir a ocupação agrícola nestas áreas que possuem função de filtro é uma decisão importante para o manejo (Naiman et al., 1997).

A identificação da zona ripária mostrou porque o local de captação de água pela prefeitura do município de Jaú, nas nascentes do Córrego do Borralho, é realmente abundante neste recurso. A delimitação das áreas ripárias pode também, através de estudos preliminares, subsidiar as decisões para o planejamento da expansão da área urbana do município, para a determinação do local de depósitos de lixo, para a localização dos traçados de estradas rurais, etc. 


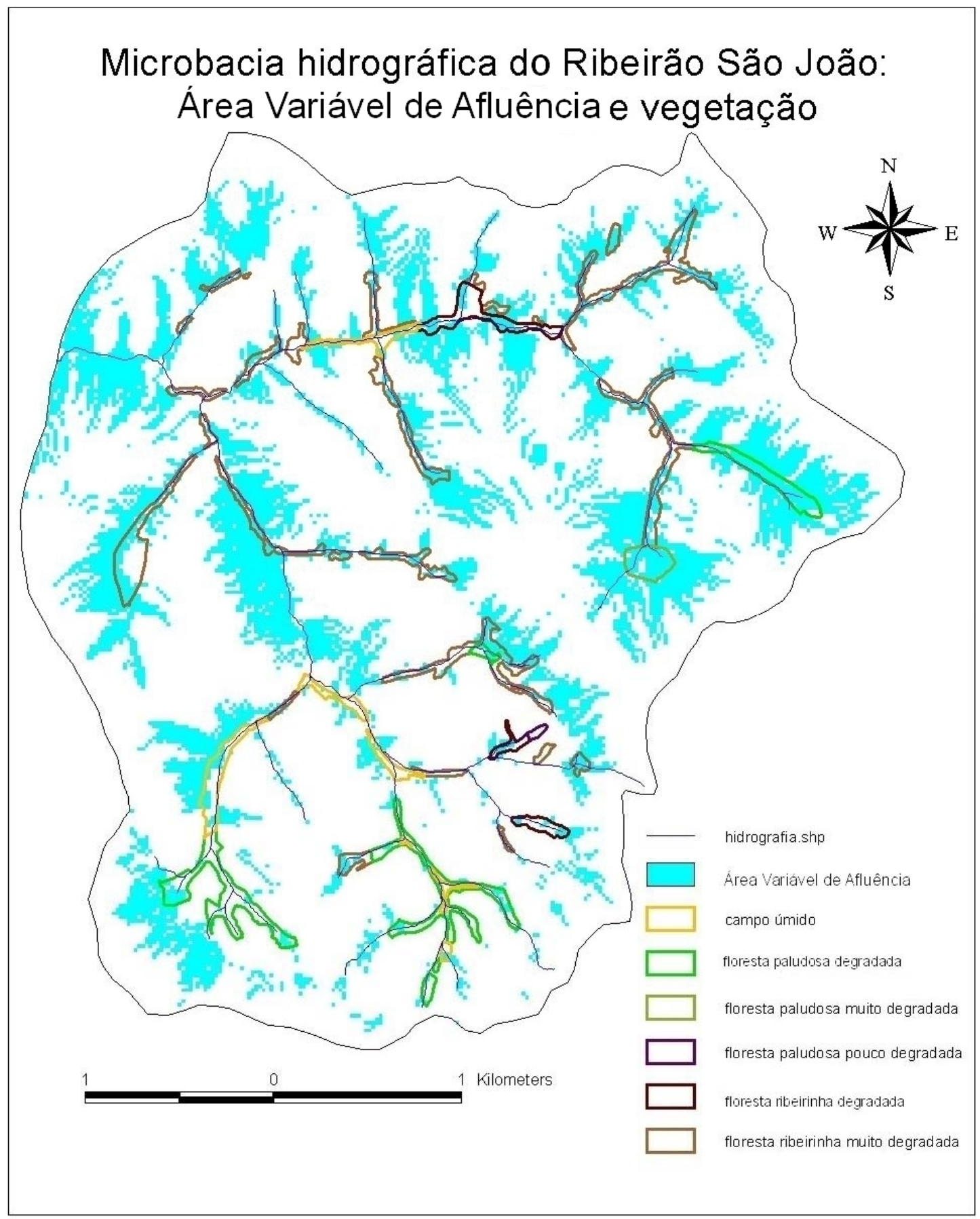

Figura 24 - Zona ripária da microbacia do Ribeirão São João (Mineiros do Tietê, SP) identificada através do levantamento dos tipos vegetacionais e do zoneamento altitudinal. Ano: 2004 


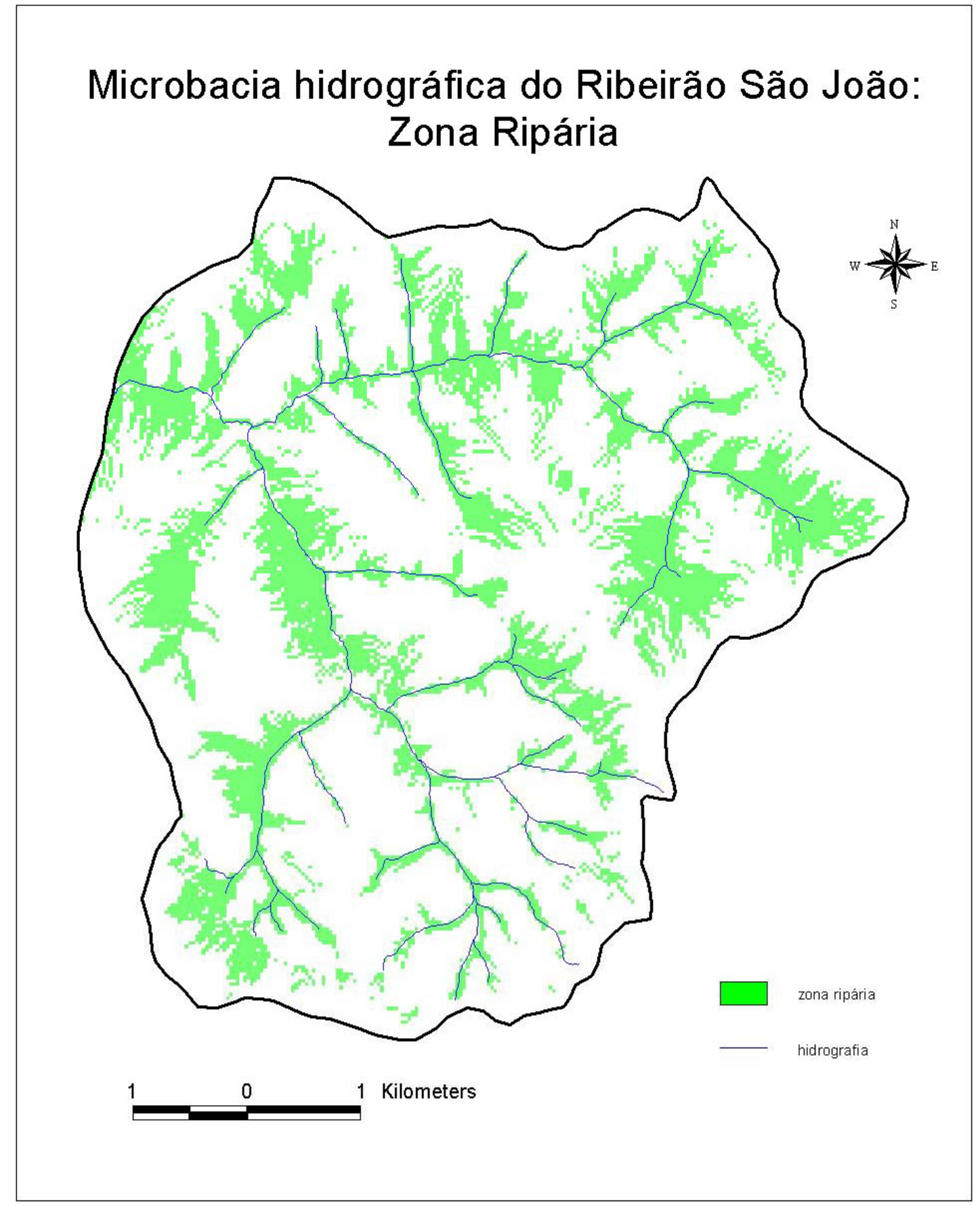

Figura 25 - Zona Ripária da microbacia do Ribeirão São João (Mineiros do Tietê, SP). Ano: 2004 


\section{- A construção do cenário alternativo ou hidrológico (com inclusão da}

zona ripária): após a preparação das cartas temáticas anteriormente apresentadas, a carta de zona ripária, incluindo a delimitação das Áreas de Preservação Permanente, foi sobreposta à carta de classes de capacidade de uso (Figura 26) e à carta de potencial natural de erosão (Figura 27), para possibilitar a construção do cenário hidrológico, conforme mostra a Figura 28.

A elaboração do cenário hidrológico, que tem como um dos resultados as Figuras 29 e 30, permite concluir que muitas áreas que apresentam pouca limitação ao cultivo intensivo, como as classes II e III, ou onde apenas não é recomendado o cultivo anual e sim as culturas semi perenes ou perenes, como as áreas de classe IV, podem, na realidade, ser áreas ripárias, de sensibilidade hídrica, fundamentais para a produção e qualidade da água da microbacia. O mesmo acontece em análise ao potencial natural de erosão. Áreas com muito baixo, baixo ou moderado potencial de perda de solo pelos processos erosivos, quando estudadas sob a ótica hidrológica, podem ser consideradas zonas ripárias da microbacia, o que restringe o uso e o manejo agrícola.

Segundo os Quadros 20 e 22, a área de preservação permanente, já considerada no cenário convencional para determinação da adequação de uso do solo, ocupa 10,2% da microbacia, a zona ripária (excluindo a porção que está localizada em APP) abrange 18 \% e o restante, isto é, a área destinada ao uso agrícola, representa 71,8 \%.

O Quadro 21 mostra as áreas ocupadas pelas classes de capacidade de uso na zona ripária (excluindo a porção localizada em APP) da microbacia do Ribeirão São João. Existem dentro dos limites da zona ripária 38,9 \% de classe III e 49,5 \% de classe IV.

O Quadro 23 apresenta o potencial natural de erosão na zona ripária (excluindo a porção localizada em APP), o que permite observar que 69,7 \% da área possui baixo ou muito baixo potencial de perda de solo por erosão e 17,2 \% representa moderado potencial natural de erosão.

A partir destes dados, é possível comprovar a importância da delimitação da zona ripária para o planejamento socioeconômico e ambiental da microbacia, que permite determinar áreas de risco ambiental sob uma nova abordagem, não apenas para um 
melhor aproveitamento agrícola da terra, nem tão pouco considerando apenas um aspecto ambiental, relacionado à características naturais do solo. Desconsiderando a zona ripária, algumas áreas fundamentais para a saúde da microbacia, para a sustentabilidade ambiental, e conseqüentemente social e econômica, estariam sendo avaliadas como sem restrição para cultivo intensivo ou sem limitações ambientais. O planejador estaria subestimando os riscos que poderiam ocorrer ao não considerar as áreas ripárias e o seu manejo, podendo desencadear a degradação ambiental da microbacia, comprometendo principalmente seus recursos hídricos.

Como mostra o Quadro 3, 78 \% dos produtores rurais desta microbacia, que utilizam a água dos cursos d'água, consideram que, devido à sua qualidade, a água raramente ou nunca pode ser utilizada, o que denuncia a degradação dos recursos hídricos na microbacia, embora 85 \% julguem a quantidade da água suficiente durante todo o ano. 


\begin{tabular}{|c|c|c|}
\hline Risco Ambiental & Área (ha) & Área (\%) \\
\hline Classe de capacidade de uso & & \\
\hline Classe II & 54,8 & 1,5 \\
\hline Classe III & $1.301,5$ & 35,6 \\
\hline Classe IV & $1.151,6$ & 31,5 \\
\hline Classe V & 11,1 & 0,3 \\
\hline Classe VI & 102,4 & 2,8 \\
\hline Classe VII & 3,6 & 0,1 \\
\hline Subtotal & $\mathbf{2 . 6 2 5 , 0}$ & $\mathbf{7 1 , 8}$ \\
\hline Zona Ripária + APP & 372,9 & 10,2 \\
\hline APP & 658,1 & 18,0 \\
\hline Zona Ripária (excluindo a porção da zona & & \\
\hline ripária que está localizada em APP) & $\mathbf{1 . 0 3 1 , 0}$ & 28,2 \\
\hline Subtotal & $\mathbf{3 . 6 5 6 , 0 0}$ & $\mathbf{1 0 0}$ \\
\hline Total & & \\
\hline
\end{tabular}

Quadro 20 - Risco ambiental na microbacia do Ribeirão São João, em hectares (ha) e em porcentagem (\%), referente às classes de capacidade de uso, áreas de preservação permanente e zona ripária 


\begin{tabular}{|c|c|c|c|}
\hline \multicolumn{4}{|c|}{$\begin{array}{r}\text { Classes de capacidade de uso na zona ripári } \\
\text { APP) }\end{array}$} \\
\hline $\begin{array}{c}\text { Classe de capacidade } \\
\text { de uso }\end{array}$ & $\begin{array}{l}\text { Área da zona } \\
\text { ripária (ha) }\end{array}$ & $\begin{array}{l}\text { Área da zona } \\
\text { ripária (\%) }\end{array}$ & $\begin{array}{l}\text { Área da microbacia } \\
\qquad(\%)\end{array}$ \\
\hline Classe II & 9,2 & 1,4 & 0,3 \\
\hline Classe III & 256,0 & 38,9 & 7,0 \\
\hline Classe IV & 325,8 & 49,5 & 8,9 \\
\hline Classe V & 3,9 & 0,6 & 0,1 \\
\hline Classe VI & 59,9 & 9,1 & 1,6 \\
\hline Classe VII & 3,3 & 0,5 & 0,1 \\
\hline Total & 658,1 & 100 & 18 \\
\hline
\end{tabular}

Quadro 21- Áreas, em ha e em porcentagem, das classes de capacidade de uso na zona ripária, excluindo a porção da zona ripária que está localizada em APP, da microbacia do Ribeirão São João 


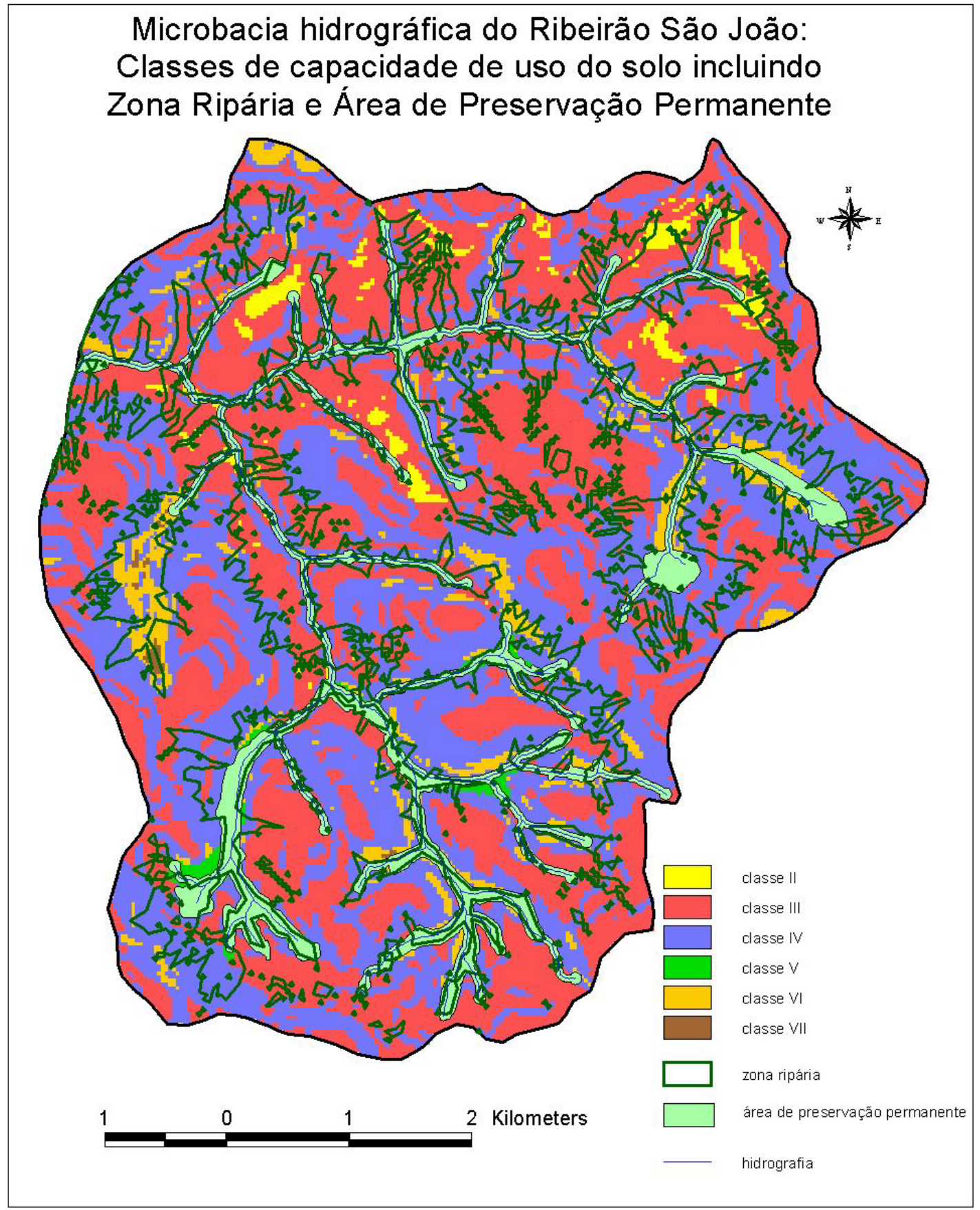

Figura 26 - Carta resultante da sobreposição das cartas de classes de capacidade de uso, zona ripária e Área de Preservação Permanente da microbacia do Ribeirão São João (Mineiros do Tietê, SP). Ano: 2004 


\begin{tabular}{|c|c|c|}
\hline Risco Ambiental & Área (ha) & Área (\%) \\
\hline Potencial Natural de Erosão & & \\
\hline Muito baixo & $1.901,1$ & 52,0 \\
\hline Baixo & 413,1 & 11,3 \\
\hline Moderado & 219,4 & 6,0 \\
\hline Alto & 87,8 & 2,4 \\
\hline Muito alto & 3,6 & 0,1 \\
\hline Subtotal & $\mathbf{2 . 6 2 5 , 0}$ & $\mathbf{7 1 , 8}$ \\
\hline Zona Ripária + APP & 372,9 & 10,2 \\
\hline APP & 658,1 & 18,0 \\
\hline Zona Ripária (excluindo a porção da zona & & \\
ripária que está localizada em APP) & $\mathbf{1 . 0 3 1 , 0}$ & $\mathbf{2 8 , 2}$ \\
\hline Subtotal & $\mathbf{3 . 6 5 6 , 0}$ & $\mathbf{1 0 0}$ \\
\hline Total & & \\
\hline
\end{tabular}

Quadro 22 - Risco ambiental na microbacia do Ribeirão São João, em ha e em porcentagem, referente ao potencial natural de erosão, áreas de preservação permanente e zona ripária

\begin{tabular}{|ccc|c|}
\hline \multicolumn{4}{|c|}{ Potencial natural de erosão na zona ripária (excluindo a porção localizada em APP) } \\
\hline Potencial Natural de Erosão & Área (ha) & Área (\%) & Área da microbacia (\%) \\
\hline Muito baixo (< 500) & 280,4 & 42,6 & 7,7 \\
\hline Baixo (500 a 1000) & 178,3 & 27,1 & 4,9 \\
\hline Moderado (1000 a 2000) & 113,2 & 17,2 & 3,1 \\
\hline Alto (2000 a 5000) & 80,9 & 12,3 & 2,2 \\
\hline Muito alto (> 5000) & 5,3 & 0,8 & 0,1 \\
\hline Total & $\mathbf{6 5 8 , 1}$ & $\mathbf{1 0 0}$ & $\mathbf{1 8}$ \\
\hline
\end{tabular}

Quadro 23 - Áreas, em ha e em porcentagem, do potencial natural de erosão na zona ripária, excluindo a porção da zona ripária que está localizada em APP, da microbacia do Ribeirão São João 


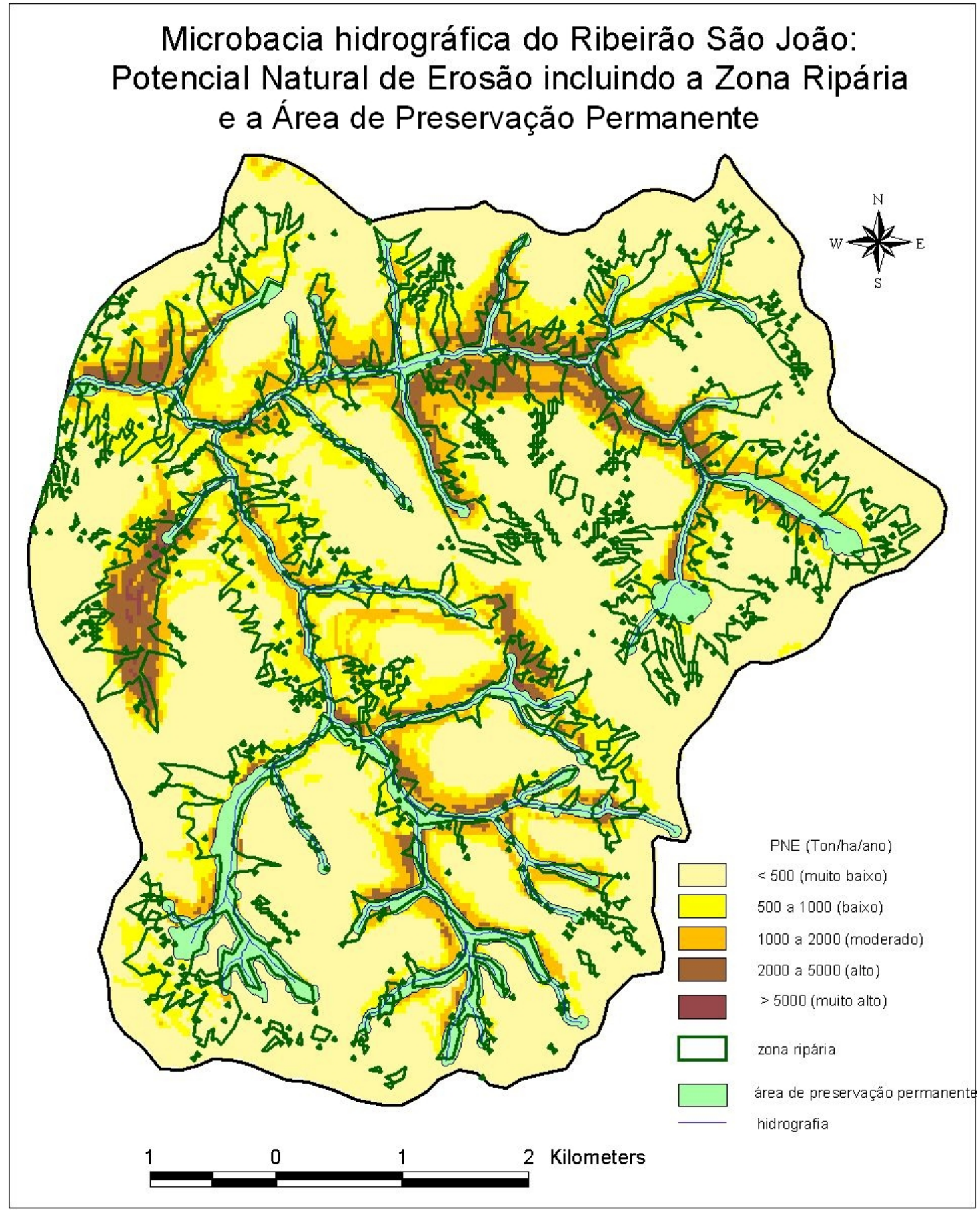

Figura 27 - Carta resultante da sobreposição das cartas de potencial natural de erosão, zona ripária e Área de Preservação Permanente da microbacia do Ribeirão São João (Mineiros do Tietê, SP). Ano: 2004 


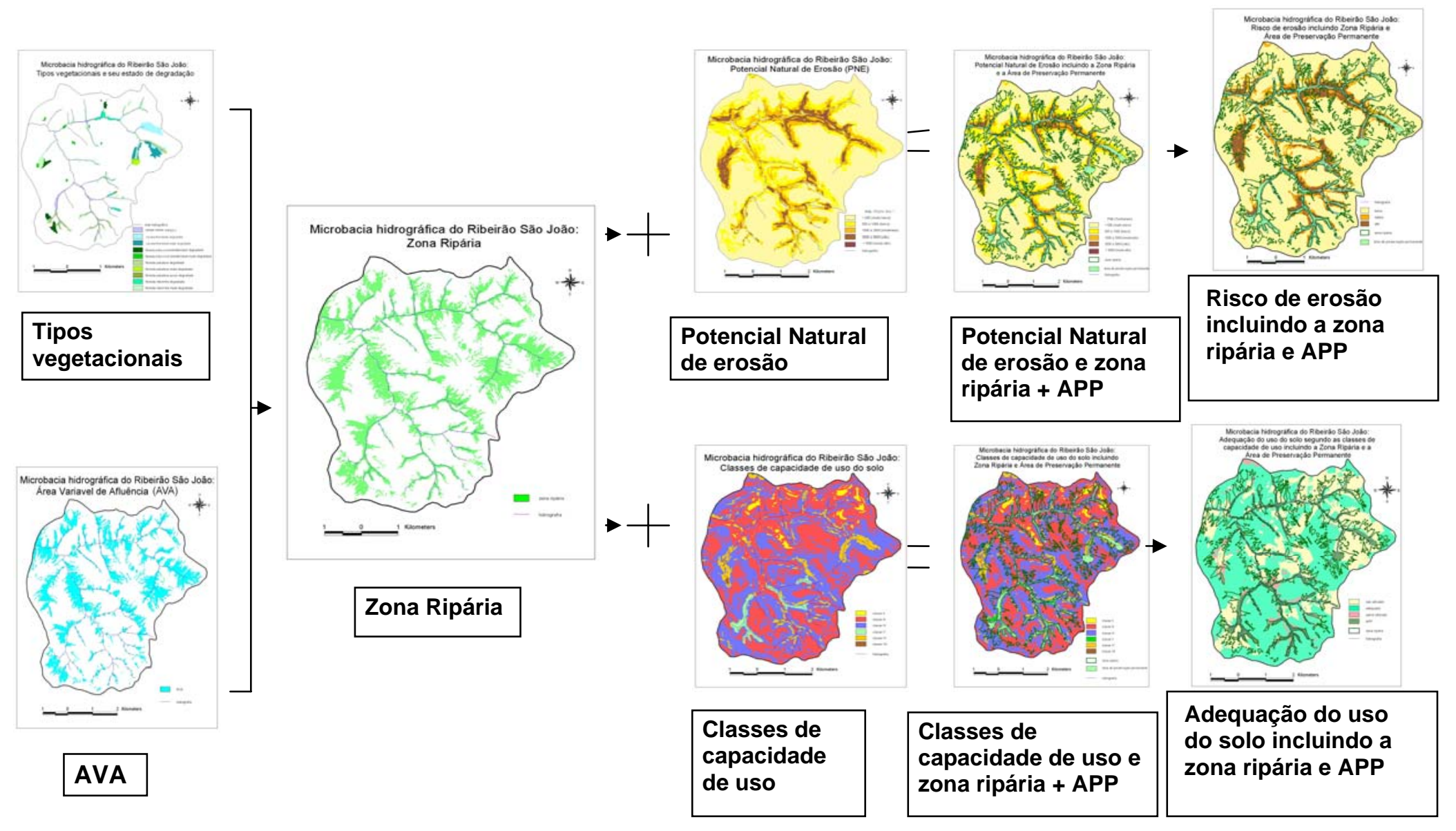

Figura 28 - Fluxograma ilustrativo da construção dos cenários alternativos com inclusão da zona ripária nos cenários convencionais para o planejamento sócio-ambiental da microbacia do Ribeirão São João (Mineiros do Tietê, SP) 
Com a construção do cenário hidrológico, é possível elaborar as cartas finais para o estudo dos riscos ambientais da Microbacia do Ribeirão São João.

A Figura 29 mostra o resultado da sobreposição das cartas de adequação do uso incluindo a zona ripária e a área de preservação permanente, que representa a proposta de inserir análise hidrológica no cenário convencional de planejamento socioeconômico e ambiental de microbacias.

Segundo o Quadro 24, a microbacia possui 49,5 \% de sua área com o uso do solo adequado, 20,4 \% com sub utilização do uso e apenas 1,9 \% com sobre utilização. A sub utilização ocorre onde a classe de capacidade de uso III está sendo utilizada para pastagem e em menor proporção, para silvicultura (eucalipto) ou florestas nativas. A sobre utilização é representada principalmente pela ocupação das classes de capacidade de uso V, VI e VII por cana de açúcar.

A Figura 30 apresenta o resultado da combinação das cartas de risco de erosão, incluindo a zona ripária e a área de preservação permanente, também simboliza a proposta de integrar a análise hidrológica e o planejamento usual de microbacias hidrográficas. É importante destacar que a inserção das áreas de preservação permanente faz parte do cenário convencional, pois sua proteção é uma exigência legal.

O Quadro 25 mostra que 60,2 \% da área da microbacia é considerada de baixo risco de erosão, 6,2 \% possui moderado risco e somente 5,4 \% compreende alto risco.

Os dados obtidos com a metodologia convencional indicam que 59,0 \% da área está ocupada com uso adequado, 28,2 \% com sub utilização do uso e 2,6 \% com sobre utilização, 76, 9 \% da área da microbacia possui baixo risco de erosão, 11,0 \% moderado e 12,1 \% alto risco. Esta alteração pode induzir o planejador a tomar medidas impróprias para a proteção das áreas que representam maiores riscos para a saúde da microbacia. Os métodos e premissas do modo como se avalia os riscos ambientais da microbacia indicam as medidas que deverão ser adotadas com a intenção de se precaver os impactos ou se restaurar as áreas degradadas. 


\begin{tabular}{|c|c|c|}
\hline Risco Ambiental & Área (ha) & Área (\%) \\
\hline Adequação do uso do solo & & 20,4 \\
\hline Sub utilizado & 745,7 & 49,5 \\
\hline Adequado & $1.808,6$ & 1,9 \\
\hline Sobre utilizado & 70,7 & $\mathbf{7 1 , 8}$ \\
\hline Subtotal & $\mathbf{2 . 6 2 5 , 0}$ & 10,2 \\
\hline Zona Ripária + APP & 372,9 & 18,0 \\
\hline APP & 658,1 & $\mathbf{2 8 , 2}$ \\
\hline Zona Ripária (excluindo a porção da zona & & $\mathbf{1 0 0}$ \\
\hline Súria que está localizada em APP) & $\mathbf{1 . 0 3 1 , 0}$ & $\mathbf{3 . 6 5 6 , 0}$ \\
\hline Total & & Ribtotal \\
\hline
\end{tabular}

Quadro 24 - Risco ambiental na microbacia do Ribeirão São João, em ha e em porcentagem, referente ao potencial natural de erosão, áreas de preservação permanente e zona ripária 


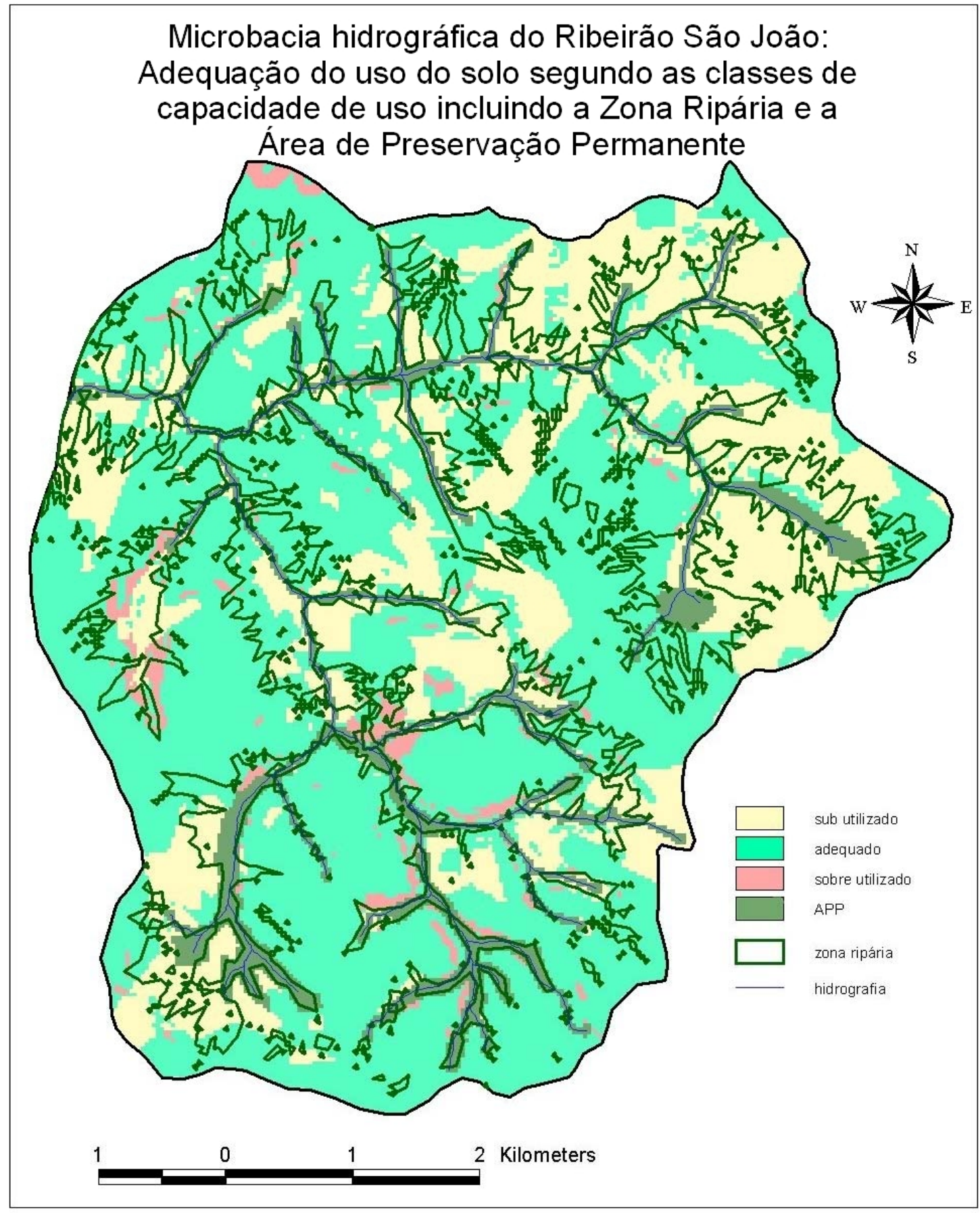

Figura 29 - Carta de adequação do uso do solo, incluindo zona ripária e áreas de preservação permanente da microbacia do Ribeirão São João (Mineiros do Tietê, SP). Ano: 2004 


\begin{tabular}{|c|c|c|}
\hline Risco Ambiental & Área (ha) & Área (\%) \\
\hline Risco de Erosão & & \\
\hline Baixo & $2.201,7$ & 60,2 \\
\hline Moderado & 225,1 & 6,2 \\
\hline Alto & 198,2 & 5,4 \\
\hline Subtotal & $\mathbf{2 . 6 2 5 , 0}$ & $\mathbf{7 1 , 8}$ \\
\hline Zona Ripária + APP & 372,9 & 10,2 \\
\hline APP & 658,1 & 18,0 \\
\hline $\begin{array}{c}\text { Zona Ripária (excluindo a porção da zona } \\
\text { ripária que está localizada em APP) }\end{array}$ & & $\mathbf{2 8 , 2}$ \\
\hline Subtotal & $\mathbf{1 . 0 3 1 , 0}$ & $\mathbf{1 0 0}$ \\
\hline Total & $\mathbf{3 . 6 5 6 , 0}$ & \\
\hline
\end{tabular}

Quadro 25 - Risco ambiental na microbacia do Ribeirão São João, em ha e em porcentagem, referente ao risco de erosão, áreas de preservação permanente e zona ripária 


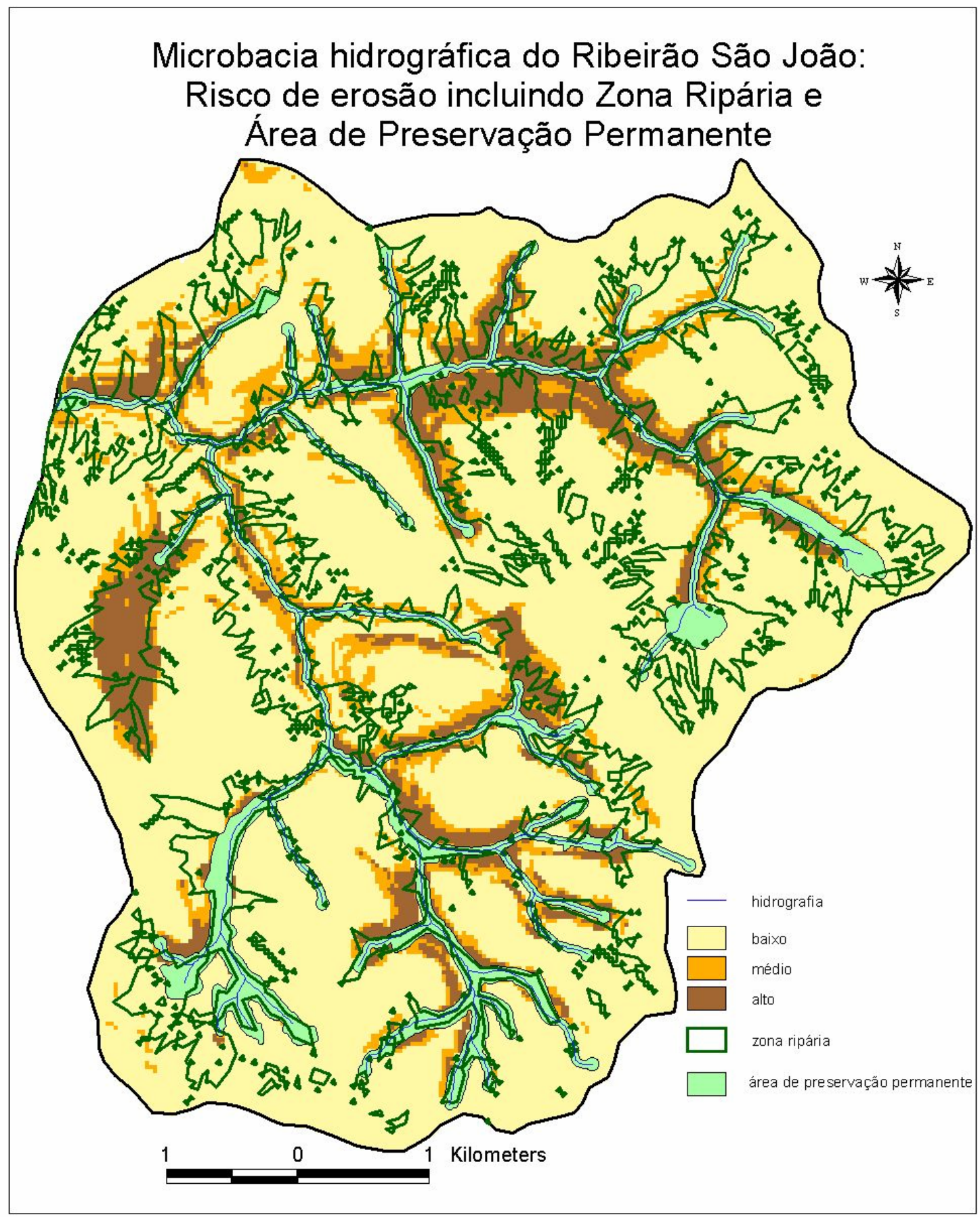

Figura 30 - Carta de risco de erosão incluindo a zona ripária e área de preservação permanente da microbacia do Ribeirão São João (Mineiros do Tietê, SP). Ano: 2004 
A construção do cenário hidrológico corresponde aos principais anseios da comunidade rural da microbacia detectados através do diagnóstico e planejamento participativos, isto é a preservação dos recursos hídricos da microbacia.

Algumas correlações considerando a zona ripária podem favorecer o planejamento das ações de manejo, relacionando a legislação ambiental, a estrutura fundiária, o manejo agrícola e as estradas rurais, além das políticas públicas que regem os planos de microbacias.

\section{- A zona ripária e a legislação ambiental}

A largura estipulada pela legislação ambiental para a ocupação das matas ciliares pode eventualmente ser apropriada para proteger os cursos d’ água, mas não é suficiente para resguardar áreas hidrologicamente sensíveis da microbacia.

Na Microbacia do Ribeirão São João, apenas 251,2 ha, ou seja, 27,6 \% da zona ripária está inserida em Área de Preservação Permanente (APP) (Figura 31), conseqüentemente resguardada pelas leis ambientais. Além desta porção protegida, 78,4 ha da zona ripária, que representa 8,6 \%, estão ocupados por vegetação nativa localizada fora de APP, não correndo risco de degradação pelo uso agrícola intensivo. Nesta microbacia, 72,2 \% da zona ripária (incluindo a porção localizada em APP) estão sendo utilizadas para agricultura, correndo risco de degradação. 


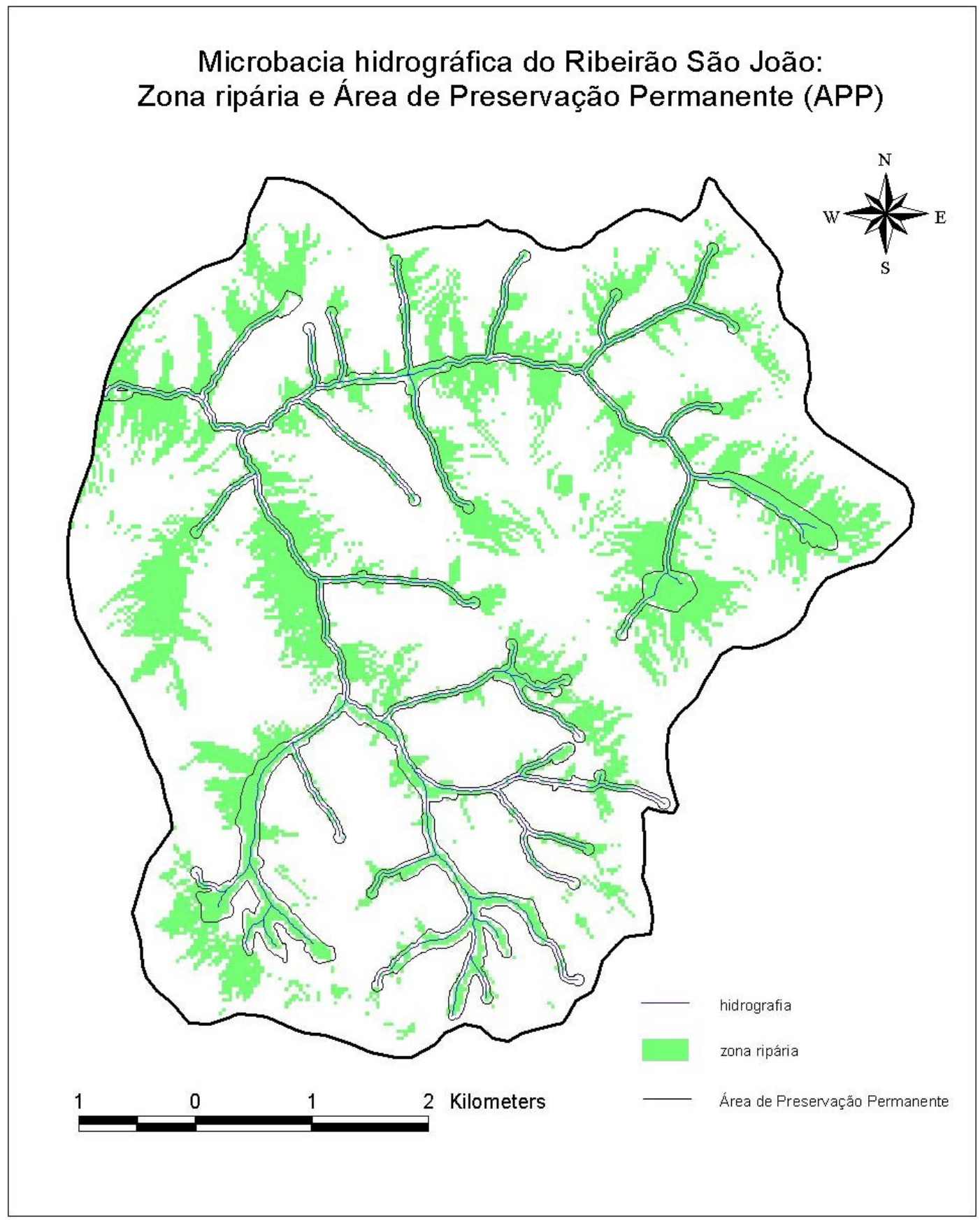

Figura 31 - Zona ripária e área de preservação permanente da microbacia do Ribeirão São João (Mineiros do Tietê, SP). Ano: 2004 
Para a proteção destas áreas existe a possibilidade da aplicação de lei ambiental que trata sobre as reservas legais.

Segundo o Código Florestal (lei número 4.771/65), as reservas legais são apresentadas da seguinte forma, segundo os artigos 16 e 44 (artigos com redação determinada pela Medida Provisória 2.166-67/2001):

Art.16. As florestas e outras formas de vegetação nativa, ressalvadas as situadas em área de preservação permanente, assim como aquelas não sujeitas ao regime de utilização limitada ou objeto de legislação específica, são suscetíveis de supressão, desde que sejam mantidas, a título de reserva legal, no mínimo:

I - oitenta por cento, na propriedade rural situada em área de floresta localizada na Amazônia Legal;

II - trinta e cinco por cento, na propriedade rural situada em área de cerrado localizada na Amazônia Legal, sendo no mínimo vinte por cento na propriedade e quinze por cento na forma de compensação em outra área, desde que esteja localizada na mesma microbacia, e seja averbada nos termos do § 7o deste artigo;

III - vinte por cento, na propriedade rural situada em área de floresta ou outras formas de vegetação nativa localizada nas demais regiões do País; e

IV - vinte por cento, na propriedade rural em área de campos gerais localizada em qualquer região do País.

$\S 20$ A vegetação da reserva legal não pode ser suprimida, podendo apenas ser utilizada sob regime de manejo florestal sustentável, de acordo com princípios $e$ critérios técnicos e científicos estabelecidos no regulamento, ressalvadas as hipóteses previstas no $\S 3$ o deste artigo, sem prejuízo das demais legislações específicas.

§ Зo Para cumprimento da manutenção ou compensação da área de reserva legal em pequena propriedade ou posse rural familiar, podem ser computados os plantios de 
árvores frutíferas ornamentais ou industriais, compostos por espécies exóticas, cultivadas em sistema intercalar ou em consórcio com espécies nativas.

$\S 40$ A localização da reserva legal deve ser aprovada pelo órgão ambiental estadual competente ou, mediante convênio, pelo órgão ambiental municipal ou outra instituição devidamente habilitada, devendo ser considerados, no processo de aprovação, a função social da propriedade, e os seguintes critérios e instrumentos, quando houver:

I - o plano de bacia hidrográfica;

II - o plano diretor municipal;

III - o zoneamento ecológico-econômico;

IV - outras categorias de zoneamento ambiental; $e$

V - a proximidade com outra Reserva Legal, Área de Preservação Permanente, unidade de conservação ou outra área legalmente protegida.

Art. 44. O proprietário ou possuidor de imóvel rural com área de floresta nativa, natural, primitiva ou regenerada ou outra forma de vegetação nativa em extensão inferior ao estabelecido nos incisos I, II, III e IV do art. 16, ressalvado o disposto nos seus $\S \S 5$ e e 60 , deve adotar as seguintes alternativas, isoladas ou conjuntamente:

I - recompor a reserva legal de sua propriedade mediante o plantio, a cada três anos, de no mínimo 1/10 da área total necessária à sua complementação, com espécies nativas, de acordo com critérios estabelecidos pelo órgão ambiental estadual competente;

II - conduzir a regeneração natural da reserva legal; $e$

III - compensar a reserva legal por outra área equivalente em importância ecológica e extensão, desde que pertença ao mesmo ecossistema e esteja localizada na mesma microbacia, conforme critérios estabelecidos em regulamento. 
No plano de manejo da microbacia as áreas ripárias localizadas fora de APP correspondem à 658,1 ha, sendo que 78,4 ha já estão ocupadas por vegetação nativa. Estas áreas poderiam ser mantidas e resguardadas com a implementação das reservas legais, as quais devem abranger aproximadamente $20 \%$ da microbacia (ou $20 \%$ de cada propriedade rural, como estabelecido no Código Florestal), isto é, 731,2 ha, proporcionando assim a proteção às zonas de sensibilidade hídrica. Desta maneira, a área coberta com vegetação nativa na microbacia do Ribeirão São João passaria de 318,1 ha para 1.104,1 (APP + reserva legal) e a zona ripária estaria completamente protegida. Entretanto, é claro, outros fatores devem ser considerados nesta tomada de decisão como, por exemplo, a presença de construções rurais nas áreas ripárias (casas, estábulos, tulhas, depósitos, etc.), de estradas, a situação dos pequenos produtores rurais, além da agropecuária, principal atividade econômica do local. É preciso, então, avaliar cada propriedade agrícola, cada caso, mas sempre tendo a dinâmica da microbacia como o elemento orientador desta análise.

A análise que considera a mesoescala (microbacia), assim como a microescala (propriedades rurais) para a localização das reservas legais, está prevista na lei quando cita os critérios para a sua localização (art. 16, § $4^{\circ}$ e art. 44, III ) e representa um avanço para a preservação das áreas sensíveis sob a ótica da mesoescala, isto é, a microbacia hidrográfica.

Sob esta mesma abordagem, poderia também ser considerada reserva legal outras áreas de zona ripária, sem cobertura da vegetação nativa, localizadas fora de APP.

No Estado de São Paulo a Resolução 47, que altera e amplia a Resolução SMA 21, de 21-11-2001, fixa orientação para o reflorestamento heterogêneo de áreas degradadas e dá providências correlatas, devido à constatação quanto à baixa diversidade vegetal das áreas reflorestadas com espécies nativas no Estado. No seu artigo $3^{\circ}$, citado a seguir, a resolução 47 trata das áreas que devem ser priorizadas para a execução dos trabalhos de recuperação florestal:

Art. $3^{\circ}$ - Na execução dos trabalhos de recuperação florestal, deverão ser priorizadas as seguintes áreas: 
a) as áreas consideradas de preservação permanente pela Lei Federal 4771/65, em especial aquelas localizadas em nascentes e olhos d'água;

b) de interligação de fragmentos florestais remanescentes na paisagem regional (corredores ecológicos);

c) de elevado potencial de erodibilidade.

Para o planejamento da localização das reservas legais é importante considerar, em conjunto, as áreas que favorecem a formação de corredores ecológicos, a proximidade com áreas protegidas legalmente e as áreas de sensibilidade ambiental, tais como aquelas com alto risco de erosão, classes de capacidade de uso V, VI, VII, VIII, e principalmente as zonas ripárias, devido ao importante serviço ambiental que realizam.

Para este tipo de planejamento é importante conhecer também a distribuição fundiária na microbacia, o que fundamenta uma análise mais realista das relações ambientais e legais com os produtores rurais.

\section{- A zona ripária e a estrutura fundiária da microbacia}

Os produtores rurais são considerados pessoas-chave para a preservação e recuperação ambiental, visando à transição à sustentabilidade no meio rural, pois além de utilizarem os recursos naturais para produzirem alimentos e outros importantes produtos demandados pela sociedade e de serem proprietários de grande parte das áreas ocupadas por remanescentes de ecossistemas, possuem possivelmente alguma cumplicidade com a natureza.

A degradação ambiental é provocada tanto por pequenos como por grandes produtores rurais. Os grandes produtores desenvolvem uma agricultura monocultural, de produtos para exportação, com uso intensivo do solo e dependência da aplicação de insumos químicos. Já os pequenos produtores, pressionados por uma política agrícola direcionada ao mercado externo e a sistemas de produção capitalistas, sentem dificuldades na própria sustentação econômica, podendo, conseqüentemente, exercer uma pressão indevida sobre os recursos naturais ou então, engrossar o fluxo migratório para as cidades. 
Os pequenos produtores, diante da situação de pouco espaço para a produção, de poucos recursos financeiros e de mão de obra, etc. convivem com uma dificuldade maior para se enquadrarem na legislação ambiental, referente à Área de Preservação Permanente e à Reserva Legal.

Sob o enfoque do desenvolvimento da agricultura pelos proprietários rurais, um importante aspecto abordado pela legislação é o conceito de função social da propriedade. Segundo a Constituição de 1988 o direito de propriedade só é reconhecido quando sua função social e ambiental forem cumpridas. Assim a função ambiental é elemento marcante do direito de propriedade.

Milaré (2004) cita a Lei 10.406, de 10-01-2002. art. 1.228, §1, que prescreve que tal direito “ deve ser exercitado em consonância com as suas finalidades econômicas e sociais e de modo que sejam preservados, de conformidade com o estabelecido em lei especial, a flora, a fauna, as belezas naturais, o equilíbrio ecológico e o patrimônio histórico e artístico, bem como evitada a poluição do ar e das águas”.

Segundo o art. 186 da Constituição, a função social da propriedade rural será cumprida quando, entre outros requisitos, utilizar adequadamente os recursos naturais disponíveis e preservar o meio ambiente. A função social e ambiental da propriedade rural sustenta a possibilidade de imposição ao proprietário de recuperar a vegetação em áreas de preservação permanente e reserva legal, mesmo que ele não tenha sido o responsável pelo desmatamento (Milaré, 2004).

A posse de bens coletivos, o desfrute privado daquilo que é de todos, representa responsabilidade perante toda a sociedade, sem isto, a apropriação torna-se usurpação (Derani, 2002).

Esta é uma abordagem que está em harmonia com o paradigma da sustentabilidade, considerando a dimensão ambiental e os valores sociais integrados à cadeia econômica da produção. A idéia de função social da propriedade inclui a concepção de que os recursos naturais são patrimônio da nação, das gerações presentes e futuras, independente da apropriação de parcela deste território e de suas riquezas naturais por parte de um indivíduo. 
A preservação dos recursos hídricos e, portanto da zona ripária está inserida no contexto desta discussão.

A Figura 32 representa a distribuição da zona ripária nas propriedades rurais. Algumas propriedades numeradas não são consideradas na análise da estrutura fundiária desta microbacia, pois possuem apenas uma porção insignificante dentro de seus limites. Este é o caso das propriedades de número 10, 106, 107, 111, 114, 115, 116, 120, 121, 122. Desta forma, a microbacia possui dentro de seus divisores de águas 111 propriedades rurais, como descrito na caracterização socioeconômica.

É possível concluir, através da Figura 32 e da tabela em anexo (Anexo A) que apenas 04 propriedades, as de número 67, 104, 105 e 113 (excluindo as propriedades que não foram consideradas por possuírem quase a totalidade de suas áreas em outra microbacia, como mencionado acima) não possuem área em zona ripária. Por outro lado as propriedades de número 5, 6, 9, 11, 14, 38, 41, 55, 57, 58, 80, 87, 93 e 117 estão com 50 \% ou mais de suas áreas ocupadas por zona ripária. Em média, 26,1 \% das áreas das propriedades rurais da microbacia se encontram em zona ripária. Estas áreas poderiam ser protegidas pela Área de Preservação Permanente e pelo estabelecimento das reservas legais, que devem corresponder à 20 \% da área da propriedade ou, em média, da microbacia, como visto anteriormente.

Nas propriedades que possuem grande parte de suas áreas em zona ripária, como as citadas acima, onde é desenvolvida a agricultura ou a pecuária, o manejo relacionado à estas atividades deveria ser diferenciado, como discutido a seguir. 


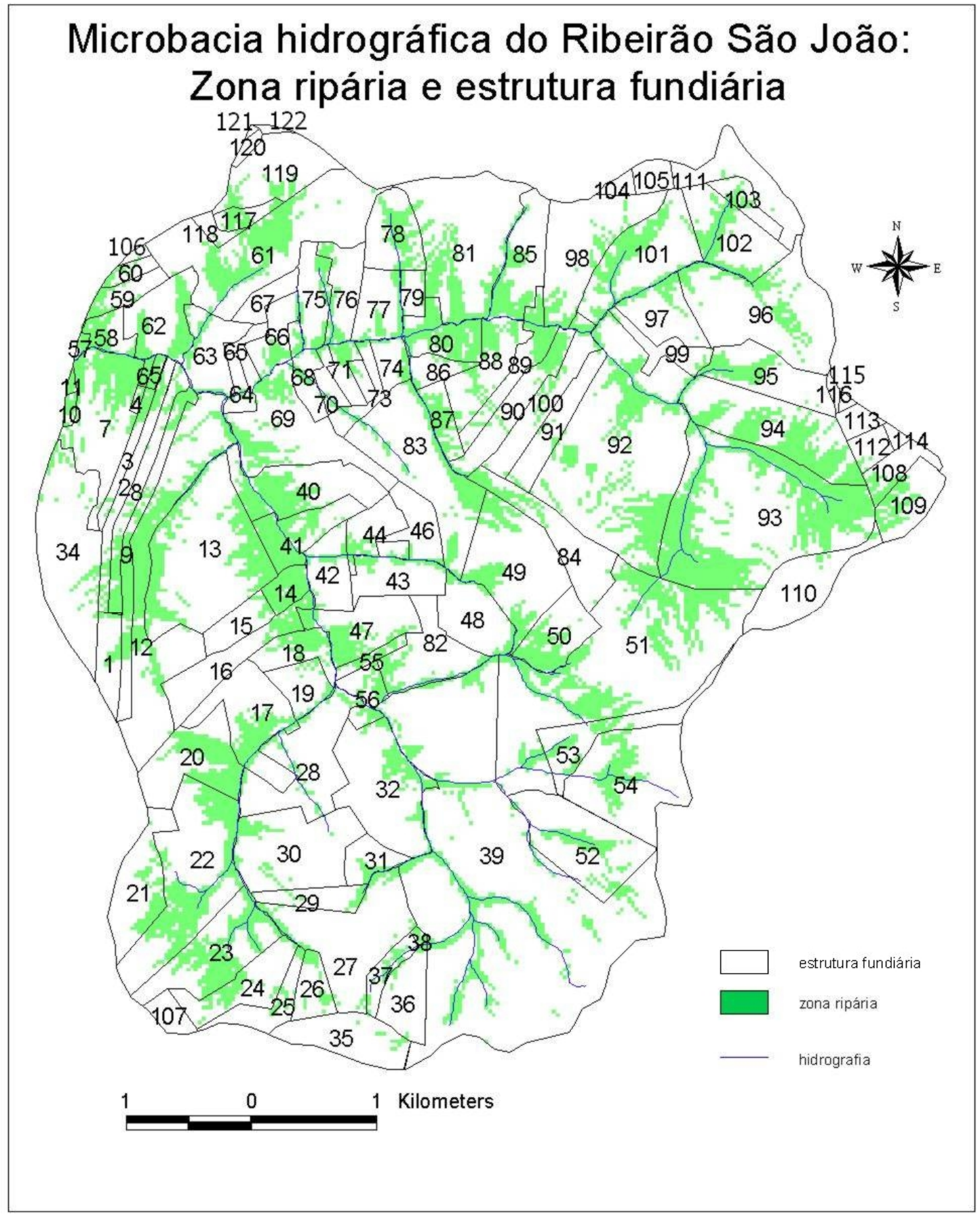

Figura 32 - Delimitação da zona ripária e distribuição fundiária na microbacia do Ribeirão São João (Mineiros do Tietê, SP). Ano: 2.004 


\section{- Zona ripária, o uso atual do solo e o manejo agrícola na microbacia}

A porção zona ripária que não estiver protegida pela legislação ambiental, por não estar localizada em Áreas de Preservação Permanente ou sem possibilidades de ser considerada reserva legal, deveria ter um manejo diferenciado de acordo com seu uso e ocupação. De acordo com o Quadro 26 a zona ripária está ocupada principalmente por cana de açúcar (39,8 \% de sua área), pastagem (20,4 \% de sua área) e vegetação nativa (27,8 \% de sua área, sendo 8,6 \% localizados fora de APP).

\begin{tabular}{|c|c|c|}
\hline Usos do solo & Área (ha) & \% do total \\
\hline Represas & 3,6 & 0,4 \\
\hline Reflorestamento & 63,6 & 7,0 \\
\hline Pastagem & 185,5 & 20,4 \\
\hline Olericultura & 1,8 & 0,2 \\
\hline Vegetação nativa & 252,8 & 27,8 \\
\hline Cultura perene & 16,4 & 1,8 \\
\hline Cana de açúcar & 361,9 & 39,8 \\
\hline Cultura anual & 8,2 & 0,9 \\
\hline Área urbana & 9,1 & 1,0 \\
\hline Área em recuperação & 6,4 & 0,7 \\
\hline Total & $\mathbf{9 0 9 , 3}$ & $\mathbf{1 0 0}$ \\
\hline
\end{tabular}

Quadro 26 - Uso e ocupação do solo em zona ripária da microbacia do Ribeirão São João

A monocultura da cana de açúcar, da forma intensiva como vem sendo praticada na microbacia, como mostrado pelo levantamento socioeconômico e ambiental, pode representar o comprometimento da busca de uma agricultura sustentável, pois aspectos relacionados a essa cultura promovem a degradação ambiental e social.

Certas atividades do manejo agrícola da cana de açúcar são altamente impactantes, com destaque para o preparo convencional do solo, a utilização intensiva de agrotóxicos (herbicidas principalmente), a aplicação indiscriminada de vinhaça no 
solo, a queimada anual (Ometto, 2000), a ausência de cobertura vegetal do solo em épocas chuvosas causada pela colheita realizada entre outubro e dezembro, a eliminação da diversidade biológica, a concentração de terras e etc.

A não adequação das práticas agrícolas canavieiras em zonas ripárias representa risco de degradação.

Devido à falta de manejo adequado, principalmente relacionado à proteção e conservação do solo, as pastagens também oferecem alto risco de degradação da zona ripária, pela possibilidade de ocorrência de processos erosivos do solo e de assoreamento dos rios. Isso também ocorre com as culturas anuais e com a cafeicultura, quando o manejo inadequado não inclui as práticas conservacionistas, além de causar baixa produção e conseqüentemente pouca cobertura vegetal do solo. A silvicultura também pode causar degradação, mas com menos intensidade, pois promove uma melhor cobertura do solo. As áreas de zona ripária próximas aos bairros urbanos periféricos correm alto risco potencializado pela ocorrência de escoamento superficial formado nas áreas impermeáveis do s bairros marginais.

Neste caso um manejo diferenciado deve ser aplicado, como por exemplo, o plantio direto da cana de açúcar, a colheita da cana crua, colheita em épocas secas, a minimização ou não utilização de agrotóxicos, realização de rotação de culturas na reforma do canavial. Para as pastagens é recomendado a alternância entre períodos de pastejo e descanso para manejar e manter a vegetação da pastagem, manutenção do número de animais de acordo ou abaixo da capacidade de suporte das espécies forrageiras e obtenção de uma distribuição uniforme dos animais do pasto. As Áreas de Preservação Permanente degradadas devem ser restauradas.

É possível confirmar, através dos indicadores visuais, a ocorrência de diferentes fatores de degradação em áreas da microbacia, gerados pelo manejo predatório dos recuros naturais e por práticas agrícolas inadequadas (Figura 33). 


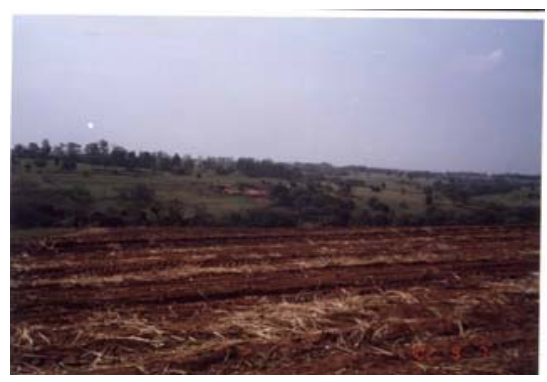
Áreas descobertas após colheita da
cana
Cultura anual (arroz) em avançado processo erosivo devido à ausência de práticas conservacionistas

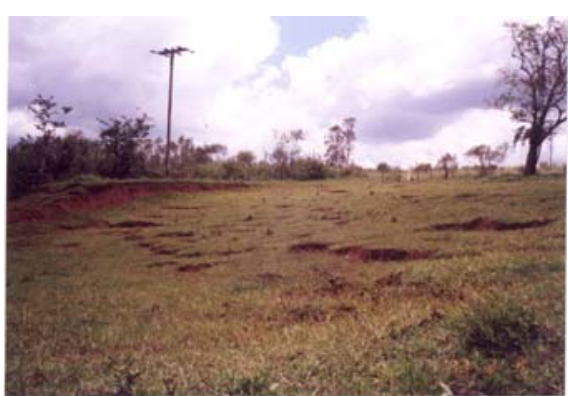

Pastagem degradada sem práticas conservacionistas
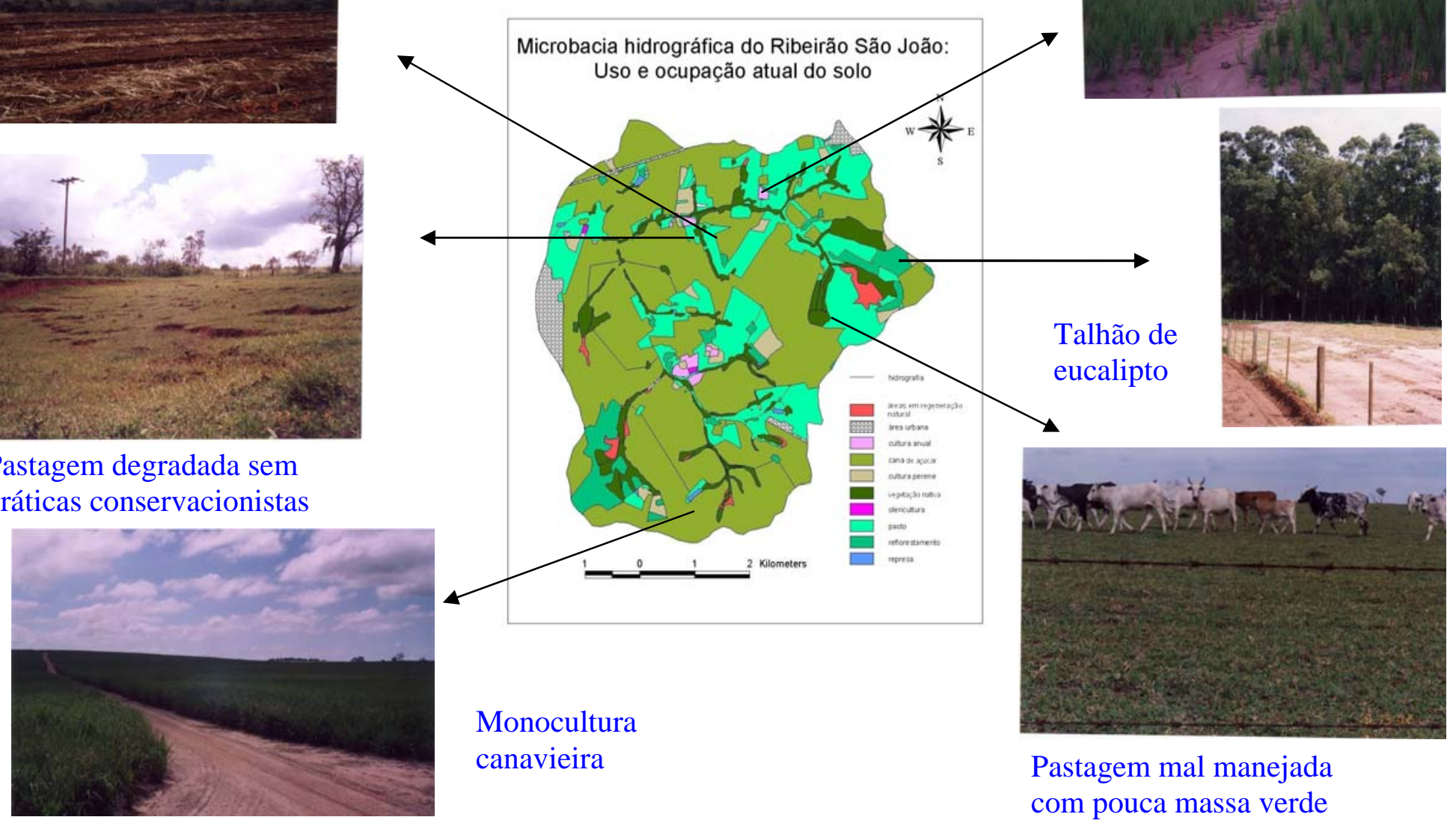
canavieira

Pastagem mal manejada com pouca massa verde

Figura 33 - Detalhes das áreas onde ocorre degradação ambiental resultante do manejo agrícola inadequado na Microbacia Hidrográfica do Ribeirão são João (Mineiros do Tietê, SP). Ano: 2004 
Segundo Rodrigues \& Gandolfi (2000), em todo o mundo, a agricultura sempre foi e continua sendo o principal fator degradador dos ecossistemas ciliares, através da expansão da fronteira agrícola ou de práticas agrícolas inadequadas.

O levantamento dos fatores de degradação das Áreas de Preservação Permanente e da zona ripária da Microbacia do Ribeirão São João mostrou como sendo os principais os seguintes (Figura 34):

- fogo acidental oriundo das queimadas dos canaviais;

- estradas rurais mal conservadas e localizadas;

- assoreamento das matas paludosas, ribeirinhas e campos úmidos;

- $\quad$ presença de plantas invasoras;

- $\quad$ pastoreio do rebanho devido à falta de cercas protegendo a APP;

- erosão nos barrancos dos leitos do rios;

- depósito clandestino de lixo e

- corte seletivo de espécies com vocação madeireira.

Estes mesmos autores afirmam que a retirada dos fatores de degradação representa uma das principais atividades para a recuperação das formações ciliares ou ripárias.

A restauração de formações ciliares tem maiores possibilidades de sucesso quando está inserida no contexto de bacia hidrográfica, com justificativas nas questões hidrológicas, que acarretam também adequação do uso do solo agrícola do entorno e da própria área a ser restaurada, a preservação da interligação de remanescentes naturais, proteção de nascentes, etc (Rodrigues \& Gandolfi , 2000). 
Impactos causados pela agricultura à Área de Preservação Permanente e à Zona Ripária

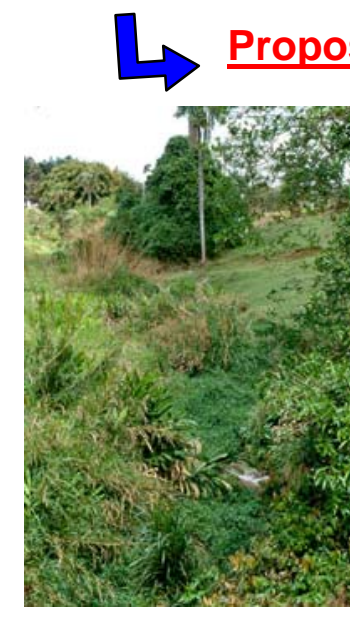

Plantas invasoras
Estrada cortando a zona ripária

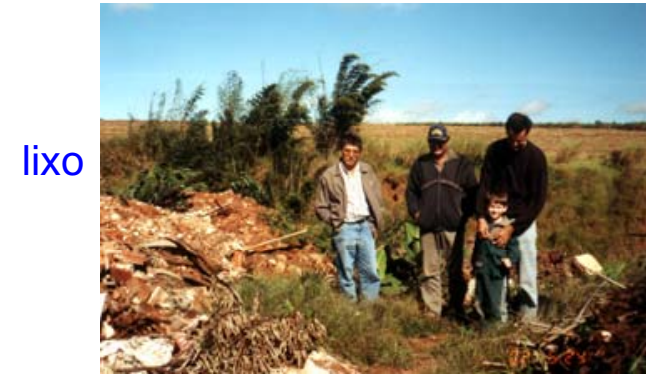

assoreamento

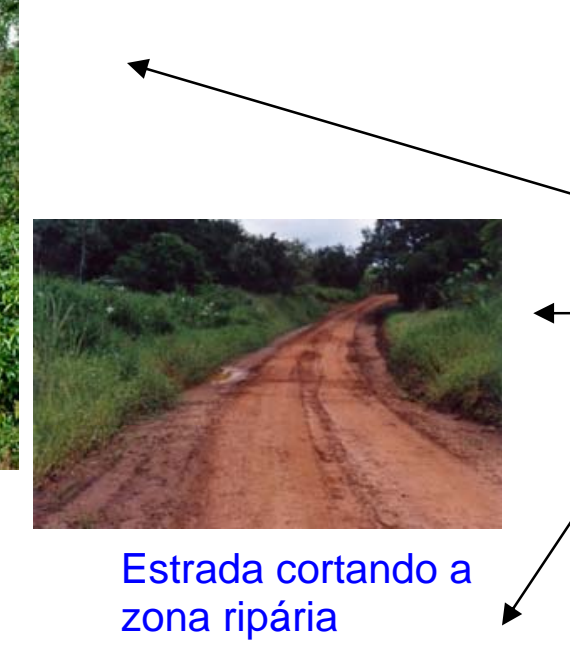

Pastoreio na mata ciliar
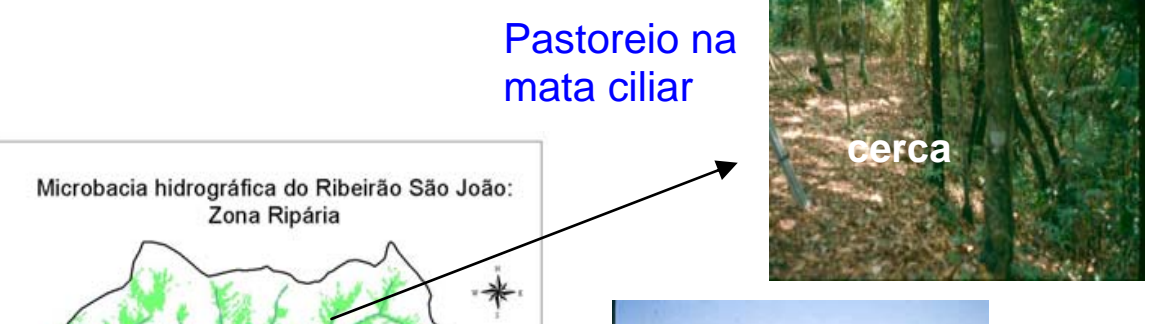

Fogo

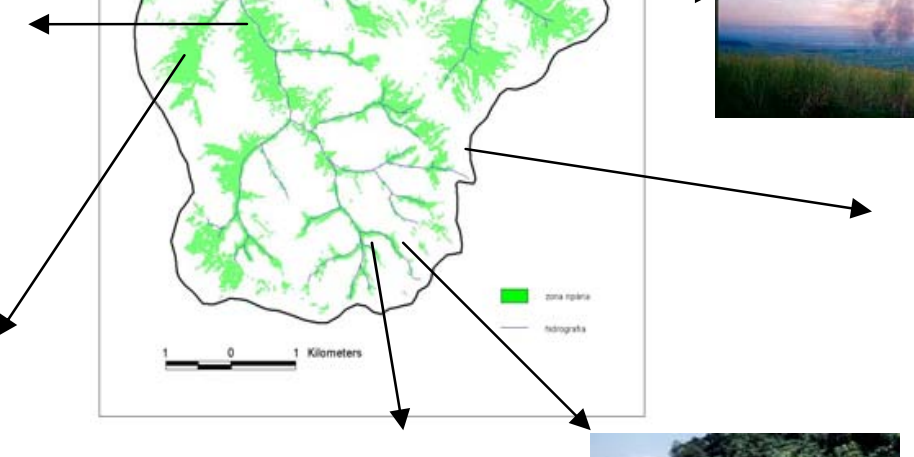

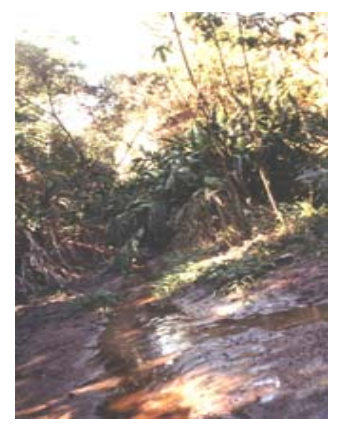
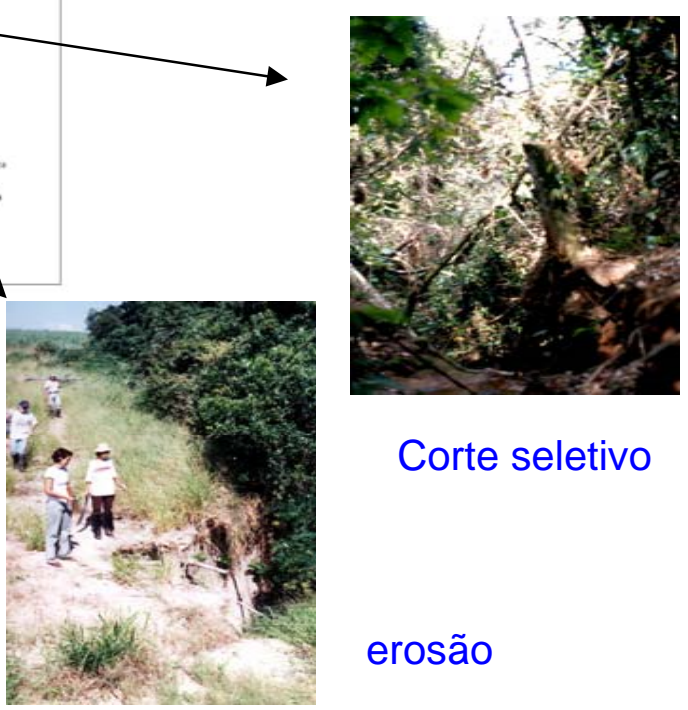

Corte seletivo

erosão

Figura 34 - Detalhes de áreas onde ocorrem impactos causados pela agricultura à mata ciliar e à zona ripária da microbacia do Ribeirão São João (Mineiros do Tietê, SP). Ano: 2004 


\section{- As estradas rurais}

A adequação das estradas rurais deve estar inserida no plano de manejo integrado da microbacia. Na microbacia do Ribeirão São João, as estradas rurais que representam risco de degradação do solo e da zona ripária, causando erosão, atravessando cursos d’ água, destruindo a vegetação, alterando os processos hidrológicos e conseqüentemente a dinâmica das florestas ribeirinhas, devem ser adequadas ou relocadas (Figura 35).

Existe na microbacia uma malha viária de aproximadamente $27 \mathrm{~km}$, que beneficia diretamente 84 pequenos produtores, 37 médios produtores e 40 alunos da zona rural. O Levantamento das estradas rurais realizado pela CATI mostrou que em média $50 \%$ das áreas adjacentes às estradas possuem práticas integradas de uso e manejo do solo, 45 \% da extensão das estradas causam erosão nas áreas adjacentes e a condição de trafegabilidade é regular.

O tráfego mais intenso ocorre de maio à novembro em decorrência da safra de cana de açúcar, com a passagem de veículos pesados tais como caminhões, colheitadeiras, tratores, etc. As estradas MNT 323 (2,1 km), MNT 010 (4,8km), MNT $471(7,1 \mathrm{~km})$ e um trecho da MNT 021 (2 km), grifadas em lilás na Figura 35, estão localizadas na baixa encosta atravessando em muitos pontos cursos d' água e a zona ripária. No levantamento socioeconômico e ambiental os produtores rurais responderam $4 \%$ dos produtores entrevistados consideram que as estradas apresentam problemas o ano todo, 60 \% deles julgam que não são trafegáveis na época das chuvas e 36 \% que são trafegáveis durante o ano todo.

A observação da Figura 35, indicando os pontos em que as estradas atravessam os cursos d' água e a zona ripária e o depoimento de 60 \% dos produtores que acusam o impedimento do tráfego em épocas chuvosas (Quadro 4), juntos fundamentam a necessidade da adequação das estradas para que estes danos ambientais e sociais não ocorram. 


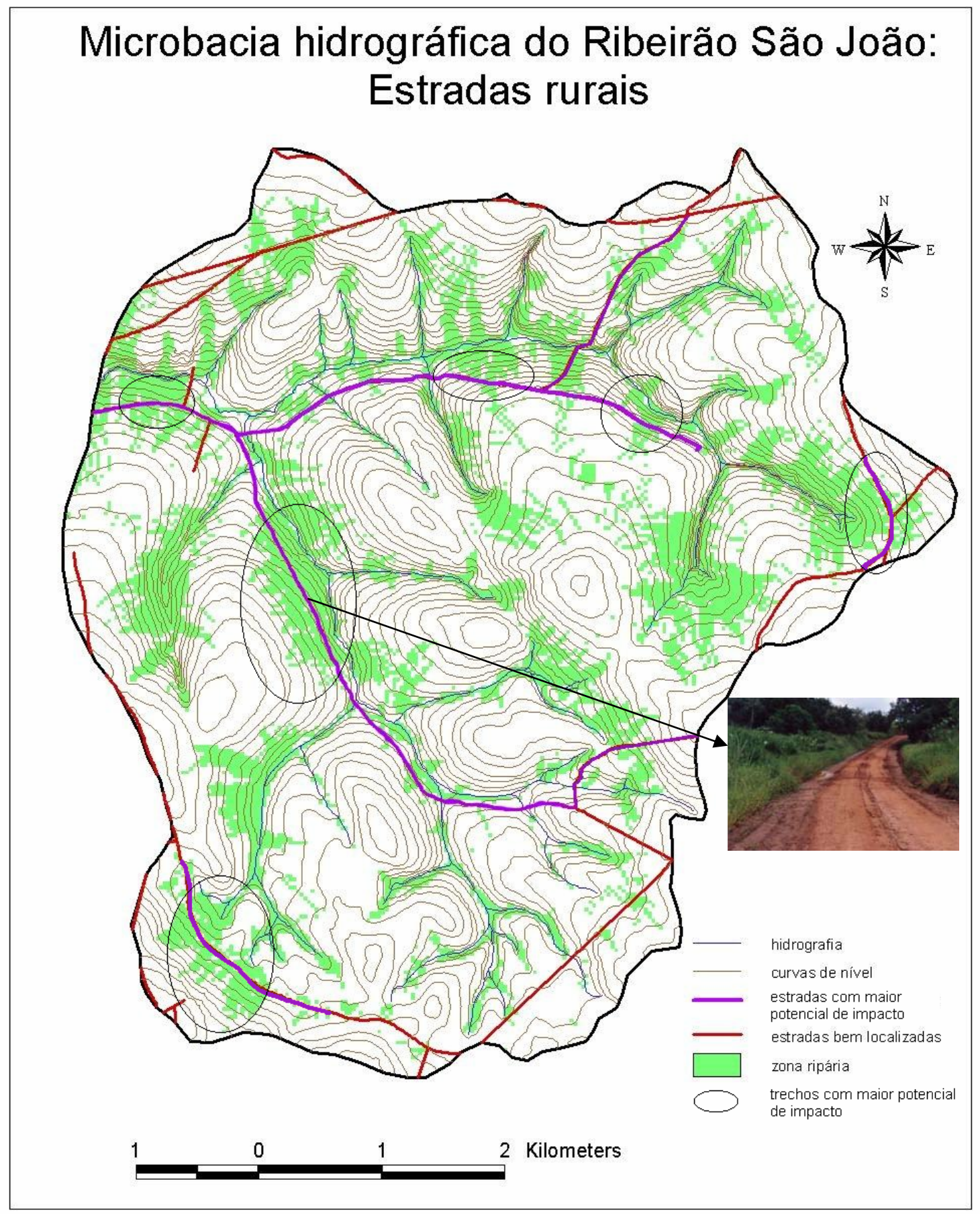

Figura 35 - Carta mostrando as estradas rurais e os trechos com maior potencial de impacto e a zona ripária na microbacia do Ribeirão São João (Mineiros do Tietê, SP). Ano: 2004 
As estradas rurais em uma microbacia devem, sempre que possível, estar localizadas nos divisores d' água, onde a adequada distribuição das águas pluviais atenuam os riscos de erosão e onde não causam impactos à dinâmica da zona ripária.

O manejo inadequado das águas pluviais vindas das estradas rurais causa danos às mesmas e às áreas adjacentes. Entretanto, muitas vezes, são as águas pluviais das áreas agrícolas adjacentes que invadem as estradas causando problemas nos taludes e leitos carroçáveis (Bertolini et al., 1993). A localização das estradas rurais em áreas mais baixas da microbacia, próximas aos cursos d'água, causam danos ambientais decorrentes de alterações provocadas na dinâmica da zona ripária e conseqüentemente das florestas ribeirinhas e da qualidade da água dos rios.

A vegetação que ocupa a zona ripária apresenta uma grande variação de estrutura, composição e distribuição espacial, devido às variações determinadas diretamente pelo comportamento hidrológico característico do local (Lima \& Zakia, 2000). Desta forma, alterações na dinâmica hídrica da zona ripária, provocada pela passagem de uma estrada, causam danos à vegetação adaptada aquela condição.

A adequação das estradas rurais é realizada através de abatimento de taludes, obras de drenagem (terraceamento, pontes, bueiros, etc) e revestimento primário, além da implantação, onde não houver, de um manejo integrado do solo e da água em propriedades rurais localizadas nas áreas adjacentes.

Em alguns casos, a relocação de trechos das estradas rurais ou a mudança de seu traçado é a medida mais adequada que permiti a eliminação dos problemas de degradação dos recursos naturais, em especial da zona ripária que se constitui nas áreas mais sensíveis e dinâmicas da microbacia. Entretanto a implementação de travessias adequadas (bueiros, pontes, etc), que impessam a degradação destas áreas, pode representar uma decissão menos onerosa, mais factível e prática para o acesso às propriedades rurais e a racionalização do transporte da safra agrícola, em microbacias com uso agrícola diversificado e com complexa distribuição fundiária.

Segundo o Programa Estadual de Microbacias Hidrográficas (1997), para a elaboração de projetos técnicos de estradas rurais é importante: 
- a racionalização de recursos (aproveitamento de materiais locais, etc),

- evitar desgastes ao meio ambiente, através de maior proteção do solo, mínima movimentação de terra, integração das práticas conservacionistas da propriedade, não derrubada de árvores nativas, evitar abertura de novas estradas, etc.

- buscar facilidade para a manutenção e

- buscar alternativas que resultem em menores perdas de área explorada e em benefícios aos produtores.

Blin \& Kilgore (2001) sugerem estratégias de manejo da zona ripária, principalmente relacionadas às estradas rurais:

- identificar os limites da zona ripária, inclusive sua dinâmica temporal;

- minimizar as travessias dos cursos d' água por estradas e carreadores;

- definir o ponto de travessia de curso d’ água de maneira a minimizar os impactos ambientais;

- definir o traçado das estradas e carreadores sem passar pela zona ripária;

- definir áreas específicas de manutenção e armazenamento de máquinas e equipamentos fora da zona ripária e

- na preparação para a colheita, não descartar, na zona ripária, os resíduos acumulados. 


\subsection{Monitoramento sócio-ambiental da microbacia do Ribeirão São João}

Diante do proposto pelo presente trabalho, a inclusão do conceito de zona ripária na determinação da adequação do uso da terra e dos riscos de degradação ambiental para a busca da sustentabilidade no manejo integrado de microbacias hidrográficas, é imprescindível a apresentação de uma discussão sobre o monitoramento socioeconômico e ambiental, que por definição é parte intrínseca do processo de desenvolvimento sustentável.

Entretanto, não é a intenção apresentar um programa completo para o monitoramento de microbacias, com a descrição detalhada de todos os indicadores e da metodologia relacionada a cada um deles. Todavia, com base no estudo de caso da microbacia do Ribeirão São João e considerando a inclusão da zona ripária no planejamento integrado de microbacias, a intenção deste ítem, além de se constituir em uma base conceitual sobre monitoramento e indicadores, é sugerir alguns indicadores importantes relacionados ao enfoque ecossistêmico desta microbacia estudada, com fundamentação em revisão de literatura. É preciso esclarecer que até o término deste trabalho de pesquisa não foi implementado integralmente um programa de monitoramento socioeconômico e ambiental nesta microbacia hidrográfica.

Uma proposta para o desenvolvimento de um programa de monitoramento no contexto desta pesquisa deve não apenas oferecer uma ferramenta de reorientação das práticas de manejo previstas no planejamento, mas também possibilitar uma aferição dos resultados e impactos das ações do Programa Estadual de Microbacias Hidrográficas, assim como apresentar uma sugestão de indicadores para o monitoramento de outras microbacias trabalhadas tanto por órgãos públicos, como por privados, apoiar os órgãos fiscalizadores e os de gerenciamento dos recursos hídricos, como os comitês de bacias hidrográficas e, finalmente, oferecer à sociedade respostas sobre a maneira como os recursos naturais vêm sendo manejados.

Vários autores, com base em seus estudos sobre monitoramento em microbacias,

fazem importantes considerações sobre os indicadores e os programas de monitoramento. 
Desta forma, com base no conceito de escalas de sustentabilidade e suas respectivas implicações em termos de indicadores de monitoramento e levando em conta as condições atuais da microbacia do Ribeirão São João, de acordo com o cenário proposto ou cenário hidrológico (com inclusão da zona ripária), uma sugestão de monitoramento sócio-ambiental deve levar em conta pelo menos os seguintes aspectos:

\subsubsection{Monitoramento da água}

O monitoramento da água na microbacia constitui importante subsídio para avaliação das práticas de manejo dos recursos naturais para a produção agrícola. É importante também sob a ótica do manejo e proteção da zona ripária, já que as funções por ela desempenhadas estão intimamente relacionadas à qualidade e quantidade das águas dos rios, ribeirões, nascentes, águas subsuperficiais e subterrâneas.

Câmara (1999), após avaliar a qualidade da água em uma microbacia experimental, constatou que os parâmetros físicos da água como a turbidez, a cor, a condutividade elétrica e os sedimentos em suspensão apresentam-se como bons indicadores. A turbidez e a cor estão relacionados à presença de material em suspensão na água como argilas, detritos orgânicos que impedem a passagem de luz, sendo largamente utilizados para análises de perda de solo.

Segundo Arcova (1996) a condutividade elétrica pode ser usada para detectar as variações nas características qualitativas da água, pois está diretamente relacionada à concentração de íons, prestando-se nesse caso para inferir sobre a perda de nutrientes.

Para Chapman et al.(1992), dentre as variáveis para avaliação da qualidade da água com relação às atividades agrícolas estão: sólidos em suspensão, oxigênio dissolvido, compostos nitrogenados, fósforo, demanda bioquímica de oxigênio e pesticidas, dentre outras.

Cranston et al. (1996) recomendam os macroinvertebrados como indicadores biológicos da qualidade da água da microbacia. Os macroinvertebrados aquáticos usados em monitoramento compreendem os insetos em sua fase imatura. Os indicadores biológicos confiáveis são aqueles que possuem uma tolerância estreita e específica aos 
impactos ambientais. Os seres vivos podem ser utilizados para descrever e classificar os ecossistemas, para indicar os efeitos das atividades antrópicas e para monitorar a recuperação do ecossistema.

A característica de múltiplas escalas implícitas no conceito de agricultura sustentável é, sem dúvida, importante para esta análise conceitual dos indicadores, conforme pode ser observado no Quadro 27. Assim, é imprescindível haver indicadores apropriados para cada caso.

Com base nesta discussão, os indicadores essenciais para o monitoramento da água na microbacia do Ribeirão São João, levando em consideração a proposta contida nos cenários hidrológicos, são os seguintes: o balanço hídrico, a vazão, a concentração de nitrogênio e fósforo na água, a turbidez, a condutividade elétrica, a cor, os sólidos em suspensão, o oxigênio dissolvido e os macroinvertebrados aquáticos.

Estes indicadores podem ser úteis para avaliar o desempenho de algumas das principais funções do ecossistema ripário, isto é, a manutenção do regime de vazão da microbacia, o controle do aporte de sedimentos aos cursos d' água (Figura 36) e a retenção, pelo sistema radicular da mata ripária, de nutrientes liberados das áreas agrícolas do entorno que chegam aos rios através de seu transporte em solução no escoamento subsuperficial (efeito tampão). Estes indicadores refletem também as condições e as tendências do meio resultantes do uso e do manejo agrícola na microbacia, devido a forte relação entre o uso do solo e os processos hidrológicos.

Sob a ótica da agricultura sustentável é fundamental o uso de indicadores hidrológicos para o monitoramento da microbacia, correlacionando as causas e os efeitos entre as atividades agrícolas e a degradação ambiental e avaliando o desempenho das funções do ecossistema ripário.

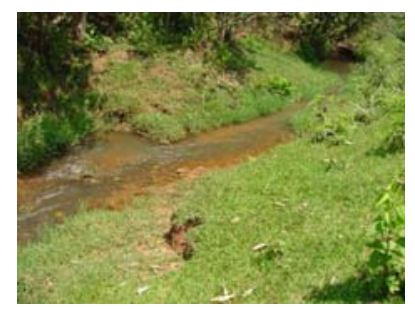

Figura 36 - Águas turvas do Ribeirão São João (Mineiros do Tietê, SP) (indicador visual) 


\begin{tabular}{|c|c|c|c|}
\hline Escala & Impacto ambiental & Possíveis causas & Indicadores \\
\hline Macro & $\begin{array}{l}\text { - uso conflitivo da } \\
\text { água } \\
\text { - desfiguração da } \\
\text { paisagem }\end{array}$ & $\begin{array}{l}\text {-reflorestamento } \\
\text {-substituição de florestas naturais } \\
\text { por agricultura } \\
\text { - desmatamento, reflorestamento }\end{array}$ & $\begin{array}{l}\text {-balanço hídrico } \\
\text {-zoneamento ecológico } \\
\text { - representatividade da área } \\
\text { em termos de ecossistema }\end{array}$ \\
\hline Meso & $\begin{array}{l}\text { - alteração do regime } \\
\text { de vazão } \\
\text { - eutrofização } \\
\text { - assoreamento dos } \\
\text { cursos d’ água } \\
\text { - perdas de nutrientes } \\
\text { por lixiviação } \\
\text { - material orgânico } \\
\text { - tóxicos }\end{array}$ & $\begin{array}{l}\text { - estradas inadequadas } \\
\text {-desproteção da zona ripária } \\
\text { - destruição da camada orgânica do } \\
\text { solo } \\
\text { - compactação do solo } \\
\text { - erosão } \\
\text { - desmatamento e agricultura } \\
\text { intensiva } \\
\text { - adub. inadequada, ausência de } \\
\text { mata ciliar, degrad. da zona ripária } \\
\text { - erosão } \\
\text { - decomposição de matéria } \\
\text { orgânica e resíduos na água } \\
\text { - solo descoberto e erosão }\end{array}$ & $\begin{array}{l}\text {-desenho, densid. e declivid. } \\
\text { - extensão e condição da } \\
\text { mata ciliar } \\
\text { - taxa de mineralização do } \\
\text { nitrogênio, queima de } \\
\text { resíduos } \\
\text { - infiltração } \\
\text { - práticas de conserv. do } \\
\text { solo } \\
\text { - vazão } \\
\text { - concentração de N e P na } \\
\text { água } \\
\text { - turbidez }\end{array}$ \\
\hline Micr & $\begin{array}{l}\text { - degradação da mata } \\
\text { ciliar }^{2}\end{array}$ & $\begin{array}{l}\text { - cultivo intensivo, monocultura, } \\
\text { baixa agrobiodiversidade, baixa } \\
\text { fertilidade química } \\
\text { - práticas agrícolas inadequadas } \\
\text { (descarga de sedimentos e águas } \\
\text { superficiais, fogo, extrativismo) }\end{array}$ & $\begin{array}{l}\text { - parâmetros vegetacionais } \\
\text { (diversidade, riqueza, } \\
\text { fisionomia vegetal, etc) }\end{array}$ \\
\hline
\end{tabular}

${ }^{1}$ A partir de Altieri (2002), ${ }^{2}$ A partir de Rodrigues \& Galdolfi (2000)

Quadro 27 - Indicadores de sustentabilidade em diferentes escalas da atividade agrícola (a partir de Lima, 1999) 


\subsubsection{Monitoramento do solo}

A qualidade do solo está intensamente relacionada à saúde da microbacia, aos aspectos hidrológicos, às práticas de manejo e ao rendimento econômico da atividade agrícola. Assim sendo, é um fator importante a se considerar para a busca da sustentabilidade, tendo em vista, inclusive a interação e a inter-dependência que ocorrem entre os sistemas ecológicos (água, solo, flora, fauna) em uma microbacia.

Fitzpatrick (1996), em um trabalho sobre os indicadores morfológicos de saúde do solo, afirma que é recomendado que informações morfológicas qualitativas façam parte dos programas de monitoramento, pois podem ser usadas tanto por produtores rurais como por cientistas pra reconhecer no campo a degradação do solo causada por: erosão hídrica (indicada pela presença de sulcos, rochas na superfície, exposição de raízes e superfície desigual do solo) (Figura 37), erosão eólica (indicada por marcas de ondulação no solo e assoreamento nos caules das plantas), drenagem deficiente e compactação do solo (indicadas por empoçamento da água e crescimento desigual das plantas), salinização (indicada pela presença de crostas salinas e ingresso de plantas tolerantes à salinização) e perda de matéria orgânica, redução da agregação, baixa condutividade hidráulica (encrostamento do solo e selamento dos poros das camadas superficiais). Os atributos morfológicos de saúde do solo podem ser estimados suficientemente pela calibração das observações qualitativas em comparação aos valores mensurados (Figura 38).

As observações visuais dos indicadores de saúde da microbacia têm sido muito utilizadas nos procedimentos de pesquisa. 


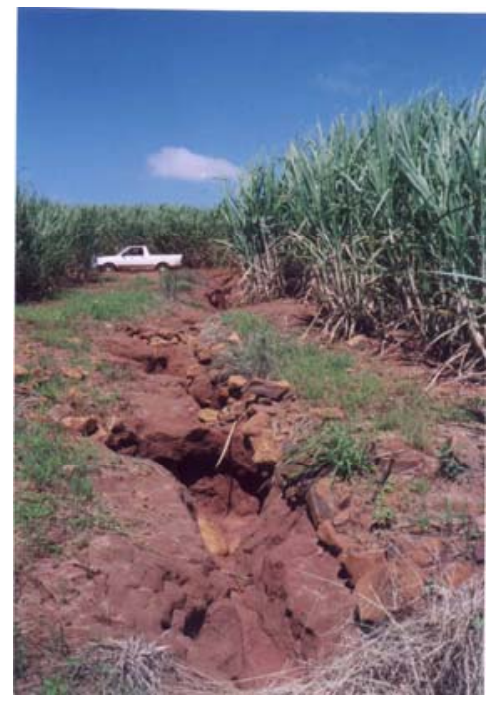

Figura 37 - Degradação do solo com afloramento de rochas causada por erosão hídrica na microbacia do Ribeirão São João (Mineiros do Tietê, SP)

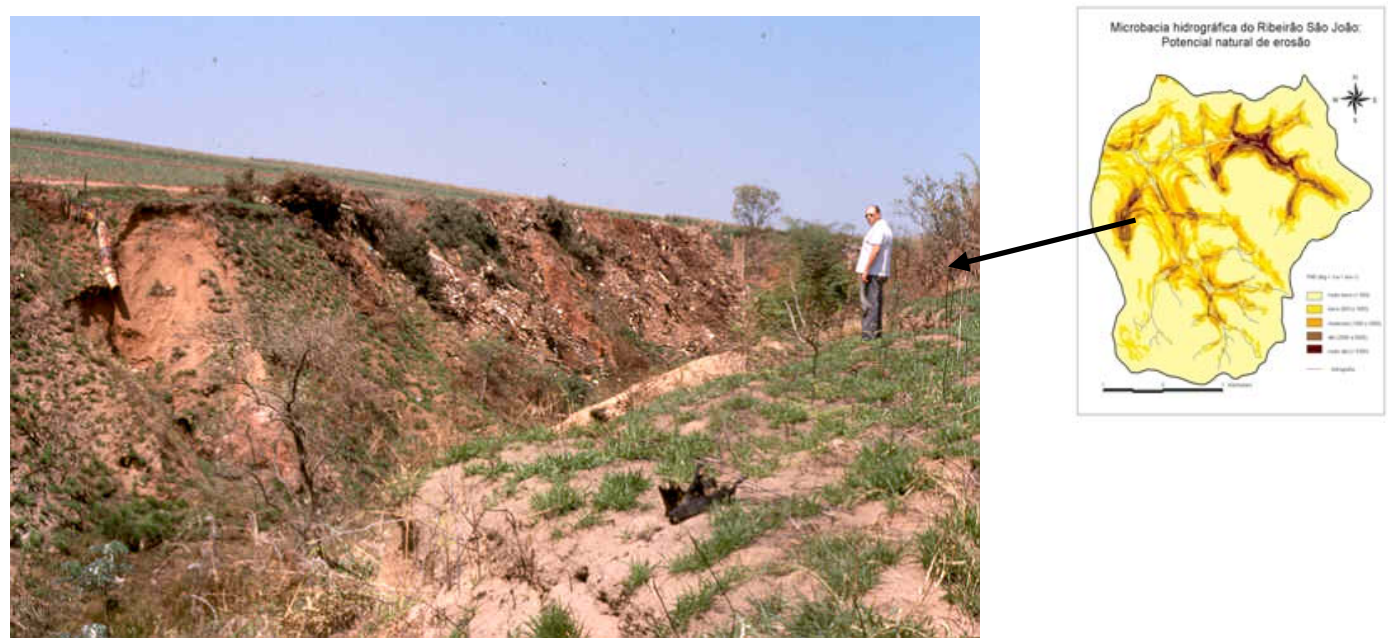

Figura 38 - Observações visuais de degradação do solo na microbacia do Ribeirão São João (Mineiros do Tietê, SP) em comparação aos valores mensurados 
Os indicadores físicos de saúde do solo proposto por Cass et al. (1996) são: taxa de infiltração de água no solo, agregação e dispersão do solo e resistência do solo à penetração. Esses indicadores devem descrever a qualidade física, a estabilidade da estrutura do solo e o grau de degradação, através de mensurações simples e indicações visuais como, por exemplo, a permanência de água na superfície do solo por longos períodos.

Merry (1996) propõe para indicadores químicos de saúde do solo o $\mathbf{p H}$, a condutividade elétrica e fertilidade química do solo.

As características químicas do solo podem ser agrupadas em classes:

1- aquelas que indicam os processos e comportamento do solo, por exemplo: $\mathrm{pH}$

2- aquelas que indicam a capacidade de resistir a mudanças (tamponamento), ou de reter nutrientes ("Filtro"), por exemplo: capacidade de trocas de cátions e ânions, quantidade e tipo de argila $(\mathrm{pH})$.

3- aquelas que derivam das exigências das plantas e dos nutrientes químicos do solo, por exemplo: N, P K, cátions $(\mathrm{pH})$.

4- aquelas que indicam contaminação ou poluição, por exemplo: sódio trocável $(\mathrm{pH})$, sais (condutividade elétrica).

O pH do solo é o mais simples e informativo indicador químico da saúde do solo. As análises químicas do solo são muito valiosas para dimensionar os indicadores químicos, pois são um método padronizado de mensuração, de fácil acesso, a probabilidade de erro é baixa e os valores numéricos obtidos são facilmente mapeados (Merry,1996).

Para Dumanski \& Pieri (2000) a qualidade do solo reflete e é mensurada através das condições que o fazem ser considerado um "corpo vivo”. As evidências comprovam que as características físicas, químicas e os dados taxonômicos, não são, por si só, úteis para descrever a qualidade do solo. Um importante indicador-substituto pode ser adquirido através dos dados sobre matéria orgânica, particularmente da concentração de carbono microbiano. A matéria orgânica do solo é o melhor indicador-substituto para a saúde do solo, pois é responsável pela manutenção de sua estrutura, dos nutrientes 
e do estoque de carbono orgânico e da atividade microbiana. Este indicador deve ser relacionado com a intensidade do uso do solo, com a agro-diversidade e com a cobertura do solo.

A Figura 39 adaptada por Chaer (2001) a partir de Larson \& Pierce (1994), correlacionando o que foi discutido anteriormente sobre os indicadores da saúde do solo, mostra o relacionamento das suas funções com os atributos de qualidade do solo e estes com os indicadores, tendo em vista a produção agrícola. A capacidade do solo de desempenhar todas as suas funções está direta ou indiretamente ligada, e em graus de importância diferentes, á qualidade dos atributos, resumidos em suas qualidades físicas, químicas e biológicas. Os indicadores de qualidade do solo, assim como da água e de outros fatores, são substitutos mensuráveis dos atributos, já que estes não podem ser medidos diretamente.

Chaer (2001) constatou em seu trabalho que os indicadores microbiológicos (como por exemplo, o quociente metabólico) se mostraram mais sensíveis que os físicos e químicos para avaliar mudanças na qualidade do solo decorrentes das técnicas de preparo do solo.

Leonardo (2003) concluiu em sua pesquisa sobre indicadores de qualidade do solo que a densidade aparente e o quociente metabólico foram os que se mostraram mais eficientes.

Tendo como fundamentação as propostas destes autores, o monitoramento do solo da microbacia do Ribeirão São João, deve incluir, no mínimo, os seguintes indicadores: os indicadores visuais de degradação do solo, já citados, devido à facilidade de sua avaliação, podendo ser usados tanto por produtores rurais (incentivando sua participação neste processo), como por pesquisador; a taxa de infiltração de água no solo, a agregação e a dispersão do solo, a resistência do solo à penetração, a densidade aparente e a matéria orgânica, indicadores físicos e químicos do solo intimamente relacionados aos processos hidrológicos da microbacia; o pH, pela sua facilidade de acesso e o quociente metabólico, por ser um dos mais sensíveis e eficientes indicadores de qualidade do solo. 


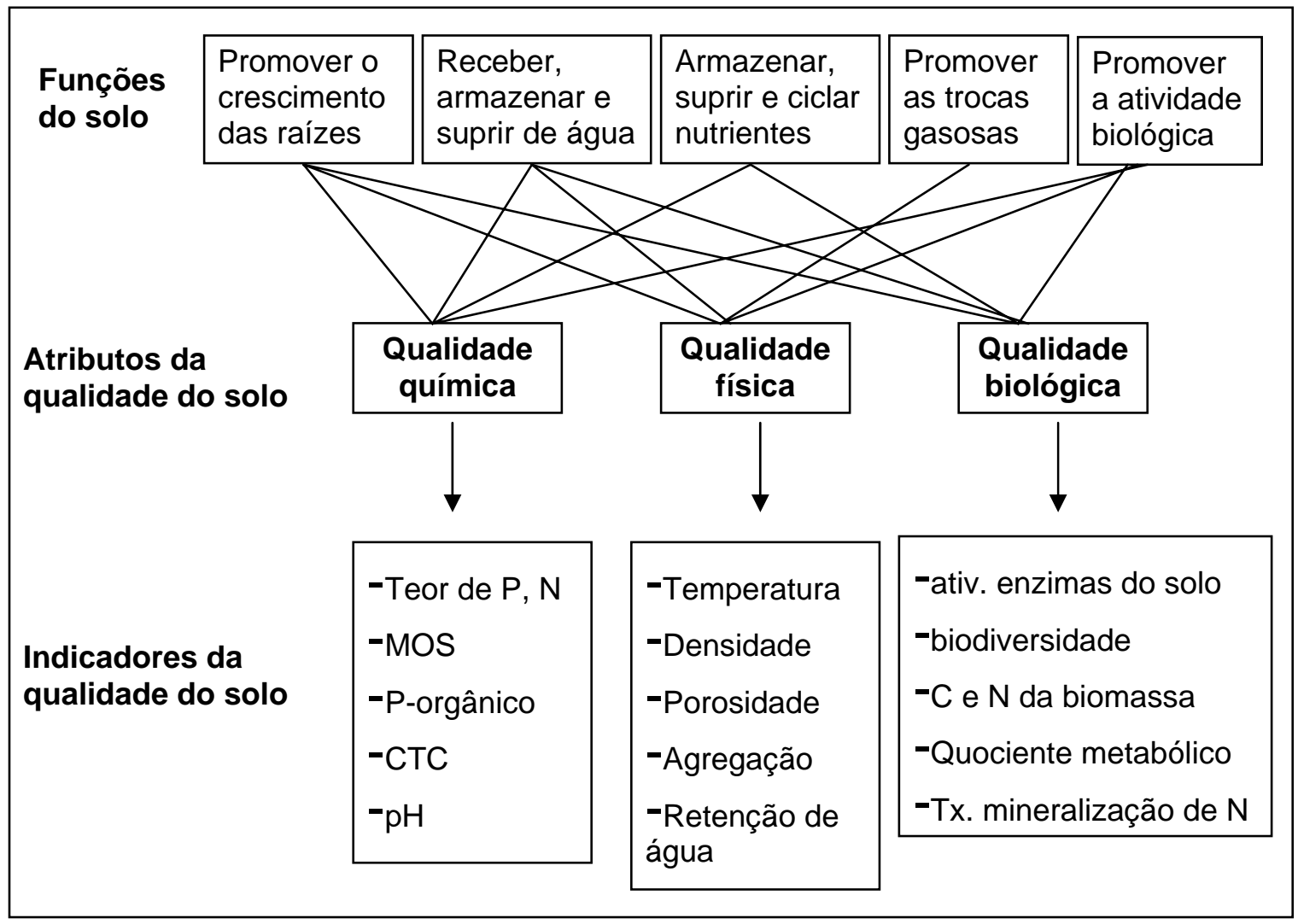

Figura 39 - Funções do solo, atributos a elas relacionados e indicadores de qualidade do solo para a produção vegetal (Chaer (2001),a partir de Larson \& Pierce (1994)

Os indicadores de saúde da microbacia devem ser analisados em conjunto, considerando as interações que ocorrem dentro dos limites da microbacia, comprovadas, por exemplo, pela influência da estrutura do solo na infiltração da água das chuvas na terra, acarretando regularidade no regime de vazão e favorecendo o escoamento subsuperficial ou causando a predominância do escoamento superficial e conseqüentemente a erosão.

Os cenários que incluem a análise da zona ripária na adequação do uso do solo e nas considerações sobre as áreas de riscos de erosão propõem justamente uma forma de planejar e monitorar que preveja o envolvimento e a integração entre os processos hidrológicos e o solo na microbacia, a vegetação e os aspectos socioeconômicos. 


\subsubsection{Monitoramento da integridade da paisagem e da biodiversidade agroambiental}

\section{Integridade da paisagem}

Assim como os atributos de qualidade de água e do solo, os relacionados à integridade da paisagem também possibilitam avaliar de maneira integrada as conseqüências das práticas de manejo agrícola e da degradação das matas ripárias na escala da microbacia.

Jones et al., (1996) separou os indicadores da integridade da paisagem em grupos, sendo que alguns estão descritos a seguir:

- Indicadores da composição e do padrão da cobertura do solo: a dominância de um ou vários tipos de cobertura vegetal (por exemplo, pastagem, culturas, floresta nativa, etc.) e sua localização influenciam o comportamento da microbacia. Os indicadores recomendados neste grupo são:

1. tipo de cobertura do solo dominante na área (como por exemplo a porcentagem de cobertura arbórea e de ervas invasoras, sendo estes sugeridos como indicadores chave), que em paisagens agrícolas está relacionada á qualidade da água e aos processos erosivos na escala da microbacia, refletindo as pressões do uso da terra,

2. conectividade e grau de fragmentação dos tipos de cobertura do solo, determinando a extensão e grandeza dos impactos (tais como fogo, doenças, inundações, etc.), a diversidade e a sustentabilidade de espécies de plantas e animais,

3. complexidade das formas de cobertura do solo que mostram o grau da alterações antrópicas do meio ambiente e dos impactos que podem ocorrer nos processos ecológicos, já que a natureza tende a formar ambientes complexos e o homem ambientes simples,

4. tamanho das áreas de cada tipo de cobertura do solo para a avaliação da possibilidade de uma área suportar uma dada espécie animal ou vegetal, 
5. a porcentagem de áreas agrícolas localizadas em encostas com declives maiores que $5 \%$ indicando o potencial de perda de solo e escoamento superficial e uma propriedade agrícola,

6. a quantidade de um tipo de cobertura do solo em estado protegido e a porcentagem de cada tipo de cobertura do solo em diferentes escalas, podem indicar o risco de perda de determinado tipo de cobertura que desempenhe importante função ( por exemplo, floresta ripária).

- Indicadores da extensão e distribuição da zona ripária: as condições da zona ripária, alterações na porcentagem de sua largura e extensão ao longo do curso d' água e a sua conectividade são importantes indicadores do risco de declínio da qualidade da água, pois determinam as perdas de solo, transporte de sedimentos e contaminantes nas escalas da propriedade agrícola, microbacia e bacia hidrográfica. Podem ser avaliados pelas observações de campo, fotografias aéreas e Sistemas de Informações Geográficas (SIG).

- Indicadores do grau de limitações biofísicas: a posição das propriedades agrícolas e da sub-bacia na microbacia, com relação aos recursos hídricos, por exemplo, podem representar restrições e impactos na microbacia.

Na microbacia do Ribeirão São João, vem sendo estimulada a regeneração natural da vegetação em torno das nascentes do Córrego do Borralho (Figura 40), devido ao interesse da prefeitura do município de Jaú, proprietária da área, na produção hídrica, pois é onde ocorre a captação de água para a população daquele município.

As alterações no padrão e na área da mata ripária podem servir para avaliar a diminuição ou aumento de sua capacidade de filtragem de materiais e de controlar o assoreamento em uma microbacia e conseqüentemente alterações na qualidade e quantidade da água. Da mesma forma, mudanças no tipo de cobertura do solo podem indicar o risco de erosão e de perda de solo. 

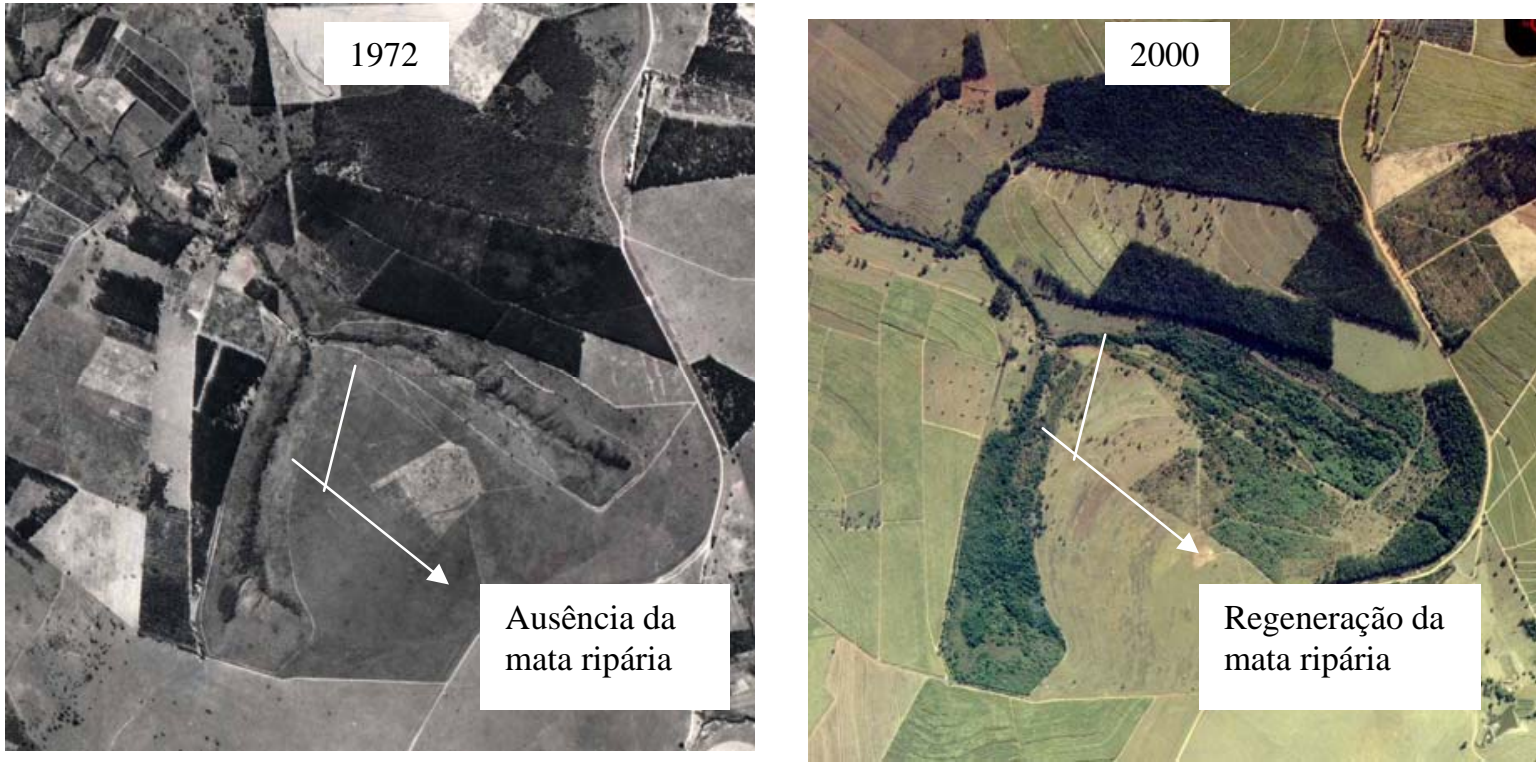

Figura 40 - Alteração, após 28 anos, no padrão e na área da zona ripária em nascentes do Córrego do Borralho (microbacia do Ribeirão São João, Mineiros do Tietê, SP), onde se faz a captação de água para abastecimento urbano de Jaú

Ainda segundo Jones et al., (1996), é necessário estabelecer um perfil de indicadores, qualitativos e quantitativos, para microbacias em condições boas, regulares e ruins considerando os valores ambientais. Estes perfis poderiam apoiar as decisões de identificação e priorização das opções do manejo ambiental para reduzir os riscos de perda dos bens e serviços ecológicos. Serviriam também para ajudar os grupos locais, como o de agricultores, a entender as condições da paisagem na qual estão inseridos e a estabelecer um plano de manejo, a nível local, mais eficiente.

Através do uso de fotografias aéreas, Sistemas de Informações Geográficas e observações de campo, a análise de indicadores da composição e do padrão da cobertura do solo, da posição das propriedades agrícolas com relação aos recursos hídricos e, em especial no caso do presente trabalho, da extensão e distribuição da zona ripária, podem refletir as condições e riscos ambientais em várias escalas, agroecossistema, microbacia, região, e possibilitam estimar a eficácia do manejo ecossistêmico e das ações de restauração, incluindo os benefícios que um estudo sobre 
conectividade de fragmentos florestais, por exemplo, para a facilitação da recuperação da vegetação nativa, da sobrevivência da fauna regional, etc.

Nestas avaliações os indicadores visuais também se mostram eficientes tanto para a comunidade local como para os planejadores beneficiando inclusive as atividades de diagnóstico e planejamento participativos.

\section{Biodiversidade agroambiental}

A biodiversidade é uma característica importante no que se refere à integridade e funcionamento de ecossistemas naturais ou agroecossistemas.

A diversidade biológica junto com a intensidade e a longevidade das perturbações determina a resiliência dos ecossistemas, isto é, a sua capacidade de se regenerar após alguma degradação, seja ela natural ou antrópica, estando, desta maneira, relacionada à saúde do ecossistema (Aronson et al., 1993).

Em agroecossistemas, a diversidade pode estar na forma de um arranjo específico de cultivos de uma área, de como as diferentes áreas são organizadas (microescalas) e de como são distribuídas na paisagem agrícola de uma região (macroescala). Na maioria dos agroecossistemas, a perturbação é muito mais freqüente, regular e intensa do que em ecossistemas naturais, por isso são considerados instáveis. A estabilidade deve ser compreendida como a resistência do sistema aos impactos e sua resiliência em resposta a ele (Gliessman, 2001).

Dumanski \& Pieri (2000) propõem os indicadores apresentados do Quadro 28 para agro-biodiversidade. 


\begin{tabular}{|c|c|}
\hline Indicadores & Representantes \\
\hline Perda de habitat natural & $\begin{array}{c}\text { Ocupação pelos sistemas de produção } \\
\text { agrícolas }\end{array}$ \\
\hline Fragmentação de habitat & $\begin{array}{c}\text { Ocupação agrícola de maneira } \\
\text { desordenada }\end{array}$ \\
\hline Perda de espécies mesmo em habitats & Poluição, sedimentação, colheita \\
intactos & constante,etc \\
\hline Declínio da biodiversidade de espécies & Adoção de monoculturas, redução de \\
cultivadas em propriedades rurais & cultivos mistos \\
\hline Declínio da diversidade dentro de espécies & $\begin{array}{c}\text { Adoção de novas variedades, expansão dos } \\
\text { direitos de propriedade intelectural }\end{array}$ \\
\hline
\end{tabular}

Quadro 28 - Indicadores de agro-biodiversidade propostos por Dumanski \& Pieri (2000)

Estes autores comentam que sistemas agrícolas mistos, com integração da agricultura e pecuária ou aqueles envolvendo agrofloresta, possuem maior diversidade genética.

Os agroecossistemas sustentáveis podem ser aqueles com algum tipo de padrão de mosaico em sua estrutura e desenvolvimento (envolvendo espécies anuais, perenes, arbustos, árvores e animais) ou aqueles onde ocorrem diversos estágios de desenvolvimento ao mesmo tempo, como resultado do manejo. Esses sistemas podem incorporar cultivo mínimo (para induzir que um subsistema de solo mais maduro se desenvolva), cultivo em faixas, cultivos consorciados, rotações de culturas, cultura de cobertura (Gliessman, 2001), manutenção das matas ciliares e reservas legais (Figura 41). 


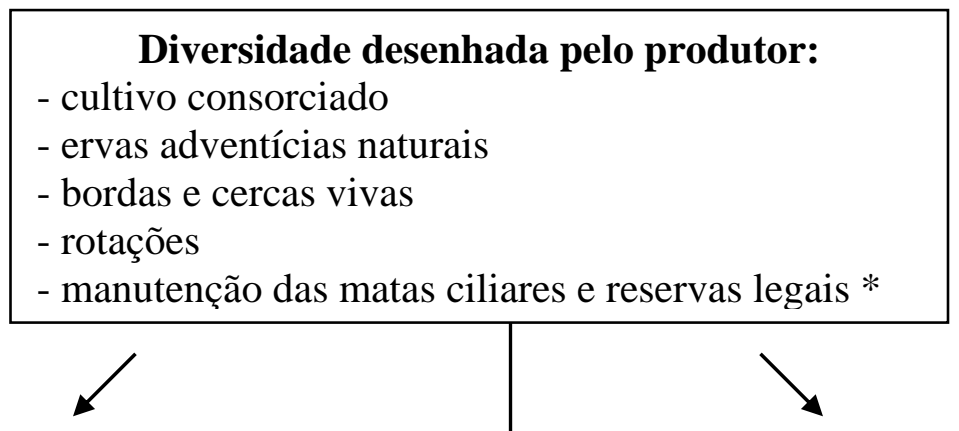

\section{Diversidade biótica aumentada:}

- predadores naturais de herbívoros

- organismos benéficos do solo

- ervas adventícias alelopáticas

- fixadores de nitrogênio

- corredores para movimento da fauna e dispersão de sementes *
Melhoria das condições abióticas:

- maior disponibilidade de

nutrientes

- diferenciação de micro habitats

- aumento da matéria orgânica do solo

- melhoria da estrutura do solo

- melhoria da qualidade dos recursos hídricos *

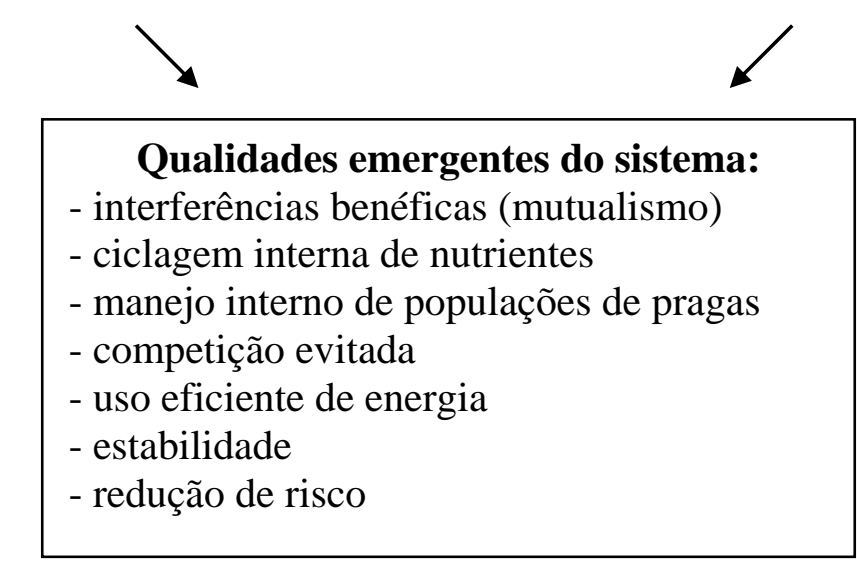

* a partir de Lima (2000)

Figura 41- Dinâmica de agroecossistemas diversificados (Gliessman, 2001)

Dentro da microbacia, os fragmentos naturais remanescentes ou as áreas restauradas também devem ser monitorados, devido sua importância para a saúde da microbacia, como já visto, sendo a diversidade biológica um dos promissores indicadores devido sua íntima relação com a resiliência do sistema. Neste contexto, as 
análises dos indicadores devem ser balizadas pelos preceitos do paradigma contemporâneo da ecologia.

Um conjunto de indicadores de monitoramento, tanto de áreas naturais, como de áreas de restauração florestal, pode ser formado pelos seguintes indicadores: diversidade biológica e equabilidade, acúmulo, fluxo e ciclagem de nutrientes e de propágulos no solo e na serrapilheira, micro e mesofauna de solo, presença e estrutura de grupos faunísticos, etc (Rodrigues, R.R., 2004 - comunicação pessoal).

Os indicadores propostos nesta discussão por Gliessman (2001), Dumanski \& Pieri (2000) e Rodrigues (2004 - comunicação pessoal), em especial a diversidade biológica, tanto em áreas agrícolas quanto em fragmentos de vegetação nativa ou em áreas restauradas de formações ciliares, têm papel fundamental na manutenção do funcionamento dos ecossistemas e conseqüentemente na saúde da microbacia.

\subsubsection{Monitoramento socioeconômico}

A produtividade e a qualidade da produção constituem o principal interesse dos agricultores, pois são os componentes que se relacionam diretamente com o rendimento de suas terras e conseqüentemente representam, assim também como outros componentes, a qualidade de vida da comunidade rural.

Para Gliessman (2001) se a preocupação é a manutenção, a longo prazo, da produtividade dos sistemas agrícolas, é fundamental distinguir entre os que se mantêm temporariamente produtivos devido à utilização intensiva de insumos e aqueles que podem permanecer produtivos indefinidamente, pois neles são mantidas ou favorecidas as bases ecológicas da produtividade do sistema. Um agroecossistema que futuramente se tornará improdutivo fornece indicações de que sua base ecológica está sendo destruída, como por exemplo, ocorrência de erosão das camadas superficiais do solo e declínio da diversidade da biota do solo. É difícil, porém, distinguir na prática os sistemas que estão degradando suas bases e aqueles que não estão. A sustentabilidade é determinada por uma multiplicidade de parâmetros ecológicos, todos em interação, considerá-los isoladamente ou depender somente de alguns, pode ser enganador. Além 
disso, alguns parâmetros são mais críticos do que outros e ganhos em uma área pode compensar algumas perdas em outra. O desafio é entender como os parâmetros interagem e determinar sua importância relativa.

Este autor sugere o índice de produtividade para agroecossistemas como um instrumento que pode ser usado como indicador de sustentabilidade, se for adotada a idéia de que existe uma correlação positiva entre o retorno de biomassa a um agroecossistema e sua capacidade de produzir biomassa para ser colhida.

Índice de Produtividade (IP) = $\underline{\text { Biomassa total acumulada no sistema }}$

Produtividade Primária Líquida (PPL)

O índice de produtividade irá variar de um valor abaixo de 1 para sistemas de produção agrícola mais extrativos como as culturas anuais e poderá chegar até cerca de 50 para ecosssistemas naturais.

Assim, o Índice de Produtividade pode ser considerado um indicador para monitoramento dos impactos ambientais em microescala, pois indica um nível de monitoramento que é efetuado no próprio local, no agroecossistema.

Reuter et al. (1996) recomenda alguns indicadores de produtividade e performance para o monitoramento de microbacias na Austrália: \% produção potencial, produção de madeira, retorno econômico líquido por hectare, etc.

Deve ficar claro que os indicadores não são recomendados para todos os produtores rurais ou microbacias. Cada microbacia deve estabelecer seu conjunto de indicadores que estejam relacionados às características do local e que sejam capazes de propiciar uma real avaliação das condições e tendências de cada situação.

Na microbacia do Ribeirão São João alguns indicadores econômicos, como por exemplo, a produtividade da cana de açúcar e da pecuária de corte, o retorno econômico líquido por hectare, são promissores para fazer parte do conjunto de indicadores socioeconômicos propostos neste trabalho.

A melhoria da qualidade de vida da comunidade da microbacia, além de ser influenciada pelos aspectos econômicos e ambientais, também se relaciona à fatores 
culturais, como, no caso da microbacia estudada, a manutenção das festas locais, dos encontros para a reza, dos campeonatos de futebol, do leilão beneficente anual, que sempre ocorriam nas propriedades desta microbacia.

No contexto da microbacia, onde fortes interações acontecem entre os sistemas ecológicos, econômicos e sociais, o monitoramento socioeconômico somente terá sentido quando analisado de forma integrada ao monitoramento ambiental. Sob a ótica da sustentabilidade, a produção agrícola deve se desenvolver de forma compatível à preservação da natureza e a melhoria da qualidade de vida do homem do campo só ocorrerá quando o ambiente estiver saudável, o que provavelmente também acarretará produção rentável. 


\section{CONCLUSÕES}

O presente estudo, que pretendeu contribuir para que os planos de manejo integrado de microbacias pudessem incorporar uma aplicação prática do conhecimento atual sobre as zonas ripárias, teve sua hipótese testada e confirmada e seus objetivos atingidos, como demonstram as seguintes conclusões:

- A comparação, através da construção dos cenários convencionais e alternativos mostrou que a inclusão da zona ripária na determinação da adequação do uso do solo e dos riscos ambientais na microbacia resulta numa caracterização de riscos de degradação diferente, relativamente ao que é observado nos métodos convencionais que não a consideram, acarretando diferenças no planejamento sócio-ambiental da microbacia. Esta alteração pode induzir a tomadas de decisão incompletas para a proteção das áreas mais sensíveis e que representam maiores riscos para a saúde da microbacia.

- É importante identificar e delimitar a zona ripária e incluir o manejo do ecossistema ripário, que envolve sua dinâmica e sua vegetação característica, nos programas de manejo de microbacias hidrográficas, que têm como objetivo a busca de uma agricultura sustentável, a saúde da microbacia para, em última instância, estabelecer a manutenção dos recursos naturais e conseqüentemente, melhoria da qualidade de vida para a sociedade como um todo.

- A construção do cenário proposto ou hidrológico (com inclusão da zona ripária) vai ao encontro dos anseios da comunidade rural da microbacia do Ribeirão São João que priorizou, no diagnóstico e planejamento participativos, a proteção dos rios e nascentes e da mata ciliar desta microbacia.

- As relações entre o cenário que inclui a zona ripária e a legislação ambiental indicam que a largura da mata ciliar determinada pela lei (Áreas de Preservação 
Permanente) pode eventualmente ser apropriada para proteger os cursos d’ água, mas não é suficiente para resguardar áreas hidrologicamente sensíveis da microbacia. Para a proteção destas áreas existe a possibilidade da aplicação do Código Florestal (lei número 4.771/65) que trata sobre as reservas legais.

- Levando em conta as condições da microbacia, o cenário alternativo apresentado, assim como evidências baseadas na revisão de literatura, a proposta inclui o monitoramento sócio-ambiental da microbacia, parte intrínseca do processo do desenvolvimento sustentável, que deve levar em conta pelo menos os seguintes aspectos: monitoramento da água (balanço hídrico, a vazão, a concentração de nitrogênio e fósforo na água, a turbidez, a condutividade elétrica, a cor, os sólidos em suspensão, o oxigênio dissolvido e os macroinvertebrados aquáticos), do solo (indicadores visuais de degradação do solo, taxa de infiltração de água no solo, agregação e dispersão do solo, resistência do solo à penetração, densidade aparente e matéria orgânica, pH e o quociente metabólico), da integridade da paisagem (composição e padrão da cobertura do solo, posição das propriedades agrícolas com relação aos recursos hídricos e extensão e distribuição da zona ripária), da biodiversidade agroambiental (diversidade biológica) e monitoramento socioeconômico (produtividade da cana de açúcar e da pecuária de corte, o retorno econômico líquido por hectare e fatores culturais).

\subsection{Considerações Finais}

O desenvolvimento de uma proposta para o plano do manejo integrado da Microbacia do Ribeirão São João e do seu monitoramento socioeconômico e ambiental, envolvendo a identificação e a restauração da zona ripária como um instrumento deste manejo, pode servir como incentivo para iniciativas semelhantes em outras microbacias. Houve a preocupação de se desenvolver uma proposta que fosse possível de ser implementada pelos executores de planos de microbacias, com a utilização de recursos compatíveis aos que estão disponíveis a eles, para que a sua aceitação tanto por parte destes executores como pelos produtores rurais, pudesse resultar em trabalhos efetivos 
de manejo dos recursos hídricos, qualidade ambiental, conservação da biodiversidade e conseqüentemente em melhoria da qualidade de vida.

Com base nas conclusões deste trabalho, algumas recomendações são apresentadas a seguir.

A análise da distribuição da estrutura fundiária em relação à localização da zona ripária na microbacia pode identificar as áreas das propriedades rurais que se encontram em zona ripária Estas áreas poderiam ser protegidas pela Área de Preservação Permanente e pelo estabelecimento das reservas legais, que devem corresponder à $20 \%$ da área da propriedade ou, em média, da microbacia.

A porção da zona ripária que não estiver protegida pela legislação ambiental, por não estar localizada em Áreas de Preservação Permanente ou sem possibilidades de ser considerada reserva legal, deverá ter um manejo diferenciado de acordo com seu uso e ocupação.

Na microbacia as estradas rurais que representam risco de degradação do solo e da zona ripária, causando erosão, atravessando cursos d’ água, destruindo a vegetação, alterando os processos hidrológicos e conseqüentemente a dinâmica das florestas ribeirinhas, devem ser adequadas ou relocadas.

É imprescindível a participação da comunidade local no diagnóstico, no planejamento sócio-ambiental da microbacia e no desenvolvimento do plano de manejo integrado, pois apenas desta forma se faz legítima a implementação das ações planejadas. Este aspecto está inserido no cenário hidrológico.

A proposta para a Microbacia do Ribeirão São João, sob a ótica do cenário proposto, é a de implementar um programa de restauração florestal das áreas de preservação permanente, de estabelecimento das reservas legais, com base no paradigma contemporâneo da ecologia, tendo em vista a escala da microbacia ou da propriedade rural e de implantar um manejo conservacionista nas áreas agrícolas do entorno. Para as zonas ripárias com uso agrícola um manejo diferenciado deve ser aplicado.

A delimitação das áreas ripárias, através de outras pesquisas sob enfoque semelhante a deste trabalho, pode subsidiar as decisões para o planejamento da expansão da área urbana do município, da localização dos traçados de estradas rurais, para a 
determinação do local de depósitos de lixo e de captação de água para a população urbana ou para a comunidade rural, além do estabelecimento das reservas legais, etc.

Dentro do enfoque deste trabalho, seria interessante uma pesquisa que aprofundasse o conhecimento sobre o monitoramento sócio-ambiental de microbacias ocupadas com diversidade agrícola e por vários produtores rurais.

Para finalizar, este trabalho foi desenvolvido com a preocupação de contribuir com os esforços que muitos estão empreendendo para a preservação da natureza, não somente em solidariedade às futuras gerações, mas também por considerar o homem uma parte deste complexo sistema, devendo interagir com ele de forma harmônica e sustentável. 


\section{REFERÊNCIAS BIBLIOGRÁFICAS}

ALMEIDA, C. L. F.; OLIVEIRA, J. B.; PRADO, H. Levantamento pedológico semidetalhado do Estado de São Paulo. Campinas: Embrapa/S.A.A.-S.P., 1981. Quadrícula de Brotas, SF.22 - Z - B - III - 4, Escala 1 : 100.000.

ALTIERI, M. Agroecologia: bases científicas para uma agricultura sustentável. Guaíba: Agropecuária, 2002. 592 p.

ARCOVA, F. C. S. Balanço hídrico, características do deflúvio e calibragem de duas microbacias hidrográficas na Serra do Mar, SP. Piracicaba, 1996. 130 p. Dissertação (Mestrado) - Escola Superior de Agricultura “Luiz de Queiroz“, Universidade de São Paulo.

ARONSON, J.; FLORET, C.; FLOC’H, E.; OVALLE, C.; PONTANIER, R. Restoration and rehabilitation of degraded ecosystems in arid and semiarid lands. Restoration Ecology. v.1, n. 3, p. 168-186, 1993.

ÁVILA, H. A.; SANTOS, M. P. S. Cenários: o estudo de futuros alternativos. Ciência e Cultura. v. 41, n. 3. p. 241-249, mar 1989.

AZEVEDO, C. M. A. A decisão de preservar: a mata ripária do Jaguari-Mirim,SP. São Paulo: Annablume: FAPESP, 2000. 106 p.

BARBOSA, L. M. Considerações gerais e modelos de recuperação de formações ciliares. In: RODRIGUES, R. R.; LEITÃO FILHO, H. F. Matas Ciliares: Conservação e recuperação. São Paulo: EDUSP/ Fapesp, 2.000. cap. 15, p. 289-312. BERTOLINI, D.; DRUGOWICH, M. I.; LOMBARDI NETO, F.; BELLINAZZI JÚNIOR, R. Controle de erosão em estradas rurais. Campinas: Coordenadoria de Assistência Técnica Integral, 1993. 37 p. (Boletim Técnico, 207). 
BERTOLINI, D.; CARRARO, E.; LOMBARDI NETO,F.; LEPSCH, I. F.; MELLO, M. H. A.; DRUGOWICH, M. I.; PEDRO JÚNIOR, M. J.; BELLINAZZI JÚNIOR, R. Manual técnico de manejo e conservação do solo e água Potencialidades agrícolas das terras do Estado de São Paulo. Campinas: CATI, 1994. ( CATI. Boletim Técnico, 39).

BERTONI, J.; LOMBARDI NETO, F. Conservação do solo. São Paulo: Editora Ícone, 1990. 393p.

BERTONCINI, A. P. Estrutura e dinâmica de uma área perturbada na terra indígena Araribá, Avaí (SP): implicações para o manejo e a restauração florestal. Campinas, 2003. 162 p. Tese (Doutorado) - Universidade Estadual de Campinas

BLACK, P. E. Watershed Hidrology. New York: Lewis Publishers, 1996. 449 p.

BLINN, C. R.; KILGORE, N. A. Riparian management practices. Jornal of Forestry, v. 99, n. 8, p. 11-17, 2001.

BRANDÃO, D. Riscos de degradação dos recursos hídricos na bacia do Ribeirão Pinhal - Limeira (SP): Uma proposta metodológica. Campinas, 2001. 85 p. Dissertação (Mestrado) - Universidade Estadual de Campinas.

BROWN JÚNIOR., K. S. Insetos indicadores da história, composição, diversidade e integridade de matas ciliares tropicais. In: RODRIGUES, R. R.; LEITÃO FILHO, H. F. Matas Ciliares: Conservação e Recuperação. São Paulo: EDUSP/ Fapesp, 2.000. cap. 3, p. 223-232.

CÂMARA, C. D. Efeitos do corte raso do eucalipto sobre o balanço hídrico e a ciclagem de nutrientes em uma microbacia experimental. Piracicaba, 1999.

$87 \mathrm{p}$. Dissertação (Mestrado) - Escola Superior de Agricultura "Luiz de Queiroz" , Universidade de São Paulo.

CAMARGO, M.N.; KLAMT, E.; KAFFMAN, J.H.. Classificação de solo usados em levantamentos pedológicos no Brasil. Boletim Informativo da Sociedade Brasileira de Ciência do Solo, v. 12, n. 1, p. 11-33, 1987.

CASS, A.; MCKENZIE, N.; CRESSWELL, H. Physical indicators of soil health. In: WALKER, J.; REUTER, D. J. Indicators of catchment health: a technical perspective. Melbourne: CSIRO, 1996.cap. 7, p. 88 - 107. 
CHAER, G. M. Modelo para determinação de índice de qualidade do solo baseado em indicadores físicos, químicos e microbiológicos. Viçosa. 2001. 90 p. Dissertação (Mestrado) - Universidade Federal de Viçosa.

CHAPMAN, D.; KIMSTACH,V. The selection of water quality variables. In: CHAPMAN,D. (Ed.). Water Quality Assessments. A guide to the use of biota, sediments and water in environmental monitoring. London: Chapman \& Hall, 1992. cap. 3. p. 51-119.

COATES, J. F. Scenario planning. Technological Forecasting and Social Change. n. 65. p. 115-123, 2000.

CRANSTON, P. S.; FAIRWEATHER, P.; CLARKE, G. Biological indicators of water quality. In: WALKER, J.; REUTER, D. J. Indicators of catchment health: a technical perspective. Melbourne: CSIRO, 1996. cap. 1, p. 143 - 158.

CZAJKOWSKI, S. O Parque Nacional do Superagüi e alternativas para o planejamento de unidades de conservação de proteção integral. Rio Claro, 2004. 321 p. Tese (Doutorado) - Instituto de Geociências e Ciências Exatas.. Universidade Estadual Paulista “Júlio de Mesquita Filho”.

DERANI, C. A propriedade na constituição de 1988 e o conteúdo da "Função Social". Revista de Direito Ambiental, n. 27, p. 58-69, jul-set, 2002.

DONSELI, P. L.; VALÉRIO FILHO, M.; PINTO, S. A. F.; NOGUEIRA, F. P.; ROTTA, C. L.; LOMBARDI NETO, F. Técnicas de sensoriamento remoto aplicadas ao diagnóstico básico para planejamento e monitoramento de microbacias hidrográficas. In: LOMBARDI NETO, F.; CAMARGO, O. A. (Coord.). Microbacia do Córrego São Joaquim (Município de Pirassununga, SP)., Campinas : IAC, 1992, n. 29, p. 91-118.

DUMANSKI, J.; PIERI, C. Land quality indicators: research plan. Agriculture, Ecosystems \& Environment, v. 81, p. 93 - 102, 2000.

EL BASSAM, N.. Sustainable development in agriculture. global key issues. Natural Resources and Development. v.51, 1999. p. 39-57. 
EMMETT, B. A.; HUDSON, J. A.; COWARO, P. A.; REYNOLDS, B. The impact of a riparian wetland on stream water quality in a recently afforested upland catchment. Journal of Hydrology. v. 162, p. 337-353, 1994.

EMBRAPA - EMPRESA BRASILEIRA DE PESQUISA AGROPECUÁRIA, Sistema brasileiro de classificação de solos. Rio de Janeiro, RJ, 1999, 412 p.

EHLERS, E. Agricultura sustentável: Origens e perspectivas de um novo paradigma. 2. ed. Guaíba: Agropecuária, 1.999. 157 p.

FERNANDES, M. R. Vegetação ciliar no contexto de bacias hidrográficas In: SIMPÓSIO MATA CILIAR. CIÊNCIAS E TECNOLOGIA, Belo Horizonte, 1999, Anais. Belo Horizonte: CEMIG / UFLA, 1999. 235 p.

FERRETTI, A. R. O fomento florestal da CESP / Porto Primavera com propriedades da região de Assis-SP. Piracicaba. 2000. 156 p. Dissertação (Mestrado) - Escola Superior de Agricultura "Luiz de Queiroz“, Universidade de São Paulo.

FITZPATRICK, R. W. Morphological indicators of soil health. In: WALKER, J.; REUTER, D. J. Indicators of catchment health: a technical perspective. Melbourne: CSIRO, 1.996. cap. 6, p. 75 - 88.

GALJART, B. Difusão cultural, modernização e subdesenvolvimento. In: SZMRECSANYI, T.; QUEDA, O. (org.). Vida rural e mudança social: leituras básicas de sociologia rural. 3. ed. São Paulo: Nacional, 1979. p. 71-80.

GEILFUS, F.80 Herramientas para el desarrollo participativo: Diagnóstico, planificación, monitoreo, evaluación. Prochalate. El Salvador: IICA, 1997. 208p.

GLIESSMAN, S. R. Agroecologia: processos ecológicos em agricultura sustentável. 2. ed. Porto Alegre: Ed. Universidade/ UFRGS, 2.001. 653 p.

GRACIA, M. E. P. S. Planejamento agroambiental da microbacia do Córrego Soturninha, Arealva, SP. Campinas, 2001. 99 p. Dissertação (Mestrado) - Instituto Agronômico de Campinas.

GREGORI, S. V.; SWANSON, F.J.; McKEE, W. A .; CUMMINS, K. W. An ecosystem perspective of riparian zones. BioSciense, v. 41, n. 8, p. 540 - 551, 1991. 
HEWLETT, J. D.; HIBBERT, A. R. Factors affecting the response of small watersheds to precipitation in himid areas. In: INTERNATIONAL SYMPOSIUM OF FOREST HYDROLOGY. Oxford: Pergamon Press, 1967. p. 275-290.

HURNI, H. Assessment of sustainable land management (SLM). Agriculture, Ecosystems \& Environment, v. 81, p. 83 -92, 2000.

IBGE - INSTITUTO BRASILEIRO DE GEOGRAFIA E ESTATÍSTICA. Manual técnico da vegetação brasileira. 1992. 92 p. (Manuais Técnicos em Geociências, 1).

INSTITUTO DE PLANEJAMENTO E ECONOMIA AGRÍCOLA DE SANTA CATARINA (CEPA / SC). Avaliação do projeto Microbacias. Relatório de avaliação final. Resumo executivo.Governo do Estado de santa Catarina. Outubro, 1999. $52 \mathrm{p}$.

JONES, B.; WALKER, J.; RIITTERS, K. H.; WICKHAM, J. D.; NICOLL, C. Indicators of landscape integrity. In: WALKER, J.; REUTER, D. J. Indicators of catchment health: a technical perspective. Melbourne: CSIRO, 1.996.cap. 12, p. $155-168$.

JOLLY, J.; CAITCHEON, G.; DONNELLY, T.; HAFNER, S. Physical and chemical indicators of water quality. In: WALKER, J.; REUTER, D. J. Indicators of catchment health: a technical perspective. Melbourne: CSIRO, 1.996.cap. 10, p. 131- 141.

JOHNSON, W. C.; DIXON, M. D.; SIMONS, R.; JENSON, S.; LARSON, K. Mapping the response of riparian vegetation to possible flow reductions in the Snake River, Idaho. Geomorphology. v. 13. p. 159-173, 1995.

LAGROTTI, C. A. A. Planejamento agroambiental do município de Santo Antônio do Jardim, SP: Estudo de caso na microbacia hidrográfica do Córrego do Jardim. Campinas, 2000. 124 p. Tese (Doutorado) - Faculdade de Engenharia Agrícola Universidade Estadual de Campinas. 
LEONARDO, H. C. L. Indicadores de qualidade de solo e água para a avaliação do uso sustentável da microbacia hidrográfica do Rio Passo Cue, região oeste do Estado do Paraná. Piracicaba, 2003. 121 p. Dissertação (Mestrado) - Escola Superior de Agricultura "Luiz de Queiroz“, Universidade de São Paulo.

LEPSCH, I.F. Formação e conservação dos solos. São Paulo: Oficina de Textos, 2002. $178 \mathrm{p}$.

LEPSCH, I.F.; BELLINAZZI JR., R.; BERTOLINI, D.; ESPÍNDOLA, C.R. Manual para levantamento utilitário do meio físico e classificação de terras no sistema de capacidade de uso . $4^{\mathrm{a}}$. aproximação. Campinas: SBCS, 1991. 175 p.

LEPSCH, I.F.; BELLINAZZI JR., R.; BERTOLINI, D.; ESPÍNDOLA, C.R. Manual para levantamento utilitário do meio físico e classificação de terras no sistema de capacidade de uso . 4a. aproximação. Campinas: SBCS, 1983. 175p.

LIMA, W. P. O Impacto Ambiental do Eucalipto. 2 ed. São Paulo: EDUSP, 1993, $301 \mathrm{p}$.

LIMA, W. P. Hidrologia florestal aplicada ao manejo de bacias hidrográficas. Piracicaba, 1996. 315 p. (Apostila).

LIMA, W. P. A microbacia e o desenvolvimento sustentável. Ação Ambiental. v. 1, n. 3, p. 20 - 22, dez/1998 - jan/1999.

LIMA, W. P. Relações hidrológicas em matas ciliares. In: Henry, R.(Ed.). Ecótonos nas Interfaces dos Ecossistemas Aquáticos. São Carlos: Rima Editora, 2003. p. 301-312.

LIMA, W. P.; ZAKIA, M. J. B. Rede de monitoramento ambiental em microbacias: indicadores hidrológicos do manejo sustentável de plantações florestais. Piracicaba: IPEF, 1997. 26 p. (Relatório Anual)

LIMA, W. P.; ZAKIA, M. J. B. Hidrologia de matas ciliares. In: RODRIGUES, R. R.; LEITÃO FILHO, H. F. Matas ciliares: conservação e recuperação. São Paulo: EDUSP/ Fapesp, 2.000. cap. 3, p. 33-44.

LOMBARDI NETO, F.; PRUSKI, F.F.; TEIXEIRA, A de F. Sistema para o cálculo da erosividade da chuva para o Estado de São Paulo. (Compact disc). Viçosa. 2000. 
MALANSON, G. P. Riparian Landscapes. 2 ed. Cambridge: Great Britain at the University Press,. 1994, 296 p.

MARCONDES, M. A. P. Planejamento em manejo de bacias hidrográficas. In: CURSO INTERNACIONAL SOBRE MANEJO FLORESTAL EM BACIAS HIDROGRÁFICAS, 5., São Paulo, 1999. Resumos São Paulo: Instituto Florestal de São Paulo/JICA/ABC, 1999. 298 p.

MERRY, R. H. Chemical indicators of soil health. In: WALKER, J.; REUTER, D. J. Indicators of catchment health: a technical perspective. Melboune: CSIRO, 1.996.cap. 8, p. 109 - 119.

MILARÉ, E. Direito ambiental. doutrina-jurisprudência-glossário. 3. ed. São Paulo: Editora Revista dos Tribunais, 2004. 1024 p.

MONTGOMERY, R. D.; GRANT, G. E.; SULLIVAN, K. Watershed analysis as a framework for implementing ecosystem management. Water Resources Bulletin, v. 31, n. 3, p. 369 - 386, jun 1995.

NAIMAN, R. J.; DÉCAMPS, H. The ecology of interfaces: riparian zones. Annual Review Ecological System, v. 28, p. 621 - 658, 1997.

OMETTO, A. R. Discussão sobre os fatores ambientais impactados pelo setor sucroalcooleiro e a sertificação socioambiental. São Carlos, 2000. 255 p. Dissertação (Mestrado) - Escola de Engenharia de São Carlos - Universidade de São Paulo.

OTA-OFFICE OF TECHNOLOGY ASSESSMENT (Congress of USA). Beneath the Botton Line- Agricultural Aproaches to Reduce Agrichemical Contamination of Groundwater. Washington, DC. 1990, cap.5, p. 171-250: Farmer Decisionmaking and Technical Assistance.

PEREIRA, L. C. Sensibilidade ambiental e aptidão agrícola das terras: um estudo de caso na quadrícula de Ribeirão Preto, SP. Campinas, 2002. 160 p.Tese (Doutorado) Universidade Estadual de Campinas.

PICKETT, S.T.A.; OSTFELD, R. S. The shifiting paradigm in ecology. In: KNIGHT, R.L.; BATES, S.F.(Ed.). A New Century for Natural Resources Management. Washington: Island Press, 1995. p. 261-278. 
PROGRAMA DAS NAÇÕES UNIDAS PARA O DESENVOLVIMENTO-PNUD. Projeto Bra/94/016 (Área Temática: Agricultura Sustentável). Texto para o Workshop de Janeiro de 1.999. 116 p.

PROGRAMA ESTADUAL DE MICROBACIAS HIDROGRÁFICAS. Manual Técnico Governo do Estado de São Paulo - Secretaria de Agricultura e Abastecimento do Estado de São Paulo / CATI, 1997. 192 p.

QUIRINO, T.R.; IRIAS, L.J.M.; WRIGERT J.T.C. Impacto agroambiental. Perspectivas, problemas e prioridades. Rio de Janeiro: EMBRAPA, 1999. 183 p. REUTER, D.J.; MOORE, A. D.; KHANNA, P. K.; TENNANT, D.; McLEAN, G. D.;

FRENCH, R. J.; HINGSTON, F. J. Indicators of farm productivity and financial performance. In: WALKER, J.; REUTER, D. J. Indicators of catchment health: a technical perspective. Melbourne: CSIRO, 1.996.cap. 4, p. 47 - 66.

ROCHA, O.; PIRES, J. S. R.; SANTOS; J. E.. A bacia hidrográfica como unidade de estudo e planejamento. In: ESPÍNDOLA, E. L. G.; SILVA, J. S. V.; MARINELLI, C. E.; ABDON, M. M. In: A bacia hidrográfica do Rio Monjolinho: Uma abordagem ecossistêmica e a visão interdisciplinar. São Carlos: Editora Rima, 2000. cap 1 , p. $1-16$.

RODRIGUES, R. R. A vegetação de Piracicaba e municípios do entorno. Circular Técnica IPEF, n. 189,ago., 1999. 17 p.

RODRIGUES, R. R.; GANDOLFI, S. Restauração de florestas tropicais: Subsídios para uma definição metodológica e indicadores de avaliação e monitoramento. In: DIAS, L.E.; MELLO, J.W.V. (Ed.). Recuperação de Áreas degradadas. Viçosa: UFV/SOBRADE, 1998. p. 203-215.

RODRIGUES, R. R.; GANDOLFI, S. Conceitos, tendências e ações para a recuperação de florestas ciliares. In: RODRIGUES, R. R.; LEITÃO FILHO, H. F. Matas ciliares: Conservação e recuperação. São Paulo: Editora da Universidade de São Paulo: Fapesp, 2.000. cap. 15.1, p. 235-247. 
RODRIGUES, R. R.; NAVE, A . G. Heterogeneidade florística das matas ciliares. In: RODRIGUES, R. R.; LEITÃO FILHO, H. F. Matas ciliares: Conservação e recuperação. São Paulo: Editora da Universidade de São Paulo Fapesp, 2.000. cap. 4, p. 45-71.

RODRIGUES, R. R.; SHEPHERD, G. J. Fatores condicionantes da vegetação Ciliar. In: RODRIGUES, R. R.; LEITÃO FILHO, H. F. Matas Ciliares: Conservação e recuperação. São Paulo: Editora da Universidade de São Paulo: Fapesp, 2.000. cap. 6.2, p. 101- 107.

RODRIGUES, R. R.; GANDOLFI, S.; NAVE, A G., FARAH, F. T., NOVAES, E.; PIROMAL, R. A. S. Programa de adequação ambiental das áreas agrícolas da Cia Açucareira Vale do Rosário. Piracicaba : USP/ESALQ/Depto Ciências Biológicas, 2001.250 p.

SANTOS, R. F. Princípios de planejamento ambiental. Campinas, 2003. 247 p. Tese (Livre Docência). Faculdade de Engenharia Civil, Universidade Estadual de Campinas.

SETZER, J. Atlas climático e ecológico do Estado de São Paulo. Comissão Interestadual da Bacia do Paraná-Uruguai e Centrais Elétricas do Estado de São Paulo,1966. 61p.

SMITH, C.; THWAITES, R. ForesTIM: Evaluating plantation forest land management by identifying unsustainable practices. Australian Forestry. $\quad$ v. 61, n. 2, p. $89-$ 102, 1998.

SOUZA, A. L. L. Meio ambiente e desenvolvimento sustentável: Uma reflexão crítica. Belém: FCAP, Serviço de documentação e informação, 1996. 50 p.

SPAROVEK, G.; RANIERI, S. B. L.; GASSNER, A.; DE MARIA, I. C.; SCHNUG, E.; SANTOS, R. F.; JOUBERT, A. A conceptual framework for the definition of the optimal width of riparian forests. Agriculture, Ecosystems \& Environment, v. 90. p. 169-175, 2002.

THAME, A. C. M. (Org.). Comitês de bacias hidrográficas. Uma revolução conceitual. São Paulo : IQUAL Editora, 2002. 150 p. 
VALENTE, O. F. Manejo de bacias hidrográficas. Ação Ambiental. v. 1, n. 3, p. 05 - 06, dez/1998 - jan / 1999.

VALERIANO, M. M. Estimativa de variáveis topográficas por geoprocessamento para modelagem da perda de solo. Rio Claro, SP, 1999. 172p. Tese (Doutorado). Universidade Estadual Paulista “Júlio de Mesquita Filho”.

WALKER, J.; REUTER, D. J. Key indicators to asses farm and catchment health. In: WALKER, J.; REUTER, D. J. Indicators of catchment health: a technical perspective. Melbourne:CSIRO, 1.996. cap. 2, p. 21 - 33.

WALKER, J.; ALEXANDER, D.; IRONS, C.; JONES, B.; PENRIDGE, H.; RAPPORT, D. Catchment health indicators: as overview. In: WALKER, J.; REUTER, D. J. Indicators of catchment health: a technical perspective. Melbourne: CSIRO, 1.996. cap. 1, p. 3 - 18.

WALMSLEY, J. J. Framework for measuring sustainable development in catchment systems. Environmental Management, v. 29, n. 2, p. 195-206, 2002.

WILSON, I. From scenarios thinking to strategic action. Technological Forecasting and Social Change, n. 65, p. 23-29, 2000.

WOLLENBERG, E.; EDMUNDS, D.; BUCK, L. Using scenarios to make decisions about the future: antecipatory learning for adaptive co-management of community forests. Landscape and Urban Planning. n. 47, p. 65-77, 2000.

ZAKIA, M. J .B. Identificação e caracterização da zona ripária em uma microbacia experimental: implicações no manejo de bacias hidrográficas e na recomposição florestal.São Carlos, 1998. 98 p. Tese (Doutorado) - Escola de Engenharia de São Carlos - Universidade de São Paulo. 